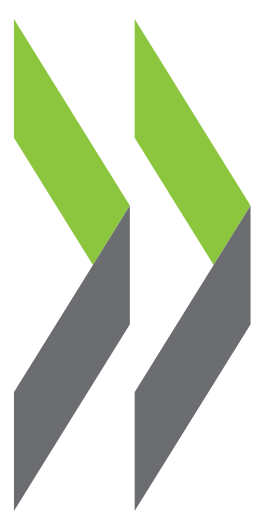

OECD Studies on SMEs and Entrepreneurship

\title{
Entrepreneurship Policies through a Gender Lens
}



OECD Studies on SMEs and Entrepreneurship

\section{Entrepreneurship Policies through a Gender Lens}


This work is published under the responsibility of the Secretary-General of the OECD. The opinions expressed and arguments employed herein do not necessarily reflect the official views of OECD member countries.

This document, as well as any data and map included herein, are without prejudice to the status of or sovereignty over any territory, to the delimitation of international frontiers and boundaries and to the name of any territory, city or area.

The statistical data for Israel are supplied by and under the responsibility of the relevant Israeli authorities. The use of such data by the OECD is without prejudice to the status of the Golan Heights, East Jerusalem and Israeli settlements in the West Bank under the terms of international law.

Note by Turkey

The information in this document with reference to "Cyprus" relates to the southern part of the Island. There is no single authority representing both Turkish and Greek Cypriot people on the Island. Turkey recognises the Turkish Republic of Northern Cyprus (TRNC). Until a lasting and equitable solution is found within the context of the United Nations, Turkey shall preserve its position concerning the "Cyprus issue".

Note by all the European Union Member States of the OECD and the European Union

The Republic of Cyprus is recognised by all members of the United Nations with the exception of Turkey. The information in this document relates to the area under the effective control of the Government of the Republic of Cyprus.

Please cite this publication as:

OECD (2021), Entrepreneurship Policies through a Gender Lens, OECD Studies on SMEs and Entrepreneurship, OECD

Publishing, Paris, https://doi.org/10.1787/71c8f9c9-en.

ISBN 978-92-64-56525-8 (print)

ISBN 978-92-64-50755-5 (pdf)

OECD Studies on SMEs and Entrepreneurship

ISSN 2078-0982 (print)

ISSN 2078-0990 (online)

Photo credits: Cover @ Gerd Altmann/Pixabay. 


\section{Foreword}

This report aims to provide momentum on discussions about the design, delivery, scope and effectiveness of women-focused entrepreneurship policies and the gendered implications of mainstream policies and programmes. This work also identifies limitations with current policy approaches and points the way to more effective policy.

The report highlights long-standing issues that policy makers need to address to better support and promote women's entrepreneurship. Many of these issues have been underlined and exacerbated by the COVID-19 pandemic, which erupted during the preparation of this report. Governments have attempted to contain the spread of the COVID-19 virus with measures that have restricted economic and social activities, with severe consequences for many entrepreneurs. Women entrepreneurs have been hit harder than other entrepreneurs, in part reflecting the fact that women entrepreneurs are more likely to be operating businesses in the service sectors. Women are also disproportionately impacted by isolating at home with family measures. In addition, they often have greater difficulties accessing emergency liquidity measures because their businesses do not meet threshold criteria or are involved in ineligible activities. They are also less likely to use external finance, so government credit extensions and suspensions of payments to entrepreneurs have had less impact. Collectively, these issues threaten to reverse the progress that has been made in closing the gender gap in entrepreneurship over the past several decades.

The report presents a collection of 27 policy insight notes on women's entrepreneurship policy that were prepared by members of the Global Women's Entrepreneurship Policy Research Project (Global WEP www.globalwep.org) - a network of established researchers from over 30 counties - in collaboration with the OECD. This partnership leverages the knowledge, experience and perspectives of the individual country-based scholars who prepared the collection of policy insight notes. While the collection of policy insight notes has been reviewed by the OECD Working Party on SMEs and Entrepreneurship, the notes were prepared by independent researchers and do not necessarily reflect the views of the OECD or its Member Countries. 


\section{Acknowledgements}

This report was developed in the Centre for Entrepreneurship, SMEs, Regions and Cities (CFE) of the Organisation for Economic Co-operation and Development (OECD) led by Lamia Kamal-Chaoui, Director.

The report is the result of a collaboration between the OECD CFE and the Global Women's Entrepreneurship Policy Research Project (Global WEP), which is a network of established researchers from over 30 counties. This initiative was led by Jonathan Potter (Head of the Entrepreneurship Policy and Analysis Unit) of the OECD CFE and Colette Henry - Chair of Global WEP - (Dundalk Institute of Technology, Ireland and Griffith University, Queensland, Australia), Barbara Orser (University of Ottawa, Canada), and Susan Coleman (University of Hartford, United States) of the Global WEP Project.

The report was edited by David Halabisky (Policy Analyst) and Jonathan Potter (Head of Unit) of the Entrepreneurship Policy and Analysis Unit of the SME and Entrepreneurship Division of the OECD CFE. Cynthia Lavison (Policy Analyst), also of the OECD CFE, supported the preparation of this report by reviewing draft policy insight notes. Edits were also made by the Global WEP Executive Team - Colette Henry, Barbara Orser and Susan Coleman.

Part 1 of this report contains two chapters. Chapter 1 was drafted by Colette Henry, Barbara Orser, and Susan Coleman, with inputs by David Halabisky. Chapter 2 was drafted by David Halabisky.

Part 2 is comprised of policy insight notes on different aspects of women's entrepreneurship policy and includes introductions for each policy theme. The notes were drafted by the following members of the Global WEP network: Australia: Patrice Braun (Federation University Australia), Naomi Birdthistle (Griffith University) and Antoinette Flynn (University of Limerick); Canada: Barbara Orser (University of Ottawa); Czech Republic: Alena Křižková Pospíšilová (Institute of Sociology, Czech Academy of Sciences) and Marie Pospíšilová (Institute of Sociology, Czech Academy of Sciences); Denmark: Helle Neergaard (Aarhus University); Ethiopia: Atsede Tesfaye (Addis Ababa University); Germany: Friederike Welter (University Siegen and IfM Bonn); India: Roshni Narendran (University of Tasmania); Iran: Nastaran SimarasI (California State Polytechnic University - Pomona) and Vahid Makizadeh (University of Hormozgan); Ireland: Colette Henry (Dundalk Institute of Technology and Griffith University); Italy: Sara Poggesi (University of Rome Tor Vergata), Michela Mari (University of Rome Tor Vergata) and Luisa De Vita (Sapienza University of Rome); Kenya: Anne W. Kamau (University of Nairobi) and Winnie V. Mitullah (University of Nairobi); Mexico: Rosa Nelly Trevinyo-Rodriguez (Trevinyo-Rodriguez \& Asociados); New Zealand: Anne de Bruin (Massey University) and Kate V. Lewis (Newcastle University); Northern Ireland, UK: Joan Ballantine (Ulster University) and Pauric McGowan (Ulster University); Norway: Lene Foss (UiT - The Arctic University of Norway and Jönköping University, Sweden); Pakistan: Shumaila Yousafzai (Cardiff University) and Shandana Sheikh (Cardiff University); Palestinian Authority: Grace Khoury (Birzeit University); Poland: Ewa Lisowska (Warsaw School of Economics); Scotland, UK: Anne F. Meikle; South Africa: Bridget Irene (Coventry University); Spain: Maria Cristina Diaz Garcia (University of CastillaLa Mancha); Sri Lanka: Nadeera Ranabahu (University of Canterbury); Sweden: Helene Ahl (Jönköping University); Tanzania: Dina Modestus Nziku (University of the West of Scotland) and Cynthia Forson (Lancaster University Ghana); Turkey: Duygu Uygur (Istanbul Bilgi University) and Elif Bezal Kahraman; United Kingdom: Helen Lawton Smith (Birkbeck, University of London) and Tim Vorley (Oxford Brookes 
University); and United States: Susan Coleman (University of Hartford). The drafting of the policy insight notes in this report was led by Colette Henry, Barbara Orser and Susan Coleman of Global WEP, under the guidance of Jonathan Potter and David Halabisky.

Each chapter in Part 2 contains a short introductory text prepared by Colette Henry, Barbara Orser, Susan Coleman and David Halabisky.

The editors gratefully acknowledge feedback received from Céline Kauffman (Head) and Lucia Cusmano (Deputy Head) of the SME and Entrepreneurship Division, CFE, OECD, as well as support from Pilar Philip and François Iglesias of the OECD CFE during the publication process.

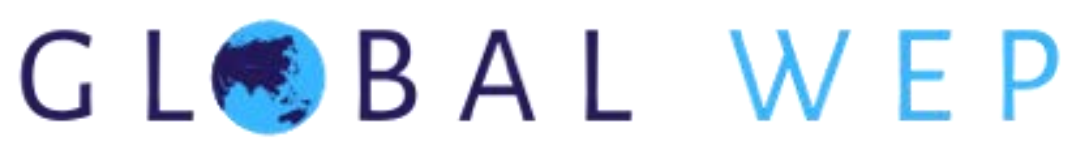

WOMEN'S ENTREPRENEURSHIP POLICY RESEARCH 


\section{Table of contents}

Foreword

$\begin{array}{ll}\text { Acknowledgements } & 4\end{array}$

$\begin{array}{ll}\text { Reader's guide } & 9\end{array}$

$\begin{array}{ll}\text { Executive summary } & 11\end{array}$

$\begin{array}{ll}\text { Part I State of women's entrepreneurship } & 13\end{array}$

1 Key findings and recommendations 14

In Brief $\quad 15$

The gender gap in entrepreneurship has reduced over the past 20 years $\quad 17$

COVID-19 risks reversing gains in women's entrepreneurship $\quad 17$

Traditional gender roles exert negative influences on women's entrepreneurship 17

Women's entrepreneurship policies are well-established in many countries $\quad 18$

Women's entrepreneurship policy frameworks are needed to underpin individual policy actions 18

Women's entrepreneurship interventions must be contextualised 18

More effective implementation of policies is needed to achieve policy objectives $\quad 19$

Greater efforts are needed to address gender gaps in entrepreneurship skills $\quad 19$

Greater use of dedicated measures is needed to address gender gaps in access to financing 19

$\begin{array}{ll}\text { References } & 20\end{array}$

2 The state of women's entrepreneurship 21

The gender gap has been closing among solo entrepreneurs... 22

...but the gender gap was growing among self-employed with employees $\quad 23$

COVID-19 is exacerbating gender gaps in entrepreneurship $\quad 24$

Women often have different motivations and intentions in entrepreneurship than men $\quad 27$

Women entrepreneurs face a range of subtle barriers to start-up $\quad 28$

Policy can play an important role in supporting women's entrepreneurship 32

References $\quad 33$

$\begin{array}{ll}\text { Part II International policy insight notes } & 35\end{array}$

3 Fostering a gender-sensitive entrepreneurship culture 36

Creating a positive image of women entrepreneurs $\quad 37$

The role of public policy $\quad 37$

Lessons from the policy cases $\quad 38$ 
$\begin{array}{ll}\text { Australia } & 40\end{array}$

$\begin{array}{ll}\text { Germany } & 44\end{array}$

$\begin{array}{ll}\text { India } & 47\end{array}$

$\begin{array}{ll}\text { Iran } & 51\end{array}$

Turkey $\quad 54$

$\begin{array}{ll}\text { United Kingdom } & 58\end{array}$

4 Strengthening the design and delivery of women's entrepreneurship support 61

Balancing mainstream and dedicated support $\quad 62$

Defining objectives and targets $\quad 62$

$\begin{array}{ll}\text { Increasing programme outreach and accessibility } & 63\end{array}$

Lessons from the policy cases $\quad 63$

$\begin{array}{ll}\text { Canada } & 65\end{array}$

Czech Republic $\quad 70$

$\begin{array}{ll}\text { New Zealand } & 76\end{array}$

Northern Ireland, United Kingdom $\quad 79$

$\begin{array}{ll}\text { Sweden } & 82\end{array}$

5 Building entrepreneurship skills for women 85

The need for gender-based entrepreneurship education and training 86

The role of public policy $\quad 86$

Lessons from the policy cases $\quad 86$

$\begin{array}{lr}\text { Denmark } & 89\end{array}$

$\begin{array}{ll}\text { Poland } & 93\end{array}$

$\begin{array}{ll}\text { Tanzania } & 96\end{array}$

6 Facilitating women entrepreneurs' access to financial capital 101

There are barriers to finance on both the supply- and demand-side 102

The role of public policy 102

Lessons from the policy cases 103

$\begin{array}{ll}\text { Ethiopia } & 105\end{array}$

Ireland 108

Italy 113

Mexico 117

Norway 122

South Africa $\quad 127$

Spain 130

$\begin{array}{ll}\text { United States } & 135\end{array}$

7 Supporting networks for women entrepreneurs 139

The importance of entrepreneurship networks and supportive ecosystems 140

The role of public policy 141

Lessons from the policy cases $\quad 141$

Palestinian Authority 143

Scotland, United Kingdom 147

8 Building a supportive regulatory environment for women entrepreneurs 151

Supporting women's entrepreneurship through the regulatory environment 152

The role of public policy 152

Lessons from the policy cases 153 
\begin{tabular}{l} 
Kenya \\
\hline
\end{tabular}

$\begin{array}{lr}\text { Pakistan } & 158\end{array}$

$\begin{array}{lr}\text { Sri Lanka } & 162\end{array}$

Annex A. About Global WEP 165

\section{FIGURES}

Figure 2.1. The gender gap in self-employment is closing in most countries 22

Figure 2.2. Women entrepreneurs are less likely to be employers and the gender gap is growing 24

Figure 2.3. Female-operated businesses have been more likely to close during the COVID-19 pandemic 25

Figure 2.4. Women are over-represented in the sectors hardest hit by COVID-19 25

Figure 2.5. Female business leaders have been more likely to assume household responsibilities during the COVID-19 pandemic

Figure 2.6. There is a larger gender gap in early-stage entrepreneurship 27

Figure 2.7. High-growth expectations 28

Figure 2.8. Fear of failure as a barrier to business start-up 30

Figure 2.9. Entrepreneurial skills 31

\section{TABLES}

Table 1. Overview of the focus of the women's entrepreneurship policy insight notes

\section{Follow OECD Publications on:}

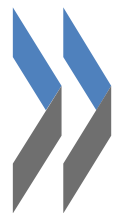

http://twitter.com/OECD_Pubs

f http://www.facebook.com/OECDPublications

in. http://www.linkedin.com/groups/OECD-Publications-4645871

- http://www.youtube.com/oecdilibrary 


\section{Reader's guide}

\section{What will I learn from this report?}

This report contains a collection of 27 policy insight notes on long-running policy issues in women's entrepreneurship support. Many of these issues have become even more relevant as the COVID-19 pandemic threatens to set women's entrepreneurship back 20 years. The notes cover a range of policy challenges - including in relation to formal and informal institutions, access to finance, access to skills and policy design - and policy instruments that can be used to address them. The notes underline core principles and good practices to follow in designing and implementing policies.

This report also offers an overview of the state of women's entrepreneurship in OECD countries and beyond, using gender-disaggregated indicators on business creation, self-employment and barriers to business start-up, sustainability and growth. These indicators illustrate gender gaps in entrepreneurship, not only in activity rates but also in the proportion of entrepreneurs who create jobs for others. Persistent gender gaps call on public policy to continue to address gender inequalities in entrepreneurship.

Overall, the report provides an important source of insights to assist policy makers seeking to strengthen holistic interventions in support of women's entrepreneurship, and to encourage and facilitate peer learning across countries.

\section{How can I read this report?}

While this report can be read linearly, it is designed to also be read in sections, allowing readers to easily identify themes and issues that are of most interest to them, and to access relevant policy insight notes.

The report is structured in two parts. Part I contains two chapters, with the first presenting the main policy messages that emerge from the collection of policy insight notes. Chapter 2 provides an overview of the current state of women's entrepreneurship internationally, including how activity rates have changed over the past 20 years. It also presents differences in barriers to entrepreneurship by gender across countries.

Part II of the report is composed of a collection of 27 policy insight notes from OECD Member Countries and beyond. These notes are organised around the six pillars of the OECD-EU Better Entrepreneurship Policy Tool (www.betterentrepreneurship.eu), which is designed to support policy makers in the design of their policies for inclusive entrepreneurship (see Table 1). 
Table 1. Overview of the focus of the women's entrepreneurship policy insight notes

\begin{tabular}{|c|c|c|}
\hline Policy area & Note & Policy issue \\
\hline \multirow{6}{*}{$\begin{array}{l}\text { 1. Fostering an inclusive } \\
\text { entrepreneurial culture }\end{array}$} & Australia & Building the pipeline of women entrepreneurs \\
\hline & Germany & How to change traditional gender role models \\
\hline & India & Women entrepreneurs' personal safety \\
\hline & Iran & The institutional environment \\
\hline & Turkey & Culture, human capital and education \\
\hline & United Kingdom & Addressing under-representation of women in innovation \\
\hline \multirow{5}{*}{$\begin{array}{l}\text { 2. Strengthening the design } \\
\text { and delivery of women's } \\
\text { entrepreneurship support }\end{array}$} & Canada & Operationalising the Women Entrepreneurship Strategy \\
\hline & Czech Republic & Lack of support for women entrepreneurs \\
\hline & New Zealand & Is there a need for a gendered entrepreneurship policy? \\
\hline & Northern Ireland (UK) & The absence of a dedicated women's entrepreneurship policy \\
\hline & Sweden & Private rather than public welfare delivery does not help women or their businesses \\
\hline \multirow{3}{*}{$\begin{array}{l}\text { 3. Building entrepreneurship } \\
\text { skills and capacities for } \\
\text { women entrepreneurs }\end{array}$} & Denmark & Education, self-employment, dual roles and political priorities \\
\hline & Poland & Skills development, mentoring and networking \\
\hline & Tanzania & Education, training and entrepreneurial skills development \\
\hline \multirow{8}{*}{$\begin{array}{l}\text { 4. Facilitating access to } \\
\text { business finance for women } \\
\text { entrepreneurs }\end{array}$} & Ethiopia & Access to finance \\
\hline & Ireland & Access to finance \\
\hline & Italy & Financing women-owned firms \\
\hline & Mexico & Financial literacy and financial exclusion \\
\hline & Norway & Access to finance \\
\hline & South Africa & Access to finance \\
\hline & Spain & Access to finance \\
\hline & United States & Access to financial capital \\
\hline \multirow{2}{*}{$\begin{array}{l}\text { 5. Expanding networks for } \\
\text { women entrepreneurs }\end{array}$} & Palestinian Authority & Networks and mentoring \\
\hline & Scotland (UK) & Creating a gender-focused business support eco-system \\
\hline \multirow{3}{*}{$\begin{array}{l}\text { 6. Building a supportive } \\
\text { regulatory environment for } \\
\text { women entrepreneurs }\end{array}$} & Kenya & Access to social protection \\
\hline & Pakistan & Weak regulatory institutions \\
\hline & Sri Lanka & Business environment and support \\
\hline
\end{tabular}

\section{How was this report developed?}

The report is the result of a collaboration between the OECD Centre for Entrepreneurship, SMEs, Regions and Cities (CFE) and the Global Women's Entrepreneurship Policy Research Project (Global WEP). The concept of the report was presented and discussed at the annual meeting of the Global WEP project in Birmingham, United Kingdom in November 2018. Network members were invited to prepare short women's entrepreneurship policy insight notes on a topical issue.

Each note was developed by researchers that work on entrepreneurship policy issues according to a common template provided by the OECD CFE. The policy insight notes subsequently went through a twostage review process. First, the notes were peer-reviewed within the Global WEP network and then by the OECD CFE. The notes were revised and are presented here around the framework developed by the OECD CFE for the OECD-EU Better Entrepreneurship Policy Tool. 


\section{Executive summary}

\section{There are persistent gender gaps in entrepreneurship}

\section{Women are less likely to be entrepreneurs than men...}

Women, overall, are less involved in entrepreneurship than men. For example, women in OECD countries are 1.5 times less likely than men to be working on a business start-up. This gap varies greatly across countries, however, there is no OECD country where women are more active than men in business creation. The gender gap - when measured by the share of women and men who are self-employed - had reduced between 2000 and 2019 in 25 out of 31 OECD countries, where data are available (covering a period before the onset of the COVID-19 pandemic). This progress reflected factors such as improving framework conditions and women's entrepreneurship policies, as well as a slight decline in the share of men who are self-employed.

\section{... and tend to operate smaller and less dynamic businesses}

Women entrepreneurs tend to operate different types of businesses than men. Women-operated businesses are most likely to operate in personal service sectors, retail, tourism, health care and education. Moreover, women entrepreneurs tend to operate businesses that are less likely than those operated by male entrepreneurs to create jobs for others, export, or to introduce new products and services.

\section{These gender gaps are caused by many inter-related factors...}

The explanations for these gaps are not clear-cut. Some of the differences are due to institutional barriers that constrain women in entrepreneurship. These include family and tax policies that discourage labour market participation and entrepreneurship, and negative social attitudes towards women's entrepreneurship. There are market failures, for example in financial markets, which make it more difficult for women to access the finance needed to be successful in business creation and self-employment. Furthermore, public policy initiatives aimed at addressing barriers to entrepreneurship may not be effective at reaching potential women entrepreneurs. However, it is important not to overlook the element of personal choice, since women often have different motivations and intentions in entrepreneurship compared to men.

\section{....and the COVID-19 pandemic risks undoing progress made in closing the gender gap}

The evidence suggests that women entrepreneurs have been hit harder by the COVID-19 pandemic. The impacts, in large part, reflect the sectors in which they operate and disproportionately higher burdens managing domestic responsibilities, such as home-schooling, during confinement periods. Other factors were at play. Initial emergency policy support measures for entrepreneurs and small business owners were gender biased, such that women had greater difficulties accessing relief. The combination of greater impacts on women-owned businesses and uneven access to COVID-19 support measures may result in the pandemic erasing much of the progress made in strengthening women's entrepreneurship over recent years. 


\section{Governments are using a wide range of instruments to encourage and support women's entrepreneurship but work remains}

The policy insight notes in this report argue that mainstream entrepreneurship policies and programmes are not gender-neutral. Explicit approaches are needed to address barriers to entrepreneurship that are experienced differentially by men and women, and to ensure that women have equal access to policy support aimed at entrepreneurs.

To an extent, this reality is recognised by the wide range of dedicated policy interventions for women's entrepreneurship that have been put in place internationally across many contexts. The interventions address barriers in the areas of entrepreneurship culture, entrepreneurship skills, access to finance, entrepreneurship networks and ecosystems, and regulatory institutions, as well as approaches to designing and delivering policies to achieve gender equality. These approaches illustrate the dynamic nature of women's entrepreneurship policy, as well as the gains that are being made as policy makers recognise the needs and contributions of women entrepreneurs.

However, women's enterprise policy initiatives are often fragile - time-limited, small-scale, sparse, symptom-oriented - and not sufficiently underpinned by a genuine vision and framework for women's entrepreneurship. To address these limitations, there is a need to increase awareness and knowledge about policies that engage and support women entrepreneurs within entrepreneurial ecosystems. Adherence to gender-blind entrepreneurship policies will be ineffective in achieving the benefits to be had from truly stimulating equal opportunities in entrepreneurship.

There are three main priorities for further policy development:

\section{Overarching policy frameworks for women's entrepreneurship need to be introduced}

In some countries, policy frameworks for women's entrepreneurship are well-developed and women's entrepreneurship programmes work effectively towards the global objectives and priorities set out in these frameworks. However, in other countries, women's entrepreneurship policies are incomplete or ineffective, often because the programmes are not consistent with global policy objectives. Governments should do more to strengthen policy frameworks for women's entrepreneurship. They also need to dedicate greater resources to ensure that programmes are informed by frameworks and are sustainable in the long-term.

\section{Women's entrepreneurship policy interventions must reflect context}

In some countries, policy frameworks for women's entrepreneurship are well-developed and women's entrepreneurship programmes work effectively towards the global objectives and priorities set out in these frameworks. However, in other countries, women's entrepreneurship policies are incomplete or ineffective, often because the programmes are not consistent with global policy objectives. Governments should do more to strengthen policy frameworks for women's entrepreneurship. They also need to dedicate greater resources to ensure that programmes are informed by frameworks and are sustainable in the long-term.

\section{More evaluation evidence is needed as a foundation for scaling policy initiatives}

A wide variety of policy instruments and delivery approaches have been put in place in many countries. A key challenge is to assess the effectiveness of these approaches in different situations and different combinations and to scale and transfer the most effective approaches. More evidence is needed on the effectiveness of women's entrepreneurship supports in different contexts. This includes, for example the impacts of measures for training and mentoring, financing, and the role of measures that influence underlying institutional conditions. Information is also needed on the extent to which measures need to be applied as packages. The lack of evaluation evidence represents a lost opportunity to learn from high impact policy interventions and may lend to the vulnerability of women's enterprise programme funding. 


\section{Part I State of women's entrepreneurship}




\section{Key findings and recommendations}

There has been gradual progress in closing the gender gap in entrepreneurship during the last 20 years. However, the COVID-19 pandemic is having a catastrophic impact on entrepreneurs and small businesses. The gender-regressive impacts are evident in women's entrepreneurial activities. Sectors where women entrepreneurs are concentrated have been hit hardest and many women entrepreneurs struggle to access emergency support measures. Reinforced policy action is required to support women entrepreneurs. This chapter summarises the internationally-comparable indicators presented in the report on the state of women's entrepreneurship across the globe, and the main policy messages contained in the policy insight notes. 


\section{In Brief}

\section{Gender gaps in entrepreneurship persist and risk growing due to COVID-19}

Women in OECD countries are $\mathbf{1 . 5}$ times less likely than men to be working on a business start-up.

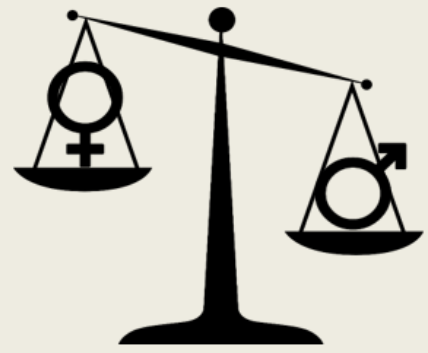

$5.7 \% \quad$ vs. $\quad 8.4 \%$

of people are actively working on creating a business.
Women entrepreneurs in OECD countries are 1.5 times less likely than men to employ others.

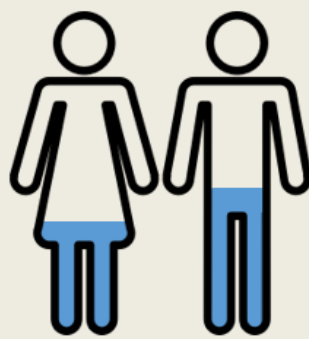

$24 \%$ vs. $34 \%$

of the self-employed have at least one employee.

Gender gap (\%) in early-stage entrepreneurship rates

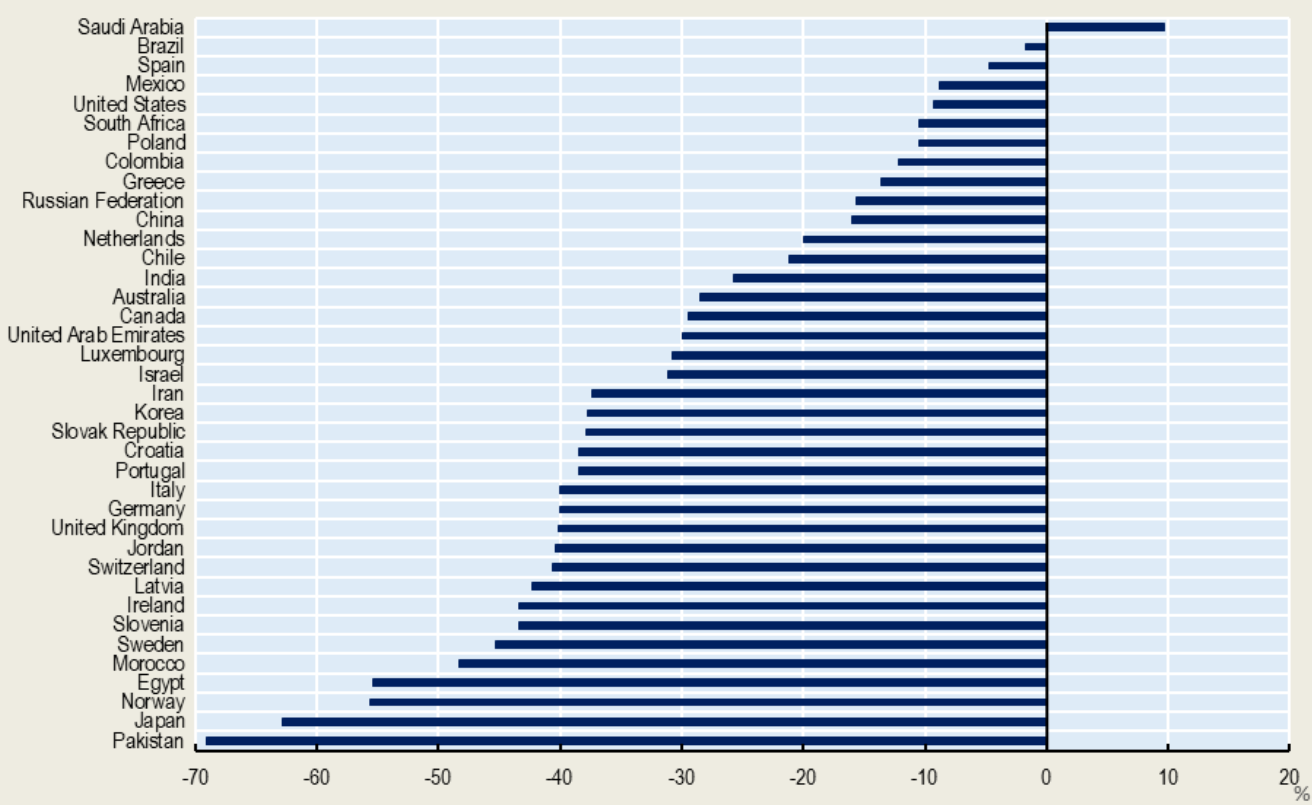

Among OECD countries, compared to more than half of men surveyed, only 4 out of 10 women reported having the skills needed to start a business.

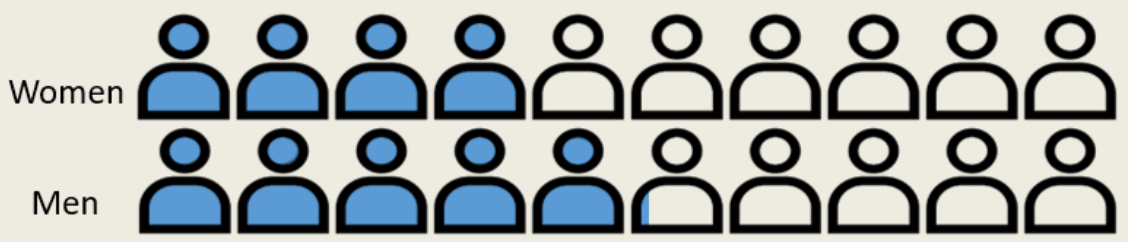




\section{Women's entrepreneurship policy needs to be better contextualised}

The gender gap in entrepreneurship has been closing slowly. Between 2000 and 2019, the gender gap in entrepreneurship, as measured by self-employment, shrank in 25 out of 31 OECD countries where data were available. This is an important achievement. It must also be acknowledged that this is due partly to a decline in the share of men who were self-employed.

Progress has been slower in closing other gender gaps associated with entrepreneurship. For example, the gap between the share of men and women entrepreneurs who employ others has grown slightly since 2000. In addition, gaps remain in entrepreneurship skills and access to finance.

The COVID-19 pandemic has hit women entrepreneurs harder than men entrepreneurs. Women entrepreneurs are more likely to be operating businesses in sectors that have been disproportionally impacted by containment and social-distancing measures, including personal services, retail and tourism. In addition, women entrepreneurs have faced greater challenges accessing emergency relief due to thresholds and other qualification criteria. The pandemic presents a risk of undoing progress in closing gender gaps and advancing women's entrepreneurship.

The policy insight notes in this report illustrate a wide range of policy approaches, challenges and contexts. When read together, a number of lessons for policy makers can be drawn:

- To close gender gaps in entrepreneurship, greater efforts are needed by governments to address underpinning biases in society and the labour market. Gender roles can have a strong and often negative influence on women's entrepreneurship.

- Strong framework conditions for entrepreneurship are a prerequisite for women's entrepreneurship policy.

- Women's entrepreneurship policies need a strong commitment and investment. Even when there is a solid policy framework for women's entrepreneurship, a strong delivery system is needed.

- Policy makers must invest more in contextualised policies and programmes that acknowledge the diversity of women entrepreneurs. It is clear that "one size does not fit all."

- Entrepreneurship education can be used more effectively to support women entrepreneurs. Gender-neutral and women-focused education must be offered early to instil confidence, skills and abilities in young girls to identify entrepreneurial opportunities. Such education is important across all post-secondary disciplines, but particularly in disciplines dominated by women, such as the Humanities.

- A growing and diverse array of funding sources are being made available to women entrepreneurs. However, many of these gender-neutral initiatives do not adequately account for gender differences in founder motivations, circumstances or contexts.

- More needs to be done to ensure that entrepreneurship ecosystems reflect the needs of diverse women entrepreneurs. This includes increasing funding for organisations and initiatives that foster inclusive entrepreneurship cultures, address gender barriers within mainstream interventions and offer women entrepreneurs direct support.

- Strong regulatory institutions are needed to promote and support women's entrepreneurship, particularly in areas such as parental leave and care responsibilities, where employees of large employers often have more access to supports than employees of small businesses. 


\section{The gender gap in entrepreneurship has reduced over the past 20 years}

Women have traditionally been less active in entrepreneurship than men. Between 2015 and 2019, fewer than $6 \%$ of women in OECD countries were actively involved in creating a business relative to more than $8 \%$ of men. While gender gaps vary across countries, they are nevertheless present in all OECD countries. The gap is explained by a range of factors, including differences in individual motivations and intentions for entrepreneurship, levels of entrepreneurship skills, access to finance, networks and social attitudes towards women and men entrepreneurs. Many of these barriers are inter-dependent. For example, low levels of entrepreneurship skills and financial knowledge hinder an entrepreneur from exploring all possible options for accessing financing.

Moreover, women entrepreneurs tend to operate different types of businesses than men. On average, women entrepreneurs are more likely to operate businesses in service sectors and on a parttime basis, are less likely to have employees and to export, have growth intentions and to introduce new products and services (OECD/EU, 2019). Many of these characteristics are inter-related.

Gender gaps in self-employment reduced between 2000 and 2019 in 25 of 31 OECD countries, where data are available. The gender gap in rate of self-employment reduced by as much as 5 percentage points in five countries (Iceland, Ireland, New Zealand, Hungary and Greece), and reduced by smaller amounts in 20 countries. However, the gaps between women and men increased in six countries (Estonia, Slovak Republic, Portugal, Poland, the Netherlands and Austria). Furthermore, the gap between the proportion of self-employed women and men with employees grew between 2000 and 2019 in approximately two-thirds of the OECD countries.

\section{COVID-19 risks reversing gains in women's entrepreneurship}

The COVID-19 pandemic may exacerbate gender gaps in entrepreneurship. Women entrepreneurs have been disproportionately impacted by the COVID-19 pandemic. Women entrepreneurs are more likely to operate businesses in hard-hit sectors (e.g. personal services, tourism, retail, arts and entertainment), be less financially resilient and have less finance knowledge and confidence. Moreover, women bear a disproportionate share of caregiving responsibilities in households, which restricts the time available for their businesses, and renders them less equipped to pivot business activities in response to the crisis (e.g. less access to external advice, less likely to be online). This has resulted in higher closure rates among businesses operated by women relative to those operated by men.

The large-scale COVID-19 liquidity support measures that governments have introduced have been implemented quickly but may not be gender-sensitive. Governments had to act quickly to support small businesses and the self-employed with liquidity support tools (e.g. loans and wage subsidies). However, these have generally been simple undifferentiated tools that follow a "one size fits all approach." Such support may not filter equally to all small businesses. Women-owned enterprises might not benefit as much as men-owned businesses because, on average, they are less likely to use bank loans (many programmes rely on existing bank products) or are smaller (some supports have revenue or employment thresholds). Differences in financial knowledge also play a role.

\section{Traditional gender roles exert negative influences on women's entrepreneurship}

Gender roles in society can have negative influences on the scale and nature of women's entrepreneurship. In many OECD countries, tax and family policies continue to reinforce traditional gender roles. Income tax models that favour single income earners in households can dissuade women from participating in entrepreneurship. In addition, while family policy is evolving to provide greater support 
for women's participation in the labour market, a bias towards employment over entrepreneurship remains. This can be illustrated by parental leave and childcare policies, which can negatively influence the feasibility of entrepreneurship for many women.

Greater efforts are needed to legitimise, celebrate and normalise women's entrepreneurship. The policy insight notes in this report confirm that women entrepreneurs often retain lower status then men entrepreneurs, even within OECD countries with high perceived levels of gender equality. This is demonstrated by women's entrepreneurship supports that are underpinned by volunteerism, making supports vulnerable to fatigue and high levels of turnover among time-stretched unpaid workers. Governments need to do more to promote women's entrepreneurship, such as promoting diverse role models, recognizing leaders through award programmes and funding women-focused support services.

\section{Women's entrepreneurship policies are well-established in many countries}

Women's entrepreneurship policies have been in place in some countries for decades. This report shows that, to varying degrees, women's entrepreneurship policies and programmes are in place in all of the 27 countries and regions covered. The rationale behind targeted policies and programmes to promote and support women's entrepreneurship is typically built on three arguments:

- Women are under-represented in entrepreneurship compared with men. Closing the gender gap yields welfare gains for individual women and society as a whole.

- There is evidence that women are held back in entrepreneurship by institutional and market barriers, such as social attitudes that discourage them from creating businesses, and market failures that make it more difficult to access resources like skills training, finance and networks.

- Evaluations suggest that women are less aware of public enterprise support programmes, and that mechanisms used to select programme participants can favour men (OECD/EC, 2017).

\section{Women's entrepreneurship policy frameworks are needed to underpin individual policy actions}

Women's entrepreneurship policy is a "work in progress" rather than a finished product. In some instances, the policy insight notes provide evidence of policy and practice working together to achieve the desired goals. In other instances, the notes show a lack of effective policy or presence of policies and practices that are not consistent. The good news is that all countries highlighted are engaged in women's entrepreneurship practice, with an impressive array of programmes and initiatives. A caveat, however, is that projects and funding are often vulnerable to economic and political changes without underpinning policy frameworks. This threat lends support to the importance of women's entrepreneurship policy as a means for informing, grounding and sustaining different types of women's entrepreneurship programmes and practices. Conversely, practices that are not linked to policy may represent areas of opportunity and serve as a signpost for under-valued areas of policy.

\section{Women's entrepreneurship interventions must be contextualised}

Context in the form of institutions, culture and social norms has important effects on the existence or non-existence of women's entrepreneurship policies, as well as on the priorities stressed in such policies. As an example, policies in some developed economies, such as the United States, the United Kingdom and Australia, tend to focus on expanding the entrepreneurial ecosystem in ways that will benefit women entrepreneurs. In contrast, developing or in-transition economies tend to focus on 
foundational challenges to gender equity, social justice, economic security and empowerment. Similarly, women-focused programmes reflect the institutional, cultural and normative characteristics of the respective countries. Such influences are reflected in what gets done to support women entrepreneurs, and who does the work. In some instances, for example, the role of government is to create the legal and regulatory framework that supports women's entrepreneurship, while providing resources. In other country contexts, government plays a more directive role in creating infrastructure, funding and establishing small business support networks. Both approaches can work, but are different and reflect corresponding differences in the country-level entrepreneurial contexts.

\section{More effective implementation of policies is needed to achieve policy objectives}

Policy makers should develop a means for "closing the loop" to ensure that desired outcomes for women's entrepreneurship policies are clearly articulated and measured on an ongoing basis. Few countries have established systematic methods for monitoring the impacts of women's entrepreneurship policy against policy objectives, and for identifying progress relative to targets and the effectiveness of different measures. As an example, a common intervention to support women entrepreneurs is womenfocused entrepreneurship training and skills development programmes. To date, there is limited objective evidence within or across countries demonstrating the impacts of such programmes in increasing women entrepreneurs' access to resources and enhancing the viability of their firms. This reflects a lost opportunity to learn from high impact policy interventions and to demonstrate benefits. Lack of evidence may lead to the vulnerability of programme funding. Since many of the practices described in the report are partially funded by taxpayers, it is imperative to demonstrate the impacts against pre-determined objectives.

\section{Greater efforts are needed to address gender gaps in entrepreneurship skills}

There are benefits to offering dedicated entrepreneurship training for women. Benefits include increasing the involvement of women in business creation, augmenting the quality of start-ups founded by women, and enhancing the relevance and attractiveness of support for women entrepreneurs. While many countries are implementing dedicated entrepreneurship training programmes for women, approaches are often poorly designed and not well-connected to other small business supports. Moreover, there are many examples of duplication among offers, which can create confusion among the targeted entrepreneurs. Governments need to improve dedicated training, coaching and mentoring schemes by contextualising the offers (e.g. for local conditions, different profiles of women entrepreneurs, different sectors of start-up projects) and bundling supports into cohesive systems that provide a range of inter-connected and reinforcing schemes.

However, the development of dedicated training programmes is not sufficient to close the gender gap in entrepreneurship skills. Gender-neutral entrepreneurship education needs to be further developed and implemented early in the mainstream education system so that young girls understand that entrepreneurship is a viable career option. Such programming can instil confidence, skills and abilities to identify and exploit entrepreneurial opportunities. Entrepreneurship education is important across all academic disciplines, but particularly in disciplines dominated by women, such as the Humanities.

\section{Greater use of dedicated measures is needed to address gender gaps in access to financing}

There is a commitment by most governments to increase women entrepreneurs' access to financing. While a range of mechanisms are in place, a broader use of instruments, such as loan 
guarantee schemes and microfinance, is needed. This includes increased access to capital for growthoriented small businesses. Regardless of the type of instrument used, the policy insight notes in this report show that mainstream financing sources and government's use of small business finance schemes are not always as effective for women as they are for men. A greater use of women-focused small business financing programmes is needed.

\section{References}

Coleman, S., C. Henry, B. Orser, L. Foss and F. Welter (2019), "Policy Support for Women Entrepreneurs' Access to Financial Capital: Evidence from Canada, Germany, Ireland, Norway, and the United States", Journal of Small Business Management, Vol. 57, No. 2, pp. 296-322.

Henry, C., B. Orser, S. Coleman and L. Foss (2017), "Women's entrepreneurship policy: a 13 nation cross-country comparison", International Journal of Gender and Entrepreneurship, Vol. 9, No. 3, pp. 206-228.

OECD/EU (2019), The Missing Entrepreneurs 2019: Policies for Inclusive Entrepreneurship, OECD Publishing, Paris, https://doi.org/10.1787/3ed84801-en. 


\section{The state of women's entrepreneurship}

This chapter presents gender-disaggregated indicators on entrepreneurship and self-employment for OECD countries and beyond. These include recent data on entrepreneurship activity rates and the characteristics of these activities, as well as data on barriers to business creation by gender. The section considers how the COVID-19 pandemic may impact gender gaps in entrepreneurship. 


\section{The gender gap has been closing among solo entrepreneurs...}

Promoting women's entrepreneurship is increasingly viewed as contributing to economic growth, job creation, income equality and social inclusion (OECD/EU, 2019; OECD, 2017). One estimate has suggested that if the gender gap in entrepreneurship was closed, global GDP could rise by as much as $2 \%$, or USD 1.5 trillion (Blomquist et al., 2014). While it is important for individuals to have a range of choices in the labour market, and recognising that many will not choose entrepreneurship, women tend to have latent entrepreneurial potential that is not yet realised in most countries. Policy makers can help to unlock such potential, while recognising that women are heterogeneous with differences in motivations, intentions, experiences, opportunities and projects.

One of the most commonly used measures of entrepreneurship is self-employment, as shown in Figure 2.1. The numbers are dominated by the solo self-employed, i.e. self-employed individuals without employees. In 2019, the self-employment rate for women ranged from less than $5 \%$ in Japan, Norway and Denmark to nearly $25 \%$ in Greece, Chile and Mexico. Even given such differences, the proportion of women who were self-employed was lower than the proportion of men in all countries. Men were more than twice as likely as women to be self-employed in Denmark, Estonia, Ireland, Japan, Sweden and Turkey.

\section{Figure 2.1. The gender gap in self-employment is closing in most countries}

Share of self-employment among employment, 2019 or latest available year

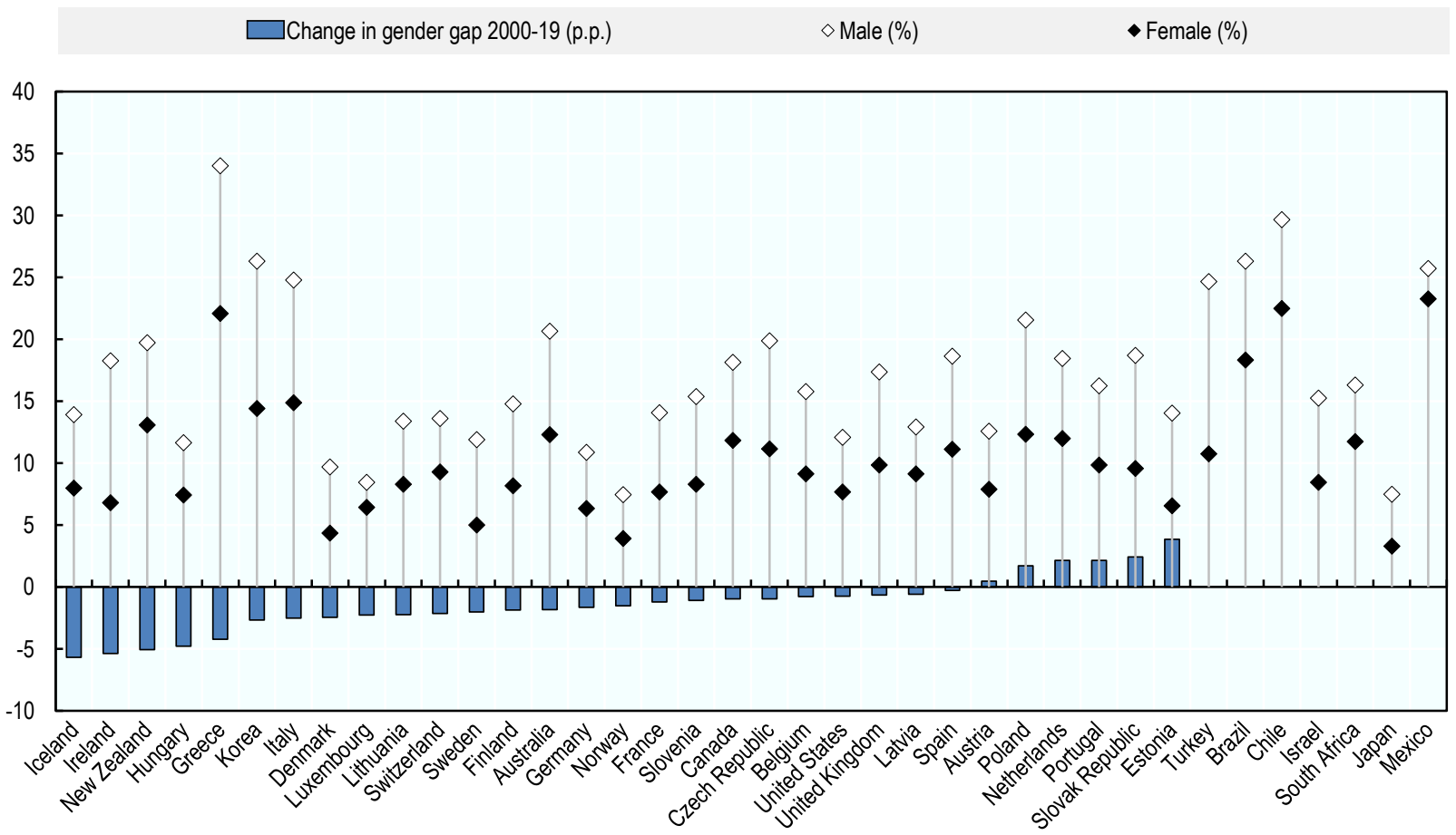

Note: Data for Austria, Belgium, Czech Republic, Denmark, Estonia, Finland, France, Germany, Greece, Hungary, Iceland, Ireland, Italy, Latvia, Luxembourg, Netherlands, Norway, Portugal, Slovak Republic, Slovenia, Spain, Sweden, Switzerland, Turkey and the United Kingdom refer to 2018. Data for Australia, Chile, Korea, Japan, Mexico and South Africa refer to 2017. Data for Israel refer to 2016. Data for Brazil refer to 2015. Source: OECD (2020), Self-employed without employees (indicator), doi: 10.1787/5d5d0d63-en (accessed on 01 December 2020); OECD (2020), Self-employed with employees (indicator), doi: 10.1787/b7bf59b6-en (accessed on 01 December 2020). 
Among the 31 OECD countries where data are available, the gender gap in self-employment reduced in 25 countries between 2000 and 2019 (Figure 2.1). Many factors could explain this reduction - policy interventions to support women entrepreneurs, the economic cycle and the ageing of the population of entrepreneurs (gender gaps tend to be slightly smaller among younger cohorts). However, one of the most important factors has been a decline in the share of men who are self-employed over the past decade (OECD/EU, 2019).

\section{...but the gender gap was growing among self-employed with employees}

Self-employed women tend to operate smaller businesses with fewer employees. Overall, women were approximately two and a half times less likely than men to be self-employed and have employees in OECD countries in 2019. There was essentially no gender gap in Ireland in 2019, but this was an exception. Selfemployed men were more likely than self-employed women to have employees in every other OECD country, and were more than twice as likely to be employers in Israel, Mexico, South Africa and Turkey (Figure 2.2).

Furthermore, the gender gap among the self-employed with employees increased between 2000 and 2019. This is concerning because compared with the solo self-employed, this group of entrepreneurs has stronger economic and social impacts. The increase in the gap between the proportion of self-employed women and men with employees grew in about two-thirds of OECD countries (Figure 2.2). The gap increased the most in the Slovak Republic and Switzerland. By contrast, the gap narrowed in some countries, notably Portugal and Korea.

This difference in the size of women-owned businesses is related to the fact that self-employed women, on average, operate different types of businesses than self-employed men. In most OECD countries, $70 \%$ or more of self-employed women work in the services sector, compared to about $50 \%$ of men (OECD/EU, 2019). Some of the traditional sectors in which many women's businesses operate are characterised by low barriers to entry, high competition, low productivity and low profit margins - where enterprises tend to stay small and be low value-added enterprises. Self-employed women also tend to work fewer hours than self-employed men, but work more hours than women who work as salaried employees (OECD/EU, 2019). 
Figure 2.2. Women entrepreneurs are less likely to be employers and the gender gap is growing

Share of self-employed with at least one employee, 2019 or latest available year

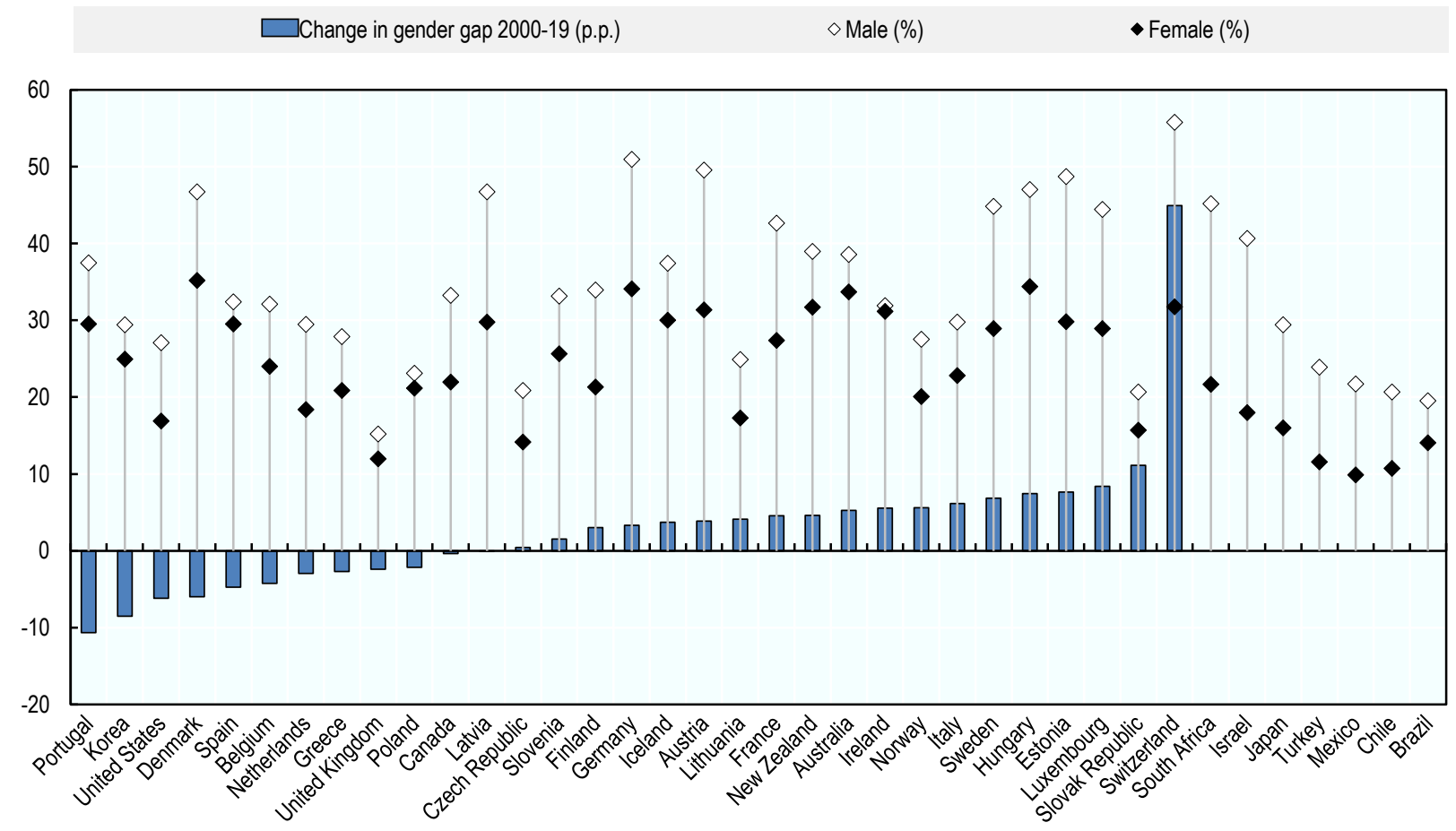

Note: Data for Austria, Belgium, Czech Republic, Denmark, Estonia, Finland, France, Germany, Greece, Hungary, Iceland, Ireland, Italy, Latvia, Luxembourg, Netherlands, Norway, Portugal, Slovak Republic, Slovenia, Spain, Sweden, Switzerland, Turkey and the United Kingdom refer to 2018. Data for Australia, Chile, Korea, Japan, Mexico and South Africa refer to 2017. Data for Israel refer to 2016. Data for Brazil refer to 2015. Source: OECD (2020), Self-employed without employees (indicator), doi: 10.1787/5d5d0d63-en (accessed on 01 December 2020); OECD (2020), Self-employed with employees (indicator), doi: 10.1787/b7bf59b6-en (accessed on 01 December 2020).

\section{COVID-19 is exacerbating gender gaps in entrepreneurship}

The COVID-19 pandemic is having a profound shock on economies and labour markets around the world (OECD, 2020) and the impacts have been devastating for many entrepreneurs. Women entrepreneurs are being hit much harder than men.

Business closure rates increased during the COVID-19 pandemic and women-led businesses have closed to a greater extent than their men-led counterparts (Figure 2.3). Globally, the closure rate for women-led businesses (27\%) was 7 percentage points higher than for men-led SMBs $(20 \%)$ during May 2020 . While the gender gap has closed over time, the closure rate for women-led businesses remained 2 percentage points higher than for men-led businesses. In October 2020, $16 \%$ of women-led SMBs were closed, in aggregate, relative to $14 \%$ of men-led businesses. However, with rising infection rates and the possibility of new lockdowns, there is a risk that these declines could be reversed. The gender gap in closure rates narrowed across all regions between May and October, except for sampled countries in the Middle East and North Africa region where the gender gap increased slightly.

One of the key reasons for this is that women are over-represented - both as self-employed and employees - among the hardest hit sectors (Figure 2.4). Overall, women account for one-third of the self-employed across most OECD countries and nearly half of employees, but they have greater shares among sectors that have been affected the most by containment and confinement measures - personal services, accommodation and food services, arts and entertainment, and retail trade. 
Figure 2.3. Female-operated businesses have been more likely to close during the COVID-19 pandemic

Business closure rates in May and August 2020

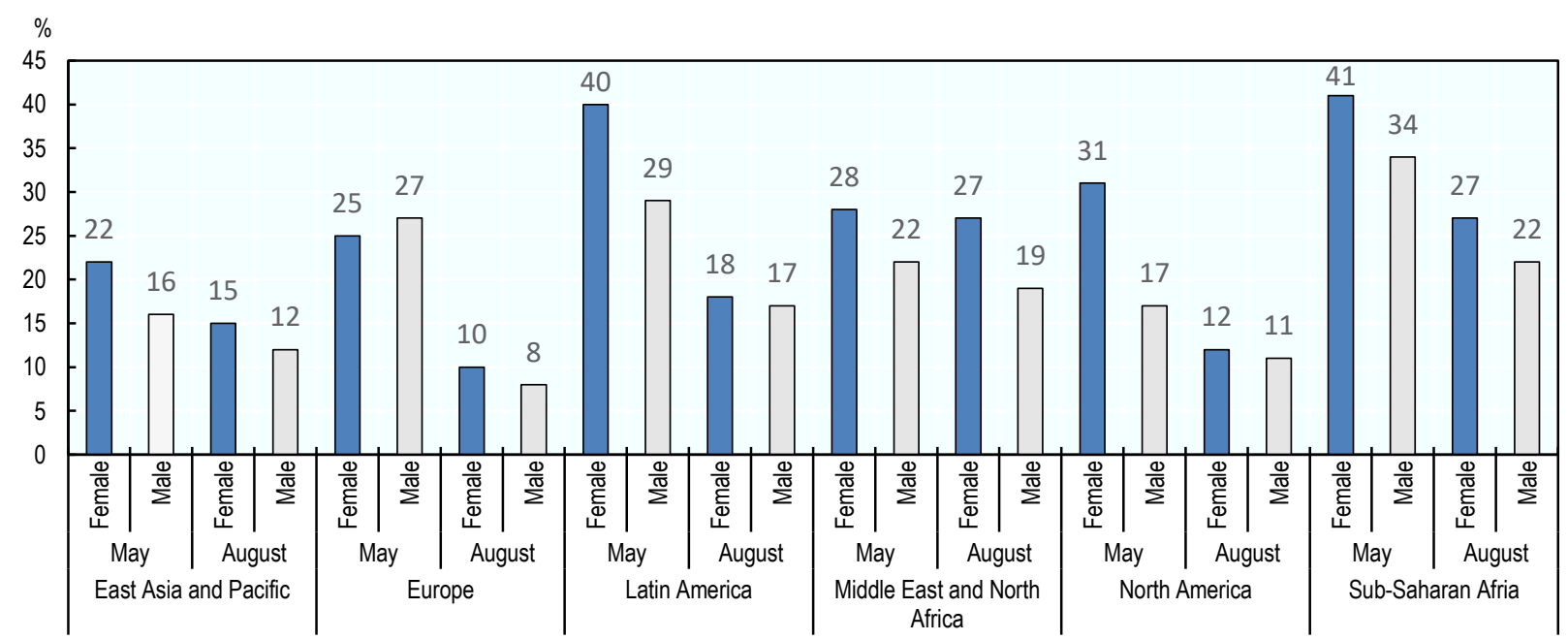

Source: Facebook/OECD/World Bank (2020), "The Future of Business Survey", https://dataforgood.fb.com/wp-content/uploads/2020/10/Stateof-Small-Business-Report-Wave-IV.pdf.

Figure 2.4. Women are over-represented in the sectors hardest hit by COVID-19

Share of self-employed and employees in France, Germany, Italy, Netherlands, Poland, Spain and United Kingdom, 2019

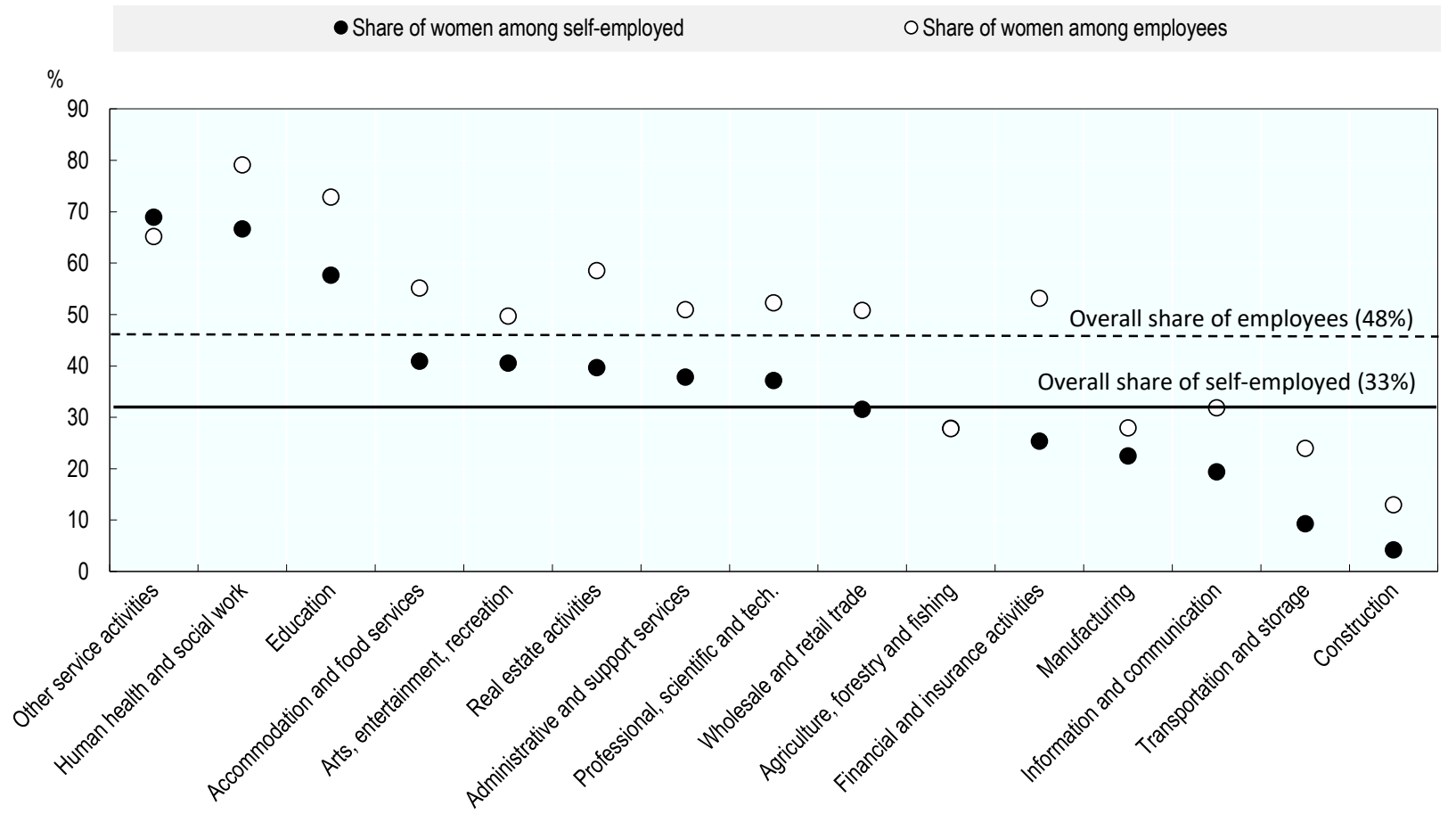

Source: Eurostat (2020), Labour Force Survey, https://ec.europa.eu/eurostat/web//fs/data/database. 
Another reason for higher closure rates among women-led businesses is that COVID-19 has also exacerbated the gender divide at home since the burden of additional domestic responsibilities has disproportionately fallen upon women business leaders. About one-quarter of all women business leaders stated that they spent six hours or more per day on domestic responsibilities between May and October 2020 , whereas only $11 \%$ of all male business leaders reported undertaking this amount of household work (Facebook/OECD/World Bank, 2020). More specifically, 25\% of women business leaders reported that home-schooling impacted their ability to focus on work compared to $19 \%$ of men business leaders (Figure 2.5). Similarly, women business leaders were more likely than their men counterparts to take on household chores and childcare responsibilities. This increased work at home has decreased the time available for women entrepreneurs to dedicate to their business.

\section{Figure 2.5. Female business leaders have been more likely to assume household responsibilities during the COVID-19 pandemic}

Proportion of business leaders, May to October 2020

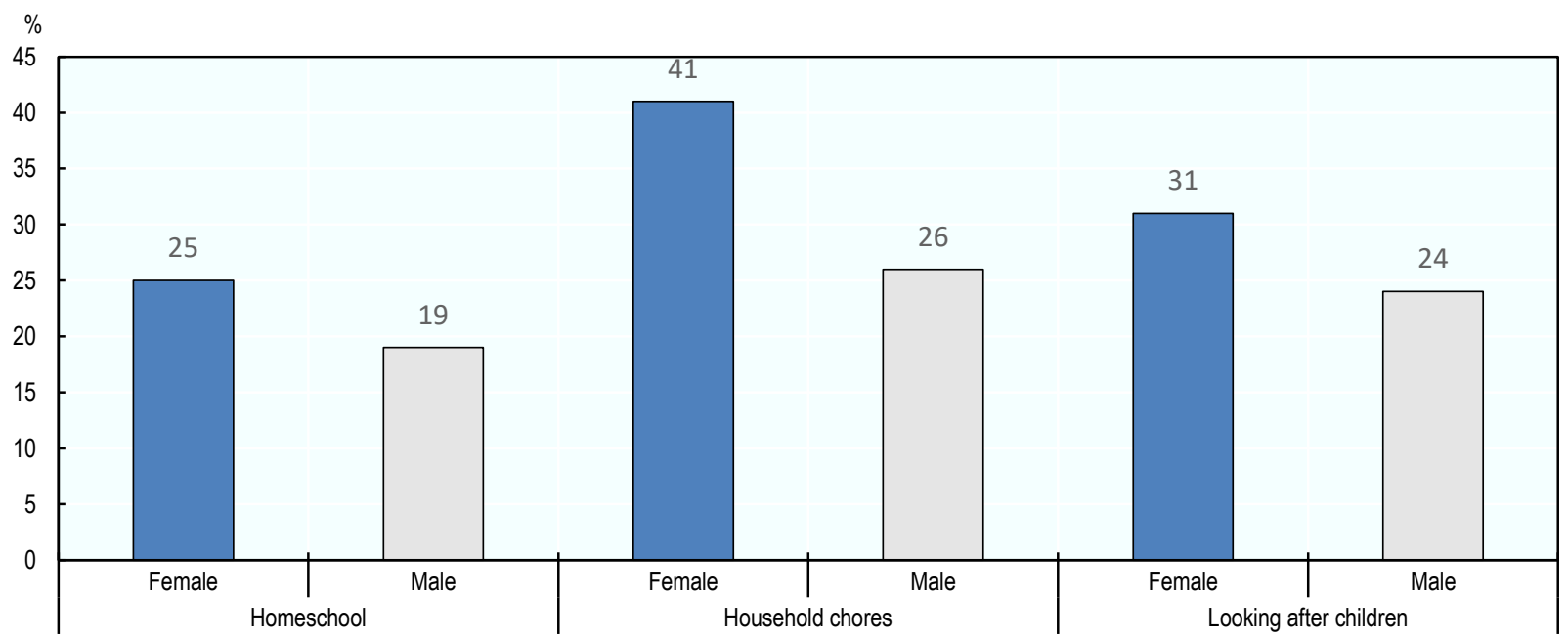

Source: Facebook/OECD/World Bank (2020), "The Future of Business Survey”, https://dataforgood.fb.com/wp-content/uploads/2020/10/Stateof-Small-Business-Report-Wave-IV.pdf.

The disproportionate impact of the COVID-19 pandemic on women entrepreneurs exacerbating gender gaps in entrepreneurship. Even before the COVID-19 pandemic, women were less active in early-stage entrepreneurship overall, i.e. creating start-ups or managing new businesses that are less than 42 months old. In 2019, women in OECD countries were two-thirds as likely as men to be involved in early-stage entrepreneurship. The gender gap was greatest in Japan and smallest in Spain, where women were about $95 \%$ as likely as men to be involved in early-stage entrepreneurship (Figure 2.6). These gaps can be explained by several factors, including differences in motivations for entrepreneurship, differences in how social attitudes affect education pathways and labour market activities, gaps in entrepreneurship skills, smaller entrepreneurship networks and greater difficulties accessing start-up financing. Many of these barriers will be discussed in greater detail later in this chapter. 


\section{Figure 2.6. There is a larger gender gap in early-stage entrepreneurship}

Share of the population involved in early-stage entrepreneurship, 2019

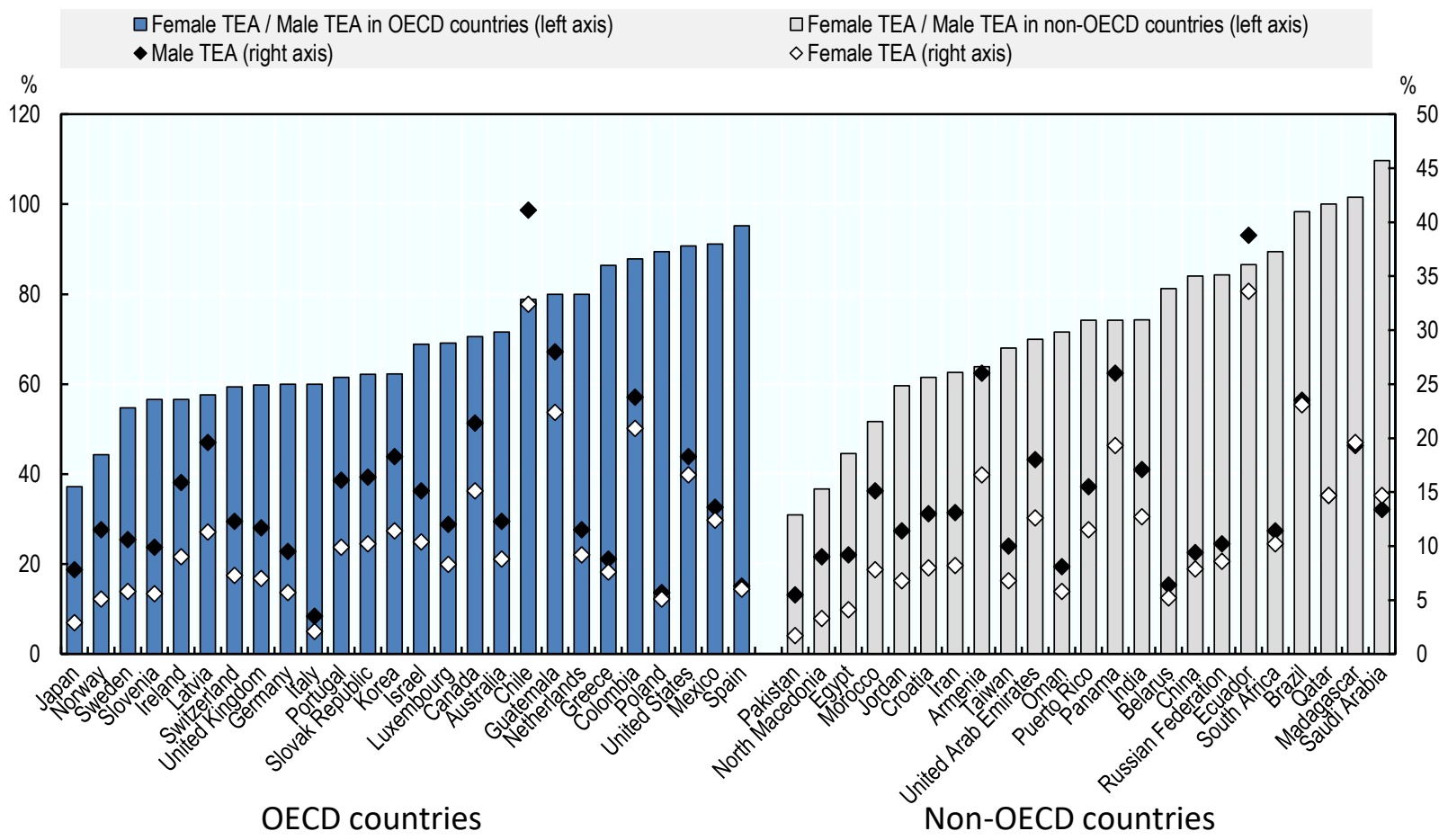

Note: Early-stage entrepreneurship measures the share of the population that self-reports working towards launching a new business start-up or managing a business that is less than 42 months old.

Source: Global Entrepreneurship Monitor (GEM) (2020), "Global Entrepreneurship Monitor 2019/2020 Global Report", https://www.gemconsortium.org/report/gem-2019-2020-global-report.

Governments introduced large-scale liquidity support measures (e.g. loans and wage subsidies and tax deferrals) at the outset of the COVID-19 confinement measures to help businesses survive the crisis. The rapid response was essential. However, little attention was paid to ensuring that these measures were gender-sensitive. As a result, many women-owned enterprises were not supported by "one size fits all" measures, in part because they are less likely to use bank loans (many programmes rely on existing bank products) or are smaller on average (some supports have size thresholds) than men-owned enterprises. Differences in financial knowledge may also play a role.

\section{Women often have different motivations and intentions in entrepreneurship than men}

Women often become entrepreneurs for different reasons than men and have different growth expectations and intentions (OECD/EU, 2019; OECD/EU, 2018). There is a body of research that suggests that many women go into self-employment to benefit from the flexibility it provides in order to manage work-family responsibilities, while others start a business to avoid the "glass ceiling" in employment. This point is supported by many studies based on small samples and self-reported answers (OECD/EC, 2017). There are also studies that find that women's self-employment decisions are influenced by business considerations (e.g. state of the economy, access to finance) and social factors (e.g. care responsibilities) in much the same way that men's decisions are (Saridakis et al., 2014). 
With respect to expectations, for example, new women entrepreneurs are less likely them men to report that they expect to create at least 19 jobs over the next five years. This suggests that women entrepreneurs are, on average, less oriented towards seeking high employment growth compared to men. Over the period 2015 to 2019, new women entrepreneurs were $60 \%$ as likely as new men entrepreneurs to anticipate creating at least 19 jobs over the next five years in OECD countries. There were seven OECD countries where more than $10 \%$ of new women entrepreneurs expected this level of growth, whereas this proportion of men was reported in 24 countries (Figure 2.7).

The survival rates of women-owned businesses are comparable to men-owned businesses in many countries. There is evidence that women-owned businesses earn less revenue and demonstrate lower labour productivity (OECD/EU, 2019; OECD, 2012). These differences can be explained, in part, by gender differences in sector engagement, motivations and business strategies. As noted earlier in the chapter, women-owned businesses are over-represented in service sectors and under-represented in sectors with high value-added potential, such as, science, technology and engineering sectors (Marlow and McAdam, 2013).

\section{Figure 2.7. High-growth expectations}

Share of early-stage entrepreneurs that expect to create at least 19 jobs over the next five years, 2015-19

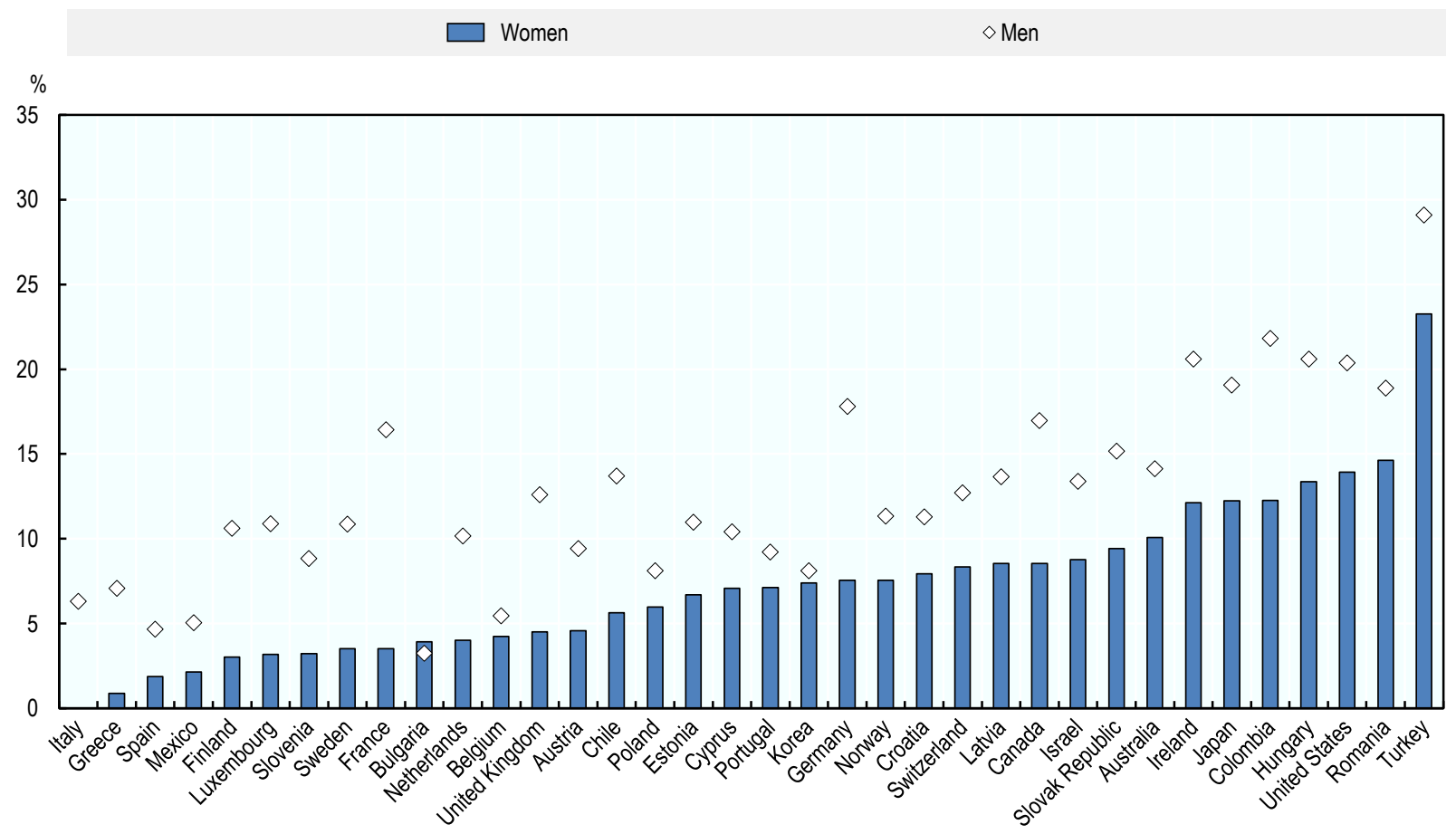

Note: Early-stage entrepreneurs are those involved in creating a new business or managing a new business that is less than 42 months old. Source: OECD (2020), special tabulations of the Global Entrepreneurship Monitor's adult population survey.

\section{Women entrepreneurs face a range of subtle barriers to start-up}

All entrepreneurs face a variety of challenges in starting and sustaining their businesses. While many of these barriers are common to men and women, some obstacles are more likely to be faced by women or are more significant for women entrepreneurs (OECD/EU, 2019). 


\section{Unsupportive culture}

While women's social and economic participation has advanced substantially over the past few decades, negative gender stereotypes persist. Women face a range of subtle barriers associated with occupational gender roles that can exert negative influences on their labour market decisions, including in entrepreneurship and self-employment.

Entrepreneurship has a long history as a "masculine" phenomenon, which has been sustained by cultural, social and economic processes. Gender biases are reinforced by formal education systems. These have resulted in embedded attitudes and norms that give women's entrepreneurship a lower level of social and cultural legitimacy (Ogbor, 2000). These affect the market position and image of women-owned firms, constrain the mobilisation of resources (Brush et al., 2004) and impede the realisation of entrepreneurial potential (Marlow and Patton, 2005).

Social and cultural attitudes reinforce traditional gender roles, which lead some women to self-restrict their business and entrepreneurship activities to "feminised" professions, sectors and business fields. Furthermore, norms about how genders "should behave" lead some women to self-restrict activities, including securing important resources such as human, financial and social capital.

The relatively small number of women entrepreneurs who are perceived to be "successful" and personified as role models is detrimental in encouraging others to consider entrepreneurship as a career option, especially in science, engineering and technology related fields. The masculine ideal of a successful entrepreneur is perpetuated by social media, education and through policies in most countries.

One way in which social attitudes are visible is through attitudes towards failure. Women in OECD countries are nearly $20 \%$ more likely than men to report that "fear of failure" is a barrier to business creation (OECD/EU, 2019). The proportion of women self-reporting this barrier ranges from about $30 \%$ in Norway and Korea to $66 \%$ in Greece (Figure 2.8). 
Figure 2.8. Fear of failure as a barrier to business start-up

Share of the population that reports that a "fear of failure" is a barrier to business creation, 2015-19

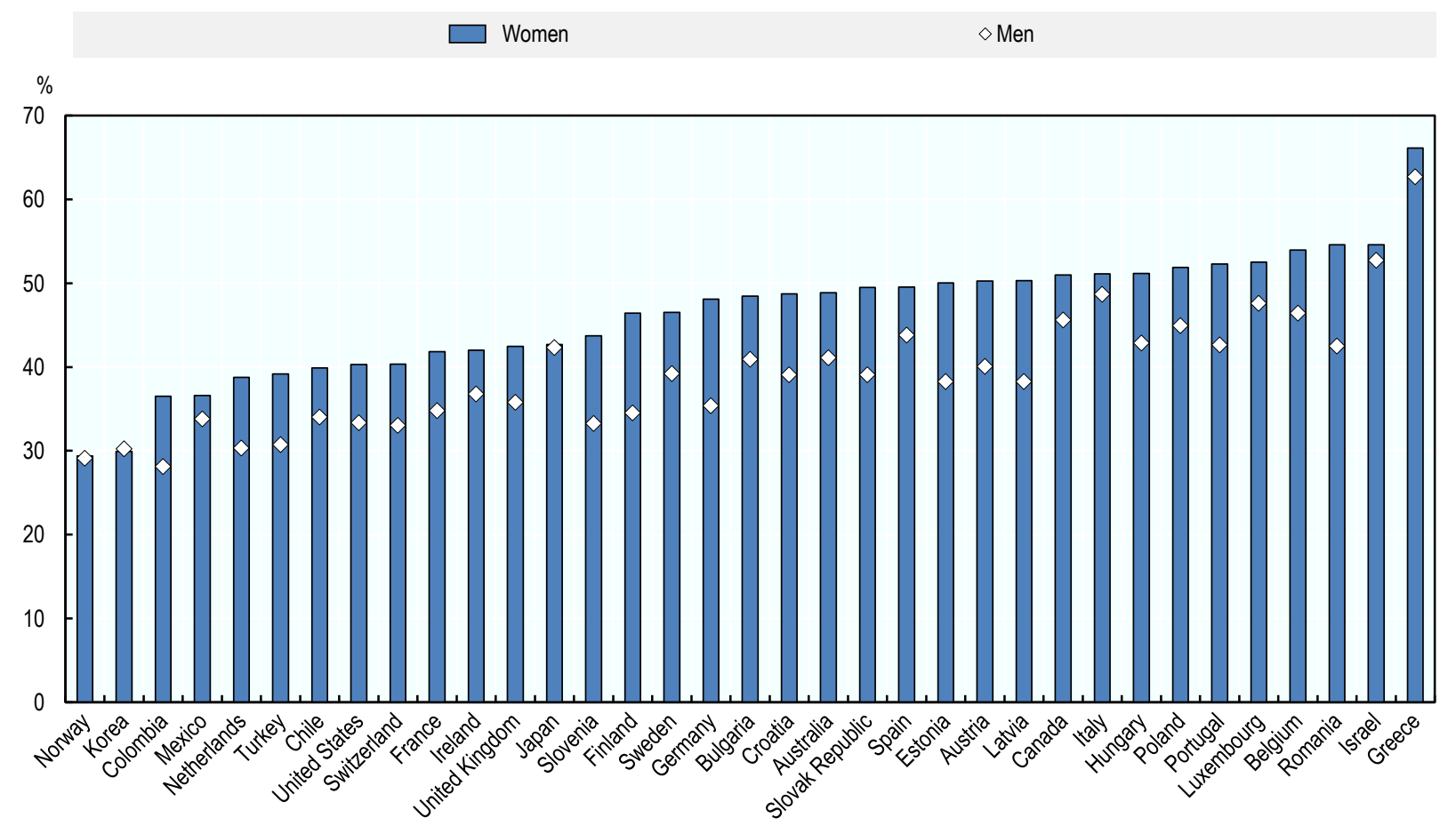

Source: OECD (2020), special tabulations of the Global Entrepreneurship Monitor's adult population survey.

\section{Lack of entrepreneurial skills}

One of the greatest challenges cited by entrepreneurs is a lack of entrepreneurial skills. Women entrepreneurs typically have less experience in running businesses and therefore less management experience at start-up and smaller business networks (Shaw et al., 2009).

Across OECD countries, women were about three-quarters as likely as men to report having the skills and knowledge needed to start a business between 2015 and 2019 (Figure 2.9). The share of women selfreporting that they have entrepreneurship skills over this period ranged from about $6 \%$ in Japan to more than half in the United States $(51 \%)$, Croatia (51\%), Chile $(60 \%)$ and Colombia $(62 \%)$. Moreover, there also appears to be a gender gap in perceived access to entrepreneurship training (OECD, 2016). 
Figure 2.9. Entrepreneurial skills

Share of the population that reports having the skills and knowledge to successfully start a business, 2015-19

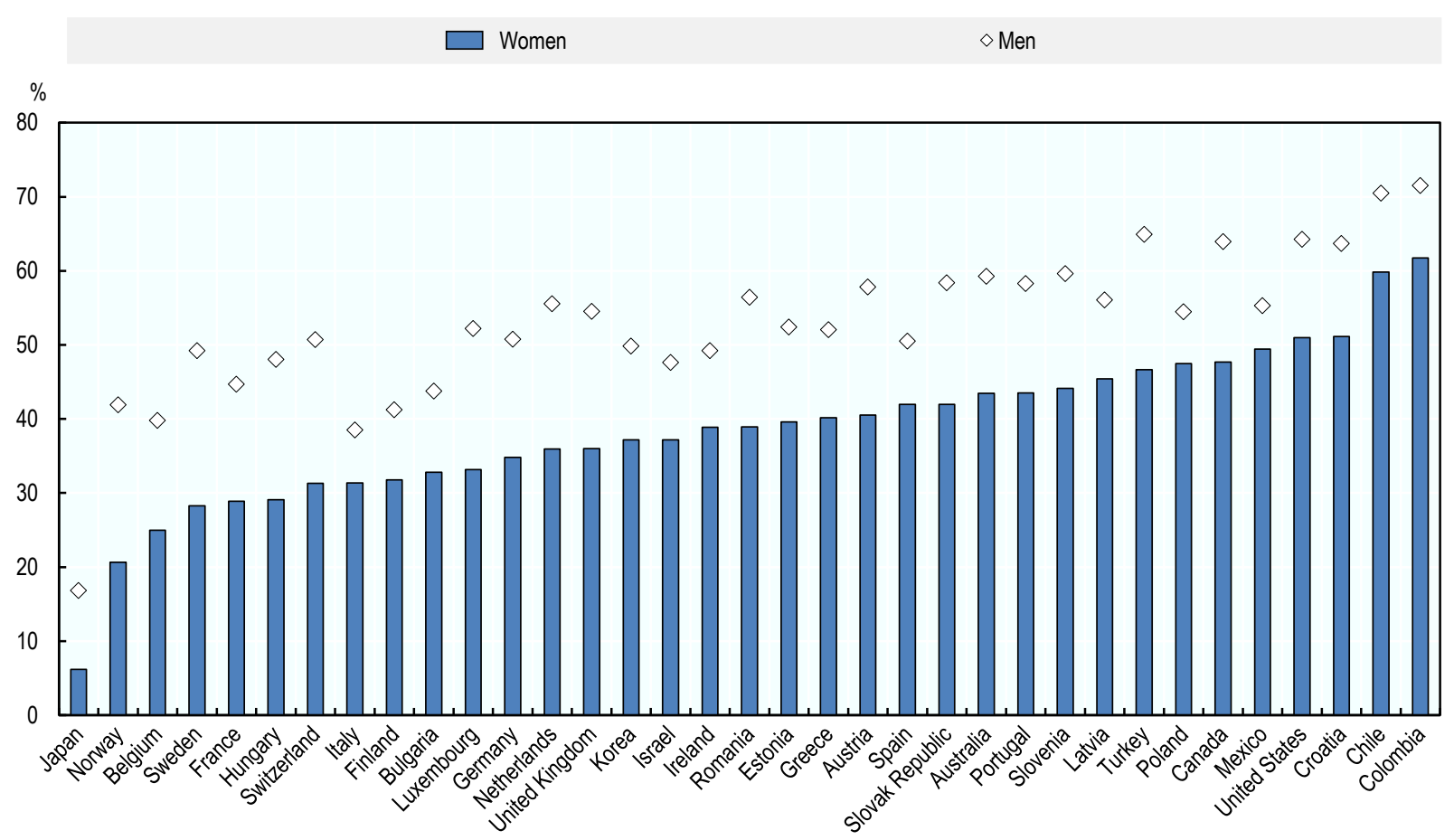

Source: OECD (2020), special tabulations of the Global Entrepreneurship Monitor's adult population survey.

\section{Women entrepreneurs struggle to access finance}

Access to finance is another commonly reported barrier to business creation. Women entrepreneurs generally have lower levels of capitalisation and are more reliant on owner equity and insider financing than men (OECD/EU, 2019; Coleman and Robb, 2016). They also grapple with greater challenges in accessing debt financing due to the sectors in which they operate, and unconscious investor bias (Carter et al., 2007). While evidence is inconclusive, in some countries these barriers result in gender-based differences in credit terms, such as higher collateral requirements and interest rates, despite controlling for structural characteristics like sector and size of business.

\section{Women tend to have smaller and less effective entrepreneurial networks}

There is long-standing evidence that women tend to retain smaller and less diverse entrepreneurship networks than men, which hinders access to ideas and resources. Entrepreneurship networks are groups of interconnected entrepreneurs, business service providers and other actors who can provide information in reciprocal relationships. Networks help entrepreneurs access financing, find business partners, suppliers, employees and customers, and generate ideas for new products, processes, organisational methods and business models. They can also influence an individual's perception of the desirability and feasibility of entrepreneurship.

Research suggests that the networks of women entrepreneurs have (on average) a different composition than those of men (OECD/EU, 2015). Women are more likely to populate their entrepreneurship networks with friends, family and educators, whereas the networks of men are more reliant on business service providers and other entrepreneurs (OECD/EU, 2015). Therefore, women entrepreneurs are less likely to interact with individuals who control critical resources (Brush et al., 2004). In contrast, the entrepreneurship 
networks of men typically have more contacts with greater social and economic power, which can be advantageous in assisting in the gathering of information, resources and referrals (Uzzi, 1999).

\section{Family and tax policies can discourage women's labour market participation, including entrepreneurship}

Regulatory institutions, such as social welfare systems, tax policies and family policies, impact the costs and feasibility of entrepreneurship for women. Tax policies that favour a dual-earner model are likely to foster women's labour market participation and business activity. Women's entrepreneurship is also affected by the extent to which they are able to reconcile family and professional obligations. This barrier is particularly challenging in those countries where traditional gender roles go hand in hand with a lack of public or private childcare and eldercare services. Furthermore, maternity and paternity leave provisions have a confirmed impact on the general rate of women's entrepreneurship.

\section{Policy can play an important role in supporting women's entrepreneurship}

Policy should address market, institutional and policy implementation failures that women face in entrepreneurship. In this respect, the central role of policy includes increasing the availability of resources to women entrepreneurs, including skills, finance and networks. Common approaches include offering entrepreneurship training, coaching and mentoring, developing women-focused entrepreneurship networks and facilitating access to a range of appropriate entrepreneurial finance opportunities.

A core policy question for many governments is whether support to women entrepreneurs should be delivered in dedicated programmes by specialist agencies, or whether women's entrepreneurship support can be adequately integrated into mainstream programmes with accompanying gender-sensitivity training, gender targets and quotas, and programme re-designs. Both the dedicated and mainstream approaches are used in OECD countries. The approach selected is often determined by the size of the gender gap in entrepreneurship and social attitudes towards women in society and the labour market. Countries where women face fewer challenges in accessing education and opportunities in the labour market (e.g. Finland, Germany, Austria) tend to deliver women's entrepreneurship support largely through mainstream programmes. However, addressing the specific needs of women's entrepreneurship through access to general entrepreneurship support by women may be more challenging in other countries, where there may be a preference for dedicated women's entrepreneurship support.

Regardless of the approach taken, the key to success is to ensure that entrepreneurship support is both accessible and relevant to women. If dedicated women's entrepreneurship programmes are developed, it is important to build linkages with the broader business community and mainstream support institutions. This is to ensure that women-specific support does not reinforce barriers that women entrepreneurs face. Furthermore, it is important to better inform mainstream business support providers and investors about the needs and challenges of women entrepreneurs. This is to ensure that support is delivered effectively and that biases are removed in programming and investments.

It is also important for policy makers to go beyond measures that aim to address the challenges that individual women entrepreneurs face and to examine the broader institutional context affecting women's entrepreneurship. More attention is needed to influence the environment and remove barriers to women's entrepreneurship at source. For example, the role of education is key in encouraging women to go into STEM fields where there tends to be strong opportunities for high-potential entrepreneurship, and in offering gender-neutral entrepreneurship education across all areas of the curriculum. The design of welfare systems equally has critical impacts on women's entrepreneurship. 


\section{References}

Blomquist, M. et al. (2014), Bridging the Entrepreneurship Gender Gap: The Power of Networks, Boston Consulting Group, Boston.

Brush, C., N. Carter, E. Gatewood, P. Greene, and M. Hart (2004), Clearing the Hurdles: Women Building High-Growth Businesses, Upper Saddle River, NJ: Prentice Hall.

Carter, S. et al. (2007), "Gender, Entrepreneurship, and Bank Lending: The Criteria and Processes Used by Bank Loan Officers in Assessing Applications", Entrepreneurship Theory and Practice, Vol. 31, No. 3, pp. 427-444.

Coleman, S. and A. Robb (2014), Access to Capital by High-Growth Women-Owned Businesses, Report prepared for the National Women's Business Council, National Women's Business Council, Washington, DC.

Eurostat (2020), Labour Force Survey, https:/lec.europa.eu/eurostat/web/lfs/data/database.

Facebook/OECD/World Bank (2020), "The Future of Business Survey", https://dataforgood.fb.com/wpcontent/uploads/2020/10/State-of-Small-Business-Report-Wave-IV.pdf.

Global Entrepreneurship Monitor (GEM) (2020), "Global Entrepreneurship Monitor 2019/2020 Global Report”, https://www.gemconsortium.org/report/gem-2019-2020-global-report.

Marlow, S. and M. McAdam (2013), "Gender and Entrepreneurship: Advancing Debate and Challenging Myths - Exploring the Mystery of the 'Under-performing' Female Entrepreneur", International Journal of Entrepreneurial Behaviour and Research, Vol. 19, pp. 114-124.

Marlow, S. and D. Patton (2005), "All Credit to Men? Entrepreneurship, Finance and Gender," Entrepreneurship Theory \& Practice, pp. 717-735.

OECD (2020), COVID-19 Policy Brief on Well-being and Inclusiveness, http://www.oecd.org/coronavirus/en/.

OECD (2020), Self-employed without employees (indicator), doi: 10.1787/5d5d0d63-en (accessed on 1 December 2020).

OECD (2020), Self-employed with employees (indicator), doi: 10.1787/b7bf59b6-en (accessed on 1 December 2020).

OECD (2017), The Pursuit of Gender Equality: An Uphill Battle, OECD Publishing, Paris, http://dx.doi.org/10.1787/9789264281318-en.

OECD (2016), Entrepreneurship at a Glance 2016, OECD Publishing, Paris, http://dx.doi.org/10.1787/entrepreneur aag-2016-en.

OECD (2012), Closing the Gender Gap: Act Now, OECD Publishing, Paris, http://dx.doi.org/10.1787/9789264179370-en.

OECD/EU (2019), The Missing Entrepreneurs 2019: Policies for Inclusive Entrepreneurship, OECD Publishing, Paris, https://doi.org/10.1787/3ed84801-en.

OECD/EU (2018), "Policy Brief on Women's Entrepreneurship", OECD SME and Entrepreneurship Papers, No. 8, OECD Publishing, Paris, https://doi.org/10.1787/dd2d79e7-en.

OECD/EU (2015), "Entrepreneurial Activities in Europe - Expanding Networks for Inclusive Entrepreneurship", OECD Employment Policy Papers, No. 7, OECD Publishing, Paris, https://doi.org/10.1787/5jirtpbz29mih-en. 
Ogbor, J. (2000), "Mythicizing and Reification in Entrepreneurial Discourse: Ideology Critique of Entrepreneurial Studies," Journal of Management Studies, Vol. 37, No. 5, pp. 605-635.

Saridakis, G., S. Marlow and D. Storey (2014), "Do Different Factors Explain Male and Female Selfemployment Rates?", Journal of Business Venturing, Vol. 29, No. 3, pp. 345-362.

Uzzi, B. (1999), "Embeddedness in the Making of Financial Capital: How Social Relations and Networks Benefit Firms Seeking Financing," American Sociological Review, Vol. 64, pp. 481-505. 
Part II International policy insight notes 


\section{Fostering a gender-sensitive entrepreneurship culture}

Increasing awareness about the potential of entrepreneurship among women is an important first step to advancing entrepreneurship for all. This chapter discusses policy approaches to creating a more gender-sensitive entrepreneurship culture, including awareness campaigns, role models and developments in the education system. This discussion is illustrated by six policy insight notes from Australia, Germany, India, Iran, Turkey and the United Kingdom. Each note presents and assesses a current policy debate. The chapter draws out lessons from the country perspectives. 


\section{Creating a positive image of women entrepreneurs}

Despite the advances made in women's social and economic participation, negative gender stereotypes persist, and gender gaps remain (OECD/EU, 2018). A range of subtle barriers (e.g. gender role assumptions) continue to have negative impacts on gender equality in the labour market, including both employment and self-employment.

Entrepreneurship has long been considered a "masculine" phenomenon and this has been sustained by social and cultural attitudes and norms (Hamilton, 2013). Consequently, women's entrepreneurship is considered to have a lower level of legitimacy (Ogbor, 2000), which impedes access to resources, such as human, financial and social capital (Brush et al., 2004) and prevents the full realisation of women's entrepreneurial potential (Marlow and Patton, 2005). Equally as important, the prevailing social and cultural attitudes around gender roles can lead to women self-restricting their business and entrepreneurship activities to certain sectors or professions, and reducing their growth ambitions.

One way that social attitudes are visible is through attitudes towards business failure. Across OECD countries, women were about $20 \%$ more likely than men to report over the period 2015-19 that a "fear of failure" prevented them from starting a business (see Chapter 2). More than half of women in Austria, Belgium, Canada, Estonia, Greece, Hungary, Israel, Italy, Latvia, Luxembourg, Poland and Portugal reported that "fear of failure" was a barrier to entrepreneurship.

\section{The role of public policy}

Public policy can serve to build a more women-friendly entrepreneurship culture by simultaneously promoting entrepreneurship to women and profiling women's entrepreneurship more broadly in society. Common approaches include promoting entrepreneurial women role models, publicising profiles of women entrepreneurs through award programmes, and ensuring that family policies support entrepreneurship. The education system also has a critical role in shaping social attitudes towards women's labour market participation and labour market activities, including entrepreneurship.

Promoting positive role models is one of the important ways in which policy can help to counteract traditional gender roles and encourage more women to consider entrepreneurship as a career. These recommendations help to address the small numbers of women who are identifiable as entrepreneurial role models and off-set stereotypes about entrepreneurs. The need to promote women entrepreneur role models is particularly important in science, technology, engineering and mathematics (STEM) fields. Women role models can increase the entrepreneurial propensity of other women through positive representation in the media, direct interactions, and through learning materials in training and education programmes (Bijedić et al., 2014).

Policy should ensure that family policies support the participation of women in the labour market, including sufficient availability of child care. Supporting a higher take-up by men of paternity and parental leave could support mothers to return to the labour market earlier and help erode stereotypical perceptions of who should assume caregiving responsibilities, both of which are institutional barriers to entrepreneurship (World Bank, 2012). Recent progress has been made in many countries, including in Iceland and Norway which have established compulsory paternity leave. In other countries, such as Sweden, a portion of parental leave is reserved for the father and is lost if he decides not to take it. Similarly, the availability of childcare (e.g. day care sites) and allowances for parents to pay for childcare can encourage women's participation in the labour market. However, very few of these measures are aimed at women entrepreneurs directly. Such supports are sometimes available to employees but not small business owners. Consequently, many such policies encourage women to become employees rather than selfemployed entrepreneurs. 
Education has an important role in influencing social attitudes towards entrepreneurship. It is important to ensure that curricula reform includes positive messages about women and work, where equal entrepreneurship educational opportunities are provided for boys and girls, and gender stereotypes in textbooks and classrooms are eliminated. There is also a need to foster young women's entrance into programmes and fields of study that are more likely to lead to entrepreneurship and to the creation of innovative, high growth firms. This requires educating women on the gaps in opportunities and earnings in different sectors, and ensuring they have opportunities to access work experiences (e.g. training, internships, mentoring programmes) in sectors that have been traditionally dominated by men.

\section{Lessons from the policy cases}

The six policy insight notes in this section cover a range of issues related to building a positive entrepreneurship culture for women entrepreneurs. They discuss strategies to create a supportive entrepreneurship culture for women entrepreneurs (Australia and Germany), ensuring that women play a greater role in innovation (United Kingdom) and the impact of broader gender issues related to labour market participation and society on entrepreneurship opportunities (India, Iran and Turkey). Together, these notes underline three lessons for public policy:

1. Success in closing gender gaps in entrepreneurship is linked to broader policy efforts to close gender gaps in society and the labour market in general. Gender roles in society can have a strong and negative influence on women's entrepreneurship. This is illustrated, for example, in the policy insight note on India, which discusses the difficulties faced by women such as harassment, and on Iran, where patriarchal norms exert a strong influence on women. The note on Turkey discusses the challenges of women's entrepreneurship that stem from a lack of access to formal education and cultural norms.

2. Family policies need to continue to evolve to support women's participation in the labour market and reduce gaps in access to supports between entrepreneurs and employees. Some countries have family support systems that reinforce traditional gender roles. These have a negative influence on women's labour market participation and entrepreneurial activities. The note on Germany, for example, argues that lack of affordable day care and single-earner income tax policies reinforce occupational roles of women as caregivers, which reduces women's entrepreneurial activities.

3. Women's entrepreneurship should be celebrated and supported with more formal and larger-scale initiatives. The policy insight notes show that women's entrepreneurship has a relatively low status in many countries. Even among top-ranked ecosystems for women's entrepreneurship, such as in the city of Melbourne, Australia, gender-sensitive supports are limited to mentorship and advocacy. Components of entrepreneurial ecosystems that are characterised by volunteerism are vulnerable to fatigue and turnover among time-stretched workers. Similarly, the note on the United Kingdom illustrates how a programme can be successful in supporting innovative businesses run by women but remains at a very small scale compared with market needs.

\section{References}

Bijedić, T., F. Maaß, C. Schröder and A. Werner (2014), “Der Einfluss institutioneller Rahmenbedingungen auf die Gründungsneigung von Wissenschaftlern an deutschen Hochschulen", IfM-Materialien No 233, Bonn.

Hamilton, E. (2013), Entrepreneurship across generations: narrative, gender and learning in family business, Cheltenham: Edward Elgar Publishing.

Marlow, S., and D. Patton (2005), "All Credit to Men? Entrepreneurship, Finance and Gender," 
Entrepreneurship Theory \& Practice, pp. 717-735.

OECD/EU (2018), "Policy Brief on Women's Entrepreneurship", OECD SME and Entrepreneurship Papers, No. 8, OECD Publishing, Paris, https://doi.org/10.1787/dd2d79e7-en.

Ogbor, J. (2000), "Mythicizing and Reification in Entrepreneurial Discourse: Ideology Critique of Entrepreneurial Studies," Journal of Management Studies, Vol. 37, No. 5, pp. 605-635.

World Bank (2012), Global Financial Development Report 2013: Rethinking the Role of the State in Finance, Washington. 


\title{
Australia
}

\author{
By Patrice Braun, Federation University Australia \\ Naomi Birdthistle, Griffith University \\ Antoinette Flynn, University of Limerick
}

\section{Background}

Australia is the world's sixth largest land mass (World Atlas 2020). With over 25 million people (Worldometer, 2020), Australia is ranked fifth among OECD countries for population growth, and among the least densely populated countries in the world (United Nations, 2019). Most of the population congregates along coastal lines, although there are regional towns and rural communities spread throughout the Australian outback. Australia's Indigenous population, Aboriginal and Torres Strait Islander people represent $3.3 \%$ of the total population, $1.5 \%$ of which live in remote or very remote areas (AlHW, 2019).

Australia is often referred to as the "lucky country" with a highly developed, high-income economy and uninterrupted economic growth over the past three decades, yet economic growth has not been inclusive. Women are less likely to be in the paid workforce, more likely to work part-time, earn less per week; and retire with less superannuation, compared to men (OECD, 2017). Despite Australia's adoption of gender transparency measures, the gender pay gap remains at $13.9 \%$ (WGEA, 2020) with Australia's ranking slipping from $39^{\text {th }}$ to $44^{\text {th }}$ according to the Global Gender Report (Bosma et al., 2020).

Entrepreneurship is a means to close gender gaps, as evidenced by the fact that women lead $34.8 \%$ of Australian businesses (Australian Government Department of Skills, Education and Employment, 2019). In terms of early stage entrepreneurship, $9.2 \%$ of female adults are involved in start-ups, compared to $15.3 \%$ of males (Steffens and Omarova 2019). Total Entrepreneurial Activity (TEA) ${ }^{1}$ by gender indicates that female TEA is improving at $8.8 \%$. However, TEA remains substantially below the rates for males (12.3\%) (Moyle et al., 2020). At the same time, there has been a rise in the number of Indigenous business owners in the last decade (close to $72 \%$ ), with women Indigenous business operators increasing from $7.6 \%$ in 2006 and women-owned incorporated enterprises increasing by $8.2 \%$ (Zuchetti, 2018).

\section{Policy issue: Building a pipeline of women entrepreneurs}

Australian entrepreneurs are more likely to be motivated by opportunity than necessity, with women indicating that they seek to make a difference $(54.9 \%)$ or build wealth $(51.1 \%)$ over making a living $(37 \%)$ (Bosma et al., 2020). Even though Australia ranks 14th in the World Bank, the Ease of Doing Business Index and entrepreneurial ecosystems are maturing, yet public policies and capacity for entrepreneurship remain constraining factors (Bosma et al., 2020). Australia has "a poor pipeline" to entrepreneurship for women as "there is a gender imbalance in the rate of start-ups" (Steffens and Omarova, 2019). A good pipeline to entrepreneurship is, inter alia, when women engage in start-up at the same rate as men, and are as confident that they have the skills to start a business (Aidis and Weeks, 2016).

Australian women entrepreneurs suffer from a lack of connectedness to the start-up ecosystem (Australian Government Department of Industry, Innovation and Science, 2018). In mapping and comparing metropolitan and rural entrepreneurial ecosystems through consultations with enterprising women and service providers, Eversole et al. (2019) confirm that while enterprise supports (e.g. mentoring, advice, training, finance and peer networks) are obtainable, there are issues with accessibility, take-up and appropriateness of resources for women in Victoria and Tasmania. Financial inclusion being crucial for women, the research found a narrow range of financial supports, with a perceived "marked absence of 
women-specific financial supports" (Eversole et al., 2019: pp. 72). Women in rural areas in particular lacked access to enterprise incubation and acceleration supports, including access to formal support networks. As such, ecosystem supports were deemed to be inadequate and gender-insensitive, and failed to meet the start-up and business needs of enterprising women in diverse geographic settings. Observations suggest the talent-pipeline of women entrepreneurs is insufficient and the Australian start-up ecosystem can be improved.

Acknowledging that women-led start-ups encounter higher barriers to success than their men counterparts due to limited access to capital, networks and resources, in 2018 the Australian Government invested AUD 18 million in the Boosting Female Founders (BFF) financial support initiative (Australian Government Department of Industry, Innovation and Science, 2018). Over three years (2020-23), BFF will match funding investment schemes that seek to stimulate private sector investment in innovative start-ups led by women, and to launch, scale and expand their firms in domestic and global markets (Australian Government Department of Industry, Innovation and Science, 2018). Designed to boost the economy by increasing the diversity of start-up founders, the programme purposively targets Indigenous peoples, migrant, refugee and disabled women entrepreneurs. Given the unconscious bias women often face raising investment capital (Australian Government Department of Industry, Innovation and Science, 2018), it remains to be seen to what extent this programme will increase opportunities for women-led start-ups.

\section{Conclusions and recommendations}

While Australia has a comprehensive small and medium-sized enterprise (SME) ${ }^{2}$ agenda aimed at improving the business operating environment (OECD, 2019), it maintains an ad hoc approach to supporting women entrepreneurs. BFF is the only women-focused entrepreneurship investment fund of its kind. The Australian Government does not support gender-responsive policies such as public procurement for women entrepreneurs, although in 2015 it did initiate an Indigenous procurement policy that provides increased opportunities and growth for Indigenous entrepreneurs (NIAA, 2015).

Nor does Australia collect sex-disaggregated small business census, SME policy or programme data. With women entrepreneurs being under-represented in the Australian start-up ecosystem (Australian Government Department of Industry, Innovation and Science, 2018), there is a clear need to develop more holistic programmes and measures to support women's talent. Based on international benchmarks and Australia's talent pipeline performance for women entrepreneurs, the following policy recommendations are advanced.

\section{Recommendations for Australia}

- Unlock the potential of Australian women by designing inclusive supports that build entrepreneurial capacity and strengthen the talent-pipeline of women entrepreneurs.

- Acknowledge that Australian women entrepreneurs are a heterogeneous group located across diverse geographic locations and start-up ecosystems, requiring targeted development approaches and supports.

- Increase and widen gender-responsive start-up programmes that boost and measure women entrepreneurs' participation rates, including access to resources, financial supports, public procurement, and collection of gender-disaggregated data. 


\section{References}

Aidis, R. and J. Weeks (2016), "Mapping the gendered ecosystem: The evolution of measurement tools for comparative high-impact female entrepreneur development", International Journal of Gender and Entrepreneurship, Vol.8/4, pp. 330-352.

Australian Bureau of Statistics (2002), 1321.0 - Small Business in Australia, 2001, https://www.abs.gov.au/ausstats/abs@.nsf/mf/1321.0 (accessed 12 June 2020).

AlHW (2019), Australian Government. Australian Institute of Health and Welfare. Profile of Indigenous People, https://www.aihw.gov.au/reports/australias-welfare/profile-of-indigenous-australians (accessed 28 May 2020).

Australian Government Department of Industry, Innovation and Science (2018), Boosting Female Founders Initiative Discussion Paper, https://consult.industry.gov.au/science-commercialisation/bff design/supporting documents/ BoostingFemaleFoundersDiscussion Paper.pdf (accessed 3 June 2020).

Australian Government Department of Education, Skills and Employment (2019), A statistical snapshot of women in the Australian workforce, Australia, https://www.employment.gov.au/ newsroom/statisticalsnapshot-women-australian-workforce, (accessed 1 June 2020).

Bosma, N., S. Hill, A. Ionescu-Somers, D. Kelley, J. Levie and A. Tarnawa (2020), Global Entrepreneurship Monitor: 2019/2020 Global Report, Global Entrepreneurship Research Association: London Business School: London, https://www.gemconsortium.org/report.

Eversole, R., N. Birdthistle, M. Walo and V. Godinho (2019), "Towards a typology of supports for enterprising women: A comparison of rural and urban Australian regions”, in High-growth Women's Entrepreneurship: Programs, Policies and Practices, Edward Elgar.

Moyle, C., R. Torres de Oliveira, T. Nguyen and C. Renando (2020, in press), Global Entrepreneurship Monitor Australian Population Survey-Trend Analysis, Australian Centre for Entrepreneurship Research, QUT.

NIAA (2015), National Indigenous Australians Agency, Indigenous Procurement Policy, Australia Government, https://www.niaa.gov.au/resource-centre/indigenous-affairs/indigenous-procurementpolicy-overview (accessed 29 May 2020).

OECD (2019), OECD SME and Entrepreneurship Outlook 2019, OECD Publishing, Paris, https://doi.org/10.1787/34907e9c-en.

OECD (2017), The Pursuit of Gender Equality: An Uphill Battle. OECD Publishing, Paris, https://doi.org/10.1787/9789264281318-en.

Steffens, P. and A. Omarova (2019), Global Entrepreneurship Monitor (GEM): 2017/18 Australian National Report, The University of Adelaide: Adelaide.

United Nations (2019), World Population Prospects 2019, https://population.un.org/wpp/ (accessed 29 May 2020).

WGEA (2020), Australian Government Workplace Gender Equity Agency. Australia's Gender Pay Gap Statistics, https://www.wgea.gov.au/data/fact-sheets/australias-gender-pay-gap-statistics (accessed 29 May 2020).

Worldometer (2020), Australia Population, https://www.worldometers.info/world-population/australiapopulation/ (accessed 29 May 2020).

World Atlas (2020), The Largest Countries in the World, World Atlas. https://www.worldatlas.com/articles/the-largest-countries-in-the-world-the-biggest-nations-asdetermined-by-total-land-area.html (accessed 29 May 2020).

Zuchetti, A. (2018), "Number of Indigenous, female business owners surge", My Business, https://www.mybusiness.com.au/management/4148-number-of-indigenous-female-business-owners-surge (accessed 29 May 2020). 


\section{Notes}

1 Total Entrepreneurial Activity (TEA) is the proportion of the working-age adult population actively engaged in starting or running a business which has been operating for between 3-42 months (Bosma et al., 2020).

2 In Australia, a small enterprise is defined as a business with less than 20 employees, and a mediumsized enterprise has between 20 and 199 employees (Australian Bureau of Statistics, 2002). 


\section{Germany}

By Friederike Welter, University Siegen and IfM Bonn

\section{Background}

Between 2007 and 2018, the number of women entrepreneurs in Germany increased by $6.1 \%$ (from 1.25 million to 1.33 million) while the number of men entrepreneurs decreased by $1.8 \%$ to 2.6 million (IfM Bonn, 2020). In 2018, women entrepreneurs made up $6.8 \%$ of the total women's labour force, compared to $12.0 \%$ for men (IfM Bonn, 2020).

Women tend to pursue different forms of labour market participation and entrepreneurship than men. Many women, predominately in West Germany, prefer part-time employment, whether as waged or selfemployed work. Women are more likely than men to be hybrid entrepreneurs (i.e. move between selfemployment and waged employment or periods of non-employment, or be simultaneously self-employed and wage-employed) (Suprinovic, Schneck and Kay, 2016). Moreover, women-led firms are less likely to carry out technology-based innovations, although the share of women entrepreneurs in knowledgeintensive professions and innovative sectors is growing (Kay and Günterberg, 2019). This is likely partly due to tax regulations and family policies which reinforce implicit traditional cultural norms on the occupational role of women. This may prevent more women from entering the labour market, setting up or growing their own businesses, and entering non-traditional sectors.

\section{Policy issue: How to change traditional gender role models}

Germany has an established regulatory environment for entrepreneurship, yet some economic policies implicitly favour a traditional gender role model and promote entrepreneurship as a less desirable career choice for women (Welter, 2006), thus reinforcing conservative family norms (OECD, 2016). For example, the spousal splitting system favours married couples with one primary bread winner with a high income (traditionally the man in heterosexual couples) and one (part-time) employed person with a lower income which is primarily responsible for household and family duties (mostly the woman due to work-time and industry preferences, and the gender pay gap). The tax model, therefore, reinforces traditional gender patterns of men working and women staying at home. It is estimated that if Germany were to tax the individual incomes of married couples, the labour market participation of women (including selfemployment) would increase by 2.4 percentage points, and their average working hours by 7.4 percentage points (Bach et al., 2011).

Family policies compound normative institutions, as they impact women's ability to reconcile family obligations with employment, as employees or entrepreneurs. For example, although progress has been made in recent years, there is still a lack of public day care for children. Since 2013, the state has committed to providing day care for every child between the ages of one and three years. Despite this, in 2018, only $33 \%$ of children under 3 years old were in day care (BMFSFJ, 2019). There were substantial regional variations, with these figures reaching nearly $60 \%$ in some of the East German states. To some extent this may still reflect former socialist gender norms that fostered women's labour market participation, facilitating this through a comprehensive state child care system. Interestingly, the impact this may have had on women's entrepreneurship in the early years after reunification (Welter, 2006a) seems to have decreased over time, with women self-employment quotas in West and East Germany converging (IfM, 2020). Furthermore, the opening hours of childcare facilities are more favourable in East Germany compared to the Western part of Germany (BMFSFJ, 2019): 87\% (57\%) of facilities in East (West) Germany open early (before $7.30 \mathrm{am}$ ), and only $8 \%(44 \%)$ close early (at $4.30 \mathrm{pm})$. In addition, social benefits oftentimes continue to favour men as breadwinners. This is true of the initial schemes offering benefits for families and childcare. The basic parental leave scheme "Elterngeld" ("parental allowance") favours women staying at home: it allocates 12 months of parental leave financial support to one partner (mostly women) and an 
additional 2 to the other (mostly men). More recent family policies such as "ElterngeldPlus" ("parental allowance plus", which offers higher financial support if coupled with part-time work during parental leave time) or the "Partnership Bonus" (offers an additional two months financial support if both partners equally split their parental leave months), both also applicable to (women) entrepreneurs, aim at fostering a more equal distribution of parental leave between men and women.

Although women's employment and entrepreneurship are accepted widely, German society implicitly continues to perceive entrepreneurship as something that is predominately undertaken by men, and women entrepreneurs are an exception to this norm (Welter, 2006b). Women are still predominately responsible for combining work and family responsibilities rather than sharing them with men (BMFSFJ, 2019). Indeed, where "women feel that employment is incompatible with being a good mother, they may feel considerable role-conflict and strain" (Sjöberg, 2004, p. 111), and as a consequence, they refrain from entering the labour market and setting up their own business. Hence, it is not only the lack of day care facilities that hinders women's entrepreneurship but also the implicit understanding that women still are the main carers in the family. Although over the past decades, women have come to spend less time on household tasks, recent research still shows a marked gender difference with regard to the distribution of paid work (which men pursue for more hours than women) and unpaid work at home and in the family (which is mainly incurred by women) (Samtleben, 2019).

Studies analysing the images of women entrepreneurs as represented in the German public media (for example, newspapers) show how traditional role models are reinforced by positioning the work-family balance as a "women-only" topic (Ettl, Welter and Achtenhagen, 2016), and by showing women entrepreneurs as mothers first, and entrepreneurs second, with entrepreneurial success subordinated to the image of a good family person (Achtenhagen and Welter, 2011). In the past, Germany has introduced a number of programmes or other means that promote women entrepreneurs as role models. For example, in the "FRAUEN.unternehmen" ("Women Entrepreneurs") initiative, women entrepreneurs mentor young girls and women, including a series of workshops and meetings around the theme "StarkeFrauen - Starke Wirtschaft" (set up as a hashtag on twitter, meaning "strong women - strong economy"). These initiatives are a step forward in creating more gender-equal role models in Germany, albeit in the long-run.

\section{Conclusions and recommendations}

Much has been done at the federal level to support women's entrepreneurship. Still, traditional gender role models continue to - implicitly - promote entrepreneurship as a less desirable career choice for women; they also still underpin existing economic and family policies.

\section{Recommendations for Germany}

- Promote a gender-equal image of women in the labour market and in entrepreneurship. Current federal policy initiatives such as "Frauen.unternehmen" should be continued, scaled-up and accompanied by additional public campaigns.

- Minimise the impact of the unpaid gender care gap on women's entrepreneurship. Continually evaluate policies aimed at fostering a more equal distribution of child care through supporting parental leave to ensure that the current design motivates gender-equal child care.

- Use tax policies more effectively to support gender-equal entry into the labour market. Abolish or update the spousal splitting system for taxing spousal incomes to provide greater incentives for women's entry into the labour market. 


\section{References}

Achtenhagen, L. and F. Welter (2011), "'Surfing on the ironing board' - the representation of women's entrepreneurship in German newspapers", Entrepreneurship \& Regional Development, Vol, 23, No. 9-10, pp. 763-786.

Bach, S., J. Greyer, P. Haan and K. Wrohlich (2011), "Reform des Ehegattensplittings: Nur eine reine Individualbesteuerung erhöht die Erwerbsanreize deutlich", DIW Wochenbericht No. 41/2011, pp. 13-19.

BMFSFJ (2019), "Kindertagesbetreuung kompakt: Ausbaustand und Bedarf 2018", Berlin, https://www.bmfsfi.de/blob/156236/faeb6a19a33244fe91af8543db56bade/kindertagesbetreuungkompakt-ausbaustand-und-bedarf-2018-ausgabe4-data.pdf.

BMFSFJ (2019), Agenda 2030 - Nachhaltige Familienpolitik, Berlin, https://www.bmfsfj.de/blob/142626/e593258f01dcb25041e3645db9ceaa5b/agenda-2030langfassung-data.pdf.

Ettl, K., F. Welter and L. Achtenhagen (2016), "Das 21. Jahrhundert ist weiblich: Unternehmerinnen in der Presse", IfM-Materialien, No 249, Bonn: IfM Bonn.

IfM Bonn (2020), "Self-employed/liberal professions", https://www.ifmbonn.org/statistiken/selbststaendigefreie-berufe/\#accordion=0\&tab=0.

Kay, R. and B. Günterberg (2019), "Existenzgründungen von Frauen - Aktuelle Entwicklungen”, Daten und Fakten, No. 24, Bonn: IfM Bonn.

OECD (2016), "Supporting Women Entrepreneurs in Germany: Rapid Policy Assessment", http://www.oecd.org/employment/leed/Rapid-policy-assessment-Germany-final.pdf.

Samtleben, C. (2019), "Also on Sundays, Women Perform Most of the Housework and Child Care", DIW Weekly Report, Vo. 9, No. 10, pp. 86-92.

Sjöberg, O. (2004), "The Role of Family Policy Institutions in Explaining Gender-Role Attitudes: A Comparative Multilevel Analysis of Thirteen Industrialized Countries", Journal of European Social Policy, Vol 14, No. 2, pp. 107-123.

Suprinovic, O., S. Schneck and R. Kay (2016), "Einmal Unternehmer, immer Unternehmer? Selbstständigkeit im Erwerbsverlauf”, IfM-Materialien, No. 248. Bonn: IfM Bonn.

Welter, F. (2006a), "West and East German Women Entrepreneurs: (Why) Are they still different?", in Welter, F., D. Smallbone and N. Isakova (eds.), Enterprising Women in Transition Economies, Aldershot: Ashgate, pp. 171-200.

Welter, F. (2006b), "Women`s entrepreneurship in Germany: progress in a still traditional environment", in Brush, C., N. Carter, E. Gatewood, P. Greene and M. Hart (eds), Growth-oriented women entrepreneurs and their businesses, Cheltenham, UK; Northampton MA: Edward Elgar, pp. 128-153. 
India

\author{
By Roshni Narendran, University of Tasmania
}

\title{
Background
}

As in most economies, women in India women are less active in entrepreneurship than men. Out of 458.5 million entrepreneurs in 2019 , only 8.1 million are women (Startup India, 2019) and they employ 13.5 million people (Government of India, 2020). The majority of women-owned enterprises operate in the Agriculture, Manufacturing and Retail sectors (Startup India, 2019), and are under-represented in the Engineering and Construction sectors (OECD, 2017).

The National Policy for Skill Development and Entrepreneurship (Ministry of Skill Development and Entrepreneurship, 2015) has made significant contributions to promoting entrepreneurship, including supporting women entrepreneurs. A core policy objective is "to empower the individual, by enabling her/him to realise their full potential through a process of lifelong learning where competencies are accumulated via instruments such as credible certifications, credit accumulation and transfer" (p. 11). While the policy is not gender specific, it includes a section on women's entrepreneurship that refers to "women", "female" and "gender", but does not categorise women as a marginalised group. The report also focuses on castebased groups. ${ }^{1}$ While the policy advances actions targeted at the population of small- and medium-sized enterprises, it recommends the provision of gender mainstream training to increase women's participation in the workforce and entrepreneurship, and enhanced access to credit. Actions targeted at women entrepreneurs include business awards, networks and mentors (2017-18 Annual Report of the Ministry of Skill Development and Entrepreneurship).

The Indian government has developed dedicated programmes to support women entrepreneurs, such as Speed Mentoring, Cent Kalyani Scheme (loan up to INR 1 million), Women Entrepreneurship Platform (an online forum to motivate women to start businesses, foster entrepreneurial activities and provide handson supports to establish and scale a business), Iccha Shakti to motivate start-up, and Gyaan Shakti to provide knowledge and ecosystem support to women entrepreneurs (see https://wep.gov.in).

The under-representation of women in entrepreneurship highlights important gaps within policy and programming. One gap is the failure to address the safety of women entrepreneurs.

\section{Policy issue: Women entrepreneurs' personal safety}

Entrepreneurship policy in India focuses mainly on skill development through training and education. Most policies stress the need to provide women with the skills required to engage in industries or sectors not traditionally embraced by women. There is an emphasis on the need to increase gender sensitivity, which in turn, encourages women to actively participate in the workforce. While the National Policy for Skill Development and Entrepreneurship refers to "gender sensitivity" in the workplace, the policy does not clearly define the term. The term appears to draw attention to the gap in labour force participation between genders. The term also references "gender sensitive training environment" (p. 33) yet a clear definition is not provided. It can be assumed that the training includes programmes to ensure gender equality. The lack of clarity highlights particular aspects of the workplace of women entrepreneurs which pose risks, such as harassment. This deters women's entrepreneurship and hinders the development of women-led businesses.

Unequal treatment of women and increasing harassment discourage many women from becoming entrepreneurs. India is a patriarchal society, where cultural norms dictate women's social roles and imply hierarchical relations between men and women (Nieder, Muck and Kärtner, 2019). These, in turn, lead to increased crimes against women (Ministry of Home Affairs, 2016; Nigam, 2017). In India, women's safety is a major concern, with sexual harassment in public places posing a problem for women who travel 
(Bharucha and Khatri, 2018). Women entrepreneurs need to travel to obtain relevant licenses, and to acquire customers, funds and inventory. Given concerns about safety and security, including the need to circumvent harassment in public places, questions arise about how women entrepreneurs can take advantage of skill development training programmes.

These circumstances render many entrepreneurship policies and programmes redundant. For example, a survey of 550 experts finds that India is one of the most dangerous nations for sexual violence against women (Dewan, 2018). Figures from the National Crime Records Bureau show an increase in crime against women, with more than 41000 such crimes reported in 2016 (Ministry of Home Affairs, 2016); 2.8 cases of rape are reported every hour in India (Ministry of Home Affairs, 2016). There has been a 54\% increase in reported sexual harassment cases within four years (Watts, 2019). Over the years, there has been little change in sexual violence against women. Negotiating a new identity for women remains an impossible task (Joy, Belk and Bhardwaj, 2015). Moreover, the implementation of laws against sexual violence and harassment is uneven. It is reported that some Indian authorities abase complaints of sexual harassment from women who wear revealing outfits or approach officers without first calling on a family member to be present (Bhattacharyya, 2015). While the government, particularly the National Commission for Women, has introduced programmes to help address women's safety, harassment against women has a detrimental impact on women's entrepreneurship. This constraint needs to be an important component of all entrepreneurship policies.

Another obstacle is the widely-held perception that entrepreneurship is not an activity that is suitable for women. Many women entrepreneurs are subjected to social disapproval when engaging in business activities within male-dominated industries. Disapproval is pronounced based on one's religion, level of education or caste (a socially-constructed prenominal segregation within society) (Jaspal, 2011). Entrepreneurship policies must consider cultural factors and associated discriminations.

\section{Conclusions and recommendations}

While current policy and related programmes have advanced promising initiatives to enhance entrepreneurial activity, the social issues of gender discrimination and safety have not been addressed. Policy initiatives will become redundant if they fail to address the embedded discrimination against women. Women have reported being harassed by family and non-family members. Harassment prevents many women from pursuing entrepreneurial activities. This could be the reason why, in India, one of the world's most populated countries, only $14 \%$ of women chose to become entrepreneurs. And despite the existence of agencies to address harassment against women, harassment issues need to be embedded in policies, such as the National Policy for Skill Development and Entrepreneurship. The following recommendations are offered to policy makers seeking to enhance women's participation in entrepreneurship. 


\section{Recommendations for India}

- Address negative attitudes towards women entrepreneurs in communication campaigns and promote programmes empowering women to be entrepreneurial.

- Ensure that gendered entrepreneurship policies are developed in a cohesive manner and offer various supports in packages (e.g. entrepreneurship skills coupled with start-up financing).

- Enhance the safety and security of women in India to help them to engage more in entrepreneurial activities in public, and provide training to run online businesses, thereby reducing opportunities for women entrepreneurs to be harassed.

\section{References}

Bharucha, J. and R. Khatri (2018), "The sexual street harassment battle: perceptions of women in urban India", The Journal of Adult Protection, Vol. 20, No. 2, pp. 101-109.

Bhattacharyya, R. (2015), "Understanding the spatialities of sexual assault against Indian women in India", Gender, Place \& Culture, Vol. 22, No. 9, pp.1340-1356.

Bourne, K. A. and M. B. Calás (2013), "Becoming 'real' entrepreneurs: Women and the gendered normalization of 'work'”, Gender, Work \& Organization, Vol. 20, No. 4, pp. 425-438.

Dewan, A. (2018), India the most dangerous country to be a woman, US ranks 10 th in survey, https://edition.cnn.com/2018/06/25/health/india-dangerous-country-women-survey-int/index.html (accessed 6 February 2019).

Government of India (2020), "\#startupindia Women Entrepreneurship”, https://www.startupindia.gov.in/content/sih/en/women entrepreneurship.html.

Jaspal, R. (2011), "Caste, social stigma and identity processes", Psychology and Developing Societies, Vol. 23, No. 1, pp. 27-62.

Joy, A., R. Belk and R. Bhardwaj (2015), "Judith Butler on performativity and precarity: Exploratory thoughts on gender and violence in India", Journal of Marketing Management, Vol. 31, No. 15-16, pp.1739-1745.

Ministry of Home Affairs (2016), "Crime in India", http://ncrb.gov.in/StatPublications/CII/CII2016/pdfs/Crime\%20Statistics\%20-\%202016.pdf (accessed 27 February 2019).

Ministry of Skill Development and Entrepreneurship (2015), "National Policy for Skill Development and Entrepreneurship", https://www.msde.gov.in/assets/images/Skill\%20India/National\%20Policy\%20on\%20Skill\%20Develop ment\%20and\%20Entreprenurship\%20Final.pdf (accessed 22 February 2019).

Ministry of Statistics and Programme Implementation (2019), "Women and Men in India", http://www.mospi.gov.in/sites/default/files/publication reports/Women and Men 31 \%20Mar 2020.p df (accessed 28 March 2020).

Nieder, C., C. Muck and J. Kärtner (2019), "Sexual violence against women in India: daily life and coping strategies of young women in Delhi", Violence against women, Vol. 25, No. 14, pp. 1717-1738.

Nigam, S. (2017), "Fighting for the Justice in the Patriarchal Courts," https://ssrn.com/abstract=3028829 (accessed 27 February 2019).

OECD (2017), The pursuit of Gender Equality: AN Uphill Battle, OECD Publishing, Paris, https://doi.org/10.1787/9789264281318-en (accessed 15 July 2019). 
Startup India (2019), "Women Entrepreneurship", https://www.startupindia.gov.in/content/sih/en/women entrepreneurship.html (accessed 17 July 2019).

Watts, K. (2019), "Sexual harassment in India: A crisis", https://www.healthissuesindia.com/2019/10/30/sexual-harassment-in-india-a-crisis/ (accessed 28 March 2020).

\section{Note}

1 The Government of India has a legal obligation to support the welfare of the most disadvantaged groups. Marginalised groups referred to in the policy document are defined by the caste-based divisions prevalent in India. These include official classifications of the population, such as Schedule Castes, Schedule Tribes and Other Backward Classes. 


\section{Background}

Women comprise almost half of Iran's 83 million population (United Nations, 2019). In the last decade, women's enrolment in Iranian universities has outnumbered that of men, yet women graduates are $33 \%$ less likely than men to find paid employment. Marriage and maternity further decrease women's employment opportunities (Saleh-Isfahani, 2008; OECD, 2017). While restricted career mobility may lead women to choose entrepreneurship, business ownership is not a level playing field for Iranian women. While there are no laws explicitly preventing Iranian women from starting a business, women's entrepreneurship is restricted by the institutional environment, including social norms, values and family obligations (Bruton, Ahlstrom and Li, 2010).

\section{Policy issue: The institutional environment}

Following the Islamic Revolution in Iran in 1979, women's contribution to the economy has centred on their roles as the cornerstones of families, with social norms emphasising the virtues of child-rearing and being "a good wife." In Iran's regime, where principles of Sharia law ${ }^{1}$ rule, men are considered the breadwinners within their immediate families, while wives or daughters are responsible for the household. Women's participation in the paid economy is considered unnecessary and secondary to that of men. This largely explains the low level of women's participation in formal economic activities. Iran ranks $147^{\text {th }}$ among 153 countries with regard to women's engagement in economic activities (World Economic Forum, 2020).

From a legal perspective, an Iranian woman's "custody" is transferred from her father to her husband upon marriage (World Bank Group, 2016). A single woman must obey her father, and a married woman is obliged to obey her husband. This concept is referred to as "Tamkin" in Arabic. ${ }^{2} \mathrm{~A}$ woman also has to obtain her legal guardian's ${ }^{3}$ (written or verbal) permission to engage in activities outside the home, including studying, travelling and engaging in occupations based solely on the guardian's discretion (Kokabisaghi, 2018; Human Rights Watch, 2017; Moghaddam, 2004). Such legal requirements can severely damage women's engagement in entrepreneurial activities, particularly in instances when her husband or father does not grant permission to set up a business. A woman entrepreneur interviewed in a recent study explained the restrictions imposed upon her soon after she got married:

"During the year we were engaged, he [my husband] had seen how my business worked. He knew that my clients were all over Iran and that I had to travel a lot. After we got married, he told me "now that we have become serious, you should obey me." After we got married, both he and his family told me: "Those ambitions were good as long as you were single. Now that you are married, your husband comes first and then your job; first your husband and then your education" (Simarasl, Pandey and Mathias, 2019).

Women's entrepreneurship is also restricted by societal norms that do not value their engagement in economic activity (Chamlou, 2008). Widespread unfavorable sexist attitudes towards women entrepreneurs, particularly among men, are among the key challenges for women running businesses. For instance, Simarasl et al. (2019) cite a serial woman entrepreneur whose loan request was declined when she was referred to a government support organisation: "When they asked me what I wanted to do with the loan, I told them that I wanted to build a concrete manufacturing facility. The men in that organisation all laughed at me and told me that, instead, I should get a sewing machine and make money with that. They refused to give me a loan." Another common obstacle facing Iranian women entrepreneurs, particularly nascent entrepreneurs, is the attitudes of landlords or real estate agents when women seek 
rental offices for their businesses. A former woman entrepreneur, who closed down her business due to the hardships she encountered, reported: "As soon as the landlord realised that I wanted to sign the lease, he said "I do not sign a lease with a woman" (Simarasl et al., 2019).

Following recent changes in the national entrepreneurship ecosystem, including the rise of e-commerce, the emergence of business angel networks and venture capitalists, and an increase in entrepreneurship training programmes and advisory services offered by the government, universities and other educational institutions (Davari and Najmabadi, 2018; Jozi, 2015), some efforts have been made to promote women's entrepreneurship. For example, in 2017, the non-profit, non-governmental organisation - the Entrepreneurship Development Foundation for Women and Youth - launched the My Business Path initiative aimed at promoting entrepreneurial activities among women and youth. This national-level initiative has been supported by the Vice Presidency of Women and Family Affairs, ${ }^{4}$ and has been implemented in a number of provinces in Iran. It aims at identifying aspiring entrepreneurs among youth and women, providing them with entrepreneurship training, consultation and mentorship, and take them through the process of turning their business ideas into feasible ventures in underserved provinces in Iran (Entrepreneurship Development Foundation for Women and the Youth, 2020).

\section{Conclusions and recommendations}

Although foundational laws and societal norms in Iran are unfavourable for women's entrepreneurship, initiatives such as My Business Path have the potential to increase women's involvement in entrepreneurship over time. While changing a country's institutional environment, especially societal norms and values, takes time, the following recommendations are offered to policy makers who seek to create institutional environments that are favourable towards women's engagement in business ownership.

\section{Recommendations for Iran}

- Amend Iran's civil laws in ways that ensure women's pursuit of education, careers (including entrepreneurship) and mobility rights (which are critical to women's entrepreneurship) are not undermined by their male guardian's will.

- Promote women's entrepreneurship via different national media (i.e. national television, etc.) by recognising accomplished women entrepreneurs, their challenges, and their successes.

- Familiarise all members of society (men and women) with the importance of women's entrepreneurship from early childhood, for instance by including stories about successful women entrepreneurs in school textbooks.

- Assign advocates for women's entrepreneurship within business support organisations to promote legal change and to champion women entrepreneurs in their efforts to raise capital, access mentorship and obtain business permits without gender discrimination.

\section{References}

Bruton, G. D. et al. (2010), "Institutional theory and entrepreneurship: Where are we now and where do we need to move in the future?", Entrepreneurship Theory and Practice, Vol. 34, No. 3, pp. 421-440.

Chamlou, N. (2008), "The environment for women's entrepreneurship in the Middle East and North Africa," The World Bank Publishing, Washington, DC., www.siteresources.worldbank.org.

Davari, A. and A. D. Najmabadi (2018), "Entrepreneurial ecosystem and performance in Iran" in Entrepreneurship Ecosystem in the Middle East and North Africa (MENA), Springer International Publishing AG, Switzerland. 
Entrepreneurship Development Foundation for Women and the Youth (2018), My business Path, www.foundationed.ir (accessed 5 April 2019).

Human Rights Watch (2017), "It's a men's club”, https://www.hrw.org/report/2017/05/25/its-mensclub/discrimination-against-women-irans-job-market\# (accessed 24 June 2020).

Jozi, A. (2015), "15 Challenges of Iran's Startup Ecosystem”, http://techrasa.com/2015/12/25/15challenges-of-irans-startup-ecosystem/ (accessed 24 June 2020).

Kokabisaghi, F. (2018), "The role of the male guardian in women's access to health services in Iran," International Journal of Law, Policy and the Family, Vol. 32, No. 2, pp. 230-249.

Merriam-Webster (2020), https://www.merriamwebster.com/dictionary/sharia?utm campaign=sd\&utm medium=serp\&utm source=isonld (accessed 22 June 2020).

Moghadam, V. M. (2004), "Women in the Islamic Republic of Iran: Legal status, social positions, and collective action", paper presented at the Iran After 25 Years of Revolution: A Retrospective and a Look Ahead conference at the Woodrow Wilson International Center for Scholars, www.wilsoncenter.org (accessed 23 June 2020).

OECD (2017), The Pursuit of Gender Equality: An Uphill Battle, OECD Publishing, Paris, https://doi.org/10.1787/9789264281318-en.

Salehi-Esfahani, D. (2008), "Are Iranian women over-educated?", Brookings Institution, https://www.brookings.edu (accessed 5 April 2019).

Shahidian, H. (2002), Women in Iran: Emerging Voices in the Women's Movement, Greenwood Publishing Group, Connecticut.

Simarasl, N., S. Pandey and B.D. Mathias (2019), "A Study of Network Blockages and Effective Entrepreneurial Strategies", Academy of Management Conference, Boston, MA, USA.

United Nations, Department of Economic and Social Affairs, Population Division (2019), World population prospects 2019 (database), https://population.un.org/wpp/DataQuery (accessed 21 June 2020).

World Economic Forum (2020), Global gender gap report (database), http://www3.weforum.org/docs/WEF GGGR 2020.pdf (accessed 20 June 2020).

\section{Notes}

${ }^{1}$ Sharia laws are "the religious laws based on the Koran that Muslims follow" (Merriam-Webster, 2020).

${ }^{2}$ Although Farsi is the official language in Iran, due to dominance and influence of Islam on Iranian civils laws, Arabic terms are widely used in legal documents.

${ }^{3}$ According to Islam, a single woman's legal guardian is her father, and a married woman's guardian is her husband (Kokabisaghi, 2018).

${ }^{4}$ Vice presidency for Women and Family Affairs is an agency under the Executive Office of President of the Islamic Republic of Iran. 


\section{Turkey}

By Duygu Uygur, Istanbul Bilgi University

Elif Bezal Kahraman

\section{Background}

Women in Turkey make a significant contribution to the economy, accounting for $33.2 \%$ of the labour force (TURKSTAT, 2018) and 7.5\% of entrepreneurs (MIWE, 2018). Despite these contributions, a stark gender gap exists in wage levels and labour force participation, dynamics that are more pronounced in Turkey than in other OECD countries. These gaps are further exacerbated by regional disparities in GDP per capita, disposable income levels and employment rates (OECD, 2018).

More than $16 \%$ of women in Turkey have a higher education qualification compared to $21 \%$ of men (this equates to $32 \%$ of women and $31 \%$ of men in the age group of $25-34$, whereas the OECD average is $50 \%$ of women and $38 \%$ of men in the same group) (TURKSTAT, 2017; OECD, 2018a). Higher education is an influencing factor for women with regard to becoming employers. For example, university education has been shown to increase the likelihood of an individual becoming an entrepreneur by a factor of eight for men and 29 for women (Okten, 2015). Data from twelve regions within Turkey show that the highest education levels can be found in Western Anatolia and the lowest in the South-eastern region. Regional entrepreneurship maps of Turkey show both the Western Anatolia and South-eastern regions to have the highest entrepreneurship index, however, a smaller number of women entrepreneurs are present in these regions (Karadeniz, 2014). This may be due to the fact that women represent $76 \%$ of unpaid family workers in Turkey; $90 \%$ of these women work on family farms mostly in rural areas in the South-eastern region. In urban areas, such as Western Anatolia, women are less likely to become employers compared to men. Urban areas, where there are more and larger firms, offer a greater number of paid employment opportunities. Women who are relatively risk averse can find jobs with a regular salary rather than starting their own business. This indicates the strong competition imposed by these larger firms, and puts women employers with small firms in a disadvantaged position (Okten, 2015). The caregiver role and related duties attributed to women in all regions are other important factors that inhibit their capacity to participate in the labour force (KSGM, 2018a; KSGM, 2018b). Accordingly, being a woman significantly decreases the probability of being an entrepreneur in both rural and urban areas.

The adoption of information and communication technologies is also a challenge, given that just $50 \%$ of Turkish women use computers, and only 65\% use the Internet (TURKSTAT, 2019). While women are reasonably well represented within STEM (science, technology, engineering and mathematics) degree programmes (where they comprise $37 \%$ of students), they account for just $10 \%$ of STEM related jobs. Willingness to take on the risk of owning a business rather than to work for someone else is above the OECD average, with $56 \%$ of men and $47 \%$ of women indicating they would start their own business (OECD Insights, 2015). This suggests that, while personal aspirations and education are influential factors, they are not strong enough to mitigate cultural norms. In this regard, some of the most important barriers to women's entrepreneurship in Turkey relate to culture, human capital and education. These include hindering gender roles and ascribed responsibilities; difficulties converting "potential" into "action" due to gender gaps in income level, financial and digital literacy, and a perceived lack of business literacy.

\section{Policy issue: Culture, human capital and education}

Women's entrepreneurship in Turkey is prioritised both in the country's 10th and 11th Development Plans set out for the periods 2014-18 and 2019-23, respectively (Presidency of Strategy and Budget, 2019). The 11th Development Plan foresees policies that provide women entrepreneurs with guidance and consultancy services for business development. Accordingly, policies include educational and financial 
supports for women entrepreneurs in both urban and rural areas of the country to strengthen the entrepreneurship culture. Digital literacy and e-commerce are to be provided to women entrepreneurs through seminars and training programmes (Presidency of Strategy and Budget, 2018)

Although policy makers acknowledge that women often have different motivations and intentions toward entrepreneurship (OECD, 2018b), and are less likely than men to be entrepreneurs, the gender gap in entrepreneurial activities has changed very little in most countries, including Turkey (OECD, 2017). Currently, Turkey's women's entrepreneurship policies focus upon vocational education; increasing the availability of care services, including those for children, the sick, people with disablities and elderly; improving regulations relating to parental equality in childcare; increasing social awareness of the factors hindering women's participation in the labour market; and the provision of entrepreneurship education, financial resources and consultancy services to women (Presidency of Strategy and Budget, 2019; KSGM, 2018b; KSGM, 2021a). While all of these policies serve to strengthen the general entrepreneurial ecosystem, they could be perceived as treating women entrepreneurs as a homogeneous group, with similar levels of education and income; they do not always consider the diversity of women's entrepreneurship, and often fail to account for differences in skill levels. They are generic policies that are not contextualised sufficiently to accommodate regional disparities, and it is difficult to determine whether they achieve their targets as there is no assessment or evaluation of results.

One example of a dedicated women's entrepreneurship support in Turkey is the Women Cooperatives, which was formally initiated by the Ministry of Trade in 2013. These organisations focus on the economic empowerment of women by promoting entrepreneurship within a support network. The Cooperatives are required to have at least seven women in order to operate, which pushes the setup and organisational responsibilities onto the women entrepreneurs themselves. Since these organisations conduct economic and social activities simultaneously, they work as self-contained and self-generating units, providing members with a support network, financial resources, training and education, access to markets and financial literacy in ways that account for local conditions (Duguid et al., 2015; Uygur and Franchini, 2019). However, these organisations also experience drawbacks, including difficulties with coordination, irresponsiveness to market changes, general image problems, bureaucracy and red tape. Despite this, Women Cooperatives offer an alternative approach to supporting women's entrepreneurship. Characterised by inclusion, a bottom-up approach, self-sustainability, flexibility and sensitivity to their local context, they have considerable potential to inspire new thinking with regard to future policy development. In 2018, the Ministry of Family, Labour and Social Services, the Ministry of Agriculture and Forestry, and the Ministry of Trade initiated "The Cooperation Protocol on Strengthening Women's Cooperatives." With regard to local applicability of the Protocol, the "Implementation Principles of the Cooperation Protocol for the Strengthening of Women's Cooperatives" was announced in the early 2020 (KSGM, 2021a). Since then, education and training workshops were conducted and work groups were formed in all 81 cities. In addition, 464 new women cooperatives have been established within the scope of this project (KSGM, 2021b).

\section{Conclusions and recommendations}

Gender roles and cultural norms continue to be acute barriers to women's entrepreneurship in Turkey. Generic policies are not effective in addressing the needs of women entrepreneurs in the different regions of the country where women have differing backgrounds and needs. Therefore, flexible policies are needed to cater for contextual variations that demand customised solutions. 


\section{Recommendations for Turkey}

- Generate policies that respond to the variety of women entrepreneurs as well as regional disparities, and that scale and customise resources according to the different aims and needs of women entrepreneurs.

- Generate women-focused entrepreneurship policies - including those related to training/education - that have clear objectives, measurable targets and specific evaluation timeframes.

- Promote and empower women's entrepreneurship, especially within women cooperatives, in all regions and in all industries by creating visibility and raising awareness. This could be achieved by establishing exclusive labels and certificates for women-owned enterprises, as well as emphasising social impact.

- Increase the promotion of social entrepreneurship as a potential activity for women entrepreneurs.

\section{References}

Duguid, F., G. Durutaş and M. Wodzicki (2015), The Current State of Women's Co-operatives in Turkey. World Bank, Washington, DC, https://openknowledge.worldbank.org/handle/10986/25977 License: CC BY 3.0 IGO.

General Directorate on the Status of Women (KSGM) (2021a), Women in Turkey, www.ailevecalisma.gov.tr/ksgm (accessed 18 April 2021).

General Directorate on the Status of Women (KSGM) (2021b), E-bülten, 5. Sayı, https://ailevecalisma.gov.tr/ksgm/duyurular/kadinin-statusu-genel-mudurlugu-e-bulten-5-sayi (accessed 18 April 2021).

General Directorate on the Status of Women (KSGM) (2018a), Women in Turkey, www.ailevecalisma.gov.tr/ksgm (accessed 18 March 2019).

General Directorate on the Status of Women (KSGM) (2018b), Kadının Güçlenmesi Strateji Belgesi ve Eylem Planı 2018-2013, https://www.ailevecalisma.gov.tr/media/6315/kad\%C4\%B1n\%C4\%B1ngue\%C3\%A7lenmesi-strajesi-belgesi-ve-eylem-plan\%C4\%B1-2018-2023.pdf (accessed 17 April 2021).

Karadeniz, E. E. (2014), “2013 ve 2014 verileriyle Türkiye'de ve Bölgelerde Girişimcilik”, GEM 2014.

Mastercard Index of Women Entrepreneurs (MIWE) (2018), https://newsroom.mastercard.com/wpcontent/uploads/2018/03/MIWE 2018 Final Report.pdf (accessed 18 March 2019).

OECD (2018a), Education at a Glance 2018: OECD Indicators, OECD Publishing, Paris, https://doi.org/10.1787/eag-2018-en.

OECD (2018b), Entrepreneurship at a Glance, 2018 Highlights, https://www.oecd.org/sdd/businessstats/EAG-2018-Highlights.pdf (accessed 3 June 2019).

OECD (2017), The Pursuit of Gender Equality: An Uphill Battle, OECD Publishing, Paris, https://doi.org/10.1787/9789264281318-en.

OECD Insights (2015), Women taking risks: closing the gender gap in entrepreneurship, http://oecdinsights.org/2015/09/29/women-taking-risks-closing-the-gender-gap-in-entrepreneurship/ (accessed 21 June 2019).

Okten Hasker, Cagla (2015). Female entrepreneurship in Turkey: patterns, characteristics, and trends 
(English). Washington, D.C.: World Bank Group. http://documents.worldbank.org/curated/en/952081479279116824/Female-entrepreneurship-inTurkey-patterns-characteristics-and-trends.

Presidency of Strategy and Budget (2019), 11th Development Plan, http://onbirinciplan.gov.tr/ (accessed 21 June 2019).

Presidency of Strategy and Budget (2018), Kadının Kalkınmadaki Rolü Özel İhtisas Raporu, https://www.sbb.gov.tr/wpcontent/uploads/2020/04/KadininKalkinmadakiRoluOzellhtisasKomisyonuR aporu.pdf (accessed 18 April 2021).

Turkish Statistical Institute (Government of Turkey), TURKSTAT (2019). http://www.tuik.gov.tr/PreTablo.do?alt id=1068 (accessed 18 March 2019).

Turkish Statistical Institute (Government of Turkey), TURKSTAT (2018), Labour Statistics, http://www.tuik .gov.tr/PdfGetir.do?id=2769 (accessed 18 March 2019).

Turkish Statistical Institute (Government of Turkey), TURKSTAT (2017), http://www.tuik.gov.tr/PreTablo.do?alt id=1018 (accessed 18 March 2019).

Uygur, D, B.Franchini European Commission (2019) Social enterprises and their ecosystems in Europe. Country fiche: Turkey, Luxembourg: Publications Office of the European Union, https://europa.eu/!Qq64ny (accessed 17 April 2021). 


\title{
United Kingdom
}

\author{
By Helen Lawton Smith, Birkbeck, University of London \\ Tim Vorley, Oxford Brookes University
}

\section{Background}

The United Kingdom (UK) launched a dedicated innovation policy for women in 2016. Innovate UK, ${ }^{1}$ the UK's Innovation agency, commissioned research to identify and assess the barriers faced by women in innovative activities, including the reasons why a disproportionately low percentage of women apply for innovation funding. The report identified barriers and made recommendations about how it could help close the gender gap.

Following that report, Innovate UK launched the "Women in Innovation" awards to showcase successful women innovators to help inspire others. In 2017, only $17 \%$ of the 2.1 million employees working in the UK's technology sector were women. ${ }^{2}$ This is consistent with the general under-representation of women in business creation and entrepreneurship (OECD/EU, 2019). Closing the gender gap in innovation and entrepreneurship represents a huge opportunity to boost the UK economy (Women's Business Council, 2018).

Key barriers to increasing the number of women engaged in innovation in the UK include a lack of awareness about innovation opportunities, a lack of mentors and champions, and access to finance. Innovation funding plays a crucial role in simulating and supporting innovation, but is often viewed by women innovators as inaccessible and male dominated. It is also often reported that funding competitions are too bureaucratic and time-consuming.

Innovate UK's Women in Innovation campaign aims to encourage women-led innovation and to help women achieve their business ambitions. The policy forms part of Innovate UK's commitment to driving sustainable economic growth through an inclusive approach to business-led innovation.

\section{Policy issue: Addressing under-representation of women in innovation}

Innovate UK aims to address several policy issues. The core challenge is how to encourage and support the participation of more women, especially given their expressed need for more substantial and focused support. Innovate UK has pursued a programme of positive action to raise awareness of and engagement with women innovators to apply for core Innovate UK funding. Consequently, an initial focus has been to raise the profile of women in innovation.

The Innovate UK initiative is competitive. Awards are given to women with exciting, innovative ideas and ambitious plans. Each award comprises GBP 50000 funding and a bespoke package of mentoring, coaching and business support. In 2019, nine of the UK's most innovative women-led businesses were awarded funding and support as part of Innovate UK's campaign to boost diversity in innovation. Innovate UK also funded an entrepreneurial mission to Boston for seven women in tech areas. This has contributed to an increase in the share of women registrations for support, from $14 \%$ to $24 \%{ }^{3}$ In 2017 , the competition was captured through an exhibition and a photography book.

A key issue for Innovate UK is the need to demonstrate additionality associated with investing public money in innovation. Promoting equality through "gender mainstreaming" can be understood as important in shifting the norms of innovation policy, and with it the innovation system. ${ }^{4}$ Innovate UK is performing an important role in raising the profile of women innovators, and making efforts to overcome the bias and barriers women encounter. However, by itself Innovate UK does not have the capacity to deliver gender 
equality and requires a wider range of stakeholders to be more active in gender mainstreaming to promote greater diversity and inclusion.

Alongside Innovate UK's work in championing gender equality, there are a number of businesses and membership organisations that recognise the need to promote and support women in business and innovation. This has resulted in a number of reports including those from the Federation of Small Business, Deloitte and Barclays Bank. However, while communicating the message, these reports fall short of positive action, and there are few actual interventions. One example of where there is direct support is through the organisation Women in Innovation. This organisation provides action-oriented programming, tangible tools and resources, with chapters in New York, London and San Francisco as well as an on-line community. Overall, while there are examples of private sector interest and initiatives, it is still early days for increasing women's participation in innovation.

\section{Conclusions and recommendations}

Innovate UK's policy of increasing the number of women innovators appears to have had some success by championing the cause of the economic and social needs for more women entrepreneurs and innovators. It has funded over 20 women innovators providing support including mentoring and finance. It has also increased visibility and hence the profile of women innovators as well as opportunities for funding. However, all this is small scale and there needs to be further coordinated action involving other interested organisations. From the UK experience, the following recommendations to policy makers are offered.

\section{Recommendations for the United Kingdom}

- Develop and extend communication programmes to put a spotlight on women in innovation to raise the awareness and the profile of innovative women entrepreneurs. This could also include doing more to promote innovative women entrepreneur champions and role models to inspire others.

- Design targeted support programmes for different demographics such as younger and older women innovators, as well as potential women entrepreneurs. These should include coaching, mentoring and training on opportunity awareness, building teams and networks, as well as financial support.

- Provide information and guidance (online) for programme officers who assess programme funding allocations that are not specifically dedicated to women entrepreneurs to ensure that women's entrepreneurship projects are assessed fairly throughout the process. The guidance should highlight unconscious biases and include the importance of monitoring and reporting key indicators such as the percentage of women-led proposals funded and the percentage of cash value.

\section{References}

Barclays Bank (2017), "Untapped Unicorns: Scaling up Female Entrepreneurship”, https://www.home.barclays/content/dam/home-barclays/documents/news/2017/Untapped-UnicornsScaling-up-Female-Entrepreneurship-2017.pdf.

Deloitte (2017), "Women Entrepreneurs: Developing Collaborative Ecosystems for Success", https://www2.deloitte.com/uk/en/pages/growth/articles/women-entrepreneurs.html.

Federation of Small Businesses (2016), "Women in Enterprise: The Untapped Potential", https://www.fsb.org.uk/docs/default-source/fsb-org-uk/fsb-women-in-enterprise-the-untappedpotentialfebc2bbb4fa86562a286ff0000dc48fe.pdf?sfvrsn=0. 
Innovate UK (2016), "Women in Innovation: Understanding Barriers to Innovation", https://www.gov.uk/government/uploads/system/uploads/attachment data/file/545202/Women In Inn ovation Ebiquity Report August 2016 FINAL.pdf.

OECD/EU (2019), The Missing Entrepreneurs 2019: Policies for Inclusive Entrepreneurship, OECD Publishing, Paris, https://doi.org/10.1787/3ed84801-en.

Women's Business Council (2018), "Maximising Women's Contribution to Future Economic Growth Five years on Progress Report 2018", https://www.womensbusinesscouncil.co.uk/wpcontent/uploads/2018/11/WBC Five Years On Report 2018.pdf.

\section{Notes}

${ }^{1}$ https://www.gov.uk/government/organisations/innovate-uk

${ }^{2}$ https://innovateuk.blog.gov.uk/2018/12/20/wanted-female-innovators-in-ai-and-data-for-programmewith-israel/

${ }^{3}$ https://www.gov.uk/government/news/women-in-innovation-9-female-led-businesses-backed

${ }^{4}$ https://www.gov.uk/government/publications/women-in-innovation-see-what-a-female-entrepreneurlooks-like 


\section{Strengthening the design and delivery of women's entrepreneurship support}

The successful delivery of women's entrepreneurship schemes often depends on several factors, including setting appropriate policy objectives and ensuring coherence with other gender policies. It is important to consult with women entrepreneurs during policy design and to build effective partnerships across public actors and with non-government organisations to ensure suitable delivery mechanisms are used. The impact of schemes should be tracked closely and fed back into how the support is designed and delivered. This chapter discusses these issues and presents five policy insight notes from Canada, Czech Republic, New Zealand, Northern Ireland (UK) and Sweden. Each note discusses some of the core questions in women's entrepreneurship policy, including whether dedicated policies and programmes are needed. Other notes assess approaches to implementing women's entrepreneurship policy strategies and the potential role of using the private sector to deliver public policy in this area. 


\section{Balancing mainstream and dedicated support}

One of the central questions policy makers face when designing entrepreneurship support for women is whether to provide better access to mainstream support for all entrepreneurs or to use a tailored and dedicated approach. There are three factors that should be considered when deciding on the approach:

- First, governments need to find out if women are aware of existing mainstream support offers and whether they are willing to use them. Although costlier, there is some evidence that women-only programmes are more effective at reaching women because women are more likely to be aware of them and more comfortable participating when they are women-only (OECD/EU, 2018; 2013).

- Second, selection and in-take mechanisms used by mainstream programmes can be genderbiased since they may not appropriately account for the different characteristics of businesses operated by women or the specific needs of women entrepreneurs. For example, women are often excluded from growth-oriented support programmes because women-owned businesses are often smaller than those operated by men and operate in low-growth sectors.

- Third, governments need to decide if women entrepreneurs need different content in support programmes since they often operate different types of businesses. It can be argued that business needs are gender-neutral but some researchers (e.g. Lougui and Nyström, 2014) argue that personal characteristics and the background of the entrepreneur are more important factors that influence the content of support programmes. Women, on average, tend to have different labour market experiences and different levels of social capital and, therefore, seek support to overcome different barriers.

In response to these issues, policies can pursue a combined approach of improving women's access to mainstream programmes, addressing the problems identified, and offering complementary dedicated services and programmes for women entrepreneurs.

\section{Defining objectives and targets}

Effective women's entrepreneurship policies and programmes tend to have clearly defined objectives that identify the desired outputs (i.e. what a policy produces) and outcomes (i.e. the conditions that policy seeks to alter) (OECD/EU, 2018; 2013). The process of defining objectives should include setting targets and identifying indicators that can be used to track progress against these targets and to assess the impacts made. A logic model can be used to help policy makers set targets and indicators that align with the desired policy outputs and outcomes. When defining indicators to track the impact of policy, it is important to avoid confusing outputs and outcomes since policy can only directly impact outputs. Indicators should be consistent over time and to the extent possible, use data that can be accessed without a long time lag.

The process of defining policy objectives and targets should include a consultation process that seeks inputs from a range of women's entrepreneurship stakeholders, including women's organisations, women's business associations, women entrepreneurs, educational institutions, as well as relevant ministries, departments, agencies, local authorities and non-governmental support organisations working with women. It can also be helpful to consult with experts in the field of inclusive entrepreneurship and to draw on the knowledge generated from past women's entrepreneurship policy experiences and those in other countries. Ultimately, the objectives should be consistent with, and linked to, broader labour market policy objectives for women. 


\section{Increasing programme outreach and accessibility}

Outreach is an important component of effective policy delivery since common reasons for low take-up of support among women entrepreneurs include a lack of awareness about the available support and an inappropriate programme interface.

Communication and outreach messages need to be clear and jargon-free, since many of the targeted women typically have little experience in entrepreneurship. It is most effective to deliver these messages through communication channels that will reach women, including dedicated networks and organisations. Outreach for many entrepreneurship programmes now occurs online, so it is important to ensure that the messages are disseminated through appropriate online platforms that are used by the different target groups of women.

It is also important to ensure that frontline staff on entrepreneurship programmes are sufficiently qualified to engage with women entrepreneurs. Entrepreneurship support agencies need to recruit people who have experience in working with different profiles of women entrepreneurs (e.g. part-time businesses, innovative STEM businesses) to ensure that they understand the range of challenges faced and that support is relevant. They can also provide gender awareness training to frontline staff, which often places a strong emphasis on communication skills. An additional consideration is that trust with scheme participants can be built more quickly when at least some members of frontline staff are women.

Policy makers can have an influence on this by placing conditions on the programmes and support organisations they fund. For example, funding conditions can require that a certain proportion of programme staff is from the target group, and/or that they receive training in working with the target group.

Another option for ensuring quality support delivery is certification of support providers. A small number of countries and regions offer certification programmes that ensure that support is of a high quality and relevant for women entrepreneurs. Such certifications can signal to potential clients that the support offered is relevant and that frontline staff is experienced in working with women entrepreneurs.

\section{Lessons from the policy cases}

The policy insight notes in this section tackle many of the broad questions in the field of women's entrepreneurship policy, notably whether women entrepreneurs should have dedicated public support or not. This core question is considered from local contexts in the notes from the Czech Republic, New Zealand and Northern Ireland, UK. Another pair of policy insight notes examine and discuss policy delivery. The note from Canada examines approaches to delivering on the relatively new Women Entrepreneurship Strategy, while the note from Sweden covers another important issue - is it more effective to deliver support directly through public institutions or through public sector delivery agents?

Collectively, the notes in this chapter point to the following takeaways to improve policy making to enhance women's entrepreneurship:

1. Strong framework conditions are a prerequisite for successful women's entrepreneurship. In New Zealand, for example, women's entrepreneurship is strong relative to many other countries despite a relatively under-developed women's entrepreneurship policy.

2. Coherence is needed between women's entrepreneurship policies and other policies. The importance of comprehensive (joined up) policy is illustrated in the case of the Czech Republic, where policies that encourage "re-familisation" have a negative influence on women's entrepreneurship because they encourage a return of women to full-time household responsibilities and an erosion of maternity allowances. 
3. Success in women's entrepreneurship policy can depend on having a strong delivery system. The policy insight note from Canada illustrates an area of fragility in programme eligibility criteria. While programmes are strong in specifying women-led enterprises they pay less attention to differences in the challenges faced by different types of women-owned businesses.

\section{References}

Lougui, M. and K. Nyström (2014), "What obstacles do entrepreneurs encounter?", Journal of Entrepreneurship and Public Policy, Vol. 3, No. 2, pp. 275 - 291.

OECD/EU (2018), "Policy Brief on Women's Entrepreneurship", OECD SME and Entrepreneurship

Papers, No. 8, OECD Publishing, Paris, https://doi.org/10.1787/dd2d79e7-en.

OECD/The European Commission (2013), The Missing Entrepreneurs: Policies for Inclusive

Entrepreneurship in Europe, OECD Publishing, Paris, https://doi.org/10.1787/9789264188167-en. 


\section{Canada}

By Barbara Orser, University of Ottawa

\section{Background}

In 2017 , women held a degree of ownership in $46.7 \%$ of employer SMEs, and majority ownership in $15.6 \%$ of SMEs (Statistics Canada, 2019). Women-owned businesses are significantly more prevalent among enterprises with fewer than 20 employees. Compared to men-owned start-ups, women-owned start-ups have a slightly lower survival rate and a significantly lower rate of growth of net income, labour productivity and investment in research and development (Statistics Canada, 2019). ${ }^{1}$

The need for policies and programming to support women-owned SMEs is well documented. A 2017 OECD review of SME and entrepreneurship policy in Canada identified challenges with respect to scaling-up, supporting high growth SMEs, and gaps in programmes for under-represented groups, including womenowned enterprises. In addition, at least 17 gender-based assessments of SME and entrepreneurship policies have been authored by academics, government and not-for-profits in Canada between 1986 and $2019 .^{2}$ Frequently cited recommendations include increased access to financial capital, and funding for networking, mentoring, training and advisory supports.

Support to SMEs and entrepreneurship are policy priorities in Canada (OECD, 2017). In 2018, the Government introduced Canada's first Women Entrepreneurship Strategy (WES) with an initial investment of CAD 2 billion. The WES seeks to double the number of women-owned businesses by 2025 and add CAD 150 billion to GDP. In 2020, investment in WES increased to CAD 5 billion (ISED, 2020). The WES strategy includes: funding to support programming for women-owned or led businesses and organisations that support them; capital targeted at women-owned and led businesses; improved access to federal contracting; and a women entrepreneurship knowledge hub. While the strategy reflects commitment to supporting women entrepreneurs, it could be strengthened by: (i) clarifying definitional criteria of "womenowned" businesses, (ii) bolstering federal contracting as a mechanism to support women-owned SMEs, and (iii) including demonstrated engagement of women entrepreneurs as proposal assessment criteria to mainstream small businesses and innovation support organisations.

\section{Policy issue: Operationalising the Women Entrepreneurship Strategy}

\section{Definitional criteria}

The WES strategy incorporates definitions for both women-led businesses (defined as one or more women in the leadership team) and women-owned businesses (where women are majority owners). These criteria are not without consequence. If entrepreneurial women are to become greater participants in the economy, it is crucial that women-owned businesses be prioritised with access to the full suite of WES federallyfunded programmes. In doing so, the federal government should adopt the criterion advanced by UN Women:

At least 51 percent unconditional ownership by one or more women; unconditional control by one or more women over the long-term decision-making and the day-to-day management and administration of the business operations; and independence from non-women-owned businesses.

More precise definitional criteria will avoid the facade of inclusion and diversity, and improve transparency of policy impacts. Certification of women-owned businesses is recommended. To support the ecosystem, 
the federal government could fund certification organisations and provide certification tax credits to foster transparent and impact-oriented investments.

The challenges facing women-led enterprises typically differ from those facing women-owned businesses. Within the WES strategy, the federal (2018) government has invested CAD 200 million in a fund promoted as: "the world's largest venture capital fund dedicated solely to investing in women-led technology companies across sectors." 3 The objective is to "Foster the creation of the next generation of millionaire Canadian women technology entrepreneurs." Eligibility includes "a woman founder, CEO, CTO, CFO or key C-suite position." As such, one woman promoted into the executive team qualifies, regardless of the number of men or the woman's degree of responsibility. Furthermore, in addition to a (broad) definition of women-led businesses, firm performance criteria for inclusion are onerous. Specified, as "[a] large, definable and defensible market opportunity; minimum viable product and initial market traction; early revenues and an ability to scale; first customer adoption or with revenues and accelerating sales growth quickly; a coachable team; raising a minimum of CAD 1 million in equity at the seed stage and up to CAD10 million at the growth stage." Very few women-owned businesses meet such criteria, criteria which appear to conflict with the spirit of The Government of Canada 2018 budget commitment: "...reform to federal innovation programs will include a universal goal to improve the participation of underrepresented groups, including women entrepreneurs, in the innovation economy" (p. 256).

The United States Office of Government Accountability (GAO, 2014) and Canadian Women Chamber of Commerce (Wilson, 2019) cite the need to define and validate "women-owned" businesses to avoid programme abuse, such as opportunistic placement of women in roles for the purpose of meeting programme eligibility criteria.

A rationale to employ women-led and minority women-owned SMEs is to include businesses that have diluted women's share of ownership because of provision of equity financing (Simpson, 2019). Potential equity dilution - which affects less than one in a thousand Canadian SMEs (Statistics Canada, 2017) could be included on an ad-hoc basis, for example through review by third-party certification agencies that review firm history to avoid programme abuse.

\section{Federal contracting as a mechanism to support women-owned businesses}

The Prime Minister of Canada has mandated the Minister responsible for Public Services and Procurement Canada, the federal procurement agency, to develop initiatives to increase the diversity of bidders on public contracts and the proportion of women-owned SME contractors from 10\% in 2017 to 15\% (Riding et al., 2018). Constructing inclusive procurement criteria and policies are not straightforward. Trade agreements can limit the ability of governments to favour under-represented SMEs. Procurement officers are typically assessed on the ability to adhere to established adjudication protocols and cost efficiencies, and not supplier diversity. While some reports have lauded the U.S. Women-owned Business Program (WOBP) or set-asides, defined as a percentage of spending allotted to under-represented small businesses, as good practice, robust evaluations - including that of the U.S. Office of Government Accountability (OGA, 2014) - have found little impact on bid frequency or success rates of women-owned businesses when firm size and sector are accounted for. Evaluation of the programme found weak oversight and a high percentage of self-certified contractors that did not meet criteria as women-owned businesses (OGA, 2014). ${ }^{4}$ The latter bears witness to the need for third-party certification. Currently, the government does not report on the gender ownership of SME suppliers. Data collection and reporting should include the percentage of women-owned businesses that are successful in winning government contracts, as well as the percentage of first-time bidders and bids submitted.

Provision of women-focused marketing, process and service innovation procurement programmes has also been recommended (Orser et al., 2018). These programmes will complement military and technology procurement programmes, and balance procurement programmes that implicitly prioritise men-dominated sectors (e.g. digital technology, Artificial Intelligence, protein, and manufacturing sectors supported by 
CAD 19 billion Innovation Super Cluster Investment). Support should also focus on assisting women business owners in navigating procurement "gateway" barriers, such as identifying contracting opportunities, bid or proposal writing and submission processes, and understanding pre-qualification documentation and processes (e.g. obtaining security clearances).

There is a need to weigh assessment criteria (scoring) to reward Tier 1 suppliers that sub-contract with under-represented groups of SMEs via sub-contracts. The government should clarify for industry stakeholders why and how policy options, such as set asides, conflict with trade agreements and other policy priorities. This will help inform stakeholders about viable policy options and address perceptions about an absence of substantive women-owned business procurement programming.

\section{Include demonstrated engagement of women-owned business in funding assessments}

Engagement of women or women-owned businesses is not a standard indicator for federal funding of small business and innovation support organisations. Bid or request for proposal (RFP) assessment criteria typically weigh economic outcomes indicators, such as job creation and increase in revenue. These performance indicators systemically exclude many women - who are more likely to operate smaller and newer businesses - to be self-employed without employees, and be engaged in social and services enterprises. Bidder assessment criteria for all federal-funded small business support organisations should include demonstrated inclusion of diverse women entrepreneurs, provision of gender and genderdisaggregated client data (e.g. take-up, retention, impacts), track record of hiring under-represented employees, and tangible evidence of gender-sensitive entrepreneurship education and training programmes and services. Illustrative content incorporates the types and models of businesses that women are more likely to operate, (e.g. non-profits, social enterprises and service-based firms), confidence building activities, financial literacy and setting business goals. Finally, staff, mentors and trainers should receive mandated training on equity, diversity and inclusion (EDI) - in the context of small business, entrepreneurship and innovation.

\section{Conclusions and recommendations}

Canadian federal funding and RFP evaluation criteria (grids or protocols) are designed to identify investments that tend to benefit men-owned or dominated firms and sectors. Inclusive programmes remain ad hoc, add-ons or pilots (Coleman et al., 2018). Robust analytics are needed to select and validate objectively the beneficiaries and conditions of policy interventions. The following recommendations could help address these limitations and support the achievement of the 2018/2020 WES objectives.

\section{Recommendations for Canada}

- Employ clear definitional criteria of women-owned businesses.

- Operationalise public procurement contracting as a mechanism for supporting women-owned businesses.

- Include demonstrated engagement of women entrepreneurs and inclusive programme impacts within requests for funding proposals from entrepreneurship support organisations, and not just economic indicators, such as job creation and revenue growth. 


\section{References}

Coleman, S., C. Henry, B. Orser, L. Foss, and F. Welter (2018), "Policy Support for Women Entrepreneurs' Access to Financial Capital: Evidence from Canada, Germany, Ireland, Norway, and the United States", Journal of Small Business Management, Vol. 57, No. 5, doi: 10.1111/jsbm.12473.

Government of Canada (2018), Women Entrepreneurs Strategy, Innovation, Science, Economic Development Canada, Ottawa, https://www.ic.gc.ca/eic/site/107.nsf/eng/home.

Innovation, Science and Economic Development Canada (2020), "Supporting Women Entrepreneurs in Canada during the COVID 19 Crisis", presentation by Etienne René Massie, Director General, Small Business Branch to OECD webinar, June 9, 2020.

OECD (2017), SME and Entrepreneurship Policy in Canada, OECD Studies on SMEs and Entrepreneurship, OECD Publishing, Paris, https://doi.org/10.1787/9789264273467-en.

Office of Government Accountability (OGA, 2014), Request to Congressional Requesters, Womenowned Small Business Program, Certifier Oversight and Additional Eligibility Controls are Needed. United States Government Accountability Office, Report to Congressional Requesters, Washington. https://www.gao.gov/assets/670/666431.pdf.

Orser, B., (2017), "Strategies to Redress Entrepreneurship Gender Gap in Canada", in Routledge Companion to Global Female Entrepreneurship, Henry, C., T. Nelson and K. Lewis (eds.), Routledge, London and New York, pp. 95-115.

Orser, B., C. Elliott and W. Cukier (2019), Strengthening Ecosystem Support for Women Entrepreneurs. Telfer School of Management, University of Ottawa in collaboration with The Diversity Institute, Ted Rogers School of Management, Ryerson University, http://sites.telfer.uottawa.ca/were/.

Orser, B., A. Riding and J. Weeks (2018), "The Efficacy of Gender-Based Federal Procurement Policies in the United States", Small Business Economics, doi: 10.1007/s11187-018-9997-4.

Riding, A., B. Orser and D. Li (2018), "Benchmarking Small and Medium Enterprises as Suppliers to the Government of Canada. Inclusion, Innovation and International Trade”, Telfer School of Management, University of Ottawa, Ottawa, http://sites.telfer.uottawa.ca/were/.

Simpson, M., (2019), “Innerspace Closes \$3.2 Million Seed Round Lead by BDC's Women in Tech Fund", Canadian Startup News, https://betakit.com/innerspace-closes-3-2-million-seed-round-led-bybdcs-women-in-tech-fund.

Statistics Canada (2019), "Women-owned businesses in Canada", April 3, 2019. Statistics Canada, Ottawa, https://www.statcan.gc.ca/eng/blog/cs/wob.

Statistics Canada (2017), "Survey of Financing and Growth of SMEs", https://www.ic.gc.ca/eic/site/061.nsf/eng/h 02774.html.

Wilson, N. (2019), "What's a 'women-led' company? We need a standard definition", Globe \& Mail, May 2 2019, https://www.theglobeandmail.com/business/commentary/article-whats-a-women-led-companywe-need-a-standard-definition/.

\section{Notes}

1 Women-owned businesses are significantly more prevalent among enterprises with fewer than 20 employees. Their share of medium- to high-growth SMEs (businesses with an annual sales or revenue growth rate above $10 \%$ over the past three years) increased from $16.5 \%$ in 2011 to $18.5 \%$ in 2017 . This compares with $18.3 \%$ in 2011, and to $20.8 \%$ in 2017 for men-owned SMEs. Between 2007 and 2017, the share of SMEs that requested external financing increased from $20.7 \%$ in 2007 to $40.6 \%$, compared with 
$22.9 \%$ in 2007 to $47.4 \%$ in 2017 for men-owned SMEs. Women-owned exporters increased from $5.9 \%$ in 2007 to $11.2 \%$ in 2017 (Statistics Canada, 2019).

2 See Orser (2017) for a summary of gender-based assessments of SME and entrepreneurship policies and programmes between 1989 and 2011.

\section{Access at:}

https://www.bdc.ca/en/bdc-capital/venture-capital/strategic-approach/pages/women-tech-fund.aspx.

4 Small Business Administration (SBA) eligibility examinations in 2012 and 2013 on a sample of businesses that received contracts under the WOSB Program found $42 \%$ and $43 \%$ of businesses were ineligible for WOSB Program contracts (OGA, 2014, p. 16). OGA (2014, p. 11) also reported on an absence of "procedures to conduct annual eligibility examinations: SBA had not "evaluated the results of the eligibility examinations in the context of how the actions of businesses, contracting agencies and thirdparty certifiers may have contributed to the high levels of incomplete and inaccurate documentations found in examinations..." (OGA, 2014, p. 11). 


\title{
Czech Republic
}

\author{
By Alena Křrižková, Institute of Sociology, Czech Academy of Sciences \\ Marie Pospišilová, Institute of Sociology, Czech Academy of Sciences
}

\section{Background}

The Czech Republic transitioned to a market economy in the 1990s. Business ownership was prohibited during state socialism from 1948 until $1989,{ }^{1}$ persisting only through the black market as a strategy for increasing insufficient income for households. This included various types of services such as repairs and retail sale of one's own products and cultivated crops, and bartering between households. This practice was tolerated by the regime in specific sectors (such as art). The transition led to both job losses and an increase in business opportunities, as state-owned enterprises were restructured and privatised. Research demonstrates the importance of small and medium-sized enterprises (SMEs) in the shift from socialism to capitalism in Central and Eastern Europe (Duh, Tominc and Rebernik, 2009). SMEs were particularly important for creating jobs, development of the market economy and for revival and development of an entrepreneurial tradition. Nevertheless, research on women-owned businesses and gender issues in entrepreneurship remains under-developed in transitional economies such as the Czech Republic.

While there was high employment of women under state socialism, the transition to capitalism led to calls for women's return to the home and reliance on male breadwinners, even though economic conditions did not produce wages sufficient for a solo breadwinner. These types of discourse were reinforced by prolonging parental leave and reducing state-funded childcare for children under the age of three. This policy framework encouraged work trajectories for women that were interrupted by extended leaves (Jurik et al., 2019) as well as discrimination against women as members of a secondary labour force (Kř́žková , Penner and Petersen, 2010), trends that, in turn, had a negative impact on the opportunities for women in the Czech labour market and on their choices, including entrepreneurship.

Despite mandatory employment and the proclaimed equality of men and women during state socialism, women experienced job segregation and inferior wages because policies failed to address the unequal division of housework, thus perpetuating the double burden on women and gender stereotypes (Hašková and Uhde, 2009). After 1990, demands for gender equality by Czech feminists arose, but were discredited ${ }^{2}$ by the legacy of communism (Hašková , 2005). The transition from state socialism to a market economy also triggered a trend towards more traditional gender roles. This trend included a call for women's return to the home, a reliance on male "breadwinners", and traditional attitudes towards the division of housework and caring responsibilities between partners that has persisted over the years. ${ }^{3}$ These attitudes have been supported by policies such as the prolongation of parental leave ${ }^{4}$ of up to three years per child and a sharp decrease in state-funding for childcare facilities. There is limited availability of flexible and part-time working arrangements, ${ }^{5}$ and discrimination against women with young children by employers is widespread (Formánková and Kř́žková, 2015). Within the context of restructuring the Czech economy, the call for women's return to the domestic sphere was also one of the strategies used to keep unemployment low (Hašková and Uhde, 2009). Despite this trend, which causes long interruptions in women's careers and their wage disadvantage and segregation at work, women's employment rates have stayed relatively high, ${ }^{6}$ and most women work full time.

In the Czech Republic, 31\% of entrepreneurs are women (CZSO, 2019a), and women's self-employment is increasing, particularly among women who have small children and those of pre-retirement age. ${ }^{7}$ However, self-employment is not always the first choice. Between 2013 and 2017, 27\% of Czech women who started businesses did so out of necessity (OECD, 2018). Qualitative research shows that one of the main needs claimed by women entrepreneurs is for flexible working conditions and work-life balance 
(Volejníčková et al., 2019), but flexible or part-time options and family-friendly working conditions are still rare within employment contracts (Formánková and Kř́źžková, 2015). Due to the restricted access of mothers of small children to secure employment contracts with family-friendly working conditions, ${ }^{8}$ women are often locked into unstable options in the labour market, such as short-term temporary contracts within the "gig economy" or self-employment. Research into legislation and taxation policy shows that the reality of women's self-employment is often precarious, marked with financial and social insecurity (Homfray, 2018; Kaiserová, 2018). Women are pushed into self-employment by a labour market that is biased against women and mothers and does not provide conditions for work-life balance (McCracken et al., 2015).

\section{Policy issue: Developing a women's entrepreneurship policy}

The main strategic documents addressing entrepreneurial support in the Czech Republic are produced by the Ministry of Industry and Trade (MIT) and The Office of the Government of the Czech Republic (OGCR). MIT strategies aim to foster competitiveness and economic performance, and to develop the innovative potential of SMEs (MIT, 2013). In its Action Plan for Support of Economic Growth and Employment (OGCR, 2017), the OGCR sets out the goal of increasing the attractiveness of the entrepreneurial sector. Neither gender nor the specific situation of women entrepreneurs are mentioned in these strategic economic documents. However, the Government Strategy for Equality of Women and Men in the Czech Republic for 2021-30 (OGCR, 2021) (hereafter the Strategy) discusses gendered aspects of entrepreneurship. The most notable issues identified include the risk of increasing the number of women working as entrepreneurs by default rather than by choice. One of the objectives of this Strategy is to provide systematic support to women entrepreneurs and to encourage greater monitoring of women's precarious entrepreneurship.

Research shows that self-employment is a "second choice" for under-represented groups of women such as mothers with small children, because women entrepreneurs with children are at a disadvantage compared to women employees with children. Women entrepreneurs' medical insurance benefits are significantly lower than those of women employees, and women entrepreneurs are not entitled to an allowance to care for a family member. Furthermore, access to maternity allowance is restricted, as women entrepreneurs are required to terminate their business in order to receive it ${ }^{9}$ (Homfray, 2018; Kaiserová, 2018). These conditions put many Czech women entrepreneurs, especially those with parental or other care responsibilities, into more vulnerable positions (Hašková and Dudová, 2017). The tax discount for a non-earning wife (the Czech version of joint taxation) is also a disincentive to women's entrepreneurship or employment. In the Czech Republic the breadwinner gains a spousal deduction if his/her spouse earns less than CZK 68000 per year. When combined with gender pay gaps and norms advocating women's responsibility for the home, this system encourages women to defer earning opportunities during and after paid parental leave or in other periods of intensive care. It also has a negative effect on women's income later in life (e.g. post-divorce, pensions). Further, the Czech Republic's joint taxation system permits the placement of married women in unofficial positions within family businesses, thereby posing a threat to their long-term wellbeing (e.g. entitlement of maternity benefit or lower pensions). These examples illustrate how gender stereotypes in the division of work within a household are embedded in the wider institutional context. Due to the gendered nature of this context and the expectations it creates, women are not only considered as an unreliable "secondary labour force" and discriminated against by employers (Kř́žková et al., 2009), but are also viewed as untrustworthy by financial institutions when applying for loans (McCracken et al., 2015).

In its Statement of the working group for women and economy (CWL, 2018) (hereafter the Statement), the Czech Women's Lobby $(\mathrm{CWL})^{10}$ stresses missing or inadequate support for women-owned firms to become viable and sustainable as a major problem. Both the Strategy and the Statement highlight the need for systematic and effective support for women entrepreneurs in the Czech Republic. In the last Programme term within the European Social Fund (ESF), support for women entrepreneurs was limited to training activities designed to encourage women to start ventures. However, the framework for the training programmes was not sufficient to ensure practical creation of new businesses or their long-term 
sustainability due to the lack of coordination between various support programmes managed by various ministries (some focused on training, some on consulting services), the short-term duration of such programmes, and the absence of special investment stimulus for micro financing.

Entrepreneurship has the potential to provide a solution to Czech women's restricted access to paid work, especially for women with caring responsibilities. However, the institutional context tends to reinforce gender inequalities, and neither the current nor prior levels of support for women entrepreneurs within ESF have been sufficient. Systematic, sustainability-focused and gender-sensitive policy support for women entrepreneurs is needed to address women's disadvantage in the labour market and the additional challenges women face when attempting to launch and develop businesses.

\section{Conclusions and recommendations}

The support provided to women entrepreneurs in the previous European Union programming period focused on pre-start-up training activities and offered limited support beyond the very initial stages of entrepreneurship. There is currently no specific policy support for women-led businesses in the Czech Republic in spite of the growing number of self-employed women. In the Czech cultural context, women entrepreneurs face the additional burden of an unequal division of work and homecare, combined with traditional gender expectations that are reflected in family and tax policies, and the lack of flexible, parttime and family-friendly jobs. The following recommendations are offered to increase effective support for Czech women entrepreneurs.

\section{Recommendations for the Czech Republic}

- Further develop gender-specific entrepreneurship policies that address the specific barriers faced by women entrepreneurs. Undertake systematic monitoring of the status of women entrepreneurs to ensure progress.

- Extend the focus of entrepreneurship support schemes for women entrepreneurs beyond business creation to also cover business sustainability and development, including greater efforts to improve access to finance and business counselling.

- Assess family, health, tax and entrepreneurship policies to ensure that measures do not disadvantage women entrepreneurs relative to male entrepreneurs or employees.

\section{References}

Czech Women's Lobby (2018), “Stanovisko pracovní skupiny ženy a ekonomika [Statement of the working group women and economy]", https://czlobby.cz/sites/default/files/projekty/stanovisko ps zeny a ekonomika 0.pdf (accessed 6 September 2019).

CZSO (Czech Statistical Office) (2019a), "Focus on Women and Men", https://www.czso.cz/csu/czso/zaostreno-na-zeny-a-muze-ffhk87f13g [accessed 28 June 2020].

CZSO (Czech Statistical Office) (2019b), "Míry zaměstnanosti, nezaměstnanosti a ekonomické aktivity leden 2020", https://www.czso.cz/csu/czso/cri/miry-zamestnanosti-nezamestnanosti-a-ekonomickeaktivity-leden-2020 (accessed 28 June 2020).

Dlouhá, M., N. Jurik and A. Křížková (2014), "Genderové inovace v malém pondnikání. Institucionální podmínky a dosahování genderové (ne)rovnosti u podnikatelských párů [Gender innovations in small 
entrepreneurship: Institutional conditions and management of gender (in) equality in copreneurial couples]", Gender, rovné přiležitosti, výzkum [Gender, Equal Opportunities, Research], Vol. 15, No. 2, pp. 87-100, https://doi.org/10.13060/12130028.2014.15.2.133.

Duh, M., P. Tomine and M. Rebernik (2009), "The Importance of Family Enterprises in Transition Economies", Eastern European Economics, Vol. 47, No. 6, pp. 22-42, https://doi.org/10.2753/EEE0012-8775470602.

European Commission (2017), "Country profiles - Czech Republic: Policies and progress towards investing in children," http://ec.europa.eu/social/main.jsp?catld=1248\&langld=en\&intPagEid=3637 (accessed 8 June 2020).

Eurostat (2019), "Temporary employees as percentage of the total number of employees", https://ec.europa.eu/eurostat/databrowser/view/tesem110/default/table?lang=en (accessed 28 June 2020).

Formánková, L. and A. Křižková (2015), "Flexibility trap - the effects of flexible working on the position of female professionals and managers within a corporate environment", Gender in Management: An International Journal, Vol. 30, No. 3, pp. 225-238, https://doi.org/10.1108/GM-03-2014-0027.

Hašková, H. and R. Dudová (2017), "Precarious work and care responsibilities in the economic crisis", European Journal of Industrial Relations, Vol. 23, No. 1, pp. 47-63, https://doi.org/10.1177/0959680116672279.

Hašková, H. and Z. Uhde (eds.) (2009), "Women and Social Citizenship in Czech Society: Continuity and Change", Institute of Sociology, Czech Academy of Sciences, Prague.

Hašková , H. (2005), "Czech Women's Civic Organising under the State Socialist Regime, Socioeconomic Transformation and the EU Accession Period", Sociologický časopis [Czech Sociological Review], Vol. 41, No. 6, pp. 1077-1110.

Homfray, Š. (2018), "V kvelbui na statku. Právní úprava a prekarizace samostatné výdělečné činnosti žen [In the shop and on the farm. Legal regulation and remarriage of women's self-employment]", Institute of Sociology, Czech Academy of Science, Prague, http://osvc.soc.cas.cz/sites/osvc.soc.cas.cz/files/v kvelbu i na statku def.pdf (accessed 6 September 2019).

ISSP (2012), ISSP 2012 - "Family and Changing Gender Roles IV" - ZA No. 5900, GESIS Data Archive, Cologne, https://cvvm.soc.cas.cz/cz/tiskove-zpravy/ostatni/vztahy-a-zivotni-postoje/5185-nazoryverejnosti-na-roli-muze-a-zeny-v-rodine (accessed 28 June 2020).

Jurik, N. C., Kř́žková, M. Pospišilová and G. Cavender (2019), "Blending, credit, context: Doing business, family and gender in Czech and US copreneurrships", International Small Business Journal, Vol. 37, No. 4, pp. 317-342, https://doi.org/10.1177/0266242618825260.

Kaiserová, R. (2018), "OSVČ Jakob prekérní práce z poled daní [Self-employment as a precarious work from the taxation perspective], Institute of Sociology, Czech Academy of Sciences, Prague, http://osvc.soc.cas.cz/sites/osvc.soc.cas.cz/files/osvc jako prekerni prace z pohledu dani def.pdf (accessed 6 September 2019).

Křižková, A., H. Maříková, R. Dudováand Z. Sloboda (2009), "The Conditions of Parenthood in Organisations: An International Comparison”, Sociologický časopis [Czech Sociological Review], Vol. 45, No. 3, pp. 519-547, https://doi.org/10.13060/00380288.2009.45.3.02.

Křižková, A., A. M. Penner and T. Petersen (2010), "The Legacy of Equality and the Weakness of Law: Within-job Gender Wage Inequality in the Czech Republic," European Sociological Review, Vol. 26, No.1, pp. 83-95, https://doi.org/10.1093/esr/jcp007.

Volejníčková, R.M., M. Švarcová, A. Křižková and L. Formánková (2019), "Podnikání matek malých dětí jako prekérní typ zaměstnání? Srovnání zkušeností podnikatelek s malými dětmi pưvodem z ČR a z Ukrajiny [ls Self-employment a Precarious Job for Mothers of Young Children? A Comparison of the 
Experience of Czech and Ukrainian Entrepreneurs with Small Children in the Czech Republic], Gender a Výzkum [Gender and Research], Vol. 20, No. 2, pp. 124-153, http://dx.doi.org/10.13060/25706578.2019.20.2.487.

McCracken, K., S. Marquez, C.C.Y. Kwong, U. Stephan and A. Castagnoli (2015), "Women's Entrepreneurship: closing the gender gap in access to financial and other services and in social entrepreneurship", European Parliament, Brussels, http://www.europarl.europa.eu/RegData/etudes/STUD/2015/519230/IPOL STU(2015)519230 EN.pdf (accessed 6 September 2019).

MIT (Ministry of Industry and Trade) (2013), "Koncepce podpory malých a středních podnikatelů na obdobi let 2014-2020 [Small and Medium Sized Enterprises Strategy 2014-2020]", www.mpo.cz/assets/dokumenty/47605/54370/599917/priloha001.pdf (accessed 6 September 2019).

OECD (2018), "Inclusive Entrepreneurship Policies, Country Assessment Notes: Czech Republic", https://www.oecd.org/cfe/smes/CZECH-REPUBLIC-IECountry-Note-2018.pdf (accessed 14 July 2020).

OGCR (Office of the Government of the Czech Republic) (2017), "Akční plán na podporu hospodářského růstu a zaměstnanosti - Aktualizace pro rok 2017 [Action Plan for the Support of Economic Growth and Employment - Update for 2017]", www.vlada.cz/assets/media-centrum/dulezitedokumenty/Akcni-plan-na-podporu-hospodarskeho-rustu-a-zamestnanosti-CR aktualizace-pro-rok2017.pdf (accessed 6 September 2019).

OGCR (Office of the Government of the Czech Republic) (2021), "Strategie rovnosti žen a mužủ na léta 2021 - 2030 [Gender equality strategy 2021-30]” https://www.vlada.cz/assets/ppov/rovne-prilezitostizen-a-muzu/Aktuality/Strategie rovnosti zen a muzu.pdf (accessed 10 April 2021).

PORC (Public Opinion Research Centre) (2020), "Public Opinion on the Role of Men and Women in Family - February 2020", The Public Opinion Research Centre, Prague, https://cvvm.soc.cas.cz/cz/tiskove-zpravy/ostatni/vztahy-a-zivotni-postoje/5185-nazory-verejnosti-naroli-muze-a-zeny-v-rodine (accessed 28 June 2020).

\section{Notes}

1 This was a gradual process between 1948 and 1953, when private businesses were closed, taken over by the state or transformed into state cooperatives. Since 1953 there were no private businesses.

2 With the transition to market capitalism, values such as equality and emancipation, and regulation such as quotas for participation of women in Parliament, were discredited as they were perceived as a communist legacy. This public attitude is still strong today, preventing promotion of feminist demands for gender equality in areas such as politics, decision making and family policy. For example, the return of women to paid work before their child is three years old is considered "bad mothering".

3 The Czech population holds gender-traditional attitudes on the division of gender roles in the family in high regard, and this has not changed significantly. In 1994, 51.5\% of the population agreed that "a man's job is to earn money and a woman's job is to look after home and family". In 2012, 47.3\% of the population still agree with this attitude (ISSP, 2012). More recently, doing common household repairs is regarded as men's work for $80 \%$ of the Czech population; for $63 \%$ of the population, cooking is regarded as women's work (PORC, 2020). 
${ }^{4}$ Women who had sickness insurance prior to birth are allocated 28 weeks of paid maternity leave per child. CR women or men are also eligible for parental leave; this includes paid parental allowances for up to 48 months, with job protection for up to 36 months (EC, 2017). Although parental leave is open to both parents, it is mainly taken by mothers (98.2\%) (CZSO, 2019b) as there is no direct motivation for fathers to avail of it.

${ }^{5}$ Only $10 \%$ of women work part-time (CZSO, 2019a).

${ }^{6}$ The employment rate for women (aged 15-64) was 68.2\% in 2019 (CZSO, 2019a).

7 In 1993, in the 20-44 years age category (the age of potentially parenting small children), there were 85000 women entrepreneurs; in 2010, there were 118000 , and in 2017, there were 127,000. In the age category 60+, there were 6000 women entrepreneurs in 1993, 20000 women in 2010 and 36000 women in 2018 (CZSO, 2019a).

8 In 2019, only $6.3 \%$ of all employees worked part-time (the EU 27 average was 11.9\%) (Eurostat, 2019). In combination with the lack of childcare for children under three years of age (quantity and unavailability of funding), women have limited opportunities to find employment at the Czech labour market (Dlouhá, Jurik and Kř́žková, 2014).

9 Self-employed mothers need to be contributing to sickness insurance for 180 days, and must stop their business activities when drawing maternity allowance. This means either closing down the business or delegating business ownership to someone else.

${ }^{10} \mathrm{CWL}$ is an umbrella organisation and a member of the European Women's Lobby (EWL); it defends the rights of women in the Czech Republic. CWL's mission is to take on the real problems women face and raise them at the political level. They also aim to improve the situation of women in society. 


\section{Background}

There is no explicit enterprise policy specifically designed to target women entrepreneurs in Aotearoa ${ }^{1}$ New Zealand. Further, there is also no overall discourse about the need for such policies. Reducing the gender wage and employment gaps and increasing women's representation in leadership and governance are among policy-focused areas that receive Government commitment and action. The "2018-20 Action Plan" for eliminating the gender pay gap in the Public Service, for example, has been established, and the Government has announced it will ensure that half of all directors on state sector boards and committees are women by 2021. However, there are no corresponding policy measures directly targeted at the different needs or challenges of women entrepreneurs relative to male counterparts.

New Zealand is characterised by a vibrant, progressive, hothouse environment for business creation. The country has a well-developed enterprise education system that not only exposes girls and young women to opportunities for increasing their knowledge base in respect to entrepreneurial behaviour, but enhances their perceptions of the feasibility of self-employment as a viable career path. There is also a welldeveloped infrastructure of hard support initiatives targeted at the nation's significant population of SME owners. This broad-based platform has served women's enterprise well. New Zealand, for example, was the top country for supporting women entrepreneurs according to the inaugural 2017 MasterCard Index of Women Entrepreneurs (MIWE), and retained this position in 2018. In 2019, New Zealand was ranked in second place behind the United States (MasterCard, 2019). The MIWE 2019 report tracks those factors that affect the gender divide in business start-up/ownership, including advancement outcomes, knowledge and financial access and support factors for entrepreneurial behaviour. New Zealand is strong in all of the thematic components, and is the only market to have ranked first in four sub-indicators: financial inclusion for women; gross enrolment rates for women in tertiary education; ease of doing business; and quality of governance. The MIWE (2019) report notes that about 3 in 10 business owners in New Zealand are women $\left(31.8 \%\right.$, ranking $\left.5^{\text {th }}\right)$. This ranking is higher than other wealthy innovation-led economies such as Singapore, Denmark, Spain, Canada and the United Kingdom.

\section{Policy issue: Is there a need for a gendered entrepreneurship policy?}

New Zealand's gender-neutral policy approach to enterprise calls into question whether or not a sound universal policy approach to improve the status of women and enable a vibrant enterprise culture gains more traction and satisfies the requirements of a specific country context. An exception, however, to New Zealand's generic approach is that of wāhine Māori (Māori women) in business who have some access to tailored support.

The Māori Women's Development Inc. (MWDI) was established in 1987 as an Indigenous institution, founded, managed and operated by Māori women. MWDI is geared toward the economic development of Māori Women and their whānau extended family, and as part of this mission provides basic support to nascent entrepreneurs at the planning and early growth stages. Government funding over several years has enabled MWDI activity, and currently, a partnership/sponsorship model maintains sustainability. MWDI extends microfinance as a last resort to women who have been unsuccessful in obtaining loans from mainstream banks, and offers capacity building opportunities to Māori women in business. A recently commissioned report provides insights on businesses owned by 6500 wāhine Māori aged 20 to 65 in 2017. It shows that $3 \%$ of Māori women own their own businesses, with the majority working in the agriculture, forestry and fishing; professional, scientific and technical services and construction ${ }^{2}$ sectors 
(Ministry for Women, 2019). The report also comments that, although business is a viable option, "there is limited specialist financial support or incentives available to wāhine Māori who want to establish a business" (Ministry for Women, 2019, p. 9). However, this report provides no new analysis on the gap between Māori women and men in business, although it briefly highlights significant enterprise gender gaps between Māori women and men, and between the Māori and the non-Māori and total country populations (MBIE, 2014).

There are also glaring disparities in women's entrepreneurial involvement in traditionally male dominated industries, namely STEM and the trade professions. Without intervention, the changes in social norms required for more girls and women to grow their skills and qualifications in these sectors will be slow. Despite growing acceptance of the need for more women in STEM areas, and the focus on this issue, there is anecdotal evidence that a lack of confidence impedes the entry of women into STEM-related industries. Nevertheless, evidence shows that affirmative action and selective targeting speeds up the process of growing the pipeline of women into male-dominated sectors. The building and construction industry is a case in point.

\section{Conclusions and recommendations}

New Zealand has experienced a degree of success in building women's entrepreneurship through a broadbased platform that supports business and innovation with no across-the-board women-targeted support initiatives. This perceived success may, however, be an illusion that is reinforced by limited statistical data analysis of gender gaps in entrepreneurship coupled with the lack of attention given to this issue in policyoriented documents and media. This is in stark contrast to other economic gender issues, such as the wage gap where there is concerted action to analyse and address the issue. As the OECD report on closing the gender gap emphasised, "[t]he paucity of reliable, up-to-date information makes monitoring trends in female entrepreneurship a daunting task. It is one of the main obstacles to better understanding female entrepreneurs' challenges and the effect on economic growth" (OECD, 2012, p.274). In New Zealand, the lack of timely availability and accessibility of data poses a significant challenge to understanding the needs of women in business. Improved information will bring into focus the nature and magnitude of the varied dimensions of the gender entrepreneurship gap, sparking discourse and highlighting any necessity for policy targeting. Based on the New Zealand experience, the following policy recommendations are offered.

\section{Recommendations for New Zealand}

- Consider the impact of the absence of a coherent gendered entrepreneurship policy agenda, and explore whether there are more advantageous ways of supporting women entrepreneurs beyond developing a dedicated women's enterprise policy.

- Undertake a fine-grained assessment of the needs of women entrepreneurs including measurement via national-level statistics.

- Address structural barriers to building the talent pipeline toward women's entrepreneurship, including high-growth entrepreneurship, by encouraging young girls into STEM and tradable activities; building young women's self-confidence and leadership skills via mentoring programmes; and developing vocational and tertiary entrepreneurship education programmes to support those already in place in primary and secondary schools.

\section{References}

BCITO (n.d.), "Women in construction: Diversity is good for business", 
https://bcito.org.nz/resources/women-in-construction/.

Davison, I. (2018), "Slow progress in getting New Zealand women into traditionally male fields", The New Herald, https://www.nzherald.co.nz/nz/news/article.cfm?c id=1\&objectid=12122944.

MasterCard (2019), "MasterCard Index of Women Entrepreneurs (MIWE) 2019", https://newsroom.mastercard.com/wp-content/uploads/2019/11/Mastercard-Index-of-WomenEntrepreneurs-2019.pdf.

Ministry of Business, Innovation and Employment (2014), "Māori in business: A report on Māori running their own business", https://www.mbie.govt.nz/assets/749791de0d/dec-2014-maori-in-business.pdf.

Ministry for Women (2019), Ngā wāhine kaipakihi: He tirohanga, Māori women in business: Insights, https://women.govt.nz/sites/public files/4218 MFW Maori\%20Women\%27s\%20Report final2\%20for \%20web 0.pdf

MWDI (2018), "MWDI 2016/2017 Annual Report: Building a sustainable platform”, https://mwdi.co.nz/wpcontent/uploads/2018/03/MWDI-Annual-Report-2016-2017.pdf.

OECD (2012), Closing the Gender Gap: Act Now, OECD Publishing, Paris, https://doi.org/10.1787/9789264179370-en.

\section{Notes}

${ }^{1}$ Aotearoa is the Māori name for New Zealand. Māori are the Indigenous people of Aotearoa.

2 The report points to explanations for why the result on construction may appear unlikely since difficulties in getting women into trade professions is well known: "First, the construction classification includes a number of sub-categories that tend to have a higher proportion of women in them (e.g., painting and decorating services and plastering and ceiling services). Second, a woman may be in business with a partner/spouse who is in one of the 'traditionally male' construction services" (p. 29). 


\section{Northern Ireland, United Kingdom}

By Joan Ballantine, Ulster University

Pauric McGowan, Ulster University

\section{Background}

Northern Ireland continues to lag behind the majority of the other regions of the United Kingdom (UK) in terms of entrepreneurship activity rates. The early-stage entrepreneurial activity (TEA) rate ${ }^{1}$ was $6.5 \%$ in 2018, relative to an overall TEA rate for the UK of $8.7 \%(9.1 \%$ in England, $6.3 \%$ in Wales and $6.7 \%$ in Scotland) (Department for the Economy, 2018). When the TEA rate is disaggregated by gender, women in Northern Ireland appear to be half as likely to be new entrepreneurs as men $(4.3 \%$ vs. $8.7 \%)$. Furthermore, there are significant differences in future start-up expectations in Northern Ireland by gender. Nearly $8 \%$ of men indicate that they intend to start a business in the next three years compared with only $2.3 \%$ of women (Hart et al., 2017).

\section{Policy issue: The absence of a dedicated women's entrepreneurship policy}

The above statistics point to a key policy issue for Northern Ireland, namely women are less likely than men to be entrepreneurs in the region. This finding is consistent with that previously reported for other regions and countries (OECD, 2017). A potential explanation is the absence of a dedicated policy on women's entrepreneurship. This is despite evidence, albeit limited, suggesting that women entrepreneurs face a number of specific challenges in Northern Ireland when compared to men counterparts: balancing work and family, non-supportive partners and low levels of confidence (McGowan et al., 2012). A lack of self-efficacy has also been identified as an additional challenge for women entrepreneurs in Northern Ireland, which negatively impacts on the development of their social capital (networking) (Hampton, 2018).

In another study of Northern Irish women owners of small to medium-sized accountancy practices (SMP), Hegarty et al. (2018) report that networking is gender-sensitive. Women participants indicated that confidence was a particular challenge in networking interactions, which were described as intimidating and dominated by men.

Despite lower rates of women's entrepreneurial activity and evidence that women entrepreneurs face a number of challenges, there is no dedicated policy on women's entrepreneurship in Northern Ireland. Women's entrepreneurship does not receive much visibility in key regional entrepreneurship policy documents. For example, the Economy 2030 consultation paper (Department for the Economy, 2017), which outlines proposals for a new Industrial Strategy for Northern Ireland, only briefly refers to women in the context of supporting a new region-wide women's entrepreneurship initiative - the "Yes You Can" programme. With financial support from the Department for the Economy, the "Yes You Can" programme is the result of collaboration between the Local Government sector (comprising eleven Super Councils), Invest Northern Ireland and the Women in Business Network. Encompassing a series of events (e.g. training sessions, networking meetings, bootcamps) at different stages of a woman's entrepreneurial journey, including access to women's networks, the programme has been specifically tailored to support women entrepreneurs in Northern Ireland. The Draft Programme for Government Framework 2016-21 (Northern Ireland Executive, 2016) is also relatively silent on the issue of women's entrepreneurship, while the Department for the Economy's Entrepreneurship in Northern Ireland context paper (2018) briefly suggests that a key attribute of entrepreneurship on which Northern Ireland can build is the growing global "culture of female entrepreneurship" (p.8). Interestingly, the context paper does not elaborate on how Northern Ireland might build on this attribute to bring about gains for women entrepreneurs in the region. 


\section{Conclusions and recommendations}

The lack of attention toward women's entrepreneurship in key regional policy documents has been criticised by the Equality Commission for Northern Ireland (ECNI) (2017). While welcoming the commitment of the Department for Economy to the "Yes You Can" programme, the ECNI has highlighted the lack of reference to the promotion of equality of opportunity for women, particularly in the Economy 2030 strategy. Reflecting this gap, the ECNI recommend the "inclusion of additional stronger high-level commitments, underpinned by robust actions, specifically relating to the promotion of equality [for females]" (p.5). Similarly, the ECNI (2017) is critical of the Draft Programme for Government Framework 2016-21, recommending the need for equality of opportunity (particularly for women) as central to all public policy development and implementation. Based on their analysis of both the Economy 2030 strategy and the Draft Programme for Government Framework 2016-21, the ECNI (2017) recommend the adoption of a gender-sensitive approach to identifying key actions and "additional scope for the promotion of equality to be embedded and mainstreamed" (p.1).

\section{Recommendations for Northern Ireland, UK}

- Articulate a regional women's entrepreneurship policy strategy involving a package of actions to address barriers faced by women entrepreneurs.

- Conduct robust equality assessment (i.e. screening and equality impact assessment) on all entrepreneurship support programmes to ensure equality of opportunity for women.

- Further develop the evidence base on specific issues faced by women entrepreneurs, including collection of gender-disaggregated data on participants in public entrepreneurship support programmes.

\section{References}

Department for the Economy (2018), "Entrepreneurship in Northern Ireland Context Paper", www.economy-ni.gov.uk/sites/default/files/publications/economy/Entrepreneurship-in-NorthernIreland-context-paper.pdf.

Department for the Economy (2017), "Economy 2030: A consultation on an Industrial Strategy in Northern Ireland", https://www.economy-ni.gov.uk/sites/default/files/consultations/economy/industrialstrategy-ni-consultation-document.pdf.

Equality Commission for Northern Ireland (2017), "Response to the Department for the Economy's consultation on Economy 2030: An Industrial Strategy for Northern Ireland", www.equalityni.org/ECNI/media/ECNI/Consultation\%20Responses/2017/DeptEconDraftIndustrialStrategy.pdf.

Hampton, A. (2018), "The role of self-efficacy in developing women's social capital for entrepreneurial formation and growth in Northern Ireland", in Ballantine, J. and P. McGowan (eds.) Women into Business in Northern Ireland: Opportunities and Challenges, p. 9-24, www.businessfirstonline.co.uk/wp-content/uploads/2018/06/REPORT-Women-into-Business-inNorthern-Ireland-Final.pdf.

Hart, M., K. Bonner, J. Levie and L. Henry (2017), "GEM UK: Northern Ireland Report 2017", www.economy-ni.gov.uk/publications/global-entrepreneurship-monitor-gem-uk-ni-report-2017.

Hegarty, C., C. Barrett and C. Scott McAteer (2018), "Women as networkers: a study of the practices of women owners of small to medium accountancy practices (SMPs) in Northern Ireland", in Ballantine, J. and P. McGowan (eds.) Women into Business in Northern Ireland: Opportunities and Challenges, p. 25-39, www.businessfirstonline.co.uk/wp-content/uploads/2018/06/REPORT-Women-into- 
Business-in-Northern-Ireland-Final.pdf.

McGowan, P., C. L. Redeker, S. Y. Cooper and K. Greenan (2012), "Female entrepreneurship and the management of business and domestic roles: Motivations, expectations and realities", Entrepreneurship \& Regional Development, Vol. 24, No. 1-2, pp. 53-72.

Northern Ireland Executive (2016), "Draft Programme for Government Framework 2016-21", www.northernireland.gov.uk/sites/default/files/consultations/newnigov/draft-pfg-framework-201621.pdf.

OECD (2017), The Pursuit of Gender Equality: An Uphill Battle, OECD Publishing, Paris, https://doi.org/10.1787/9789264281318-en.

\section{Note}

${ }^{1}$ The total early-stage entrepreneurship rate estimates the proportion of the population that is involved in setting up a new business or managing one that is less than 42 months old. 


\section{Sweden}

By Helene Ahl, Jönköping University

This policy insight note was drafted by an independent researcher and does not necessarily reflect the official views of the OECD or the Government of Sweden.

\section{Background}

Sweden has benefitted from dedicated policy support for entrepreneurship and business development since the establishment of the Regional Development Funds in the late 1970s. The initial policy objective was to stimulate business development in locations where industrial restructuring resulted in job losses. In 1994, the Regional Development Funds were replaced by ALMI Företagspartner AB, a fully state-owned corporation with a mandate to provide business counselling and start-up loans. In addition, Local Enterprise Agencies were established in 1985 to stimulate business creation (Ahl and Nelson, 2015). In 2009, approximately SEK 42.5 billion was made available in both direct and indirect business development support, including tax relief and loan programmes (Growth Analysis, 2011). However, ostensibly genderneutral rules and regulations for accessing support often placed women entrepreneurs at a disadvantage. There are differences in terms of industry, size and markets between businesses owned by women versus men. Women are, for example, more likely to have a small business with a local market, and often in a service-based industry (Tillväxtverket, 2012), whilst many forms of support are tailored to manufacturing firms or the export industry. An evaluation in 2007 showed that a disproportionate share of support monies went to businesses owned by men (Nutek, 2007).

The first programme dedicated specifically to supporting women's entrepreneurship involved women business advisors in economically disadvantaged areas. The programme was established in 1992 and discontinued in 2002, when it was largely integrated into ALMI's mainstream advisory system. A study of this programme found that tailored advice and counselling for women entrepreneurs was "side ordered" and viewed as less legitimate by the business development support staff (Nilsson, 1997). In addition, the Regional Resource Centres for women that were established in 1994 were discontinued in 1999, after which many of the centres continued as local or regional independent non-profit organisations. By 2019, the majority of these local associations were discontinued.

In 2007, the liberal/conservative government coalition initiated a new initiative (Promoting Women's Entrepreneurship), which continued until 2015. The programme was well-funded and focused solely on promoting economic growth, i.e. more women-owned businesses and more new jobs; gender equality was the means rather than the end (Ahl et al., 2016). The programme provided: specialised business training services and development projects for women; trained support staff in gender awareness; enterprise activities for prospective women entrepreneurs at universities; communication about networks for women business owners, and an unpaid ambassador initiative whereby women entrepreneurs were asked to volunteer as role models inspiring schoolgirls to pursue entrepreneurship as a career. An annual "Beautiful Business Award" competition was also launched (Berglund et al., 2018). A programme evaluation on 2397 participating firms found a positive effect on growth and short term employment, but not on longterm employment or survival (Tillväxtverket, 2018).

\section{Policy issue: Privatisation of public welfare delivery has not helped women entrepreneurs}

In 2015, all programmes for women entrepreneurs were discontinued. The new National Strategy for Business Promotion on Equal Terms (Open Up) focused on diversity, not for the sake of diversity itself, but for the overall goal of economic growth. The strategy explicitly states that Sweden needs more 
entrepreneurs who are women, ethnic minorities, young and seniors to secure economic growth; the point of achieving equal access to business ownership is thus economic growth; equality is not an aim by itself (SAERG, 2015, pp. 44-45). However, targeted funds were not dedicated to any of these groups - it was essentially a gender mainstreaming strategy.

In parallel to these developments, Sweden has undergone the marketization and privatisation of its public sector. Many public sector operations have been opened for private sector competition through the use of public procurement and voucher systems. While the services are still funded by public funds, they are free or almost free to the consumer. This has created quasi-markets in the school and health-care sectors, with privately-owned but publicly funded businesses. These are sectors dominated by women in employment terms. The government propositions preceding many of the women's entrepreneurship programmes that operated over the period 1992-2015 included arguments that women who used to be employed by the public sector should avail themselves of these new business opportunities and thus create jobs for themselves and others (Ahl et al., 2016). Marketization of the public sector and support for women's entrepreneurship thus worked in tandem.

The outcomes of the policies described above are sobering. The increase in women-owned businesses did not change gendered segregation by industry, nor did it improve women's financial situation. The share of women-owned businesses increased from 32\% in 2009 to $38 \%$ in 2016, but the gendered employment and business landscape remained, with women concentrated in occupations such as social work, personal and cultural services, and education (SCB, 2018). The privatisation efforts resulted in more women-owned businesses, but even more men-owned businesses. In sectors such as hospital care, secondary schools and nursing homes the result was the creation of a small number of large new businesses that succeeded by leveraging their economies of scale (Sköld, 2015). A recent study on Swedish registered data found that the median disposable income of women entrepreneurs in Sweden was lower than that of women employees, who in turn made less money than men (Sköld et al., 2018). Remunerations from the welfare system (such as sick leave pay, parental leave pay, or unemployment insurance) follow suit, since these are tied to taxable employment income. Thus, replacing a welfare system delivered by the public sector with private business ownership did not improve women's financial situation.

\section{Conclusions and recommendations}

Neither privatisation nor marketization, nor programmes tailored for women's entrepreneurship have managed to challenge the gendered business landscape. Women's businesses are still largely concentrated in feminine gendered sectors with low earning potential, so having a regular job may actually pay better than owning a business. For future policy to benefit women entrepreneurs, and be an instrument for increased gender equality in entrepreneurship, there is a need not only to continue a gender mainstreaming policy, but also to consider the gendered division of occupations, the gendered differences in pay or profitability between different sectors, and how privatisations of public sector welfare responsibilities impact women. 


\section{Recommendations for Sweden}

- Mainstream policy support for women's entrepreneurship, i.e. integrate a gender perspective into all steps of policies and programmes affecting business development.

- Reduce bias against women entrepreneurs by changing the eligibility criteria for general business support in terms of, for example, supported markets or industries. Current criteria favour industries and markets where most business owners are men.

- Change the criteria for selecting enterprises in public procurement processes. Current criteria disfavour small-scale businesses typically owned by women.

\section{References}

Ahl, H., K. Berglund, K. Pettersson and M. Tillmar (2016), "From feminism to FemInc.ism: On the uneasy relationship between feminism, entrepreneurship and the Nordic welfare state," International Entrepreneurship and Management Journal, Vol. 12, No. 2, pp. 369-392.

Ahl, H. and T. Nelson (2015), "How policy positions women entrepreneurs: A comparative analysis of state discourse in Sweden and the United States," Journal of Business Venturing, Vol. 30, No. 2, pp. 273-291.

Berglund, K., H. Ahl, K. Pettersson and M. Tillmar (2018), "Women's entrepreneurship, neoliberalism and economic justice in the postfeminist era: A discourse analysis of policy change in Sweden," Gender, Work \& Organization, doi.org/10.1111/gwao.12269.

Growth Analysis (2011), "Entrepreneurship and SME policies across Europe: the Swedish concluding report”, Swedish Agency for Growth Policy Analysis, Östersund.

Nilsson, P. (1997), "Business counselling services directed towards female entrepreneurs - some legitimacy dilemmas”, Entrepreneurship and Regional Development, Vol. 9, No. 3, pp. 239-258.

NUTEK 2007. "Utfall och styrning av statliga insatser för kapitalförsörjning ur ett könsperspektiv" [Outcome and governance of state support for capital provision from a gender perspective]. Stockholm: Nutek.

SAERG (2015), "Open up! National Strategy for Business Promotion on Equal Terms 2015-2020", Info 0606, Tillväxtverket, Stockholm.

SCB (2018), "Women and men in Sweden. Facts and figures 2018", Statistics Sweden, Örebro.

Sköld, B. (2015), Vad hände? Kvinnors företagande och de strukturella villkoren - en studie i spåren av den offentliga sektorns omvandling, Linköping University, Linköping.

Sköld, B., M. Tillmar, H. Ahl, K. Berglund and K. Pettersson (2018), Kvinnors företagande $i$ landsbygdskommuner med fokus på Småland och Öland: En kvantitativ kartläggning inom ramen för forskningsprojektet "Kvinnors företagande för en levande landsbygd", Linköping University, Linköping.

Tillväxtanalys (2018). "Främja kvinnors företagande - resultat av affärsutvecklings- och innovationsinsatser". PM 2018:21. Swedish Agency for Growth Policy Analysis, Östersund.

Tillväxtverket, (2012), "Women' and men's enterprise in Sweden - The Situation and Conditions of Enterprises 2012", Tillväxtverket, Stockholm. 


\section{Building entrepreneurship skills for women}

Entrepreneurship skills can be acquired by individuals in various ways, including through business experience, entrepreneurship education and training, receipt of business advice, and interactions with other entrepreneurs and business professionals. Having entrepreneurship skills does not guarantee business success, but can increase the chances of business survival and growth. Women are less likely to report having entrepreneurship skills than men, and this gap is often due to differences in education and experience. This chapter explores the potential for public policy to support the acquisition of entrepreneurship skills by women. The discussion is illustrated by three policy insight notes from Denmark, Poland, and Tanzania. The notes illustrate a range of challenges for policy makers as well as success factors for implementing effective policy measures. 


\section{The need for gender-based entrepreneurship education and training}

Access to entrepreneurship education and training is an important success factor for entrepreneurship. Much of the work can be laid down in formal education systems, but timely follow-up support is also needed after formal education. Higher education in particular has been shown to increase women's likelihood of becoming both entrepreneurs and employers (Okten, 2015). Yet, despite their increasingly higher levels of educational attainment, women remain under-represented in entrepreneurship, especially within STEMbased, high-tech and high-growth enterprises. In part, this is due to gender differences in entrepreneurship education and skills (Cheraghi and Schøtt, 2015).

\section{The role of public policy}

Public policy has many levers to address barriers in entrepreneurship skills, including entrepreneurship education, training, coaching and mentoring, and business advice (OECD/EU, 2019; 2018). Entrepreneurship training programmes in particular are specifically designed to boost an entrepreneur's know-how about starting and operating a business. The content tends to focus on business and financial planning, identifying markets and customers, financial and risk management, managing human resources and other areas.

Coaching and mentoring relationships among professional business advisors or experienced entrepreneurs and novice entrepreneurs offer many benefits for building the skills of new and existing entrepreneurs. While some people use the terms coaching and mentoring synonymously, coaching refers to short-term relationships that seek to address a specific challenge faced by business owners, while mentoring is often a long-term relationship that has a greater focus on individual development. The most important success factor for entrepreneurship coaching and mentoring is the quality of the match between the inexperienced entrepreneur (i.e. coachee/mentee) and the experienced entrepreneur (i.e. coach/mentor). Most coaching and mentoring programmes for women entrepreneurs in OECD countries use interviews to ensure that the needs of the coachee/mentee are aligned with the experience of the coach/mentor.

The provision of business advice - often through women's enterprise/entrepreneurship centres (WECs) has become a relatively common practice in OECD countries. This type of business support offers both general and tailored training geared to the specific needs of individual entrepreneurs to help them overcome the challenges of start-up and obstacles to sustaining and growing their businesses. WECs also often assist women entrepreneurs in securing start-up financing and other business development services.

As noted in Chapter 4, a core question for governments is whether to facilitate the acquisition of entrepreneurship skills by women through better access to mainstream programmes for the whole population or through dedicated and tailored programmes for women. Tailored programmes have been shown to be more effective than generic, mainstream measures because they address specific needs but they are typically costlier to develop and deliver (OECD/EU, 2013).

\section{Lessons from the policy cases}

The three policy insight notes in this section highlight not only the benefits of offering gender-focused entrepreneurship education and training to facilitate women's entrepreneurship, but a need to expand such provisions. The notes draw attention to problems with the effectiveness of many existing entrepreneurship skills policies and programmes for women, often due to ill-informed design, uncoordinated delivery or duplicative programming. They also point to the issue of general education choices by women that do not match well with the skills base needed to pursue entrepreneurial careers. 
Most of the policies and programmes discussed in these notes are generic and not contextualised to particular geographical settings or sectors. This is shown to be problematic in countries where women face additional barriers due to prevailing cultural and societal norms and resulting expectations. Policies and programmes that fail to acknowledge these differences or treat women entrepreneurs as a homogenous group, are less effective. These points are illustrated among small rural businesses that are unable to access appropriate supports, and among women entrepreneurs operating in the informal economy. The reflections provide evidence of policies without programmes. In some countries such as Tanzania, womenfocused entrepreneurship policies in relation to education and skills have been designed by government, but corresponding policy measures have not yet been implemented.

This section also highlights examples of women-focused initiatives that appear to be having a positive impact. For example, Poland's Foundation for Female Entrepreneurship is a comprehensive support programme providing entrepreneurship skills and mentoring targeted at young women at the business start-up phase.

Collectively, the policy insight notes in this chapter point to the following key policy takeaways:

1. Entrepreneurship education needs to start early and cover all disciplines. Starting early, for example in primary school, is important so that young girls understand that entrepreneurship is a viable career option and that young girls gain confidence, skills and experience to identify and exploit entrepreneurial opportunities. Entrepreneurship education is important across all discipline areas, but particularly in those areas dominated by women, such as the Humanities, that may not typically lend themselves to entrepreneurial activity.

2. Entrepreneurship education and training programmes must respond to context and variety among women entrepreneurs. Entrepreneurship skills development programmes must respond to the specific skills needs of different types of women entrepreneurs and the different types of sectors in which they operate. The policy insight notes in this section show that "one size does not fit all."

\section{References}

Cheraghi, M. and T. Schøtt (2015), "Education and training benefiting a career as entrepreneur", International Journal of Gender and Entrepreneurship, Vol. 7, No. 3, pp. 321-343, http://dx.doi.org/10.1108/lJGE-03-2013-0027.

Foss, L. (2017), "Revisiting Research on Gender in Entrepreneurial Networks", in C. Henry, T. Nelson and K.V. Lewis (eds.), The Routledge Companion to Global Female Entrepreneurship, Abington: Routledge, pp. 214-232.

Hanson, S. and M. Blake (2009), "Gender and Entrepreneurial Networks", Regional Studies, Vol. 43, No. 1, pp. 135-49.

Henry, C., H. Lawton Smith, V. Meschitti, L. Foss and P. McGowan (2020), "Networking, gender and academia: An ecosystems approach" in H. Lawton Smith, C. Henry, H. Etzkowitz and A. Poulovassilis (eds.), Gender, Science and Innovation: New Perspectives, Cheltenham: Edward Elgar.

Minniti, M. (2017). "Female Entrepreneurship, Role Models and Network Externalities in Middle-Income Countries", in C. Henry, T. Nelson and K.V. Lewis (eds.), The Routledge Companion to Global Female Entrepreneurship, London: Routledge, pp. 197-213.

OECD/European Union (2019), The Missing Entrepreneurs 2019: Policies for Inclusive Entrepreneurship, OECD Publishing, Paris, https://doi.org/10.1787/3ed84801-en.

OECD/EU (2018), "Policy Brief on Women's Entrepreneurship", OECD SME and Entrepreneurship Papers, No. 8, OECD Publishing, Paris, https://doi.org/10.1787/dd2d79e7-en.

OECD/The European Commission (2013), The Missing Entrepreneurs: Policies for Inclusive Entrepreneurship in Europe, OECD Publishing, Paris, https://doi.org/10.1787/9789264188167-en. 
Ökten Hasker, C. (2015), "Female entrepreneurship in Turkey: patterns, characteristics, and trends", Washington, D.C.: World Bank Group, http://documents.worldbank.org/curated/en/952081479279116824/Female-entrepreneurship-inTurkey-patterns-characteristics-and-trends. 


\section{Denmark}

By Helle Neergaard, Aarhus University

\section{Background}

Denmark ranks $14^{\text {th }}$ among 153 countries with respect to gender equity in economic participation and opportunity, educational attainment, health and survival, and political empowerment, according to the Global Gender Gap Report (Zahidi et al., 2020). While this is encouraging, Denmark lags behind other Nordic countries: Iceland, Norway, Finland and Sweden rank respectively $1^{\text {st }}, 2^{\text {nd }}, 3^{\text {rd }}$ and $4^{\text {th }}$. With regard to equality in economic participation and opportunity in comparison with other Nordic countries, the picture is bleaker (eports.weforum.org). Denmark is characterised by deeply-rooted gender imbalances that have not changed in the last decade (Politiken, 2018). Since 2008, Denmark has taken a gender-neutral approach to entrepreneurship policy. This implies that entrepreneurship policies do not differentiate the support needs of women and men, as policy makers assume the needs of business ownership to be identical (Petterson, 2012). Danish women entrepreneurs are invisible within an increasingly gender imbalanced society.

Although women-owned businesses constitute one of the fastest growing entrepreneurial populations in the world (Brush, 2006), Eurostat data (2016) indicate that Denmark's share of self-employment within the EU is among the lowest of the ranked economies. With regard to new business ownership, for example, Denmark ranks third last (GEM 2019/2020). The dearth of Danish women entrepreneurs has attracted attention from multiple actors, such as the non-governmental Danish Entrepreneurship Association, whose director has stated, "[t]he situation is unsustainable. Our country lacks entrepreneurs, especially women to create and develop a rich society" (2018: p. 1.3).

To date, there has been little policy response to address gender differences in the level of entrepreneurial activity. The most pertinent challenges relevant to Danish women entrepreneurs include, among others: lack of entrepreneurship education for women; vulnerability of women in self-employment; dual entrepreneur and caregiver roles, and political emphasis on sectors and types of growth in which women are under-represented (Neergaard and Weber, 2018; Grünfeld et al., 2020). These four key policy issues are considered below.

\section{Policy issues: Education, self-employment, dual roles and political priorities}

\section{Education}

Although Danish women have higher educational attainments than men (OECD, 2019), most complete degrees in the Humanities such as Arts, Journalism, Education, Health and Welfare, and Other Services. These academic disciplines do not typically provide the skills and competences needed to launch or manage a small business (Grünfeld et al., 2020). Indeed, 32\% of Danish women perceive that they lack the competences needed for business start-up (Danish Chamber of Commerce, 2020). Moreover, significantly more men than women receive entrepreneurship education and establish businesses during and after graduation (European Commission, 2014). Danish women entrepreneurs, therefore, face a double bind: they lack the education and experience to start a business and have a tendency to start businesses in the "wrong" sectors (see the following section on self-employment). Lack of knowledge for starting a business remains a major obstacle.

\section{Self-employment}

Eighty percent of women entrepreneurs in Europe are solo-entrepreneurs or own-account workers (European Commission, 2014). In Denmark, the corresponding number is $87 \%$ while another $7 \%$ have one 
employee only. Women solo entrepreneurs constitute the largest cohort in the Education, Human Health and Social Work, Other Services, and the Arts, Entertainment and Recreation sectors (Grünfeld et al., 2020). Public sector entities compete in most of these sectors, and hence, are able to finance and take risks that solo entrepreneurs cannot. It is also difficult for women to start businesses in sectors in which they are not educated (Grünfeld et al., 2020$)$. The majority of women solo entrepreneurs $(79 \%)$ are liberal professionals and freelancers, and fall into the "precariat class" of employment. The precariat class includes individuals in temporary, short-term employment contracts or with fluctuating income, who accordingly have little predictability or security in their jobs (McKay et al., 2012). Self-employed workers are generally perceived to be "vulnerable workers" (Cho et al., 2016) due to workplace isolation, limited social safety nets, and operating under conditions of uncertainty (de Mol et al., 2018); they also have little job security, long working hours (more than the legislated 37-hour work week for employees), lack pensions and savings, and have limited entitlement to state benefits and private health-insurance coverage (Johnson, 2015). Many women also describe themselves as being at greater risk than employees due to the status of their work (EU-OSHA, 2010). While this is true for all workers, given that $70 \%$ to $80 \%$ of women entrepreneurs are solo/own-account workers, these issues are particularly pertinent. Danish women entrepreneurs also have a higher mortality rate compared to men entrepreneurs, while men entrepreneurs live $10 \%$ longer than the general male population (Andersen et al., 2009). The vulnerability of self-employment as an entrepreneurial career constitutes a significant barrier for women.

\section{Dual entrepreneur and caregiver roles}

In Denmark, women continue to assume the primary role of caregiver. Many enter business ownership to achieve flexibility and work/life balance. For some women, entrepreneurship is viewed as a way to conciliate family and professional demands. Danish legislation, however, makes it difficult to maintain a business while on maternity leave (Neergaard and Thrane, 2011). Indeed, maternity benefits are based on a percentage of earnings in the previous year, and earnings of nascent or new firms are generally low. Women are permitted to work a few hours per day while on maternity leave. Parental responsibilities and inadequate maternity leave policies result in discontinuance of many women-owned businesses (Neergaard and Thrane, 2011).

\section{Political priorities}

Danish entrepreneurship policies prioritise rapid-growth enterprises, as evidenced in the types of support programmes offered by government (e.g. by the Innovation Foundation). Yet, across most economies and compared to men, women typically grow their businesses at a slower rate (Grünfeld et al., 2020). Many women also prefer to grow their businesses through collaboration with other firms, rather than through hiring. Incremental growth in turnover and job creation are then spread over many businesses, a practice that is not adequately captured by traditional government measures of economic contribution and firm growth. Furthermore, traditional financial institutions, such as banks, rarely take a long-term perspective or fully understand the liberal professions. This affects their ability to advise and support entrepreneurs in these professions and can result in declined financing (Constantinidis et al., 2006; Leitch et al., 2018). Capitalisation of firms can require entrepreneurs to relinquish a portion of the ownership. Further, many women prefer steady and measured growth (profit over scaling) and self-financing. Research also shows that women use crowdfunding more successfully than men, both in raising money and in reaching their finance targets (Abouzahr et al., 2018). Crowdfunding may be a preferred choice because it does not require dilution of firm ownership or collateral (Chandramouli, 2018). Therefore, it is important to identify

gender-sensitive metrics, and to educate financial advisors and providers of capital on women entrepreneurs' preferences and needs. 


\section{Conclusions and recommendations}

Since 2014, Denmark has had no policies or small business initiatives targeted explicitly at women entrepreneurs (Petersson et al., 2017), and no strategy for increasing support to women entrepreneurs within mainstream entrepreneurship initiatives. Yet, research suggests that dedicated women's programmes have a greater impact in incentivising women's entrepreneurship than mainstream programmes (OECD/EU, 2018). There remains a need for increased awareness of the different conditions faced by entrepreneurial men and women, and differences in management practices to inform the development of gender-sensitive entrepreneurship policies.

Traditional government metrics used to gauge economic contribution are insufficient for enhanced understanding of the ecosystem mechanisms that result in performance variations among entrepreneurial men and women. Measuring growth in terms of turnover and employees, for example, portrays womenowned enterprises as "less" when many women choose forms or strategies of growth that are not reflected in these measures. Understanding the contributions and decisions of women entrepreneurs is essential for the development of policies to strengthen the entrepreneurial ecosystem, fixing the system rather than "fixing" women to match the expectations of men. This will require consultation with women entrepreneurs to gain an in-depth understanding of their support needs and preferences.

\section{Recommendations for Denmark}

- Introduce enterprise/entrepreneurship education and training programmes for the Humanities and other women-dominated academic disciplines.

- Reduce the vulnerability of self-employed women by tailoring family policies and business supports to better fit the needs of women entrepreneurs. This includes improving maternity policies and programme eligibility criteria.

- Develop gender-sensitive measures of entrepreneurship and entrepreneurship support.

- Educate financial advisors and providers of financial capital about women entrepreneurs' preferences and capital needs (e.g. implement policies that facilitate micro-financing and access to soft capital for women entrepreneurs).

\section{References}

Abouzahr, K., F. Taplett, M. Krentz and J. Harthorne (2018), "Why women-owned startups are a better bet", https://www.bcg.com/publications/2018/why-women-owned-startups-are-better-bet.aspx (accessed 19 June 2020).

Andersen, O., L. Laursen and J.K. Petersen (2009), "Dødelighed og erhverv 1996-2005 med et tilbageblik til 1970 [Occupational mortality with a retrospect to 1970]", Statistics Denmark.

Brush, C. G., N. M. Carter, E. J. Gatewood, P. G. Greene and M. Hart (2006), Growth-oriented women entrepreneurs and their businesses: A global research perspective, Cheltenham: Edward Elgar.

Chandramouli, D. (2018), "Study details why women entrepreneurs have greater crowdfunding success, Entrepreneur Europe, April”, https://www.entreprene.ur.com/article/312964.

Cho, Y., D. Robalino and S. Watson (2016), "Supporting self-employment and small-scale entrepreneurship: potential programmes to improve livelihoods for vulnerable workers", IZA Journal of Labor Policy, Vol. 5, No. 6, pp. 1-26.

Constantinidis, C., A. Cornett and S. Asandei (2006), "Financing for women owned ventures: Impact of gender and other owner- and firm-related variables", Venture Capital, Vol. 8, No. 2, pp. 133-157.

De Mol, E., J. Pollack and V.T. Ho (2018), "What makes entrepreneurs burn out", Harvard Business 
Review, April, https://hbr.org/2018/04/what-makes-entrepreneurs-burn-out.

European Commission (2014), Statistical data on women entrepreneurs in Europe, https://ec.europa.eu/growth/content/study-statistical-data-women-entrepreneurs-europe-0 en.

EU-OSHA (2010), "A review of methods used across Europe to estimate work-related accidents and illnesses among the self-employed", European Agency for Safety and Health at Work, pp. 3-24.

Eurostat (2016), Labour Force Survey.

Danish Chamber of Commerce (2020), "Danske kvinders iværksætteraktivitet er blandt de laveste $i$ OECD [The entrepreneurial activity of Danish women is among the lowest in OECD]", March 2020.

Grünfeld, L., S. M. Hernes and E. Karttinen (2020), "Female Entrepreneurship in the Nordics 2020. A Comparative Study", Nordic Innovation Report by Menon Economics.

Johnson, M. (2015), Precariat. Labour, Work and Politics. Routledge.

Leitch, C., F. Welter and C. Henry (2018), "Women entrepreneurs' financing revisited: taking stock and looking forward", Venture Capital: An International Journal of Entrepreneurial Finance. Vol. 20, No. 2, pp. 103-114, doi:10.1080/13691066.2018.1418624.

McKay, S., S. Jefferys, A. Paraksevopoulou and J. Keles (2012), "Study on precarious work and social rights", Working Lives Research Institute, VT/2010/084.

Neergaard, H. and C. Thrane (2011), "The Nordic welfare model: barrier or facilitator of women's entrepreneurship in Denmark", International Journal of Gender and Entrepreneurship, Vol. 3, No, 2, pp. 88-104.

Neergaard, H. and A. Weber Carlsen (2018), "When women leave corporate career to enter entrepreneurship in Denmark", Paper presented at the ISBE conference, Birmingham, 7-8 November 2018.

OECD (2019) OECD SME and Entrepreneurship Outlook 2019, OECD Publishing, Paris https://doi.org/10.1787/34907e9c-en.

OECD/EU (2018), Policy brief on women's entrepreneurship, OECD SME and Entrepreneurship Papers, No. 8, OECD Publishing, Paris, https://doi.org/10.1787/dd2d79e7-en.

Pettersson, K. (2012), "Support for women's entrepreneurship. A Nordic spectrum”, International Journal of Gender and Entrepreneurship, Vol. 4, No. 1, pp. 4-19.

Pettersson, K., H., Ahl, K. Berglund and M. Tillmar (2017), "In the name of women? Feminist readings of policies for women's entrepreneurship in Scandinavia", Scandinavian Journal of Management, Vol. 33, No. 1, pp. 50-63.

Politiken (2018), "Der er 110 år til ligeløn: Se, hvor lidt ligestillingen har rykket sig i ti år", 23 June 2018, https://politiken.dk/indland/art6600323/Se-hvor-lidt-ligestillingen-har-rykket-sig-i-ti-\%C3\%A5r.

Zahidi, S., T. Geiger and R. Crotti (2018), "The global gender gap report", World Economic Forum, www.weforum.org/reports/the-global-gender-gap-report-2018. 


\title{
Poland
}

\author{
By Ewa Lisowska, Warsaw School of Economics
}

\section{Background}

Self-employment rates for women in Poland are among the highest in the European Union, alongside Greece, Italy, Czech Republic and The Netherlands (OECD/EU, 2019). By the end of 2018, women accounted for $31 \%$ of the country's 2.97 million self-employed people, in both non-agricultural and agricultural sectors (Labour Force Survey LFS, 2019). Poland is also characterised as having the highest percentage of women employers in the European Union, with women accounting for $30 \%$ of employers (200 000) in 2018. Nevertheless, there is a substantial gender gap in the self-employment rates of women and men, $12.7 \%$ vs. $22.5 \%$ (Labour Force Survey LFS, 2019).

There are no special government policy initiatives in Poland targeted specifically at self-employed women (OECD, 2017a), which is consistent with the gender-neutral approach to policy making in Poland. Politicians argue such initiatives are not needed as women can avail themselves of the ones directed to all entrepreneurs. The Polish Agency of Entrepreneurship Development (PARP) supports small- and medium-sized enterprises, including NGOs, through institutional programmes focused on the development of entrepreneurial skills and innovation for both genders. Research conducted by PARP has shown that the main barriers specific to women entrepreneurs in Poland are a lack of entrepreneurial skills, fear of failure, and a lack of mentoring and networking (Lisowska, 2004; PARP, 2012). Consistent with this, survey data show that Polish women are less likely than men to believe that they have the skills, knowledge and experience to start a business (OECD, 2017b).

\section{Policy issue: Skills development, mentoring and networking}

Although there is no dedicated government policy for women's entrepreneurship in Poland, some women's organisations offer various types of support to help women develop their entrepreneurial skills. For example, the Women's Leadership in Business Foundation provides mentoring programmes targeted at both women and men with the goal of shaping future women business leaders. Every year, subsequent editions of these fee-paying programmes are announced in Warsaw and Poznań. ${ }^{1}$ A second initiative, Vital Voices Poland, supports the annual Global Mentoring Walk in Warsaw each March. While walking together, successful leaders meet women who aspire to become leaders or entrepreneurs. The leaders counsel and advise mentees, discuss professional challenges and share experiences. These relationships are often long-lasting, as parties keep in touch as a means for continuing to share knowledge and skills. ${ }^{2}$ Women who run their own businesses, as well as those working as employees, can participate in the initiative. Launched in 2012, the Foundation for Female Entrepreneurship is one of Poland's most comprehensive women-focused initiatives, designed to promote and develop entrepreneurship skills while also providing opportunities for networking and mentoring. ${ }^{3}$ This programme is targeted primarily at young women who are starting a business and looking for advice. Participation is free of charge, and participants receive mentoring support to refine their ideas and get started (e.g., assistance in registering the company). Participants also receive: (1) training related to business ownership and personal development in the form of a two-day entrepreneurship workshop for first time entrepreneurs; (2) networking meetings with other programme participants that allow participants to get to know each other, establish relationships and work together; (3) inspiration meetings, during which stories of successful women entrepreneurs are presented; and (4) an e-platform for networking. An annual conference, organised by the Foundation for Female Entrepreneurship, provides knowledge on current business topics and serves as a networking opportunity for approximately four hundred women who attend. The Foundation has also initiated the Black Swan Angels programme, a unique venture capital fund for women start-ups in Poland. It is worth pointing out, however, that even though there are many non-government initiatives, they do not reach everyone 
including women entrepreneurs and women who are interested in becoming entrepreneurs. These initiatives are mainly located in the biggest towns and serve the women who live there. Public policy is necessary in addressing equal opportunities for women regardless of where they live.

\section{Conclusions and recommendations}

Men are more likely to be self-employed than women in Poland. This is due, in part, to the fact that women are not encouraged educationally or socially to take the risk of owning a business. Government policy for promoting and supporting entrepreneurship among women is lacking. Similarly, government agencies at the regional level do not support women who launch businesses, nor do they provide special programmes targeted toward women entrepreneurs. Alternatively, women's organisations fill this gap by providing skills training combined with mentoring and networking opportunities. Based on the Polish experience, the following recommendations are offered to policy makers to encourage women's entrepreneurship.

\section{Recommendations for Poland}

- Embed entrepreneurial education at secondary and tertiary levels among girls and young women to increase their awareness of entrepreneurship as a career option.

- Create an e-platform for women entrepreneurs at the national level (via the Polish Agency of Entrepreneurship Development) as a means for sharing opportunities for education, training and contacts.

- Establish regionally-based Women's Business Centres to support the development of women's entrepreneurial skills training, mentoring relationships and networks.

\section{References}

Labour Force Survey LFS (2019), Aktywność ekonomiczna ludności Polski IV kwartał 2018, GUS, Warszawa.

Lisowska E. (2004), "Business Initiative of Polish Women" in Gender and Economic Opportunities in Poland: Has Transition Left Women Behind?, Report No 29205, World Bank, Warsaw, pp. 45-70.

OECD (2019), Self-employed without employees (indicator), doi: 10.1787/5d5d0d63-en (accessed on 14 March 2019).

OECD (2017a), "Inclusive Entrepreneurship Policies. Country Assessment Notes Poland 2017", http://www.oecd.org/industry/smes/POLAND-country-note-2017.pdf.

OECD (2017b), The Pursuit of Gender Equality. An Uphill Battle, OECD Publishing, Paris. http://dx.doi.org/10.1787/9789264281318-en.

PARP (2012), "Global Entrepreneurship Monitor: Poland", Polish Agency of Entrepreneurship Development and University of Economics in Katowice, Warsaw.

PARP (2011), "Women Entrepreneurship in Poland", Polish Agency of Entrepreneurship Development, Warsaw, http://badania.parp.gov.pl/files/74/75/76/479/13556.pdf. 
Notes

${ }^{1}$ www.fundacjaliderek.pl

${ }^{2}$ http://vitalvoices.pl

${ }^{3}$ https://www.siecprzedsiebiorczychkobiet.pl 


\section{Tanzania}

By Dina Modestus Nziku, University of the West of Scotland

Cynthia Forson, Lancaster University Ghana

\section{Background}

Women currently constitute over $52 \%$ of Tanzania's population (Women Gender and Development Policy, 2000; National Bureau of Statistics, 2014). Although there is no specific policy on women's entrepreneurship (Nzkiu and Henry, 2020), the Small and Medium Enterprises Development Policy of Tanzania (MIT, 2003) together with Women and Gender Development Policy (WGDP, 2000) recognises the key role women-owned enterprises play in both the private and Micro Small and Medium sector in Tanzania (Mori, 2014). According to the Ministry of Industry and Trade, the proportion of women owned enterprises in Tanzania is around $54.3 \%$ (MIT, 2012), and the majority of them are engaged in small-scale businesses, particularly in the informal sector where entry barriers are low and where the struggle for economic and social prosperity is a challenge. Given that the majority of economic activities in Tanzania and other sub-Saharan countries are in the informal sector, many Tanzanian women are working hard to feed their families, and some are providing employment opportunities to their extended families and local communities. Such activities contribute to both the local and national economy. Clearly, not all women entrepreneurs plan to work in the informal sector; rather, they are often "pushed" in this direction due to unemployment, low wages in employment and cultural attitudes

The majority of women-owned businesses (99\%) are microenterprises with fewer than five employees, and almost three-quarters have only one employee (Idris, 2018). With regard to agriculture, selfemployment is the most common form of work among rural populations, in particular rural women (Idris, 2018). Despite these problems, Tanzanian women are drawn to self-employment, and this is primarily out of necessity; a result of low wages in the formal sector and rising unemployment (Mori, 2014).

Employed women make up only $5.3 \%$ of economically active women, while $10.7 \%$ is attributed to selfemployed women and the rest, $84 \%$, are unpaid helpers (NBS, 2014). The figures for men are only slightly better at $12.8 \%, 13.8 \%$ and $73.8 \%$ respectively (Ibis). Disparities in employment also means that it is more difficult for Tanzanian women to access resources to start their own businesses (Idris, 2018).

In a 2014 study, the Food and Agriculture organisation (FAO, 2014) indicated that fewer women own land in Tanzania at a ratio of $27 \%$ to $73 \%$ men-owned; their plots tend to be smaller and they come into land ownership at a later stage in their careers. Self-employed women in agriculture earn significantly less than men, own less livestock and have less access to credit and other financial services. In the formal employment sector women are significantly more vulnerable than men ( $89 \%$ vs. $78 \%)$, and at the higher levels of employment (senior and middle management) women occupy only $17 \%$ of positions available (NBS, 2014). As such, the transition from employment or unemployment to self-employment is not an easy one.

Tanzanian women entrepreneurs face issues related to a lack of education, low specific entrepreneurial and business skills, and low levels of financial literacy. Those self-employed in agriculture have more restricted access to new technologies, training, vocational education and extension advice. This contributes to the low productivity, persistent poverty and low social status of women entrepreneurs.

\section{Policy issue: Entrepreneurship training and developing entrepreneurial mindsets}

Recognising the potential role that can be played by women through their contribution to the national economy, the Tanzanian government has taken various steps to address gender issues in recent years, introducing several policies and strategies focused on education (Development Vision 2025, 2000). The 
strategy (section 1.2.4) states that: "Education should be treated as a strategic agent for mindset transformation and for the creation of a well-educated nation to ... solve the development challenges which face the nation." The idea was to restructure and transform the education sector with a focus on promoting creativity and problem solving.

This was preceded by several gender-specific policies including Women in Development (1993), Women and Gender Development (2000) and the National Strategy for Gender Development (NSGD, 2008). These policies all proposed a new system of education geared toward enrolling more girls and establishing coeducational secondary schools to reduce the disparity between the number of girls and boys in secondary schools and higher education institutions.

None of the policies referred to above specifically mentions entrepreneurship education for women to create their own employment opportunities within their areas of specialisation. There has been recognition, however, that entrepreneurship education is crucial to the development of this creativity mindset. In 2005, the African Development bank (AfDB), the International Labour Organisation (ILO) and the Office of the Private Sector Department (OPSD) in Tanzania identified three main ways in which entrepreneurial training can be achieved among women entrepreneurs. Firstly, by exposure through the education system and formal training (Nziku, 2014), secondly in pre-start-up technical training, and finally, intermittent training during the different phases of developing and expanding a business (Stevenson and St-Onge, 2005).

A National Entrepreneurship Training Framework (NETF) was developed to outline strategies and frameworks to guide entrepreneurship education and training at varying levels of the formal and non-formal education systems (URT 2014). In formal education, it provides guidance for embedding entrepreneurship education from pre-primary through to tertiary levels of education, and at the non-formal level, it makes provision for training in business start-up, consolidation and social entrepreneurship. Poor implementation, however, means that the objectives of the NETF have not been realised. A disconnect between the general educational policy and the entrepreneurial educational framework has resulted in a failure in the envisaged integration of the NETF with the formal educational curriculum (Kalimas, 2018). This has resulted in the production of graduates who are ill-equipped to start and grow businesses yet are forced into selfemployment through necessity. Girls with higher education qualifications in specialised fields end up having to work in areas unrelated to their expertise, or become self-employed in non-cognate industries.

With regard to the pre-start-up phase, these services are usually provided by business development providers, which include NGOs. The Ministry of Industries and Trade has identified that business support services and institutions providing business training, advice and consultancy are weak and fragmented, and that there is a need to design special programmes for women (MIT, 2003; Nziku, 2014). Additionally, training and women's enterprise development seems to occur at the sectoral level and is focused on developing technical as opposed to softer business skills (Stevenson and St-Onge, 2005), although it may include some entrepreneurship training elements. Often the outcome of such training is that the women lack the skills required to start or grow a business, and follow-up support is negligent (Nziku, 2014). The women end up relying on informal networks to build informational and other resources for their businesses (Mgasa, 2014), making networking at the informal level a crucial element of business support mechanisms.

Post-start up, training needs move to the areas of marketing, product quality, financial management and business planning, yet access to this type of support is limited. This is usually due to a lack of awareness of the existence of the limited training available, cost of training and the basic and generic nature of the programmes (Stevenson and St-Onge, 2005). These issues are exacerbated for Tanzanian women who live in rural areas (FAO, 2014). However, for women who successfully complete the required training, they can support their peers (UN Women, 2016), again, pointing to the importance of women's networks for developing business skills and competences post-start up. 


\section{Conclusions and recommendations}

The Tanzanian government acknowledges the potential of women's entrepreneurship to make a significant contribution to local communities as well as to the national economy. However, a lack of education, business and entrepreneurial skills holds women back from starting and/or growing businesses. Although the Tanzanian government has developed policies and support initiatives to address gaps in entrepreneurial education and business training, dissonance between policy and implementation, fragmentation of provision, poor access, and cost and programme limitations undermine women's ability to develop their human capital to achieve their business objectives. The recommendations below should help policy makers to improve entrepreneurial human capital and education for women entrepreneurs in Tanzania.

\section{Recommendations for Tanzania}

- Ensure substantive resources and supports are available to integrate and contextualise the National Entrepreneurship Training Framework into the educational system at all levels to produce entrepreneurially educated women graduates with business skills.

- Ensure business training and support programmes specifically tailored for women are available and accessible regionally and nationally.

- Promote and support the development of women business networks to encourage peer-to-peer knowledge exchange and mentorship among women entrepreneurs.

\section{References}

FAO (2014), "Tanzania Mainland country profile: gender inequalities in rural employment in Tanzania Mainland, an overview", Rome.

Idris, I. (2018), "Mapping women's economic exclusion in Tanzania”, K4D Helpdesk Report, Institute of Development Studies, Brighton, United Kingdom.

Kalimasi, P. (2018), "Assessment of Entrepreneurship Education Trends in the Formal Education System in Tanzania," Business Management Review, Vol. 21, No. 2, pp. 53-65.

Mgasa, D. B. (2014), "Women Entrepreneurship In Tanzania: A Case Study Of Dairy Production And Marketing In Babati," Thesis Submitted For The Partial Fulfilment of the MSc International Development Wageningen University; Netherlands, https://edepot.wur.nl/312965 (accessed 24 June 2020).

MIT (2003), "Small and Medium Enterprises Development Policy," Ministry of Industries and Trade, United Republic of Tanzania, https://www.mit.go.tz/uploads/documents/en/1455890063-SMEDevelopment-Policy.pdf (accessed 24 June 2020).

Mori, N. (2014), "Women's entrepreneurship development in Tanzania: Insights and recommendations", International Labour Office - Geneva: ILO.

NBS (2014), "Tanzania United Republic of - Integrated Labour Force Survey 2014: Analytical Report", National Bureau of Statistics, Tanzania.

Nziku, D.M. and C. Henry, (2020), "Policies for supporting women entrepreneurs in developing countries: The case of Tanzania", Journal of Entrepreneurship and Public Policy, Vol. 10, No. 1, pp. 38-58.

Nziku, D. (2014), “Tanzania Female Entrepreneurship: Strategies for Sustainability and Growth” Doctoral Thesis, Southampton Solent University (SSU), United Kingdom.

OECD/EU (2018), "Policy Brief on Women's Entrepreneurship", OECD SME and Entrepreneurship Papers, No. 8, OECD Publishing, Paris, https://doi.org/10.1787/dd2d79e7-en. 
Stevenson, L. and A. St-Onge (2005), "Support Growth-Oriented Women Entrepreneurs in Tanzania", International Labour Organisation (ILO): Geneva - Switzerland.

The United Republic of Tanzania (URT) (2008), "National Strategy for Gender Development (NSGD)", Ministry of Community Development Gender and Children.

The United Republic of Tanzania (URT) (2000), "Tanzania Development Vision 2025”.

The United Republic of Tanzania (URT) (2000), "Women and Gender Development Policy" Ministry of Community Development, Gender and Children.

The United Republic of Tanzania (URT) (2014), National Education and Training Policy, Ministry of Education Science and Technology, Dar es Salaam, in Kalimasi, P. (2018) Assessment of Entrepreneurship Education Trends in the Formal Education System in Tanzania, Business Management Review, Vol. 21, No. 2, pp. 53-65.

United Nations Women (2016), "Empowering Young Women Entrepreneurs in Tanzania", http://www.unwomen.org/en/news/stories/2016/8/empowering-young-women-entrepreneurs-intanzania (accessed on 3 March 2019). 



\section{Facilitating women entrepreneurs' access to financial capital}

Accessing business start-up and growth capital poses major challenges to all entrepreneurs, however there is evidence of gender gaps in financial markets. To some extent these gaps can be explained by the types of businesses that women tend to operate but there is also evidence of biases in investment and lending decisions. This chapter briefly discusses several of the barriers faced by women entrepreneurs and the policy approaches used to overcome these market failures. Eight policy insight notes are included from Ethiopia, Ireland, Italy, Mexico, Norway, South Africa, Spain and the United States. They present the range of challenges and lessons for policy makers in developing and developed countries. 


\section{There are barriers to finance on both the supply- and demand-side}

Access to financial capital is widely recognised as one of the most pressing challenges faced by women entrepreneurs (OECD/EU, 2018). Women typically launch their firms with smaller amounts of financial capital than men, and are more reliant on internal rather than external sources of capital (Coleman and Robb, 2016). Women also face challenges in their attempts to secure growth capital in the form of debt and equity. This is due to a variety of factors, including gender bias in bank lending practices, investor preferences for STEM-based industries in which women tend to be under-represented, and the existence of networks dominated by men that have the effect of excluding women entrepreneurs and investors (Brush et al., 2014; OECD/EU, 2018). Simultaneously, women tend to be less secure in their entrepreneurial and financial skills than men, thus resulting in lower levels of confidence and a greater fear of failure (OECD/EU, 2019).

Taken together, these supply- and demand-side constraints represent significant barriers to the launch and growth of women-owned firms, and provide ample justification for policy intervention in the area of access to financial capital (Coleman et al., 2019).

\section{The role of public policy}

A growing number of public policy instruments are used to improve women entrepreneurs' access to financial capital. Traditionally, governments have often used grants to support women-led enterprises. The typical grant schemes use some form of selection mechanism (e.g. an application, business plan or idea competition) to award funds to women entrepreneurs who have a reasonable chance of success. Grants do not need to be repaid by the entrepreneur, but might have conditions attached to them (e.g. the business must be in operation for at least two years). However, governments are increasingly moving away from grants to repayable instruments. In addition to recovering the public funds, repayable instruments provide a greater incentive for entrepreneurs to be successful in their businesses since they need to repay the borrowed money.

Microcredit is one of the most common types of repayable support for women entrepreneurs. This type of finance aims to improve financial inclusion by overcoming market and social barriers in the financial market for disadvantaged groups. Data from the European Microfinance Network indicates that approximately $40 \%$ of microcredit loans go to women, and about one-third of microfinance institutions are specifically focussed on women. These loans are for less than EUR 25000 and are often packaged with financial education and business advice. The advantage of microcredit is that, as a credit product, entrepreneurs have strong incentives for creating a sustainable business since they must repay the loan. Another advantage is that, unlike other financial products (e.g. loan guarantees, bank loans), the instrument is designed specifically for the needs of people who experience difficulties in the credit market.

Another important trend is the growing number of tailored financial products for women entrepreneurs who operate growth-oriented businesses. These include programmes that seek to improve access to angel investments and risk capital - including schemes that match entrepreneurs and investors, and schemes that make equity investments in women-owned businesses - as well as initiatives that support the development of business angel networks and increasing the number of women involved in making lender and investment decisions.

Other new financial instruments and platforms are emerging, including the use crowdfunding or public procurement. These offer policy makers an opportunity to increase reach, since entrepreneurs can typically access the relevant platforms through computers or mobile phones. Another benefit is that they can have low operating costs since intermediaries are largely eliminated from the process of providing finance. 


\section{Lessons from the policy cases}

The eight policy insight notes that follow provide examples of policies and practices designed to increase women entrepreneurs' access to financing using various policy instruments. Some are designed to address supply-side structural barriers and market imperfections that restrict the flow of capital to women-owned firms. Interventions of this type help to re-shape the entrepreneurial ecosystem in ways that will make markets more inclusive and welcoming to women entrepreneurs. One such example in the collection is Innovasjon Norge (Innovation Norway), which "manages public policy efforts on entrepreneurship" and has the goal of committing at least $40 \%$ of business-targeted funds to women. Similarly, Ireland's Competitive Start-Fund for Female Entrepreneurs specifically targets women launching firms in areas typically dominated by men.

Other policy and practice measures address demand-side challenges in the areas of entrepreneurial skills, financial literacy and financial confidence. Though sometimes viewed as "fix the women" remedies, such measures serve as a means for helping women entrepreneurs acquire knowledge, skills and networks essential to achieving their goals. As an example, Spain's Women's Entrepreneurship Support Programme provides micro-credit without guarantees coupled with advice through Chambers of Commerce, an online portal and follow-on advisory services. Mexico's National Entrepreneur's Institute provides both programmes and funding targeted at women entrepreneurs. Two such programmes are Women Moving Mexico which offers entrepreneurial training and advice through seven centres, and SME Women which has provided funding to almost 10000 women-led companies.

Overall, the eight policy insight notes in this section demonstrate a strong level of commitment to increasing women entrepreneurs' access to financial capital. They show a collective sense of urgency, energy and drive to "stretch" entrepreneurial ecosystems in ways that will benefit women in their pursuit of financial capital to launch and grow their firms. The notes show that countries have implemented a broad array of financing-focused policies and practices designed to achieve that goal. However, they also suggest that much more needs to be done since women continue to encounter both structural and attitudinal barriers.

The notes highlight several takeaway messages for policy makers:

1. A strong policy framework should be put in place for access to finance measures. A policy framework setting out objectives, targets, activities, responsibilities and budgets serves as a guide for programmes, supports coherence and consistency, and helps to ensure that initiatives will not be eliminated in the face of economic or political fluctuations. Although all eight of these notes provide practice examples, some report that there is no robust country-level policy to increase women entrepreneurs' access to financial capital (Ireland, Mexico, South Africa). In other instances, practice appears to be inconsistent with policy due to the imposition of programme requirements that serve as barriers for women (Ethiopia).

2. "Gender-blind" access to finance programmes may not be sufficient to address gender gaps in financial markets. Measures need to address the different motivations, circumstances and contexts of women entrepreneurs compared with men. Several of the notes challenge the assumption that financing programmes and sources that work for men entrepreneurs will work just as well for women. A number challenge us to take the different motivations, profiles and contexts of women entrepreneurs into consideration in the design of financing policy and practice (Italy, Ireland). The notes also call for dedicated funding and programmes or designated quotas for women entrepreneurs (Mexico, Norway, South Africa).

3. A variety of funding instruments needs to be made available. Governments are making a growing and diverse array of funding sources available to women entrepreneurs, either directly or indirectly. These sources include grants (Norway), microcredit (Spain), loans (Ethiopia), equity (Ireland) and newer sources such as crowdfunding (United States). The notes attest to the notion that "one size does not fit all" by highlighting financial policies and programmes that address different profiles of 
women entrepreneurs such as those launching necessity-based or lifestyle firms (Ethiopia, Mexico, Spain, South Africa) as well as those launching growth-oriented firms in STEM and other innovative fields (Ireland, Italy, Norway, United States).

\section{References}

Brush, C. G., P. G. Green, L. Balachandra and A. Davis (2014), "Executive Summary: Women Entrepreneurs 2014: Bridging the Gender Gap in Venture Capital", Arthur M. Blank Center for Entrepreneurship, Babson College, Babson Park, MA, https://www.babson.edu/media/babson/siteassets/content-assets/about/academics/centres-and-institutes/blank-institute/global-research/dianaproject/diana-project-executive-summary-2014.pdf.

Coleman, S. and A. Robb (2016), "Financing high-growth women-owned enterprises: Evidence from the United States" in C. Díaz-García, C. Brush, E. Gatewood and F. Welter (eds.), Women's Entrepreneurship in Global and Local Contexts, Edward Elgar Publishing, Cheltenham, UK and Northampton, MA, pp. 183-202.

Coleman, S., C. Henry, B. Orser, L. Foss, and F. Welter (2019). "Policy Support for Women Entrepreneurs' Access to Financial Capital: Evidence from Canada, Germany, Ireland, Norway, and the United States," Journal of Small Business Management, Vol. 57, No. 2, pp. 296-322.

OECD/European Union (2019), The Missing Entrepreneurs 2019: Policies for Inclusive Entrepreneurship, OECD Publishing, Paris, https://doi.org/10.1787/3ed84801-en.

OECD/EU (2018), "Policy Brief on Women's Entrepreneurship", OECD SME and Entrepreneurship Papers, No. 8, OECD Publishing, Paris, https://doi.org/10.1787/dd2d79e7-en. 


\section{Ethiopia}

By Atsede Tesfaye, Addis Ababa University

\section{Background}

Ethiopia is a low-income country and the second most populous country in sub-Saharan Africa (SSA), with an estimated population of around 115 million in 2020 (UN, 2019). The country developed and revised its Micro and Small Enterprise (MSE) policy in 2011 in order to support the growth of micro and small businesses (MoUDH, 2012). The policy focuses mainly on sustainable job opportunities for the unemployed, and identifies women entrepreneurs as one of the target groups. Additionally, gendersensitive policies, such as the revised Family Code 2000, have facilitated access to resources and the removal of restrictions on employment for women. These polices have helped provide opportunities for women to engage in entrepreneurship which was once considered to be solely a man's domain. However, despite advancements in women's entrepreneurship, women tend to be less successful than men due to difficulties associated with access to finance, land, education, training and effective business networks (World Bank, 2015).

\section{Policy issue: Microfinance is restrictive; greater access to financial services is needed}

Despite the existence of the MSE policy and Family Code, as well as various initiatives aimed at promoting women's entrepreneurship, access to finance for women entrepreneurs remains a complex issue. Credit guarantee funds established by regional governments have enabled Micro Financial Institutions (MFIs) to provide loans without collateral requirements. In this regard, the MSE policy states that "Micro Financial Institutions (MFIs) shall be the sole providers of saving and credit services to MSEs, as per standard procedures to be established for this purpose, and no other form of credit is to be provided" (MoUDH, 2012). Furthermore, borrowers are required to save at least $20 \%$ of the loan, and the loan repayment period cannot exceed 36 months. These restrictive policies create obstacles to acquiring capital for starting and growing businesses. In addition to MFIs, banks provide access to loans but their collateral requirements are a barrier. Data from the 2015 Ethiopia Enterprise Survey indicate that access to finance is one of the top three business environment obstacles for all entrepreneurs in Ethiopia (World Bank, 2016), with only $12.9 \%$ of businesses in Ethiopia receiving bank finance in 2016.

While collateral and saving requirements are common challenges for both men and women entrepreneurs, women have less access to financial services when compared to their male counterparts. This includes chequing and saving accounts and formal credits (Central statistics and ICF international, 2017). One of the main barriers for women is restrictive social attitudes related to traditional normative gender roles and power relations (Central Statistical Agency and ICF International, 2017). The traditional view of women is that they are subordinate to their husbands, and that men are the income earners in households. Indeed, due to this cultural view in many cases, properties are registered in the husband's name, and major decisions, including finance and buying property, are often made by husbands. Regardless of the Family Code (2000), which provided women with collateral to gain access to finance, accessing finance without the support of a husband is difficult.

Traditional culture and religious institutions convey hierarchies of gender and seniority that urge women to be obedient to their husbands (Malara and Boylston, 2016). Moreover, domestic violence is one way of maintaining power in a relationship and retaining control over financial resources (Hailemariam et al., 2019). A systematic review of studies found that about $67 \%$ of women in Ethiopia experienced domestic violence by their husband or intimate partner (Semahegn and Mengistie, 2015). Thus, gendered sociocultural factors limit the financial autonomy of women to fulfil collateral and saving requirements. As a consequence, women-operated MSEs suffer from inadequate capital investment, and operate with no or insufficient access to loans (Wasihun and Paul, 2010). Many women entrepreneurs rely on iqqub 
(traditional Indigenous informal financial institutions functioning as rotating savings and credit associations) for the start-up and development of their businesses (Solomon, 2010; Anley, 2017).

The MSE strategy policy also states that "priority sectors and enterprise types shall be offered better loan conditions, including lower interest rates and full coverage of loan guarantees" (MoUDH, 2012). Sectors prioritised for government support are manufacturing, construction, and enterprises that produce items for export or to substitute imports. However, only a few women entrepreneurs engage in these men dominated sectors. For example, in the WEDP registration database as of July 2016 , about $10 \%$ of women were found to be operating their businesses in these sectors (Alibali et al., 2017). Socialisation experiences, education, limited starting capital, and the gendered expectations that society puts on them are just some of the challenges facing women who seek to engage in these sectors. Overall, the restrictive MSE policy and demanding savings requirements tend to limit women entrepreneurs' ability to access loans in order to start and grow their businesses in their chosen sectors.

\section{Conclusions and recommendations}

Despite the above challenges, reports show that the highest rate of total early-stage entrepreneurial activity $^{1}$ (TEA) for women is found in SSA at $21.8 \%$ compared to $17.3 \%$ in Latin America and $6 \%$ in Europe (GEM, 2019). Women entrepreneurs in Ethiopia have been able to grow their micro enterprises into small enterprises in the formal sector (Solomon, 2010). Ethiopia is among one of the five economies in SSA where the proportion of people running established businesses is equal for both men and women. Compared to countries in the region where there are fewer women than men at this business stage, such as in Botswana and Malawi (Kelley et al., 2013). This may be due to entrepreneurs' abilities and willingness, as well as enablers in the environment (Kelly et al., 2013). Two financial initiatives specifically targeted at women entrepreneurs were recently introduced. The Women Entrepreneurship Development Project (WEDP) is backed by the World Bank's fund and was launched in 2012 for the poorest countries. It provides a special line of credit for selected urban women entrepreneurs forming and developing a venture in the formal small and medium enterprise sector. The Enat Bank is a bank established by women investors in Ethiopia and was launched in 2013. The bank offers access to credit for women who do not have the financial capacity and assets to submit collaterals. Other than these initiatives, the organisation for Women in Self Employment (WISE) provides saving and credit services to economically disadvantaged women and girls who aspire to improve their livelihood by becoming self-employed. However, these initiatives target only a few women entrepreneurs specifically in selected urban areas. Based on the Ethiopian experience, the following recommendations are offered to policy makers seeking to improve access to finance for women entrepreneurs.

\section{Recommendations for Ethiopia}

- Microfinance policies need to make loans available to a large number of women entrepreneurs who have no savings or access to collateral. Access to finance for credit-worthy entrepreneurs could be based on the implementation of psychometric credit assessment tools and a viable business plan.

- Governments should encourage all banks to earmark a certain percentage of their investment for women-owned enterprises through making tax incentives available for this purpose.

- Non-governmental organisations, such as women entrepreneur associations and networks, should be utilised to provide credit schemes to women entrepreneurs. 


\section{References}

Alibhai, S., N. Buehren, S. Papineni and R. S. Pierotti (2017), "Crossovers: female entrepreneurs who enter male sectors - evidence from Ethiopia”, Policy Research Working Paper No. 8065, The World Bank Group, Washington, DC.

Anely, Y. S. (2017), "Contextualizing entrepreneurial networks in Ethiopia: the case of the Ekubs of the Gurage ethnic group", in M. R. Pasillas, B. Ethel and M. Markowska, M. (eds.), Contextualizing Entrepreneurship in Emerging Economies and Developing Countries, Edward Elgar Publishing, Cheltenham.

Central Statistical Agency and ICF International (2017), "2016 Ethiopia Demographic and Health Survey Key findings", Addis Ababa, Ethiopia, and Calverton, Maryland.

Hailemariam, A.T., B. Kroon, M. Van Engen and M.Veldhoven (2019), "Dreams and reality: Autonomy support for women entrepreneurs in Ethiopia", Equality, Diversity and Inclusion: An International Journal, Vol. 38, No. 7, pp. 727-742.

Kelley, D et al., (2013), Global Entrepreneurship Monitor 2012 women's report, www.babson.edu/Academics/centres/blank-center/global-resarch/gem/pages/reports.aspx.

Malara, D. M. and T. Boylston (2016), "Vertical love: forms of submission and top-down power in Orthodox Ethiopia", Social Analysis, Vol. 60, No.4, pp. 40-57.

MoUDH (2012), "Micro and Small Enterprise Development Policy \& Strategy", Government of the Federal Democratic Republic of Ethiopia, Ministry of Urban Development \& Housing, Addis Ababa.

Semahegn, A. and B. Mengistie (2015), "Domestic violence against women and associated factors in Ethiopia: systematic review", Reproductive Health, Vol. 12, No. 8.

Solomon, D. (2010), "Desk review of studies conducted on women entrepreneurs of Ethiopia", Private Sector Development Hub/Addis Ababa Chamber of Commerce and Sectoral Associations.

United Nations, Department of Economic and Social Affairs, Population Division (2019), World Population Prospects 2019, Online Edition, Rev. 1.

Wasihun, R. and I. Paul (2010), "Growth determinants of women operated micro and small enterprises in Addis Ababa", Journal of Sustainable Development in Africa, Vol. 12, No. 6, pp. 233-246.

World Bank (2016), World Bank Groups Enterprise Surveys, http://www.enterprisesurveys.org/data/exploreeconomies/2015/ethiopia.

World Bank (2015), SME Finance in Ethiopia: Addressing the Missing Middle Challenge, The World Bank Group, Washington, DC.

\section{Note}

1 Total early-stage entrepreneurship activity rate estimates the share of the population involved in starting a business or managing one that is less than 42 months old. 


\section{Ireland}

By Colette Henry, Dundalk Institute of Technology and Griffith University

\section{Background}

According to the Global Entrepreneurship Monitor (GEM), one in five people in Ireland are aspiring or planning to start a business within the next three years. This means that Ireland ranks $10^{\text {th }}$ across the OECD in terms of early stage entrepreneurship, and fourth in Europe (GEM, 2020). Men are three times more likely to be self-employed than women ( $21 \%$ for men vs $7 \%$ for women) (OECD/EU, 2019), and there are currently 1.8 men for every woman who is an early stage entrepreneur (GEM, 2020). While there is growing interest in women's entrepreneurship at national and regional levels in Ireland, and growing policy awareness of the gender gap in entrepreneurship and the unique challenges facing women entrepreneurs, ${ }^{1}$ until recently, there has been no dedicated policy or strategy for women's entrepreneurship. ${ }^{2}$

The Irish Government's overarching entrepreneurship policy - the National Policy Statement on Entrepreneurship in Ireland (2014) - set out a vision for Ireland to be "amongst the most entrepreneurial nations in the world and a world class environment in which to start and grow a business" (DJEI, 2014). The policy outlined a number of key actions that needed to be taken to realise this vision, each linked to key components of the entrepreneurial ecosystem. Although the policy discussed gender throughout, there was no dedicated section on women's entrepreneurship. Women were positioned as part of a broad underrepresented or disadvantaged group, with untapped entrepreneurial potential and facing particular barriers in their efforts to start and grow a business. Barriers specific to women entrepreneurs in Ireland were identified within the policy as: few role models, poor access to finance, low levels of risk taking, low selfconfidence, limited networking opportunities, and a lack of technical expertise (DJEI, 2014). In highlighting the gender gap in entrepreneurship, the policy noted that, in 2014, Irish men were much more likely than Irish women to be early stage entrepreneurs, and that women-led businesses accounted for just $7 \%$ of the State's high potential start-up (HPSU) investment.

From a gender perspective, by consistently comparing women to men, focusing supports on mendominated and growth-oriented industry sectors, and contextualising women within minority groups, Ireland's 2014 National Entrepreneurship Policy Statement could be viewed as inadvertently reinforcing the established view of women as "other", in "deficit" and needing to be "fixed" (Ahl, 2004; Henry et al., 2016; Etzkowitz et al., 2020). Accordingly, notwithstanding the presence of some valuable women-targeted support initiatives in operation on the ground ${ }^{3}$ at the time, "fixing" mechanisms proposed by the National Policy to increase women's participation in entrepreneurship (and potentially bring them up to the same level as men) were mainly in the form of soft supports such as mentoring, role models and networks. This approach did not appropriately identify and directly address the different needs of women entrepreneurs, as well as the different challenges they faced. It viewed women mainly as a homogenous group. It also did not recognise that some of the differential characteristics of women-led businesses may have reflected different sectoral choices and business models, as well as different entrepreneurial motivations, management styles and growth aspirations.

In January 2020, Enterprise Ireland introduced its Action Plan for Women in Business (Enterprise Ireland, 2020), Ireland's first national government agency strategy to focus exclusively on women entrepreneurs. In contrast to the 2014 National Policy Statement, the Plan acknowledges the multiple and complex factors contributing to women's under-representation in economic development. Its aim is to promote gender diversity more broadly - in leadership, senior management and board level roles - in order to increase the participation of women founding, leading and growing enterprises. The Plan sets out four key objectives and a total of 24 actions specifically designed to increase the number of: women-led established companies growing internationally; women in middle and senior management roles; aspiring women 
entrepreneurs, and women-led HPSUs. The Action Plan is a welcome development in women's entrepreneurship support; it will be interesting to see how it is incorporated into the Government's overarching National Policy Statement on Entrepreneurship (2014), which is due to be updated, and more importantly, how it impacts on women's entrepreneurial aspirations, especially in light of the COVID-19 crisis.

The recently published Entrepreneurship and SME Growth Plan (DETE, 2021) is another welcome addition to Ireland's general entrepreneurship policy agenda. While not including a specific focus on women's entrepreneurship ${ }^{4}$, the report maps out an ambitious long-term strategic blueprint beyond COVID-19 for all SMEs and entrepreneurs. The report offers recommendations in four key areas: Entrepreneurship; Productivity, Digitalisation and Competitiveness; Internationalisation; and Clustering and Networks. The recommendations in the Growth Plan will be reviewed and taken forward, as appropriate, by a Ministerialled SME and Entrepreneurship Implementation Group during 2021, in conjunction with relevant Departments and Agencies.

\section{Policy issue: Women entrepreneurs continue to struggle accessing start-up finance}

Although the rate of informal investment increased in Ireland during 2019 (to 5.6\%), it is still below the OECD average of $6.3 \%$ (GEM, 2020). Currently, less than $10 \%$ of venture capital funding in Ireland goes to women-founded companies (Enterprise Ireland, 2020). This could be because, in Ireland, men are more likely than women to be investors - whether formal or informal (GEM, 2020). Furthermore, micro and smaller enterprises tend to make less use of external financing instruments than their larger peers (OECD/EU, 2019), and the majority of women's businesses fall into this category. This is also the case for low-tech ventures that could be perceived as having low or no growth potential. In Ireland, the majority of women's businesses are in the consumer services (60\%), with very few women reporting being involved in medium or high-tech businesses ( $4 \%$ women compared to $12 \%$ men) (GEM, 2020).

Within Irish entrepreneurship policy, access to finance is recognised as a critical issue for all businesses, especially at the start-up and growth stages. There is also increasing recognition that women entrepreneurs face greater challenges than their male counterparts in accessing financial capital (OECD, 2016; OECD/EU, 2019; Coleman et al., 2019). This is often attributed to women having shorter credit histories and less collateral; being less aware of financial supports; being less inclined to approach formal capital providers with substantive investment projects; being less financially secure and relying more on their own funding than their male counterparts (OECD/EU, 2019). At start-up, Irish entrepreneurs especially women - have tended to rely on bank loans and cash flow to get their businesses off the ground (DJEI, 2014). Both these sources were adversely affected by the 2008 recession ${ }^{5}$ (The Irish Times, 2016). Over the last few years, a number of policy reports and action plans have been introduced to improve the availability and range of finance to entrepreneurs. These include: The Joint Committee on Jobs, Enterprise and Innovation's Report on access to finance for small and medium enterprises (July, 2014); the National Policy Statement on Entrepreneurship in Ireland (October, 2014) discussed above; the Action Plan for Jobs (APJ) (January, 2015), and the Joint Committee on Jobs, Enterprise and Innovation's Report on key issues for women entrepreneurs (July, 2015). Collectively, these reports highlighted the need for a wider range of financing options; recommended developing the non-banking sector to fund SME growth, and suggested that Credit Unions could play a greater role in supporting SMEs. Specific recommendations with regard to women entrepreneurs included: increasing the number of competitive start funds; establishing a women seed and early seed capital fund; creating business angel networks managed by women, and introducing a national financial mentoring scheme for women entrepreneurs.

Consistent with the recent Entrepreneurship and SME Growth Plan (DETE, 2021), Ireland's current National Entrepreneurship Policy (2014) - which, at the time of writing, had been reviewed but not formally updated (DBEI, 2018) ${ }^{6}$ - places considerable focus on financial support, with a dedicated section on finance. The 2014 policy outlines the various types of finance available, including bank lending, micro- 
finance and credit guarantee schemes, venture capital, EU initiatives, and alternative and innovative sources of finance. It identifies a series of specific actions in relation to improving access to finance for entrepreneurs, which focus mainly on competitive funding. Most are targeted at all entrepreneurs. Only one is dedicated to women entrepreneurs specifically - the Competitive Start-Fund for Women Entrepreneurs (CSFWE). The CSFWE is focused on business ideas and early-stage start-ups that have the potential to become HPSUs in the manufacturing and internationally-traded services, including a broad range of sub-sectors in Agtech, Cleantech, Fintech, Software, Lifesciences, Food, and Medical, Digital and Renewable Technologies. Most of these sectors are not among those typically dominated by women. Eligible projects must be capable of becoming "high potential start-ups", generating sales of EUR 1 million and creating ten new jobs within three years. Applicants must have revenues of less than EUR 100000 and not be in receipt of other equity investment (more than EUR 150000 ) prior to applying. A maximum of EUR 50000 is available to successful applicants, delivered in two equal tranches for $10 \%$ shareholding by the State agency. Successful applicants are required to secure EUR 5000 cash investment before funds are awarded; ten mentoring sessions are also provided.

Information evenings for potential applicants are held in Business Innovation Centres (BICs) in Dublin, Cork, the South East and West of the country, and successful applicants take part in the Dublin BIC's accelerator programme over a twelve week period. This type of arrangement may not suit all women entrepreneurs, especially those with childcare responsibilities or those based in rural areas. That said, Enterprise Ireland's new Action Plan for Women in Business (Enterprise Ireland, 2020) promises to not only improve the financial landscape for women entrepreneurs, but also to ensure all of their support programmes are designed to maximise women's participation.

\section{Conclusions and recommendations}

Policy makers in Ireland have paid increasing attention to the gender gap in entrepreneurship (including among high-potential start-up founders) and highlighted major obstacles (including access to finance). The need to exploit untapped women's entrepreneurial potential is included in strategic documents, along with a recent stated commitment to the promotion of women's entrepreneurship (Enterprise Ireland, 2020). However, the availability of financial support dedicated to women entrepreneurs remains limited. While the CSFWE has been successful in raising the number of women-led HPSUs (DBEI, 2020), it continues to be focused on growth-oriented, internationally-traded businesses and does not cover the typical sectors and business sizes in which women operate. More and broader funding initiatives dedicated to women entrepreneurs are needed. The following recommendations are offered for policy makers seeking to improve access to finance for women entrepreneurs.

\section{Recommendations for Ireland}

- Increase the number of dedicated funds for women entrepreneurs.

- Widen the range of eligible sectors and business categories that can receive mainstream finance support to include those in which women typically operate and/or predominate, including those with modest growth trajectories and those focusing on the domestic market.

- Contextualise and stagger high potential start-up targets to avoid high growth targets being seen as unrealistic or unachievable - and hence off-putting - to early-stage women entrepreneurs.

- Ensure substantive financial support packages are accessible to women entrepreneurs in all regions of the country, especially in rural and remote areas. 


\section{References}

Ahl, H. (2004), The Scientific Reproduction of Gender Inequality, CBS Press, Copenhagen.

Coleman, S., C. Henry, B. Orser, L. Foss and F. Welter (2019), "Policy Support for Women Entrepreneurs' Access to Financial Capital: Evidence from Canada, Germany, Ireland, Norway, and the United States", Journal of Small Business Management, Vol. 57, No. S2, pp. 296-322.

DBEI - Department of Business, Enterprise and Innovation (2018), "The National Policy Statement on Entrepreneurship Mid-term Review”, Entrepreneurship and Small Business Policy Unit, Indigenous Enterprise Division, February, https://dbei.gov.ie/en/Publications/Publication-files/National-PolicyStatement-on-Entrepreneurship-Mid-Term-Review.pdf (accessed 8 July 2020).

DBEI - Department of Business, Enterprise and Innovation (2020), "Female Entrepreneurship posting on website", https://dbei.gov.ie/en/What-We-Do/Business-Sectoral-Initiatives/Entrepreneurship-/FemaleEntrepreneurship/ (accessed 8 July 2020).

DETE - Department of Enterprise Trade and Employment (2021), "Report of the SME Taskforce: National SME and Entrepreneurship Growth Plan: An ambitious long-term strategic blueprint for Irish SMEs and entrepreneurs, https://www.gov.ie/en/publication/e19ff-report-of-the-sme-taskforcenational-sme-and-entrepreneurship-growth-plan/ (accessed, 15 ${ }^{\text {th }}$ April 2021).

DJEI - Department of Jobs, Enterprise and Innovation (2014), "National Policy Statement on Entrepreneurship in Ireland", https://dbei.gov.ie/en/Publications/National-Policy-Statement-onEntrepreneurship-in-Ireland-2014.html (accessed 4 February 2019).

Enterprise Ireland (2020), "Enterprise Ireland 2020 Action Plan for Women in Business: Fuelling growth through diversity", https://www.enterprise-ireland.com/en/Publications/Reports-PublishedStrategies/Action-Plan-for-Women-in-Business.pdf (accessed 6 July 2020).

Etzkowitz, H., C. Kemelgor and L. M. Kehl (2020), "Gender Equity and Equality: Resistance and Advance in Academic Science and Innovation" in H. Lawton Smith, C. Henry, H. Etzkowitz and A. Poulovassilis (eds.), Gender, Science and Innovation: New Perspectives, Edward Elgar: Cheltenham, pp. 380-404.

GEM (2020), "Entrepreneurship in Ireland 2019 - The 2019 Survey of Entrepreneurship in Ireland", Department of Business, Enterprise and Innovation, https://www.gemireland.com/wpcontent/uploads/2020/06/GEM-2019.pdf (accessed 6 July 2020).

Henry, C., L. Foss and H. Ahl (2016), "Gender and entrepreneurship research: A review of methodological approaches”, International Small Business Journal, Vol. 34, No. 3, pp. 217-241.

OECD (2019), SME and Entrepreneurship Policy in Ireland, OECD Studies on SMEs and Entrepreneurship, OECD Publishing, Paris, https://doi.org/10.1787/e726f46d-en (accessed 6 July 2020).

OECD (2016), "Supporting Women Entrepreneurs in Ireland: Rapid Policy Assessments of Inclusive Entrepreneurship Policies and Programmes", http://www.oecd.org/ireland/RPA-Ireland-womenFINAL.pdf, (accessed 8th July 2020).

OECD/European Union (2019), The Missing Entrepreneurs 2019: Policies for Inclusive Entrepreneurship, OECD Publishing, Paris, https://doi.org/10.1787/3ed84801-en.

The Irish Times (2016), "Irish SMEs still Worried About Access to Finance", http://www.irishtimes.com/business/economy/irish-smes-still-worried-about-access-to-finance1.2498134 (accessed 8 June 2017). 


\section{Notes}

1 See, for example: Houses of the Oireachtas (2015), Joint Committee on Jobs, Enterprise and Innovation, Report on Key Issues for Female Entrepreneurs in Ireland and for their Participation in the Tech Sector, July, 2015, 31 JEI 018; OECD/EU (2016), Supporting Women Entrepreneurs in Ireland: Rapid Policy Assessments of Inclusive Entrepreneurship Policies and Programmes.

${ }^{2}$ See Enterprise Ireland (2020), Enterprise Ireland 2020 Action Plan for Women in Business: Fuelling growth through diversity.

${ }^{3}$ Led by Enterprise Ireland and its network of local enterprise offices.

${ }^{4}$ In recommendation 1.15 (p.21) of the report, reference is made to maximising the entrepreneurial potential of all demographic groups, especially "those with untapped entrepreneurial potential, e.g. women, retuned emigrants, immigrants, youth, those aged $50+$ and those living in rural environments."

5 Ireland was the first Eurozone country to go into recession in 2008; it recovered slightly and then dipped again at the end of 2012 and at the beginning of 2013. The Irish property market crumbled, top Irish banks were on the verge of collapse and unemployment grew. International bailouts totalling EUR 67 billion were provided in 2013 to aid recovery, and by 2016, Ireland's economy was reported to be growing at a rate of $7 \%$, on a par with China.

${ }^{6}$ As noted by the OECD (2019a), a number of other enterprise strategy and policy documents have been issued in Ireland since 2014, and while they consider entrepreneurship in the context of new venture creation, they focus mainly on existing businesses, strengthening their resilience in the face of global challenges, continuing the focus on export-led growth strategies, and promoting innovation. (See, for example, Innovation 2020; Ireland Connected; Enterprise 2025; Enterprise 2025 Renewed: Building resilience in the face of global challenges). 
Italy

\author{
By Sara Poggesi, University of Rome Tor Vergata \\ Michela Mari, University of Rome Tor Vergata \\ Luisa De Vita, Sapienza University of Rome
}

\title{
Background
}

In Italy, women's employment situation and their role within the family are key determinants of their level of entrepreneurial engagement. In 2019, women's employment rate in Italy (population 20-64 years) was $53.8 \%$, compared to men's employment rate of $73.4 \%$ (Eurostat, 2019). These data are particularly alarming because they show that Italy has one of the lowest employment rates for women in the European Union, where the average rate for women stands at $68.7 \%$. Similarly, Italy also faces one of the highest gender employment gaps between women and men; 19.6 percentage points (p.p.) versus 11.4 p.p. (Eurostat, 2019). As an added disadvantage, when Italian women are employed, they tend to be overrepresented in non-standard and precarious work where they face greater difficulties than men in terms of career progress (World Economic Forum, 2020). This can be explained, in part, by structural and cultural barriers that limit women's participation in the labour market as well as their career opportunities (e.g. Bettio and Plantenga, 2004).

Italian women also face a gendered division of labour within the family. Due to the persistence of stereotypical gender roles (e.g. León and Migliavacca, 2013; Saraceno, 2016) that categorise men as "breadwinners" and women as "caregivers", Italy has one of the worst gender imbalances in terms of unpaid care (OECD Stat, 2017). Italian women spend, on average, 5 hours and 10 minutes in unpaid work, against 2 hours and 18 minutes spent by men. This represents the largest gap among EU countries, with the sole exception of Portugal. The discrepancy is exacerbated due to the effects of the COVID-19 pandemic that has suddenly increased workloads, especially for women. Recent surveys have shown that the $68 \%$ of Italian working women with a partner spent more time on housework during the lockdown period than before, and that this trend is anticipated to continue post-lockdown (InGenere, 2020).

The substantial difficulties in the Italian labour market for women help to explain why so many Italian women choose an entrepreneurial path. Italian data on self-employed women (with or without employees) are significantly higher than the OECD average (OECD, 2016), and women-owned firms constitute $21.9 \%$ of the country's overall population of firms (Unioncamere, 2019). According to the OECD (2016), Italian women tend to be "pushed" by necessity motivations (e.g. in order to better manage work and family life, Poggesi et al., 2017) rather than "pulled" (e.g. from personal ambition, need for achievement) into entrepreneurship. The fact that necessity is a major driving force for women-owned firms in ltaly results in a concentration of firms in low value-added and low innovation-oriented sectors, such as retail, healthcare and education. Nevertheless, similar to other developed countries, Italy has witnessed an increasing number of women launching, operating and funding start-ups and small and medium-sized enterprises (SMEs) in traditional men dominated sectors, such as scientific, professional and technical activities (Unioncamere, 2019). In these categories, the percentage of women-led start-ups in Italy is $12 \%$ compared to $9 \%$ in France and $11 \%$ in Germany (Italian Equal Opportunities Department, 2020).

As is the case in most nations, women-led start-ups are under-represented in high tech. In the case of Italy, this paucity of innovative high tech women-led start-ups can be explained by the educational path pursued by most women. According to Censis data (2019), women graduates in Italy represent $56 \%$ of the total, and $59.3 \%$ of students enrolled in doctoral programmes, specialisation courses, or masters' degrees. In terms of degree focus, however, women are more likely to have a background in the humanities as opposed to focusing on economics, finance, or STEM fields during their studies (Unesco, 2017). Gender 
differences in employment opportunities combined with homecare responsibilities and different educational paths help explain why pursuing an entrepreneurial career may represent a feasible alternative for Italian women to achieve both personal and economic goals. This, in turn, calls for a growing awareness and responsibility on the part of Italian policy makers to capitalise on women's skills, foster their entrepreneurial intentions, and sustain women-led firms. Consistent with this, financing is one of the key issues that policy makers need to consider, since it has a major role in determining the decision to start an entrepreneurial venture, as well as the decision to make it grow over time.

\section{Policy issue: Financing women-owned firms}

Although access to finance is globally recognised as a crucial element for launching a business and for sustaining its growth, data on Italian women entrepreneurs' access to finance are alarming. Only $4 \%$ of Italian women indicate that access to capital is not a barrier to starting a business compared to $27 \%$ of the OECD area average (OECD, 2016). These data contrast with Italian legislators' efforts, over the course of the last 30 years, to support women's entrepreneurship through measures designed to increase access to financial capital while also reducing its cost.

The first document issued under the Italian Ministry for Industry, Commerce and Craft is Law 215/1992 "Positive actions for female entrepreneurship". This policy measure provides ad hoc capital grants aimed at encouraging the creation and development of women-led firms, the acquisition of pre-existing businesses, the implementation of innovative projects and the acquisition of services, as well as the promotion of entrepreneurial training and the facilitation of access to credit for women-owned firms. Italy's policy focus on women-led firms continued in subsequent years. In 1996, the Italian Ministry of Economic Development launched a Guarantee Fund for supporting access to credit for SMEs. The fund, launched in 2000 , provides a public guarantee covering up to $80 \%$ of the loan and up to EUR 2.5 million for financial operations. Within the Guarantee Fund, a special section devoted to women's entrepreneurship was introduced in 2014. Accordingly, women-owned firms are exempted from paying the one-off fee to the Fund which, today, is between $0.125 \%$ and $1.0 \%$ of the amount financed, depending on characteristics such as the size of the firm, the region in which the firm is established and the type of project proposed. As a further measure to encourage women's entrepreneurship, legislative provisions from 2015 pertaining to the self-employment of young people were extended to include women, with no age limits, with the aim of supporting new entrepreneurs through the creation of competitive micro and small businesses while also providing better access to credit. The benefits associated with these provisions are granted on the basis of an evaluation procedure up to a maximum of EUR 200000.

In recent years, special attention has been devoted to innovative firms. In 2012 and again in 2015, legislation was enacted to stimulate entrepreneurship overall, particularly the development of innovative start-ups and innovative SMEs. As clearly stated, innovative start-ups can access the Guarantee Fund for SMEs for free. The share of the loan covered by the guarantee can be as high as $80 \%$, up to a maximum of EUR 2.5 million, with no evaluation of the business plan and balance sheets and with no additional guarantees from the bank. Innovative SMEs are entitled to several benefits, with some differences compared to innovative start-ups. For example, innovative SMEs do not have automatic access to the public guarantee. Alternatively, the Fund was charged with developing an ad hoc credit assessment process on the basis of its own rating system, excluding those companies with the lowest rating from access to credit (Ministero dello Sviluppo Economico, 2019).

In 2014, Smart \& Start Italy, the main financing programme dedicated to innovative start-ups at the national level, with a total budget of about EUR 260 million, was launched. The programme offers interest-free loans for a period of up to 10 years to innovative start-ups to cover up to $80 \%$ of investment plans and managing costs between EUR 100000 and EUR 1.5 million. The loan coverage rate rises to $90 \%$ for those start-ups launched by women and/or under 35 years old. Moreover, if the innovative start-up is based in 
Southern Italy, $30 \%$ of the funding is issued as a non-repayable grant (Ministero dello Sviluppo Economico, 2019).

In addition to these national financial initiatives, a variety of local measures aimed at promoting women's entrepreneurship in technology, innovation and scientific research have been developed. Examples include the Lazio Region "Innovazione: Sostantivo Femminile" ("Innovation: A feminine noun") project, and the partnership between the European Investment Bank (EIB) and Unicredit Bank. The first, started in 2014 and linked to the Regional Operational Program for the Lazio Region and the European Regional Development Fund for the period of 2014-20, provides funding to support the creation and development of innovative ideas and projects, while also promoting the adoption and use of new technologies in womenled firms. The second, launched in 2019, is geared toward financing projects by innovative SMEs or SMEs supporting innovation that are managed or controlled by women, through loans granted by Unicredit Bank using funds provided by the EIB. Most recently, the legislators' focus on financing has become even stronger in the wake of the COVID-19 pandemic. In line with other European countries, Italy is working to provide liquidity support for new and innovative firms through public guarantee programmes for loans provided by banks and by deferring tax payments (Ministero dello Sviluppo Economico, 2019).

What emerges from this analysis is Italian legislators' focus on measures relating to financing, but a lack of attention to other support mechanisms that could help women overcome specific barriers to starting and growing a business. These include measures to strengthen women's managerial skills, improve upon the low levels of financial education in the country (OECD, 2017), and effective measures to support work-life balance for women who are responsible for a greater share of family care (Carta, 2019).

\section{Conclusions and recommendations}

There is no doubt that attention must be paid to financing in order to foster the start-up stage as well as the development of both traditional and innovative firms. However, a "step forward" in supporting women entrepreneurs' initiatives needs to be taken. Based on the Italian experience, the following recommendations are offered to policy makers.

\section{Recommendations for Italy}

- Strengthen public investment in care services for children, disabled and elderly people. Stimulate private care service offerings and provide ad hoc tax reduction mechanisms, thereby facilitating women's entrepreneurship.

- Invest in women's financial and STEM education in order to equip them with the skills required to launch innovative, growth-oriented firms.

- Support the entrepreneurial ecosystem in ways that will benefit women entrepreneurs and attract private investors interested in financing Italian women-led firms.

\section{References}

AlmaLaurea (2018), “XX Survey (2018) - Graduates' Employment Conditions”, Rome, https://www.almalaurea.it/en/universita/occupazione/occupazione16.

Bettio, F. and J. Plantenga (2004), "Comparing care regimes in Europe", Feminist Economics, Vol. 10, No. 1, pp. 85-113.

Carta, F. (2019), "Female labour supply in Italy: the role of parental leave and child care policies", Questioni di Economia e Finanza (Occasional Papers), Printing and Publishing Division of the Bank of Italy, Rome. 
Censis (2019), "Donne: hanno il primato negli studi, altro che gender gap", https://www.censis.it/formazione/donne-hanno-il-primato-negli-studi-altro-che-gender-gap.

Eurostat (2020), "Employment rate of adults by sex, age groups, educational attainment level, number of children and age of youngest child", Database:

https://appsso.eurostat.ec.europa.eu/nui/show.do?dataset=lfst hheredch\&lang=en (accessed on 4 June 2020).

Eurostat (2019), "Employment and activity by sex and age - annual data", Database: https://appsso.eurostat.ec.europa.eu (accessed on 4 June 2020).

InGenere (2020), "Prima, durante e dopo il Covid: disuguaglianze in famiglia", https://www.ingenere.it/articoli/prima-durante-dopo-covid-disuguaglianze-famiglia.

Italian Equal Opportunities Department (2020), “Donne per un nuovo rinascimento”, Rome, Italy, http://www.pariopportunita.gov.it/wp-content/uploads/2020/05/DEF.pdf.

Lassébie, J., S. Sakha, T. Kozluk, C. Menon, S. Breschi and N. Johnstone (2019), "Levelling the playing field. Dissecting The Gender Gap In The Funding Of Start-Ups", OECD Science, Technology and Industry Policy Papers. June 2019 No. 73, OECD Publishing, Paris, available at https://www.oecdilibrary.org/science-and-technology/levelling-the-playing-field 7ddddd07-en.

León, M. and M. Migliavacca, (2013), "Italy and Spain: Still the case of familistic welfare models?", Population Review, Vol. 52, No. 1, Sociological Demography Press, USA, pp. 25-42.

Ministero dello Sviluppo Economico (2019), La policy del Governo a sostegno delle PMI innovative, Rome, https://www.mise.gov.it/images/stories/documenti/Scheda\%20di\%20sintesi\%20PMI\%20innovative\%2 007 2019.pdf.

OECD (2017), "G20/OECD INFE report on adult financial literacy in G20 countries", OECD Publishing, Paris, http://www.oecd.org/daf/fin/financialeducation/G20-OECD-INFE-report-adult-financial-literacyin-G20-countries.pdf.

OECD (2017), "Employment: Time spent in paid and unpaid work, by sex", OECD Publishing, Paris, https://stats.oecd.org/index.aspx?queryid=54757.

OECD (2016), "Women entrepreneurship Key findings: Italy", OECD Publishing, Paris, http://www.oecd.org/sdd/business-stats/EaG-Italy-Eng.pdf.

Poggesi, S., M. Mari and L. De Vita (2017), "Women entrepreneurs and work-family conflict: an analysis of the antecedents", International Entrepreneurship and Management Journal, Vol. 15, No. 2, pp. 431454.

Saraceno, C. (2016), "Varieties of familialism: Comparing four southern European and East Asian welfare regimes", Journal of European Social Policy, Vol. 26, No. 4, pp. 314-326.

Unesco (2017), "Cracking the code: girls' and women's education in science, technology, engineering and mathematics (STEM), https://unesdoc.unesco.org/ark:/48223/pf0000253479.

Unioncamere (2019), "Imprese femminili: quasi 6mila in più nel 20184 mila sono di donne straniere", Unioncamere Rome, Italy, http://www.unioncamere.gov.it/P42A4078C160S123/imprese-femminili-quasi-6mila-in-piu-nel-2018--4mila-sono-di-donne-straniere.htm.

World Economic Forum (2020), “The Global Gender Gap Report 2020”, Geneva, Switzerland, http://www3.weforum.org/docs/WEF GGGR 2020.pdf. 


\title{
Mexico
}

\author{
By Rosa Nelly Trevinyo-Rodriguez, Trevinyo-Rodriguez \& Asociados
}

\section{Background}

Entrepreneurship policy is relatively new in Mexico. The Entrepreneurial Development Plan, Mexico's first formal policy to support entrepreneurs was launched in 2001. It aimed to boost economic development, growth and social welfare, facilitate an entrepreneurial culture and "increase competitiveness among the companies of the country, particularly the micro, small, and medium size companies" (Derbez, 2001: 05). An initial step outlined in the plan was to make it easier to start a business by amending burdensome business regulations, with a second step designed to introduce support programmes such as incubators, accelerators, entrepreneurial education and loan guarantee programmes. In 2007, key target entrepreneurial segments were identified: nascent entrepreneurs, micro-enterprises, SMEs, "gazelles" (fast-growing SMEs) and tractor firms ${ }^{1}$ as well as salient services offered by public policies - financing, consultancy, management, commercialisation and innovation. In 2013, the National Entrepreneur's Institute (INADEM) was created as a decentralised government entity reporting directly to the Ministry of Economy. INADEM's main responsibilities included the design, implementation and coordination of national policies for entrepreneurs and SMEs. Established agencies such as Nacional Financiera (NAFIN) - a development bank managing Mexico's largest loan guarantee programme, and The National Council of Science and Technology (CONACYT) - an agency promoting scientific and technological activities, reinforced these policy efforts. Additionally, in 2018, amendments were made to the General Law of Commercial Companies (LGSM), and new laws ${ }^{2}$ were introduced. Yet, in 2019, legislators approved INADEM's dissolution ${ }^{3}$ with no replacement initiative in place, leaving a gap in the Mexican entrepreneurial ecosystem.

There is currently no dedicated policy for women's entrepreneurship in Mexico. However, the 2001 Entrepreneurial Development Plan aimed to "release the huge potential of [both] men and women" (Fox, 2001). To fulfil this goal, INADEM launched several large-scale programmes and funds explicitly targeted at women entrepreneurs between 2013 and 2018. These included Women Moving Mexico (Mujeres Moviendo México), which provided entrepreneurial training and advice to 42000 women microentrepreneurs through 7 centres; and SME Women (Mujer PYME) that financed 9622 companies led by women. In addition, INADEM launched a seed fund for high-impact, innovative and/or export-oriented firms, whereby women applicants received additional points in some proposal calls as an affirmative action measure aimed at closing the gender gap. INADEM also supported an annual national woman entrepreneur award, and collaborated with the National Institute of Women (INMUJERES ${ }^{4}$ ) to provide educational programmes to develop woman-led micro-businesses.

These efforts paid off. In 2014 , women owned $30 \%$ of microenterprises, $22 \%$ of small, $13 \%$ of medium and $7.8 \%$ of large firms formally registered in Mexico (INEGI, 2015a). Three years later, in 2017, numbers were quite different. At that point, women owned $28 \%$ of microenterprises, $24 \%$ of small firms, $13 \%$ of mediumsized companies and $9 \%$ of large businesses ${ }^{5}$ (INEGI, 2018). These data illustrate a transition of some micro-enterprises to small-firms, as well as the creation of new small businesses. The latter is consistent with a multiannual evaluation (2014-17) conducted by the World Bank of the Women Moving Mexico (Mujeres Moviendo México) programme which concluded that women micro-entrepreneurs participating in the training programmes acquired higher knowledge on business related concepts and adopted formal managerial practices that led them to increase their revenues and productivity, "which was accompanied by an expansion of their businesses" - growth in size (World Bank, 2017). Correspondingly, the NAFIN 2018 annual report indicates that credits and funds funnelled to support the SME Women programme (Mujer PYME) escalated between 2015 and 2018 - from 23 credits for the amount of MXN 18 million pesos in 2015, to 5782 credits for the amount of MXN 8444 billion pesos in 2018 (NAFIN, 2018). 
In spite of these initiatives, women-owned businesses are still typically smaller and use fewer financial services than men-owned firms (de Haan, 2016; World Bank, 2019). While there may well be several different reasons for this phenomenon, women's lack of financial literacy and financial inclusion play a role (Hung 2012; OECD, 2019).

\section{Policy issue: Financial literacy and financial exclusion}

In Mexico, parents and schools are the first and most important sources of financial literacy ${ }^{6}$ (INEGI, $2015 b)$, exerting a critical role in inhibiting or supporting women's financial learning. However, societal and cultural factors (i.e. attachment to traditional gender roles) continue to have an impact on women's levels of financial education, exposure and opportunities. Among a survey of 2022 Mexicans, men were found to be more likely than women to have been taught money management by their fathers (Reddy et al., 2013). With regard to school education, Mexican girls report a marked deficit in mathematical skills compared to Mexican boys ${ }^{7}$ and to the OECD average (OECD, 2019b). These gender gaps are particularly important as financial literacy depends on numeracy or arithmetic (Villagómez et al., 2017). This lack of mathematical abilities hampers women's business competence, and hence, the growth potential of their firms given that financially literate individuals do better at budgeting, saving money, controlling spending, contracting debt and long-term planning (Hung, 2012). While financial literacy is globally acknowledged as an essential life skill, and G20 leaders recognise that it requires lifelong learning that starts in childhood (OECD, 2019c), most Mexican girls and women are still lacking the financial knowledge to improve their well-being, social-mobility and economic future (World Bank, 2019).

Thus, despite a sharp increase in Mexico's financial infrastructure, financial exclusion for women is the highest amongst OECD countries (OECD, 2017). This may be due in part to their lower levels of financial literacy, which is needed to make full use of the available infrastructure, as well as to other context-specific barriers, such as: gender-biased loan allocations and credit scoring; lack of high-value assets ${ }^{8}$ and collateral; weaker credit histories, unfavourable lending policies ${ }^{9}$ and a higher cost of funding due to smaller loans, shorter repayment periods and higher interest rates (OECD/EU, 2018; Chin, 2017). Only 8\% of women in Mexico report having used a bank loan to fund their business compared to $16 \%$ of men (OECD, 2018). Needless to say, this lack of accessible, affordable funding limits the competitiveness of womenowned firms, preventing them from seizing business opportunities that could allow them to achieve scale (Fareed et al., 2017).

As an example, although becoming a corporate supplier catalyses growth while also increasing revenue, financial stability and market credibility, the potential of women-owned enterprises to participate in corporate procurement opportunities is limited (Chin, 2017). In Mexico, $27 \%$ of the country's workforce is composed of business owners, out of which $9.7 \%$ represent women entrepreneurs. Yet, from this $9.7 \%$ only $0.005 \%$ of the Mexican workforce is made up of women employing at least 50 workers (Lundy and Bowdish, 2014), which represent the type of small firms that corporations usually buy from ${ }^{10}$ (Chin, 2017). Given that most formally registered women-owned firms in the country are micro and small-sized (INEGI, 2018), ${ }^{11}$ and that they are financially underserved or unserved (Buckland et.al., 2019), women's financial exclusion coupled with other structural impediments such as limiting contract sizes to large quantities and requiring specific technical qualifications and capabilities in the area of technology, prevent women business owners from accessing and fully participating in the corporate supply chain. Moreover, corporations' financial requirements for suppliers, such as audited financial accounts, performance bonds, bid guarantees, insurance and fees for tender documents, are too onerous and time consuming, putting women-owned firms at a disadvantage with respect to bidding and compliance costs as well as in their ability to absorb the impact of delayed payments (Chin, 2017). The latter creates a self-perpetuating cycle, thus exacerbating negative effects in women's financial inclusion and in their firms' access to growth possibilities. 


\section{Conclusions and recommendations}

Key measures for addressing Mexican women's lack of financial literacy and financial exclusion could include incorporating financial education through the existing, mandatory, academic curriculum set by the National Ministry of Education (SEP) from pre-school to upper secondary education. ${ }^{12}$ This should be coupled with strengthening the quality of instruction in mathematics at all educational levels. At the same time, awareness raising measures should be introduced to encourage families equalise financial learning opportunities for both boys and girls. In addition, affirmative actions or gender quotas in credit approvals, grant/loan allocations and entrepreneurial support programmes could be instituted (and audited). Current financial policies might also consider promoting a women-specific preference approach in commercial banks' loan underwriting and pricing standards. In parallel, policies designed to support entrepreneurship in Mexico should consider developing women-owned firms' focused funds to financially support and train women business owners seeking access to corporate supply chains.

In summary, in spite of substantial developments in Mexico's entrepreneurial ecosystem since 2001, more needs to be done to advance women's entrepreneurship. Since INADEM's dissolution in June 2019, the query remains as to whether the current government will build up the existing entrepreneurial ecosystem, especially when it comes to growing women-owned firms, and if so, through what combination of policy initiatives.

\section{Recommendations for Mexico}

- Incorporate financial education throughout the existing, mandatory, academic curriculum.

- Establish affirmative action procedures or gender quotas in loan/grant allocations, credit approval processes and entrepreneurial support programmes. Promote a women-specific preference approach in commercial banks' loan underwriting and pricing standards.

- Develop women-focused funds to support and train women business owners who are seeking to access corporate supply chains.

\section{References}

Buckland, L., M. Cordobes, S.O. Cruz and L. Murphy (2019), Gender Lens Investing: How Finance Can Accelerate Gender Equality in Latin America and the Caribbean, Inter-American Development Bank (IDB Invest), Washington, DC, https://idbinvest.org/en/publications/report-gender-lens-investing-howfinance-can-accelerate-gender-equality-latin-america.

Chin, K. (2017), The Power of Procurement: How to Source from Women-Owned Businesses, UN Women, New York, https://www.unwomen.org//media/headquarters/attachments/sections/library/publications/2017/the-power-of-procurement-howto-source-from-women-owned-businesses-en.pdf?la=en\&vs=237.

de Haan, A. (2016), Enhancing the Productivity of Women-Owned Enterprises: The Evidence on What Works and a Research Agenda, Growth and Economic Opportunities for Wokmen (GrOW), Ottawa, http://hdl.handle.net/10625/55635.

Derbez, L. (2001), "Message from the Secretary of Economy", in Entrepreneurial Development Plan 2001-2006, Secretary of Economy (SE), Mexico, http://www.economiasnci.gob.mx/sic php/pages/files varios/pdfs/entrepreneurial development.pdf.

Fareed, F., M. Gabriel, P. Lenain and J. Reynaud, (2017), "Financial Inclusion and Women Entrepreneurship: Evidence from Mexico", OECD Economics Department Working Papers, No. 1411, OECD Publishing, Paris, https://doi.org/10.1787/2fbd0f35-en. 
Fox, V. (2001), "Message from the President of Mexico: Presentation of the Program for the Entrepreneurial Development", in Entrepreneurial Development Plan 2001-2006, Secretary of Economy (SE), Mexico, http://www.economiasnci.gob.mx/sic php/pages/files varios/pdfs/entrepreneurial development.pdf.

Hung, A., J. Yoong and E. Brown (2012), "Empowering Women Through Financial Awareness and Education", OECD Working Papers on Finance, Insurance and Private Pensions, No. 14, OECD Publishing, Paris, https://doi.org/10.1787/5k9d5v6kh56g-en.

INEGI (2015a), Encuesta Nacional de Financiamiento de las Empresas-ENAFIN 2015 (National Survey of Enterprise Financing 2015), National Institute of Statistics and Geography, Mexico, https://en.www.inegi.org.mx/programas/enafin/2015/.

INEGI (2015b), Encuesta Nacional de Inclusión Financiera-ENIF 2015 (National Survey for Financial Inclusion 2015), National Institute of Statistics and Geography, Mexico, https://www.afiglobal.org/sites/default/files/blogentry/Cuadr\%C3\%ADptico\%202016\%20\%28inglés\%29.pdf.

INEGI (2018), Encuesta Nacional de Financiamiento de las Empresas-ENAFIN 2018 (National Survey of Enterprise Financing 2018), National Institute of Statistics and Geography, Mexico, https://www.gob.mx/cms/uploads/attachment/file/498792/REPORTE ENAFIN2018.pdf.

Lundy, J. and L. Bowdish (2014), From Millions to Billions: Scaling up Women's Empowerment Globally, US Chamber of Commerce Foundation, Corporate Citizenship Center, Washington, DC, https://www.uschamberfoundation.org/millions-billions-scaling-womens-empowerment-globally.

NAFIN (2018), Annual Report (English), Nacional Financiera, Mexico, https://www.nafin.com/portalnf/files/secciones/normatividad/pdf/informes anuales/2018/Informe anua 2018 INGLES.pdf.

OECD (2019a), "Key policy insights", in OECD Economic Surveys: Mexico 2019, OECD Publishing, Paris, https://doi.org/10.1787/c02d529b-en.

OECD (2019b), Mexico Country Note-PISA 2018 Results (Volumes I-III), PISA, OECD Publishing, Paris, http://www.oecd.org/pisa/publications/PISA2018 CN MEX.pdf.

OECD (2019c), "PISA 2018 Financial Literacy Framework", in PISA 2018 Assessment and Analytical Framework, OECD Publishing, Paris, https://doi.org/10.1787/a1fad77c-en.

OECD (2018), Entrepreneurship at a Glance 2018-Highlights, OECD Publishing, Paris, https://www.oecd.org/sdd/business-stats/EAG-2018-Highlights.pdf.

OECD (2017a), OECD Economic Surveys: Mexico 2017, OECD Publishing, Paris, https://doi.org/10.1787/eco surveys-mex-2017-en.

OECD (2017b), "General government expenditures", in Government at a Glance 2017, OECD Publishing, Paris, https://doi.org/10.1787/gov glance-2017-17-en.

OECD/EU (2018), "Policy Brief on Women's Entrepreneurship", OECD SME and Entrepreneurship Papers, No. 8, OECD Publishing, Paris, https://doi.org/10.1787/dd2d79e7-en.

Reddy, R., M. Bruhn and C. Tan (2013), Financial Capability in Mexico: Results from a National Survey on Financial Behaviours, Attitudes, and Knowledge, World Bank, Washington, DC, http://documents.worldbank.org/curated/en/653031468287158989/Financial-capability-in-Mexicoresults-from-a-national-survey-on-financial-behaviors-attitudes-and-knowledge.

Villagomez-Amezcua, A. and J. A. Hidalgo Everardo (2017), "Financial Literacy and Mathematics: A Study Among Young Mexican High School Students", Revista Mexicana de Economía y Finanzas (The Mexican Journal of Economics and Finance), Vol.12, No. 2, Instituto Mexicano de Ejecutivos de Finanzas (IMEF), pp.1-22, ISSN 2448-6795, http://www.scielo.org.mx/pdf/rmef/v12n2/2448-6795rmef-12-02-00001.pdf.

World Bank (2019), Mexico Gender Assessment, World Bank, Washington, DC, http://documents.worldbank.org/curated/en/377311556867098027/pdf/Mexico-Gender- 
Assessment.pdf.

World Bank (2017), "Female Entrepreneurship in Mexico: Impact Evaluation of a Large-Scale Program to Promote Female Micro-Entrepreneurs.", in Report on Mid-Term Results, Report No. AUS9542, World Bank, Washington, DC, http://crea.org.mx/wp-content/uploads/2017/03/World-Bank.-2017-Impactevaluation-CREA.pdf.

\section{Notes}

${ }^{1}$ Companies with the potential to lead a production chain.

${ }^{2}$ For example, the Entrepreneur's Law, the Fintech Law, and the Re-entrepreneurship Law.

3 In 2018, allegations of corruption at INADEM became public. As a result, INADEM's budget was substantially reduced, and in June 2019, legislators approved its dissolution.

${ }^{4}$ Created in 2001, INMUJERES' main objective is to promote and foster conditions to enable women equal participation in the political, cultural, economic and social life of the country. INMUJERES has targeted several programmes at women business owners, including: Micro-Financing of Rural Women and the National Fund for Support of Solidarity Enterprises.

${ }^{5}$ It's important to note that, in 2016, a succession tax bill was proposed by a legislator and analyzed by the Mexican Chamber of Deputies. Although it was not approved, it might have prompted transfers of wealth (i.e. enterprises) from parents to children.

${ }^{6}$ The OECD/INFE definition of financial literacy is: "a combination of awareness, knowledge, skill, attitude and behaviour necessary to make sound financial decisions and ultimately achieve individual financial wellbeing."

7 The PISA 2018 results show that boys outperformed girls in mathematics by 12 score points. Yet, across OECD countries, on average, boys outperformed girls in mathematics by just five score points.

8 In 2018, 65\% of women in Mexico did not own a high-value asset (World Bank, 2019).

${ }^{9}$ Evidence pinpoints tighter borrowing requirements for women.

10 These firms have proven track records and can provide goods and services in large quantities and at lower prices.

11 Microenterprise: From 0 to 10 employees; small-size company: from 11 to 50 employees; medium-size firm: from 51 employees up to 250 employees.

12 Education free of charge and compulsory for all Mexican students starts in pre-school (ages: 3 to 6 ) and ends in grade 12 (upper secondary education). 
By Lene Foss, UiT - The Arctic University of Norway and Jönköping University, Sweden

\section{Background}

Among others, public policy and access to financial capital are key elements of entrepreneurial ecosystems (Hechavarria and Ingram, 2014). Similarly, gender equality is an important determinant of entrepreneurial activity (Griffiths, Gundry and Kickul, 2013). In Norway, women are under-represented among entrepreneurs and business owners despite an increased policy focus on supporting women's entrepreneurship in recent years.

\section{Policy issue: Access to finance}

The Royal Ministry of Children, Equality and Social Inclusion (2015-16) reports that one in four entrepreneurs are women; that men have greater access to capital than women - making it easier to start a business; and that there are fewer women than men entrepreneurs, executives and directors. In 2013, women comprised $37 \%$ of those establishing sole proprietorships, general partnerships (ANS) or general partnerships with shared liability (DA). Among those who established a limited company (AS) or public limited company (ASA), women accounted for only $20 \%$. Sectors with the highest proportion of women entrepreneurs are health and social services, education, accommodation and food services.

There are several types of financing available to entrepreneurs in Norway, ranging from industrial development funds, private funds, bank loans, crowdsourcing and investors. Among the sources of public funding, the best known is Innovation Norway, which is listed as the government's most important instrument for innovation and development. Innovation Norway manages public sector efforts to support entrepreneurship and has a strong focus on supporting women in business (Regjeringen, 2015-16). The ministry's goal is that at least $40 \%$ of business-targeted funds reach women, but in 2014 only $35 \%$ of funds did so. However, in the three years prior to 2014, the proportion of business-targeted funds that reached women was around $40 \%$.

\section{Measures to promote better access to financial capital for women 2015}

Gender differences in access to financial capital are viewed as an impediment to both enterprise growth and job creation. Economic agencies, industry associations, advocates and scholars have called for the provision of inclusive financing policies to strengthen entrepreneurial ecosystems as a means for addressing the perceived gaps between policy and practice (Brush et al., 2018).

In the national budget for 2015, Norwegian policy identified 17 measures to improve access to financial capital for entrepreneurs (Norwegian Ministry of Trade, Industry and Fisheries, 2016). While none of these measures is targeted directly at women, it was recommended that funding agencies pay greater attention to women entrepreneurs. The 17 measures are divided into two groups: six measures deal with strengthening the public supply of capital in the early start-up phase, and 11 deal with remedying entrepreneurs' funding problems during the early start-up phase.

The government strengthened the public supply of early phase financial capital through the following six measures:

1. The nationwide start-up grant scheme of Innovation Norway was strengthened with an additional NOK 110 million (approximately EUR 10.1 million).

2. An additional NOK 100 million (approximately EUR 9.2 million) was proposed to Innovation Norway for entrepreneurship and restructuring measures to address challenges in the oil and gas industry. 
3. Two new, national seed capital funds were established, each was allocated NOK 300 million (approximately EUR 27 million).

4. Investinor was allocated NOK 100 million (approximately EUR 9.2 million) to invest in small, scalable businesses.

5. Capital tax rates were reduced directly, as well as through an increase in basic deductions.

6. NOK 40 million (approximately EUR 3.7 million) was allocated to grants for pre-seed funds.

In order to address entrepreneurs' funding problems in the early phase of their business, the Norwegian government implemented the following eleven measures:

1. Strengthened the pre-seed funding scheme in 2016 by NOK 100 million (approximately EUR 9.2 million), which is a measure intended to release private investment capital to young, innovative businesses located in an innovative environment.

2. Gradually established additional seed funds so that all regions are covered.

3. Strengthened the start-up scheme to NOK 350 million (approximately EUR 32.5 million) to promote growing businesses, and potentially increase funding for businesses by matching these funds with capital from private investors.

4. Strengthened the Skattefunn scheme, which provides the opportunity for small and medium-sized businesses to allow $20 \%$ of their project costs as a tax reduction.

5. Strengthened the environmental technology scheme to a total of NOK 464.5 million (approximately EUR 42.7 million).

6. Strengthened the User-driven Research based Innovation programme. This deals with innovation projects, with a high degree of R\&D activities led by the industry itself. Each project has to contribute substantially to renewal and increased value creation for the firms participating in the project and for the industry in general, in that new knowledge and solutions are made available.

7. Commissioned Innovation Norway to facilitate networks for business angels in order to strengthen their competence and investment ability.

8. Increased monitoring of EU efforts in the area of crowdfunding.

9. Committed to examining further reductions in the capital tax rate in future budgets.

10. Committed to examine a range of measures to strengthen the incentives for employee coownership, including shares and options for employees.

11. Reduced the delay between the approval and disbursement of grants from Innovation Norway faster.

While many steps have been taken to improve access to funds for women entrepreneurs, the vast majority of funds are delivered through gender neutral mainstream programmes. ${ }^{1}$ Furthermore, due to structural industrial adjustments (new industries are needed to replace oil and gas), the Norwegian government also seeks to increase access to business skills for entrepreneurs, notably by improving access to business advice and networks, further embedding entrepreneurship into the education system, strengthening support for the commercialisation of research, and improving the protection of intangible assets (Norwegian Ministry of Trade, Industry and Fisheries, 2016). Spillover effects between these actions are expected, making financial capital for women innovative entrepreneurs more readily available. Hence, there could be specific funding opportunities for women-led enterprises that seek to meet society's "grand challenges", including the ageing of the population, reducing carbon emissions and digitalisation.

\section{Status for access to financial capital for women 2019}

In the new action plan for women entrepreneurs from The Norwegian Ministry of Trade, Industry and Fisheries and The Norwegian Ministry of Culture (2019) neither the 17 measures from 2015 nor the results 
of those policies are mentioned. Consequently, it is hard to know the effect of the financial policies. In the section titled "Women have less access to capital" the plan refers to research on the effects of entrepreneurs' own savings on the success of growth companies. In Norway savings have a stronger effect on men's propensity to start a business compared to women (Berglann et al., 2011). Attracting investors is another important issue for women entrepreneurs, as research shows that women face larger problems than men in attracting investment capital (Alsos et al., 2006). The action plan mentions several reasons (p. 21): Women start businesses in industries with lower growth rates, which hampers the possibility of gaining access to capital. Another issue is that investors may choose to invest in entrepreneurs who are like them (gender, education and background). As both education and work experience in Norway are gendered, this may lead to male investors investing in male entrepreneurs. Finally, the action plan refers to an OECD report, which reveals that businesses with at least one woman receive significantly less capital than entrepreneurial teams with men only (Lassebie and Sakha, 2019). A study of women's entrepreneurship (Grünfeld et al., 2019) concludes that Norway faces large and continuous differences between women's and men's entrepreneurship. Although there has been a small increase in the share of women entrepreneurs through the last 20 years, women's gains have been slow. Further, women's participation in entrepreneurship decreases with greater focus on growth, technology, scalability and financial risk. Thus, policies for greater access to capital for women entrepreneurs are needed to address the underrepresentation of women among entrepreneurs and innovators with considerable societal impact, i.e. employment, new innovations and social enterprises.

The action plan concludes with 12 measures (Norwegian Ministry of Trade, Industry and Fisheries and Norwegian Ministry of Culture, 2019):

- Measure 1: The government will map out how the instruments are distributed by gender and establish common standards so that the government can have an overview of how much support goes to women entrepreneurs.

- Measure 2: The government will get better statistics on start-ups, including a better overview of how start-ups are distributed by gender.

- Measure 3: The government will fund the Global Entrepreneurship Monitor for 2019.

- Measure 4: The government will consider whether other criteria can be used in addition to age for instruments that support young businesses.

- Measure 5: The government will present a report to the Storting on innovation in the public sector.

- Measure 6: The government will map entrepreneurship education and the need to possibly strengthen this within the health professional educations.

- Measure 7: The government will follow up on the White Paper on the Health Industries.

- Measure 8: Prioritise sectors and access to the public market.

- Measure 9: The government will consider measures that mobilise more growth-oriented women entrepreneurs

- Measure 10: Tax rules

- Measure 11: Sole proprietorships

- Measure 12: Social rights for the self-employed.

The government also decided to address the "policy instrument jungle" that exists for Norway's business sector. Today there are 180 different arrangements which are administered by 14 different Ministries and 18 different national units. It is quite expensive for entrepreneurs to find the correct funding scheme they should apply to. Two out of five entrepreneurs need assistance to apply, and one in five pay for this assistance. The government aims for a new digital portal to be completed by the end of 2020 . 


\section{Conclusion and recommendations}

The public policy for access to financial capital for entrepreneurs in Norway has intended to increase the availability for funding. Several measures were provided in the national budget of 2015- 2016, but none was specifically targeted towards women. An evaluation of these measures from the governmental plan was not published, and the government acknowledges that the statistics for women entrepreneurs are not satisfactory. Thus, one of the new measures in the 2019 plan is to enhance the statistics on women's entrepreneurship. The government's new action plan for 2019 has a stronger gender-oriented focus on financial capital, as policy makers recognise that women's entrepreneurship has increased only slightly in the last 20 years. In response, more measures to provide easier access to financial capital for women are now being taken.

\section{Recommendations for Norway}

- Evaluate government policy measures for increasing women entrepreneurs' access to financial capital.

- Introduce more detailed follow up of women entrepreneurs' experiences with the new digital portal for 2020.

- Increase funding for women's entrepreneurship growth in technology ventures, in enterprises with high scalability and those with financial risk.

\section{References}

Alsos, G. A., E. J. Isaksen and E. Ljunggren (2006), "New venture financing and subsequent business growth in men-and women-led businesses", Entrepreneurship Theory and Practice https://journals.sagepub.com/doi/10.1111/j.1540-6520.2006.00141.x.

Bell, A., R. Chetty, X. Jaravel, N. Petkova and J. Van Reenen (2018), "Who Becomes an Inventor in America? The Importance of exposure to Innovation", The Quarterly Journal of Economics, Vol.134, No. 2, pp. 647-713, https://doi.org/10.1093/qje/qiy028.

Berglann, H., E. R. Moen, K. Röed and J. F. Skogström (2011), "Entrepreneurship origins and returns", Labour Economics, Vol. 18, pp. 180-193.

https://www.sciencedirect.com/science/article/pii/S0927537110001041?via\%3Dihub.

Brush, C., L. F. Edelman, T. Manolova and F. Welter (2018), "A gendered look at entrepreneurship ecosystems", Small Business Economics, Vol. pp. 1-16, https://link.springer.com/content/pdf/10.1007/s11187-018-9992-9.pdf.

Områdegjennomgang av det näringsrettede virkemiddelapparatet. Helhetlig anbefaling om innretning og organisering av det näringsrettede virkemiddelapparatet (2019), "Review of the business-oriented policy instruments: Comprehensive recommendation on the design and organization of the businessoriented policy instruments", Delloitte,

https://www.regjeringen.no/contentassets/0f8355831ed346c38fba23362eaa59be/helhetlig-anbefalingom-innretning-og-organisering-av-det-naringsrettede-virkemiddelapparatet.pdf.

Griffiths, M., L. Gundry and J.Kickul (2013), "The socio-political, economic, and cultural determinants of social entrepreneurship activity”, Journal of Small Business and Enterprise Development, Vol. 20,

No. 2, pp. 341-357, https://www.emerald.com/insight/content/doi/10.1108/14626001311326761/full/html.

Grünfeld, L., S. Hernes, V. Idland, H. Hvide and E. Olssön (2019), "Kvinnelig entreprenörskap i Norge: Utviklingstrekk, hindre og muligheter", Menon Economics, Rapport no. 1, 2019. https://www.menon.no/wp-content/uploads/2019-01-Kvinnelig-entrepren\%C3\%B8rskap-i-Norge.pdf. 
Hechavarria, D. M and A. Ingram (2014), "A review of the entrepreneurial ecosystem and the entrepreneurial society in the United States: An exploration with the Global Entrepreneurship Monitor dataset", Journal of Business \& Entrepreneurship, Vol 26-1.

https://www.researchgate.net/profile/Thomas Pittz/publication/268510441 A Model for Experiential Entrepreneurship Education/links/54be890a0cf28ce312326bad/A-Model-for-ExperientialEntrepreneurship-Education.pdf\#page=10.

Norwegian Ministry of Trade, Industry and Fisheries (2016), "Good ideas - future jobs The Government Entrepreneurship Plan", https://www.regjeringen.no/contentassets/c639c03e8fd94ceea1f9fc9318449ca4/the government entr epreneurship plan.pdf.

Lassebie, J. and S. Sakha (2019), Levelling the playing field: Dissecting the gender gap in the Funding of Innovative Start-Ups using Crunchbase, OECD,

https://www.oecd.org/officialdocuments/publicdisplaydocumentpdf/?cote=DSTI/CIIE(2019)3/FINAL\&d ocLanguage $=$ En.

Norwegian Ministry of Trade, Industry and Fisheries and Norwegian Ministry of Culture (2019), "Action plan for female entrepreneurs", https://www.regjeringen.no/globalassets/departementene/nfd/dokumenter/vedlegg/192578handlingsplan-uu.pdf.

OECD/EU (2018) (2018), “Policy Brief on Women's Entrepreneurship”, OECD SME and Entrepreneurship Papers, No. 8, OECD Publishing, Paris, https://doi.org/10.1787/dd2d79e7-en.

Statistisk Sentralbyrå (SSB) (2018), Fakta om likestilling (Facts about gender equality), https://www.ssb.no/befolkning/faktaside/likestilling.

The Royal Ministry of Children, Equality and Social Inclusion (2015-2016), "White Paper Meld. St. 7. Report to the Storting. Gender equality in practice - equal opportunities for women and men", https://www.regieringen.no/contentassets/cb13bb1a651942b9ae61d329e85c2c7e/gender-equality-inpractice---white-paper.pdf.

\section{Note}

1 This situation is not unusual, and is similar to other countries, such as Finland, Germany and Austria, where women face fewer challenges in accessing education and labour market opportunities (cf. OECD/EU, 2018; pp. 28). 


\section{South Africa}

By Bridget Irene, Coventry University

\section{Background}

The South African Department of Trade and Industry's (DTI) policy on gender equality seeks to address barriers to women's entrepreneurship by promoting social and economic integration. The policy recognises that inclusion and gender equality are integral to economic development and are required to increase women's self-confidence, self-reliance, and help women set their own business agenda. To this end, in 2006, DTI created the Gender and Women's Empowerment Unit (GWE) with the mandate to advance gender equity at the national and international level (DTI, 2006). The Department of Trade and Industry, in partnership with the ILO, also revised the Draft Strategic Framework on Gender and Women's Economic Empowerment to provide guidance and to advance specific recommendations for the support required to assure the full involvement of women in the South African economy.

In 2013, the Women's Empowerment and Gender Equality Bill (WEGE) was introduced to the National Assembly by the Ministry of Women, Children, Youth and People with Disabilities (MWCYPD) in order to fast track promotion of gender equality. It was the second national initiative to address the disempowerment and systematic inequality of women. The Bill addressed pervasive discriminatory patriarchal attitudes and lingering effects of the apartheid system that were considered as barriers to women. The Bill also dealt with the "social development" of women, via education and training aimed at eradicating gender-based discrimination and violence and increasing education around access to healthcare, as well as equal representation. Studies show that Black and Coloured women are more likely to experience discrimination and have fewer opportunities than other demographic groups, including Indians and Whites. This applies to a range of women including migrants, refugees, women with disabilities and women in rural areas. These women are increasingly disenfranchised and unable to access financial services or business support opportunities. In principle, the Bill compels "designated bodies" - including big businesses and corporate entities - to extend broad and equal participation of women in the economic mainstream (e.g. $50 \%$ of board level or decision-making positions are to be held by women). The "designated bodies" were also tasked with (a) "increasing access to financing, procurement, land rights, skills development, especially entrepreneurial skills and capacity building of women; and (b) facilitate employment opportunities and access to the markets for women.

WEGE has provoked fierce and almost universal criticism from women's rights organisations. Most considered the legislation to be vague and lacking details about the forms and methods that the "designated bodies" must take for the implementation of the bill, the selection process for "designated bodies," or the capacity of the relevant departments within the ministry to undertake such a broad scale project. The Bill was passed in February 2014 after several amendments that addressed some of these criticisms.

\section{Policy issue: Access to finance}

In 2006, the government initiated the Broad-Based Black Economic Empowerment Act (BBBEE) with the mandate to increase "the extent to which Black women own and manage existing and new enterprises, and increasing their access to economic activities, infrastructure, and skills training" (DTI, 2006). The Act seeks to address historical exclusion of Black people from the mainstream economy and to promote social cohesion across communities. The Act stipulates that: "in order to comply with the equality provision of the constitution, a code of good practice and targets therein specified may distinguish between black men and black women" (Para 9.4.). Notwithstanding the provisions in the BBBEE Act, the Financial Sector Charter (2003) specifies gender targets in staffing which are extremely low. Gender equality in enterprise development or procurement of finance are not addressed. 
The Codes of Good Practice was introduced in 2005. These state that preferential public procurement and enterprise development cannot distinguish between Black men and Black women, despite provisions made in the BBBEE Act that underpin the requirement for compliance with the equality provision of the constitution. As a result, most financial institutions assume that women are automatic beneficiaries of the BBBEE strategy and do not require further assistance. Consequently, the marginalisation of Black women will continue until interventions are implemented to correct this situation. Clarifications notes were issued in the Government Gazette 3899 in 2015, yet the gap between reality and intention remains in terms of transformation. The Preferential Procurement Code was included to promote economic empowerment and create a platform to encourage participation and narrow the gaps inherent in the previous guidelines. Particularly, regulations were designed to reduce "fronting" by large organisations that include Black people (men and women) for the sole purpose of achieving the empowerment status requirement. However, the code emphasised "Black" thus, women, youth and the disabled were summed up as a subset of race. Consequently, gender has been lost in the predominantly male (regardless of race) business environment, thereby undermining the intended "meaningful participation" of women touted in the BBBEE Act. Until now, the codes do not align with the original BEE Act in terms of distinguishing between Black men and women (Para 9.4, stated earlier).

Complementary barriers to women entrepreneurs in South African policy include a lack of entrepreneurship training and small business supports. Notwithstanding a 1995 White paper ${ }^{1}$ (1995:33) that emphasised the need for women-focused small business training, public business development services do not adequately integrate initiatives to increase women's access to finance. This is important given that many women entrepreneurs lack collateral, particularly Black women entrepreneurs. To mitigate risk and improve the likelihood of accessing and repaying loans, women entrepreneurs need business supports in the form of training, advice and mentoring.

\section{Conclusions and recommendations}

While the policy framework in South Africa is progressive, there are no targets for women in business set out in the codes. Charged with the implementation of the government's national strategy to support women entrepreneurs, The South African Department of Trade and Industry (DTI) has created the Centre for Small Business Promotion (CSBP). The purpose of the CSBP is to implement the 1995 White Paper recommendations. The focus is to provide a platform for all levels of government (national, provincial and local) to align policies and support measures for the growth and development of SMMEs, especially businesses owned by women or Previously Disadvantaged Individuals (PIDs). Due to legislative ambiguities, the mandate of the BBBEE Act - which seeks to address issues such as facilitating access to capital for women entrepreneurs - has not been achieved. Based on the experiences of women entrepreneurs in South Africa, the following recommendations are offered. 


\section{Recommendations for South Africa}

- Review the BBBEE Act Codes and Industry Charters to distinguish Black men and Black women with respect to targets for women-owned business in terms of the Preferential Procurement Codes.

- Monitor and evaluate mechanisms to ensure that the Codes and Industry Charters significantly impact women's empowerment and remove barriers in business and financial environments, such as the cash guarantees required by vendors against non-performance. These negatively impact women in Preferential Procurement scenarios.

- The Department of Trade and Industry could publish a directory of financiers, including contact details, products and qualifying criteria, that is updated a regular basis and made widely available for use by women entrepreneurs.

- Encourage collaborations between financial institutions and procurement authorities to create an integrated system that emphasises skills transfer for both parties.

\section{References}

DTI - Department of Trade and Industry (1995), "White Paper on National Strategy for the Development and Promotion of Small Business in South Africa", Pretoria: Government Printer.

DTI - Department of Trade and Industry (1995), B-BBEE Charter, http://www.dti.gov.za/economic empowerment/bee.jsp (accessed on 26 March 2019).

Gender Stats SA (2011), "Gender Statistics in South Africa", http://www.statssa.gov.za/publications/Report-03-10-05/Report-03-10-052011.pdf (accessed on 26 March 2019).

Olivia Bliss (2014), "The Women Empowerment and Gender Equality Bill: Can It Live Up to Its Name?" (Oxford Human Rights Hub Blog), http://humanrights.dev3.oneltd.eu/?p=4677 (accessed on 24 June 2020).

\section{Note}

1 The White Paper on Small Business (1995) provides the framework for encouraging the growth and sustainability of small businesses as well as encouraging more enterprise development in disadvantaged communities and under-represented groups. 


\section{Spain}

By Maria Cristina Diaz Garcia, University of Castilla-La Mancha

\section{Background}

Historically, Spain has been characterised as having a smaller gender gap in entrepreneurial activity compared to most European Union Member States. In 2018, Spain ranked $25^{\text {th }}$ out of 54 countries in the ratio of female to male "Total early-stage Entrepreneurial Activity" (TEA) (Global Entrepreneurship Monitor, 2019). ${ }^{1}$ Women account for one-quarter (24.5\%) of own-account workers (OECD, 2017).

The recent economic crisis in Spain has resulted in cuts to women-focused small business support programmes and a backsliding in progress towards gender equality. In 2018, The Global Gender Gap Report downgraded Spain from 11th place in 2006 to 29 out of 148 countries. Women's "economic participation and opportunity" ranked 80 out of 149 countries (World Economic Forum, 2018).

Consistent with other economies, a key barrier that entrepreneurs face is access to finance (OECD, 2017). Securing capital without guarantees remains problematic, particularly during start-up and among low-tech businesses. It is especially difficult for entrepreneurs who seek loans of between EUR 10000 and EUR 50 000. Individuals who are most likely to experience this difficulty, yet have the capacity to manage the debt, are moderate income earners. To address these capital market gaps, microcredit programmes provide small amounts of capital to start or expand a microenterprise, contributing to wealth and job creation.

Spanish state-controlled agencies support a number of capital market interventions. The Institute of Official Credit (Instituto de Crédito Oficial, ICO) is a public bank that facilitates access to capital through intermediation of credit institutions. The Spanish Refinancing Company (Compañía Española de Reafianzamiento, CERSA) is a public refinancing company that shares the risk of small business loans (OECD, 2005). Founded in 1977 and under the Ministry of Science and Innovation, the Centre for the Development of Industrial Technology (Centro para el Desarrollo Tecnológico Industrial, CDTI) advances support to "increase the competitive edge of Spanish companies by raising their technological level" (CDTI, 2008). The National Innovation Company (Empresa Nacional de Innovación, ENISA) offers financial assistance to entrepreneurs who seek to expand their companies. Programmes are offered without consideration of gender in programme design. None of these programmes explicitly seek to foster women's entrepreneurship.

Observing a market gap, in 2000, The Women's Institute launched the Women's Entrepreneurship Support Programme (Programa de Apoyo Empresarial a las Mujeres, PAEM). The national programme is targeted at "entrepreneurs who want to start their business, and businesswomen with a business of less than five years old." The programme is promoted by the Women's Institute and Spanish Chamber of Commerce, with co-financing from the European Social Fund. The programme supports advisory services through Chambers of Commerce, an online portal (www.e-empresarias.net), microcredit without guarantees, and follow-on services of six months (a longer period of support was provided previously, however, this was reduced due to programme funding cuts). A collaboration agreement between The Women's Institute's PAEM programme and Microbank provides "microcredits for businesses in agreement with banking entities" (banking entities previously referred to these products as "social microcredits" and differentiating them from "financial microcredits"). Credit worthiness is determined through business plans that are assessed by intermediaries authorised by Microbank-La Caixa and the Secretary of State for Social Services and Equality. Microbank represents a new model of sustainable "social banking." The programme offers "social microcredits" targeted at the self-employed who have difficulty accessing traditional credit but retain enough human capital to create and manage a firm. The majority (78\%) of social micro-credit beneficiaries are women (Cordobés, Iglesias and Sanz, 2010). 
In 2019, PAEM provided funding support to 207 microcredit organisations (EUR 3.7 million) contributing to the creation of 2200 women-owned businesses and 2341 working places. Microbank-La Caixa offers micro-loans without collateral or a guarantee for a maximum of EUR 25 000. Funding covers up to 100\% of the project at a fixed interest rate of $5.9 \%$. Similar support services have been offered to firms with a shortage of cash due to the COVID-19 pandemic in which this rate is reduced to $3.9 \%$. Repayment is up to 6 years with a 6-month grace period. Assessment incudes a business plan and an online questionnaire to determine trustworthiness of loan-takers.

In addition, since 2014 the Women's Institute has supported a programme with CERSA to facilitate access to start-up finance, marketing/promotion, consolidation, growth and improvement of women entrepreneurs' business projects which have initiated their activity within the last three years. The Institute credits the costs of assessing the business projects in return for an endorsement (around EUR 800) allowing women entrepreneurs to obtain funding from mutual guarantee companies throughout the national territory. In 2018, 212 transactions were closed totalling EUR 17.7 million (in 2017, there were 253 transactions amounting to EUR 15.4 million). From 2005 to 2007, one of these mutual guarantee companies, the Reciprocal Guarantee Society at the Autonomous Community of Madrid (AVALMADRID, SGR), supported a department to foster women's entrepreneurship (De la Fuente et al., 2014).

Studies suggest that one factor restricting women's entrepreneurship is perceived difficulties in accessing external funding due to issues such as lack of trust and lack of support for women entrepreneurs (Sena, Scott and Roper, 2012). It can be assumed that having a gender approach within funding programmes will help to foster women's entrepreneurship. In this line of argument, De la Fuente et al. (2014) have reported that during the period in which AVALMADRID SGR had a Women's Department, there was an increase in the number of projects and the amount financed for women's entrepreneurs. That is, specific or targeted women-focused support had a positive impact on increasing women's entrepreneurship.

In sum, with the exception of two women-focused business support policies, a gender perspective is absent. For example, in 2013 the Law of Entrepreneurs and their Internationalisation was enacted with the mandate to support entrepreneurs and entrepreneurship, favouring development, growth and internationalisation. However, the gender perspective was neglected, and consequently, the opportunity to offer targeted support to women's entrepreneurship was lost (Ruiz Garijo, 2015).

\section{Policy issue: Access to finance}

There is room for improvement in policies to support entrepreneurship. The most urgent need is to increase access to financing. There are several institutions that advance funding and provide loan guarantee schemes to small businesses (ICO, CERSA, CDTI, ENISA). Others agencies, such as INJUVE and the Women's Institute, provide support for entrepreneurs as a complementary goal. This multi-institutional approach results in limited coordination in the implementation of policies to support women entrepreneurs. Within mainstream programmes there are no specific departments or strategic goals related to gender equality. This negates women entrepreneurs' needs.

Accordingly, Ortega (2012) states that actions of public administration in Spain are hampered by the lack of strategic and transversal approaches, limited co-ordination among agents associated with programme implementation, neglect of individual barriers to business start-up, and ineffective institutional changes. In 2018, Spain lagged behind other governments' entrepreneurship policies regarding "support and relevance" and "taxes and bureacracy" ( $39^{\text {th }}$ and $46^{\text {th }}$ of 54 countries surveyed) (GEM, 2019). With respect to inclusive entrepreneurship policies, the OECD reports (2018):

"Overall, despite advances in entrepreneurship policies, the inclusive entrepreneurship institutional support framework has been largely developed on an ad hoc basis. The main objectives of most of the institutions are not directly related to entrepreneurship, which is only incorporated as a complementary goal. This is the case, 
for instance, of the Young Persons' Institute (Instituto de la Juventud, INJUVE) and the Women Institute. Similarly, the public financial institution ICO has several funding programmes, and only one of them (the ICO SMEs and Entrepreneurs Facility) is focused on entrepreneurs. Monitoring and evaluation of initiatives is still scarce and partial."

Analysing results of microcredit programmes, there are more hurdles for women-owned firms than menowned firms, in part due to differences in owner and firm profiles. Women-owned firms are, on average, more likely to operate in the services sectors and trades, and are smaller in size than firms owned by men. Compared to men microcredit recipients, women recipients are more likely to be unemployed ( $23 \%$ vs. $35 \%$ ) and less likely to have been previously self-employed (51\% vs. $33 \%$ ) (Microbank, 2014). A positive outcome of microcredits for recipients is increased entrepreneurial self-efficacy and independence, which is higher for women compared to men (73\% and 65\%) (Microbank, 2014). Approximately half of microcredit recipients perceived that their firm's operation was going "well" or "very well", being higher among men than women ( $59 \%$ vs. $53 \%)$. Women recipients were more likely to perceive that microcredit was crucial to creating their firms compared to men (66\% vs. $53 \%)$, however, women reported more difficulties in reaching financial month ends (Microbank, 2014). Even though $62 \%$ of women entrepreneurs report that their businesses generated enough revenue to repay the loan from the beginning, one fifth $(20 \%)$ stated that their business did not generate enough revenue or liquidity to pay the loan fees (Microbank, 2014).

Almost half $(49 \%)$ of all entrepreneurs operating a business perceived their current economic situation was worse than if they had not been granted microcredit, with no significant gender differences; a percentage that increases to $72 \%$ among those who had to close their businesses (Microbank, 2014). Firm survival rate among women-owned small businesses is lower than for that of men-owned firms $(76 \%$ vs. $82 \%$, respectively) (Microbank, 2014). The majority of Microbank's microcredit beneficiaries closed their businesses within the first two years of operation (57\%), a period in which micro-enterprises are typically most vulnerable to closure (Cordobés et al., 2010). These gender differences in business performance and owners' perceptions suggest the need to make the terms of lending (such as, the grace period) more flexible for women, with provisions of follow-on advisory services for more than six months (terms offered by the PAEM's programme) in order that lenders can repay the loan while business remain in operation.

\section{Conclusions and recommendations}

Women entrepreneurs are taking on greater risks and commercial responsibilities, while increasing their economic empowerment and financial autonomy. To achieve equitable participation in entrepreneurship, there remains the need to introduce policies with positive social and economic outcome measures, to add "gender dimensions" to financing policies, and to recognise differentiated needs among entrepreneurs. That is, there is a need to contextualise the experiences of women entrepreneurs to create appropriate lending programmes.

An illustrative regional programme that includes a "gender dimension" is the Programme "Financia Adelante" ("Go Ahead Funding"), which is managed by the Finance Institute of Castilla La Mancha (IFCLM). The programme provides subsidised lending to incorporated or unincorporated entities in order to encourage start-up or the consolidation of activities. The programme reflects positive discrimination for projects promoted by priority groups, including women, youth, people over 55 years old, long-term unemployed, people with disabilities, and depopulated regions. It considers intersectionality, such as disabled women in a rural priority area. In the case of collective projects, the company is assessed as a priority when at least $50 \%$ of capital is owned by applicants who meet the priority group criteria. The projects presented by micro-SMEs are also given priority (e.g. firms with fewer than 10 employees and less than EUR 2 million on the balance sheet). Different funding instruments are complemented with the provision of one year of business consultancy and terms (i.e. interest rates) that are much better than those offered by Microbank-PAEM. 


\section{Recommendations for Spain}

- Create finance policies with a gender dimension, being conscious of the discrete needs of women entrepreneurs. Examples include financial products with more flexible loan conditions and advisory services involving longer periods of advisory support.

- Consider, as a priority, support for women entrepreneurs with high-growth potential firms in technology sectors.

- Foster closer collaboration among financial institutions and small business intermediaries to improve the scope of these initiatives targeted at women-owned firms.

- Create a "women's entrepreneurship approach" within financial lending institutions. This should include requiring banks to account for their performance with respect to gender equality, demonstrating equitable treatment of applications and risk evaluations. The approach should support actions that enhance women's confidence in obtaining financing, and that reduce negative perceptions about accessing capital (i.e. create a specific department for analysing women's applications for funds).

- Provide free consultancy to women beneficiaries of microcredits in the first one or two years of business to increase the probability that these entrepreneurs are able to sustain their business and repay the microcredit.

\section{References}

Barinaga, E. (2014), "Microfinance in a developed welfare state: A hybrid technology for the government of the outcast", Geoforum, Vol. 51, pp. 27-36. https://doi.org/10.1016/j.geoforum.2013.09.008.

De la Fuente-Cabrero, C., M. Segovia-Pérez and C. Figueroa-Domecq (2014), "Evaluación de los efectos del apoyo institucional a la financiación del emprendimiento femenino", Esic Market Economics and Business Journal, Vol. 45, No. 3, pp. 533-552, doi: 10.7200/esicm.149.0453.3e.

Centro para el Desarrollo Tecnológico Industrial (CDTI, 2008), "Funding of Public Research Development and Innovation Policies. Symposium on International comparison of the budget cycle in research development and innovation policies", Madrid, 3 July 2008, https://www.oecd.org/general/searchresults/?q=CDTI\%20spaoin\&cx=012432601748511391518:xzea dub0b0a\&cof=FORID:11\&ie=UTF-8.

Europapress (2020), "La Cámara de Comercio de España y Cesce apoyarán a las mujeres emprendedoras y empresarias", https://www.europapress.es/economia/macroeconomia00338/noticia-camara-comercio-espana-cesce-apoyaran-mujeres-emprendedoras-empresarias20200304113724.html (accessed 16 May 2020).

Cordobés, M., M. Iglesias and B. Sanz (2010), "Informe sobre el impacto de los microcréditos", Microbank: Barcelona, http://itemsweb.esade.es/wi/research/iis/publicacions/MicrocreditosMicrobank-CAST.PDF.

GEM (2019), "Global Entrepreneurship Monitor Global Report 2018-19”, https://www.gemconsortium.org/report/gem-2018-2019-global-report (accessed 4 April 2019).

GEM (2016), "Global Entrepreneurship Monitor Special Report: Women's Entrepreneurship", http://gemconsortium.org/report/49281 (accessed 18 May 2017).

Microbank (2014), "Informe sobre el impacto de los microcréditos 2014", https://www.microbank.com/deployedfiles/microbank v2/Estaticos/PDFs/Informe impacto microcredi tos 2014 es.pdf.

OECD (2018), Financing SMEs and Entrepreneurs 2018: An OECD Scoreboard, OECD Publishing, 
Paris. http://dx.doi.org/10.1787/fin sme ent-2018-en.

OECD (2017), Entrepreneurship at a Glance 2017, OECD Publishing, Paris, https://doi.org/10.1787/entrepreneur aag-2017-en (accessed 6 May 2018).

OECD/EU (2018), "Policy Brief on Women's Entrepreneurship”, OECD SME and Entrepreneurship

Papers, No. 8, OECD Publishing, Paris, https://doi.org/10.1787/dd2d79e7-en.

Ortega, I. (2012), "Las políticas públicas para la promoción de la capacidad emprendedora en España”, Revista Economistas, Vol. 132, pp. 66-71.

https://privado.cemad.es//revistas/online/Revistas/0132.pdf/149.

Ruiz Garijo, M. (2015), "Políticas públicas a favor del emprendimiento de las mujeres”, Economía

Exterior, Vol. 72, pp. 113-120, https://www.politicaexterior.com/revista/economia-

exterior/?numero=72.

Sena, V., J. Scott and S. Roper (2012), "Gender borrowing and self-employment: Some evidence for England", Small Business Economy, Vol. 38, pp. 467-480.

https://link.springer.com/article/10.1007/s11187-010-9272-9.

World Economic Forum (2018), "The Global Gender Gap Report 2018", https://www.weforum.org/reports/the-global-gender-gap-report-2018.

\section{Note}

1 TEA measures the proportion of women and men who are actively working on starting a business, or who are the owner-manager of a business that is less than 42 months old. 


\section{United States}

By Susan Coleman, University of Hartford

\section{Background}

Although women-owned firms represent an estimated $40 \%$ of all small and medium-sized enterprises in the United States, access to financial capital remains a significant challenge for many women entrepreneurs (NWBC, 2018a). On average, women entrepreneurs launch their firms with smaller amounts of financial capital than men, and are more reliant on internal sources of financing (Coleman and Robb, 2016; Henry et al., 2017; OECD, 2017a). The gender gap in access to finance is particularly wide in the area of external equity, which is typically supplied by angel and venture capital investors and used to support growth-oriented businesses. This gap is caused by supply and demand-side barriers. Supply-side barriers include investor preferences for industries with the greatest growth potential (e.g. high-tech and STEM sectors), where women are even more under-represented, a lack of women investors and the significance of male-dominated networks (Henry et al., 2017). Demand-side barriers include, on average, higher levels of risk aversion and lower levels of entrepreneurial self-confidence (OECD/EU, 2017b). The combined effects of supply and demand side constraints result in lower levels of external finance at startup and in subsequent stages of business development (Coleman and Robb, 2016). This has implications for their firms' ability to survive, innovate, create jobs and most importantly, to grow.

Growth-oriented entrepreneurship is a policy priority in the United States due to its potential for job creation and the development and commercialisation of innovative products and services. Growth-oriented ventures also have the potential to generate significant tax revenues at the national, state and local levels. A report published by the Ewing Marion Kauffman Foundation found, however, that women are dramatically under-represented in growth-oriented entrepreneurship (Mitchell, 2011). Despite these gaps, successful women entrepreneurs are increasingly recognised not only as leaders in their industry, but also as thought leaders and role models in our society.

\section{Policy issue: Access to financial capital}

Although women represent nearly $40 \%$ of the top wealth holders in the United States, they accounted for only $19.5 \%$ of angel investors in 2017 (Sohl, 2018). This under-representation of women within networks of angel investors represents another hurdle for women entrepreneurs, since male investors are more likely to invest in firms launched by men rather than those launched by women. Women also tend to be less confident, on average, in their financial and investing skills, which likely increases their reluctance to become angel investors. In response to these challenges, evaluation evidence shows that angel investor training programmes for women that combine education, hands-on investing, and the creation of a mutually supportive network can lead to gains in knowledge, confidence and willingness to invest in women-owned enterprises (Coleman and Robb, 2018).

Only $2.7 \%$ of firms that received venture capital funding between 2011 and 2013 had a woman CEO (Brush et al., 2014). Correspondingly, companies with a woman CEO received only $3 \%$ of total venture capital investment during this period. Moreover, the number of women partners in venture capital firms declined from $10 \%$ in 1999 to $6 \%$ in 2013 (Brush et al., 2014). Significantly, 34\% of venture capital firms with a woman partner invested in companies with a woman on the management team compared to $13 \%$ of firms without a woman partner. These observations underscore the need to increase the number of women investors and decision-makers in both angel investing and venture capital.

In 2012, the U.S. Congress passed the Jumpstart Our Business Startups Act (JOBS Act) to support and encourage entrepreneurship and small business growth in the wake of the financial crisis. Among other measures, the JOBS Act opened the door to equity crowdfunding and the emergence of a growing number 
of crowdfunding platforms. Preliminary results suggest that crowdfunding may be particularly beneficial to women entrepreneurs. A recent study of women entrepreneurs participating in Kickstarter campaigns revealed that, although women set lower funding goals, they were 9 percent more likely to achieve their goals in both men-dominated and women-dominated categories (NWBC, 2018b, pp.13). Given that Kickstarter applies an "all or nothing" funding rule, this means that a higher percentage of women get funded relative to those that apply. Early successes such as these highlight the potential for developing women-focused or women-friendly crowdfunding platforms as a means for increasing the supply of financial capital available to women entrepreneurs.

\section{Conclusions and recommendations}

Women are significantly less likely than men to launch growth-oriented firms in the United States. One of the primary barriers cited to women's growth-oriented entrepreneurship is lack of access to financial capital, particularly equity capital in the form of angel and venture capital. Recent research suggests that reshaping the entrepreneurial ecosystem by increasing the number of women angel and venture capital investors is a means for increasing the amount of equity capital available to growth-oriented women entrepreneurs. Similarly, the emergence and growth of crowdfunding, further stimulated by the 2012 JOBS Act, provides opportunities for new sources of financing for both growth-oriented and non-growth-oriented women-owned firms. Based on the United States experience, the following recommendations are offered for policy makers seeking to improve access to financial capital for growth-oriented women entrepreneurs.

\section{Recommendations for the United States}

- Develop women-focused business angel training programmes, networks and funds that combine education and training in the principles of angel investing with hands-on investing experience under the direction of experienced angel investors.

- Increase the number of women venture capitalists in decision-making roles by encouraging the venture capital industry to recruit, train, develop and retain women in leadership positions.

- Develop the potential of crowdfunding to increase the supply of external financial capital to all women entrepreneurs, including those who aspire to grow their businesses.

\section{References}

Brush, C. G., P. G. Green, L. Balachandra and A. Davis (2014), Women Entrepreneurs 2014: Bridging the Gender Gap in Venture Capital; Executive Summary, Arthur M. Blank Center for Entrepreneurship, Babson College, Babson Park, MA, www.babson.edu/.../diana-project-executivesummary-2014.pdf.

Coleman, S. and A. Robb (2018), Executive forum: Linking women's growth-oriented entrepreneurship policy and practice: Results from the Rising Tide Angel Training Program, Venture Capital, Vol. 20, No. 2, pp. 211-231.

Coleman, S. and A. Robb (2016), Financing high-growth women-owned enterprises: Evidence from the United States in C. Díaz-García, C. Brush, E. Gatewood and F. Welter (eds.), Women's Entrepreneurship in Global and Local Contexts, Edward Elgar Publishing, Cheltenham, UK and Northampton, MA, USA: pp. 183-202.

Henry, C., B. J. Orser, S. Coleman, L. Foss and F. Welter (2017), Women's entrepreneurship policy: A 13 nation cross-country comparison, International Journal of Gender and Entrepreneurship, Vol. 9, No. 3, pp. 206-228.

Mitchell, L. (2011, September), Overcoming the Gender Gap: Women Entrepreneurs as Economic 
Drivers, Ewing Marion Kauffman Foundation, Kansas City, MO, http://www.kauffman.org.

NWBC (2018a), National Women's Business Council 2018 Annual Report, National Women's Business Council, Washington D.C., https://www.nwbc.gov/2018/12/21/annual-report-2018/.

NWBC (2018b), Crowdfunding as a Capital Source of Women Entrepreneurs: Case Study of Kickstarter, a Reward-Based Crowdfunding Platform, National Women's Business Council, Washington D.C., https://www.nwbc.gov/2018/03/27/crowdfunding-as-a-capital-source-for-women-entrepreneurs-2/.

OECD (2017a), The Pursuit of Gender Equality: An Uphill Battle, OECD Publishing, Paris, https://doi.org/10.1787/9789264281318-en.

OECD/EU (2017b), The Missing Entrepreneurs 2017: Policies for Inclusive Entrepreneurship, OECD Publishing, Paris, https://doi.org/10.1787/9789264283602-en.

Sohl, J. (2018), The Angel Market in 2017: Angels Remain Bullish for Seed and Start-Up Investing, Center for Venture Research, University of New Hampshire, Durham, New Hampshire, https://paulcollege.unh.edu/sites/default/files/resource/files/2017-analysis-report.pdf. 



\section{Supporting networks for women entrepreneurs}

Business networks of entrepreneurs help them to access resources including finance, advice and business ideas, as well as connections to markets and suppliers. Yet, women entrepreneurs typically have smaller and less developed business networks compared to men entrepreneurs. This chapter discusses the main policy issues related to strengthening entrepreneurship networks and local entrepreneurial ecosystems for women entrepreneurs. Policy insight notes on the Palestinian Authority and Scotland (UK) are presented to illustrate this discussion. Success factors and lessons are highlighted. 


\section{The importance of entrepreneurship networks and supportive ecosystems}

Entrepreneurship networks link existing and prospective entrepreneurs to other entrepreneurs, business service providers and other actors in reciprocal relationships that offer information and support. These networks play other important roles in helping entrepreneurs develop their projects - e.g. by facilitating access to finance, identifying business partners, suppliers, employees and customers, and stimulating ideas for new products, processes, organisational methods and business models. Networking can also positively impact entrepreneurial intentions and the ability to identify and exploit business opportunities (OECD/EU, 2019). Networking can provide cost-effective advice, access to finance, emotional support and social legitimacy (Hanson and Blake, 2009).

However, women and men's networking behaviours often differ (Minniti, 2017). Women's entrepreneurial networks are typically smaller, comprising more family and friends than business connections; having fewer "weak ties", more homogenous contacts, and are less extensive than men's networks (OECD/EU, 2018; Henry et al., 2020). Women entrepreneurs, on average, typically have smaller and more informal networks than their men counterparts. Consequently, they are less likely to interact with individuals who control key resources (Brush et al., 2004). One of the factors that explains the tendency to have weaker entrepreneurship networks is that women often have had fewer opportunities to build professional relationships in educational, workplace and social contexts compared to men. Moreover, women entrepreneurs are less inclined to join business associations, special interest groups and large formal networks (Klyver, 2011). Accordingly, when it comes to networking, women may be disadvantaged compared to their men counterparts (Foss, 2017).

Similarly, women tend to be less embedded than men in entrepreneurial ecosystems. An entrepreneurial ecosystem can be defined as a:

"set of interconnected entrepreneurial actors (both potential and existing), entrepreneurial organisations (e.g. firms, venture capitalists, business angels, banks), institutions (universities, public sector agencies, financial bodies) and entrepreneurial processes (e.g. the business birth rate, numbers of high growth firms, levels of 'blockbuster entrepreneurship', number of serial entrepreneurs, degree of sell-out mentality within firms and levels of entrepreneurial ambition) which formally and informally coalesce to connect, mediate and govern the performance within the local entrepreneurial environment" (Mason and Brown, 2014).

Entrepreneurial ecosystems can have a strong influence on business development and growth because firms do not exist on their own in a vacuum, rather, they interact with suppliers, customers, financiers and other actors in the local area and beyond. Entrepreneurship policy is increasingly focusing on holistic activities that support entrepreneurial ecosystems as a whole, rather than activities targeted at the individual entrepreneur or enterprise (Stam, 2015). This more holistic approach involves supporting a range of informal and formal intermediaries including banks, universities/colleges, small business and innovation support organisations, and industry networks (Isenberg, 2010).

Women entrepreneurs, however, often find it difficult to become fully integrated within local entrepreneurial ecosystems. Significant barriers include their smaller and less effective networks and lower levels of perceived legitimacy of their businesses. Strengthening entrepreneurial ecosystems and the participation of women in them is important given that "women especially benefit from strong entrepreneurship contexts" (GEM, 2018/2019). Dedicated networks and institutions for women entrepreneurs may often be required.

A systematic review of literature on women's enterprise ecosystems recently concluded that most policy recommendations by academics are "vague, conservative, and centre on identifying skills gaps in women entrepreneurs that need to be fixed, thus isolating and individualising any perceived problem" (Foss et al., 2019). Attention is needed to strengthen the accessibility of small business support organisations to women entrepreneurs; addressing challenges in recruiting diverse (non-white, privileged) clients to these organisations, and changing the organisational cultures and tolerance of gender bias (Orser et al., 2019). 
Lack of monitoring of the performance of high-status publicly-funded entrepreneurship support programmes further stymies inclusiveness.

Furthermore, reporting on women's entrepreneurship by agencies such as the United Nations, International Labour Office and the World Bank tends to emphasise necessity-based entrepreneurship, self-employment and poverty alleviation. However, it is opportunity-driven entrepreneurship that motivates the majority of women in developed economies (Global Entrepreneurship Monitor, 2018/2019). Conversely, most studies about women entrepreneurs and entrepreneurial ecosystems are situated in the Global North, with findings that remain "largely untested in the developing contexts of the Global South" (Apostolopoulos et al., 2018).

\section{The role of public policy}

One of the main areas of public policy action to support the access of women entrepreneurs to resources is the creation of networks focused on bringing entrepreneurs together or linking groups of entrepreneurs with business services professionals in local entrepreneurial ecosystems. A common approach is to link network creation to an entrepreneurship training programme, which creates a commonality to the network. Policy can bring entrepreneurs together into online networks, or link small local networks into larger national networks that provide greater opportunities to access resources. Many initiatives focus on networks of women entrepreneurs specifically. This helps to build strong connections quickly because it is easier to build trust among people with common traits. However, in addition, policy needs to build bridges to stakeholders from other communities.

Key success factors for policy support for women's entrepreneurship networks are: 1) network structures and processes that ensure a high degree of interaction between members; 2) network members feeling ownership of the network; and 3) networks being proactive. Policy makers must be careful not to create a plethora of entrepreneurship networks that crowd each other out. It is also important that support does not reinforce the exclusion of women entrepreneurs from mainstream networks and resources by focussing solely on links among women rather than building connections with others in the ecosystem.

\section{Lessons from the policy cases}

The policy insight notes in this section (Palestinian Authority and Scotland, UK) highlight the need for specific support for entrepreneurship networks for women. They suggest that policy interventions to enhance entrepreneurial ecosystems generally do not yet recognise the needs of women entrepreneurs. These observations are consistent with international research that shows a lack of gender-sensitive mainstream interventions and limited women-focused programme support (Henry et al., 2017; Coleman et al., 2018). Government funding criteria and programme assessments are not typically accountable for the inclusion of women entrepreneurs.

These two insight notes highlight the following lessons for policy makers in other countries:

1. Networking support is especially important for women entrepreneurs. For a variety of reasons, women entrepreneurs may not have access to the same supports and resources as men. Networking programmes can be a vital support. They need to be organised and co-ordinated, involve all relevant stakeholder groups and avail of appropriate platforms including digital platforms.

2. Networking programmes should not be offered in isolation, but in conjunction with other supports. It is particularly relevant to package networking support with mentoring and entrepreneurial skills development programmes for women. 
3. There is insufficient access of women entrepreneurs to high-quality policy and non-policy supports offered in entrepreneurial ecosystems. This reinforces the low status and legitimacy of the womenfocused advisory services offered.

4. More funding is needed for women-focused organisations and initiatives in entrepreneurial ecosystems. This support should foster more inclusive entrepreneurship cultures, address gender barriers within mainstream interventions, strengthen the design of women's entrepreneurship supports and build more supportive legal, cultural and regulatory environments for women entrepreneurs.

\section{References}

Apostolopoulos, N., H. Al-Dajani, D. Holt, P. Jones and R. Newbery, R., (2018), "Entrepreneurship and the Sustainable Development Goals," in G. McElwee and P. Jones (eds.), Contemporary Issues in Entrepreneurship Research, Vol. 8.

Bosma, N., and D. Kelley (2019), "Global Entrepreneurship Monitor 2018/2019 Global Report”, Babson Park: Global Entrepreneurship Research Association.

Coleman, S., C. Henry, B. Orser, L. Foss, and F. Welter (2018), "Policy Support for Women Entrepreneurs' Access to Financial Capital: Evidence from Canada, Germany, Ireland, Norway, and the United States", Journal of Small Business Management.

Foss, L., C. Henry, H. Ahl and G. H. Mikalsen (2019), "Women's entrepreneurship policy research: a 30-year review of the evidence", Small Business Economics, Vol. 53, No. 2, pp. 409-429.

Henry, C., B. Orser, S. Coleman, L. Foss and F. Welter, F. (2017), "Women's entrepreneurship policy: a 13-nation cross-country comparison", in Entrepreneurial Ecosystems and Growth of Women's Entrepreneurship, Edward Elgar Publishing.

Isenberg, D. J. (2010), "THE BIG IDEA how to start an entrepreneurial revolution," Harvard Business Review, Vol. 88, No. 6, pp. 40.

Mason, C. and R. Brown (2014), "Entrepreneurial Ecosystems and Growth Oriented Entrepreneurship", prepared for the OECD, https://www.oecd.org/cfe/leed/entrepreneurial-ecosystems.pdf.

Orser, B., C. Elliott and W. Cukier (2019), "Strengthening Ecosystem Supports for Women Entrepreneurs," Telfer School of Management, University of Ottawa and Ryerson University Diversity Institute, http://sites.telfer.uottawa.ca/were/.

Stam, E. (2015), "Entrepreneurial ecosystems and regional policy: a sympathetic critique," European Planning Studies, Vol. 23, No. 9, pp. 1759-1769.

Women, U. N. (2016), “Leave No One Behind: A Call to Action for Gender Equality and Women's Economic Empowerment”, Report of the UN Secretary General's High Level Panel on Women's Economic Empowerment.

World Economic Forum (2016), "The Global Gender Gap Report 2016," Geneva, http://reports.weforum.org/global-gender-gap-report-2016/. 


\section{Palestinian Authority}

By Grace Khoury, Birzeit University

\section{Background}

The Palestinian economy is characterised by a difficult and volatile context, especially given regular instability, fragmented markets and high dependence on donor support. As a result of the 1993 Oslo Agreement, the Palestinian Authority was granted competence over the enterprise development agenda, such as SME policy, innovation, access to finance and capacity building with limitations regarding trade and territorial development (OECD, 2018).

Most entrepreneurship programmes are implemented by civil society, not-for-profit and non-governmental organisations (NGOs) funded by foreign governments and international donor agencies. To date, entrepreneurship programmes, which include business incubators, accelerators and business development services, have had minimal impact and have not met Palestinians' expectations. This is due, in part, to a lack of an SME and entrepreneurship policy. The development agenda is framed by a number of policy documents such as the National Policy Agenda 2017-2022, which includes a series of priorities and objectives in terms of creating job opportunities, improving the business environment and promoting Palestinian industry. However, there are no formal co-ordination mechanisms and there is no SME and entrepreneurship strategy yet developed, although there have been discussions on this issue by the Ministry of National Economy and the Palestinian Federation of Industries (OECD, 2018). Donor agencies fund similar programmes, with very limited coordination among stakeholder groups, creating redundant efforts in the area of entrepreneurship. Capacity building, access to finance, access to markets, networks and other initiatives are replicated by governmental agencies, donor countries, private organisations and NGOs rather than uniting in a clear vision to promote entrepreneurship in general and women's entrepreneurship in particular (Khoury, Farraj and Sultan, 2018).

Women account for half of the five million citizens (PCBS, 2018a), with a literacy rate of 95.6\% (PCBS, 2018b). In 2018, unemployment rates were $30.2 \%$ overall; $49.1 \%$ in Gaza and $18.3 \%$ in the West Bank. Moreover, the labour force participation rate of women was less than $20 \%$. The level of women's entrepreneurial activity is also low at 3.4\% (Abdullah and Hattawy, 2014). In light of these indicators, a policy to create new jobs and to empower and promote the underlying entrepreneurial potential of women as a basis for economic growth is essential.

In 2018, the Ministry of National Economy of the Palestinian Authority responded to calls for genderresponsive policies by developing a strategy and policy framework for women's entrepreneurship. This policy has not yet been approved by the Cabinet. Once approved and effectively implemented, it is expected to end redundant and random efforts, which have not contributed effectively to entrepreneurship overall or to women's entrepreneurship specifically in recent years.

\section{Policy issue: Entrepreneurship networks and mentoring}

The OECD/EU (2017) states that networks assist women in gaining greater social and economic power. This, in turn, assists in greater accessibility to information, resources and referral to networking opportunities. However, Palestinian women entrepreneurs face additional cultural barriers compared to men when trying to engage in networking opportunities, particularly informal gatherings (Muna and Khoury, 2012). Although there has been progress in recent years, it is still more difficult for women to engage in networking and maximise relationship opportunities. Overall, entrepreneurship networks of women entrepreneurs are less effective than those of men because they are smaller and less diverse (OCED/EU, 2017). In addition to these constraints, Palestinian women also have to overcome the social mores of Arab societies. For example, it is deemed more socially acceptable for men to meet in venues such as cafes to 
discuss business than it is for women (Muna and Khoury, 2012). These social norms also impose constraints on women working at night or leaving children in nurseries. Moreover, it is very easy for business meetings to be misinterpreted, especially those involving men. These misinterpretations influence perceived reputations which exacerbate criticism of women engaged in such activities.

It is also reported that Palestinian women face challenges with respect to access to finance, as they are often denied finance or require complex guarantees and securities if they wish to gain access to venture capital. Additionally, both men and women face challenges imposed by the political and regulatory environment, which influences their ability to access markets and international payments for their products (McNally and Khoury, 2018). While formalised networks are scarce, they are deemed to be one of the more important support systems by which women entrepreneurs can grow and expand their business.

International case studies show that mentoring programmes are essential for women entrepreneurs (for example: Hot Mommas Project stories, classes and group coaching, and The Cherie Blair Foundation's training and mentoring). Nevertheless, it is more difficult for mentoring programmes to be developed in Arab countries, where social mores preclude the use of men mentors, since women entrepreneurs (and mentors) are still in a minority. Thus, women's ability to obtain expert advice in accessing finance, business service providers and women role models is constrained. A good example in the Palestinian Authority is the task force led by the Business Women Forum (BWF) which provided networking opportunities and managed to cooperate with multi-stakeholder groups to facilitate new business registry, capacity building, marketing and access to finance for women entrepreneurs.

\section{Conclusions and recommendations}

Women's entrepreneurship support requires more than a policy intervention statement. There is a requirement for firmer policy directions and a formalised strategy. The establishment and adoption of a sound SME policy ensuring gender-related provisions that assist women to overcome the challenges they face is essential. The successful role that women's networking organisations have in supporting new ventures cannot be ignored. Development of these networks is imperative if women's entrepreneurship is to further develop and thrive.

The use of internet-based resources to develop a women's entrepreneurship network through a dedicated website would help overcome the constraints imposed by the geographic separation of the Gaza and the West Bank. There are examples of such initiatives found elsewhere. However, it is important that such a network is developed and maintained by women based in the Palestinian Territory to ensure that it meets their needs.

This framework can support the development of mentorship programmes, whether they are one-to-one or group-based. The use of web-based technology will assist in meeting the challenges imposed by social norms and geographic separation. This could include the matching of mentors and mentees, and include more women mentors to overcome social restrictions. There is also the potential to develop case studies which would serve to provide role models for aspiring women entrepreneurs. 


\section{Recommendations for the Palestinian Authority}

- Adopt a sound entrepreneurship policy with gender-related provisions, and designate an official SME agency in charge of the implementation and coordination of the many initiatives already in place.

- Involve women business associations in the initiation of a national networking platform with a dedicated website that provides information and support for women to start and maintain their businesses.

- Introduce one-to-one or group mentorship programmes through the national networking platform to match successful mentors and mentees.

\section{References}

Abdullah, S. and M. Hattawy (2014), "Policies for scaling up female entrepreneurship in the State of Palestine, Palestine Economic Policy Research Institute (MAS), Ramallah.

Khoury, G., W. Farraj, and S. Sultan (2018), "Challenges to the formalization of Palestinian femaleowned homebased businesses", in S. Yousafzai, A. Fayolle, A. Lindgreen, C. Henry, S., Saeed and S. Sheikh (eds.), Women Entrepreneurs and the Myth of "Underperformance": A New Look at Women's Entrepreneurship Research, pp. 173-191, Edward Elgar Publishing, Cheltenham UK.

Khoury, G., and McNally, B. (2016), "Importance of fostering alignment to ensure sustainable nation building: The role of HRD in large Palestinian organizations", Journal of Management Development, Vol. 35, No. 6, pp. 718-734.

McNally, B. and G. Khoury (2018), "Leveraging micro-level support factors to overcome macro-level challenges: Palestinian and Saudi Arabian female entrepreneurs", in S. Yousafzai, A. Lindgreen, S. Saeed and C. Henry (eds.), Contextual Embeddedness of Women's Entrepreneurship Going Beyond a Gender Neutral Approach (1st ed.), pp. 60-73, Routledge, NY USA.

Muna, F. and G. Khoury (2012), The Palestinian Executive: Leadership Under Challenging Conditions, Gower, Surrey England.

National Policy Agenda 2017-2022 (Dec 2016), Putting Citizens First, Palestine, https://planipolis.iiep.unesco.org/sites/planipolis/files/ressources/palestine draft final npa.pdf (accessed 14 May 2019).

OECD (2018), SME Policy Index, The Mediterranean Middle East and North Africa 2018, Interim Assessment of Key SME Reforms, OECD Publishing, Paris.

OECD/EU/ETF (2018), The Mediterranean Middle East and North Africa 2018: Interim Assessment of Key SME Reforms, SME Policy Index, OECD Publishing, Paris, https://doi.org/10.1787/9789264304161-en.

OECD/EU (2017), "Policy Brief on Women's Entrepreneurship", OECD Publishing, Paris, https://doi.org/10.1787/f493861e-en https://www.oecd.org/cfe/smes/Policy-Brief-on-Women-sEntrepreneurship.pdf (accessed 13 July 2019).

Paprock, K. E. (2006), "National human resource development in transitioning societies in the developing world: Introductory overview", Advances in developing human resources, Vol. 8, No. 1, pp. 12-27.

Palestinian Central Bureau of Statistics PCBS (2020), "Labour Force Survey Preliminary Results (First quarter January-March 2020)", www.pcbs.gov.ps/post.aspx?lang=en\&ltemID=3748\# (accessed 20 June 2020).

Palestinian Central Bureau of Statistics PCBS (2019), Press Release by Palestinian Central Bureau of Statistics (PCBS) on the occasion of International Literacy Day, 08/09/2019 
http://pcbs.gov.ps/site/512/default.aspx?lang=en\&ltemID=3543 (accessed 20 June 2020).

Palestinian Central Bureau of Statistics PCBS (2018a), Press Release on The Results of The Labour Force Survey First Quarter (January-March, 2018) Round

http://www.pcbs.gov.ps/post.aspx?lang=en\&ltemID=3135\# (accessed 18 March 2019).

Palestinian Central Bureau of Statistics PCBS (2018b), Press release on the Eve of the International Women's Day on Tuesday, 08/03/2018, http://www.pcbs.gov.ps/post.aspx?lang=en\&ltemID=1866\# (accessed 18 March 2019). 


\title{
Scotland, United Kingdom
}

\author{
By Anne F. Meikle
}

\section{Background}

In Scotland, United Kingdom, one-fifth of all small and medium-sized enterprises (SMEs) are majority women-owned. Collectively, women-owned businesses contribute over GBP 8.8 billion (approximately EUR 9.7 billion) to the Scottish economy, and constitute $13.3 \%$ of private sector employment.

Scotland has a long-standing policy framework for women's enterprise. ${ }^{1}$ Economic development has been devolved to the Scottish government with the inception of the Scottish Parliament in 1999, creating additional opportunities for women to engage in policy development. The Scottish Framework and Action Plan for Women in Enterprise aligns women's enterprise policy with other national policy priorities, including the economy, labour market and entrepreneurship (Scottish Government, 2017); the framework is listed within the Scottish Government's Economic Action Plan (2018, p. 20) as part of the strategy to drive entrepreneurship. Within the Scottish Parliament, delivery of the framework is supported by an action group chaired by the Minister for Business, Fair Work and Skills. The Women in Enterprise Action Group aims to "Realise untapped economic potential by tackling the gender gap across start-ups and growth companies, with action to deliver a sustainable model that collaboratively develops and monitors future gender-aware and gender-specific policies and interventions" (Scottish Government, 2017). ${ }^{2}$

Research finds that women entrepreneurs in Scotland are disadvantaged at various stages of business development (Federation of Small Business, 2016). Barriers such as: the availability of gender-aware startup business support; few networking structures; lack of support for their business ideas, and limited access to low cost finance in early development have an effect on business growth. Support for childcare is also a key issue for women entrepreneurs. The policy framework seeks to address these barriers through actions, such as: improved measurement and use of sex-disaggregated data; creation of mentoring and networking opportunities; development of a women ambassadors programme; funding support for SME growth programmes; increased access to capital, and provision of gender-focused small business supports. Challenging gender stereotypes and misperceptions about women entrepreneurs and entrepreneurship as a career choice through education will also contribute to closing gender gaps (OECD/EU, 2017).

By way of counteracting the effects of gender stereotyping, there is an increase in calls for a greater focus on understanding and meeting the needs of women entrepreneurs through policy (EIGE, 2014).

\section{Policy issue: Creating a gender-focused business support eco-system}

Adopting a gender-focused approach to small business support is essential to ensure support services meet the needs of all entrepreneurs. On average, women entrepreneurs seek and prefer different kinds of advice to men, and seek more advice, particularly in the early stages of venture creation (Yazdanfar and Abbasian, 2015; EIGE, 2017).

Similar to other OECD economies, women entrepreneurs in Scotland tend to operate in certain sectors (OECD/EU, 2017). These sectors are not those which policy makers perceive to be ones with "high-growth" potential. Typical growth trajectories of women-owned businesses differ from those of men-owned businesses; this may be for a variety of reasons, including a need for women to balance business and family responsibilities. Women's growth intentions can also be poorly matched to available business supports. Although micro and small businesses owned by women provide employment in local economies, and collectively make a significant contribution to the Scottish economy, small business services do not offer services of equal quality or status to companies being run by women (Federation of Small Businesses, 2018). Women have also expressed concern that a "hierarchy" of business support exists, with businesses 
in the more favoured growth sectors (mostly men dominated) receiving more specialised and tailored support while other sectors (mostly women dominated) receive a reduced access level of support (Women's Enterprise Scotland, 2017; 2018). With a business landscape that is predominantly men dominated, strategies are required to mitigate outcomes where women entrepreneurs may have been missed.

Small business support services typically employ a "one size fits all" client approach. While this approach can claim to be "gender neutral" it can result in failure if services do not recognise that policies and programmes can have a different impact on women and men. A recent Scottish Parliament Committee Inquiry into business support services remarked that existing support packages are not suitable for all businesses, suggesting that "a range of tailored programmes" is required, with consideration given to how existing supports assist under-represented groups of entrepreneurs, including women. The Committee also recommended that the government create a national role (a Head of Women in Business) to coordinate policy in business support (Scottish Parliament, 2019).

Pre-start or early business stage supports produce economic benefits. In Scotland, such supports are not broadly available or accessible. Research by Women's Enterprise Scotland reports on the lack of mainstream business support for women-led businesses that have evolved from early start-up but fail to meet the eligibility criteria for next stage business support (e.g. they do not meet the programme expectations on turnover, projected growth or scale-up; they operate in sectors that are not considered to have high growth potential). The "missing middle" impacts the capability of businesses to sustain start up momentum and scale-up; for example, only nine women-led scale-up programmes currently exist in Scotland. ${ }^{3}$

\section{Conclusions and recommendations}

Without an inclusive and informed entrepreneurial ecosystem, women will remain $20 \%$ less likely to benefit from government funded support compared to men (EIGE, 2017). This inhibits economic growth. Despite a policy framework and action plans, women entrepreneurs continue to be restrained by institutional and market failures, making access to resources, such as capital and scale-up programmes, more difficult for women compared to men (OECD/EU, 2017). "Traditional" misperceptions about women entrepreneurs (e.g. women lack ambition, are less capable, and are interested in developing only certain types of smaller businesses) must be challenged through targeted initiatives. More gender-based analyses are required to release the "untapped potential" of women entrepreneurs and further emphasise the importance of womenowned businesses to the Scottish economy (FSB, 2018). 


\section{Recommendations for Scotland, United Kingdom}

- Address the gender gap in enterprise and improve provision of business supports by developing a national women's business centre. The mandate would be to provide physical and digital delivery of "needs-based" small business supports for women, creating appropriate initiatives and interventions through a national headquarters and regional hubs.

- Improve business support for potential women entrepreneurs by strengthening collaboration among ecosystem agencies. This includes aligning local and national policies, including the Framework for Women's Enterprise, and developing a professional diversity training development programme for support staff.

- Undertake gender-based analyses of small business surveys conducted by the Scottish Government to provide more evidence for policy development (e.g. reporting using genderdisaggregated findings).

\section{References}

European Institute for Gender Equality (EIGE) (2017), "Economic Benefits of Gender Equality", https://eige.europa.eu/publications/economic-benefits-gender-equality-eu-economic-benefits-genderequality-eu-policy-context.

European Institute for Gender Equality (EIGE) (2014), "Good Practices in Women's Entrepreneurship", https://eige.europa.eu/publications/factsheet-good-practices-womens-entrepreneurship.

Federation of Small Businesses (2018), "Supporting Women's Enterprise in the UK: The Economic Case", https://www.fsb.org.uk/resource-report/supporting-women-s-enterprise-in-the-uk.html.

Federation of Small Business (2016), "Women in Enterprise: The Untapped Potential", https://www.fsb.org.uk/resources-page/fsb-to-launch-women-in-enterprise-taskforce.html.

OECD/EU (2017), "Policy Brief on Women's Entrepreneurship”, OECD Publishing, Paris, https://doi.org/10.1787/f493861e-en https://www.oecd.org/cfe/smes/Policy-Brief-on-Women-sEntrepreneurship.pdf (accessed 13 July 2019).

OECD/EU (2017), The Missing Entrepreneurs 2017: Policies for Inclusive Entrepreneurship, OECD Publishing, Paris, https://doi.org/10.1787/9789264283602-en.

Scottish Government (2019), "Women and Enterprise", https://onescotland.org/nacwg-news/women-andenterprise-what-we-already-knowl.

Scottish Government (2018), "Economic Action Plan", https://economicactionplan.mygov.scot/.

Scottish Government (2017), "Scottish Framework and Action Plan for Women in Enterprise", https://www.gov.scot/publications/scottish-framework-action-plan-women-enterprise/.

Scottish Parliament (2019), "Business Support. Economy, Energy and Fair Work Committee Report," https://digitalpublications.parliament.scot/Committees/Report/EEFW/2019/2/20/Business-Support-1\#.

Women's Enterprise Scotland (2018), "Response to Scottish Parliament Business Support Inquiry", www.wescotland.co.uk.

Women's Enterprise Scotland (2017), "Women in Enterprise: Research Report”, www.wescotland.co.uk.

Yazdanfar, D., and S. Abbasian (2015), "Gender and the use of external business advice", International Journal of Gender and Entrepreneurship, Vol. 7, No. 1, pp.105-124. 


\section{Notes}

1 The UK Government published a Strategic Framework for Women's Enterprise in 2003.

2 Besides Scottish Government, organisations represented in the action group are Scottish Enterprise, Business Gateway, Royal Bank of Scotland, Virgin Start-up, the Hunter Centre for Entrepreneurship, Women's Enterprise Scotland, Investing Women, the British Association of Women Entrepreneurs, the Association of Scottish Business Women, Entrepreneurial Scotland, and Entrepreneurial Spark.

${ }^{3}$ Women and Enterprise, Scottish Government (2019), https://onescotland.org/nacwg-news/women-andenterprise-what-we-already-knowl. 


\section{Building a supportive regulatory environment for women entrepreneurs}

The regulatory environment can impact business creation in several ways, including through the length and cost of start-up procedures, tax environment, access to social protection measures and family policy measures such as parental leave and childcare. This chapter discusses the main regulatory barriers faced by women entrepreneurs, including genderbiased taxation and family policies that favour working as an employee. Policy insight notes from Kenya, Pakistan and Sri Lanka are included, and lessons for policy makers are identified. 


\section{Supporting women's entrepreneurship through the regulatory environment}

Regulatory institutions are those elements of the legal and regulatory system that influence the costs and feasibility of creating, growing and closing a business. This includes regulations that deal with market entry and exit, conducting transactions, as well as laws and regulations related to the social welfare system, labour market, taxation of income and capital, as well as other policies that directly affect the costs and rewards of entrepreneurship and self-employment relative to other labour market activities.

Regulatory institutions can also indirectly affect individuals' decisions related to entrepreneurship through measures that affect social norms. The interplay between regulatory and normative institutions is complex. But it is important to recognise that supportive regulatory institutions, such as an entrepreneurship-friendly business environment, could be weakened by unfriendly normative institutions that impact entrepreneurship decisions. Conversely, however, entrepreneurship-friendly normative institutions could compensate for unfriendly regulatory institutions.

The number and scale of entrepreneurship activities undertaken by women are strongly influenced by the regulatory environment. Regulatory institutions such as the welfare model, tax policies and family policies have a disproportionate impact on the costs and feasibility of women's entrepreneurship (OECD/EU, 2018; 2013). Tax policies that favour a dual-earner model are likely to foster labour market participation and business activity by women. Maternity and paternity leave provisions have an impact on the general rate of women's entrepreneurship since parental leave systems typically favour those working as employees.

\section{The role of public policy}

The two primary questions for ensuring that regulatory policy is sufficiently supportive of women's entrepreneurship are: 1) does the regulatory environment directly and indirectly influence labour market decisions appropriately (i.e. working as an entrepreneur vs. working as an employee?); 2) does the regulatory environment directly or indirectly impact women entrepreneurs differently than male entrepreneurs?

The most direct levers to influence entrepreneurship decisions are through the tax system. First, the prevalence and nature of women's self-employment is often linked to the income tax model used. When the single provider household model is used (i.e. men are the principal income generator), there tends to be a less developed childcare infrastructure and a higher incidence of part-time women's self-employment. However, a dual-income household model tends to lead to a more developed infrastructure to support families, allowing women entrepreneurs tend to work full-time in their businesses (Strohmeyer et al., 2006). The use of dual household income tax models can therefore be expected to encourage more growthoriented women's entrepreneurship.

Business taxation can also influence women's entrepreneurship when different sectors receive different tax treatment. Women entrepreneurs tend to operate in service sectors, and tax policy may discriminate against women entrepreneurs because they cannot benefit from incentives targeted at specific sectors (e.g. technology) or business legal forms that are male-dominated (García and Garijo, 2014). Governments can review their business taxation systems with a view to removing impediments to entrepreneurship by women.

Governments can also influence women's entrepreneurship through the social protection system. In most countries, there is currently a clear distinction in the benefits that employees and the self-employed can access. Differences in benefits are based on differences in contribution rates and risks faced. For example, a self-employed person has some, or full, control over the end of a business activity, whereas an employer can reduce the number of hours worked by employees, or lay them off. Debate is ongoing in many countries about making social protection less dependent on work-status and employment-related 
contributions. One option is to make social protection a universal benefit that provides defined supports to anyone who meets defined criteria (e.g. with children, of a certain age, a disability) regardless of income. However, such a shift would likely have large public costs and could significantly alter incentives for labour market activities, which would require proper appraisal and monitoring.

\section{Lessons from the policy cases}

The three policy insight notes in this section each cover a different angle on how the regulatory environment impacts women's entrepreneurship. The issues of access to social protection and the formalisation of business activities are discussed in the note from Kenya, while the other two insight notes discuss the importance of having strong regulatory institutions (Pakistan) and a supportive business environment (Sri Lanka).

Together, these three policy insight notes highlight two lessons for policy makers:

1. Strong regulatory institutions are needed to promote and support women's business ownership, including in the areas of parental leave and care responsibilities. Compared with employees, entrepreneurs or the self-employed often have less access to family support. The risk of weak regulatory institutions is that many women entrepreneurs will operate in the informal economy and find "do it yourself" solutions that will cost governments forgone tax revenue and may have a negative impact on the safety and wellbeing of the women undertaking these activities.

2. A lack of social protection for entrepreneurs working in the informal sector, who are mostly women in many countries, contributes to poor perceptions of the value of women's entrepreneurship endeavours. This calls for governments to do more to help these women entrepreneurs move into the formal economy.

\section{References}

Annink, A., L. den Dulk and B. Steijn (2015), "Work-family state support for the self-employed across Europe," Journal of Entrepreneurship and Public Policy, Vol. 4, No. 2, pp. 187-208, doi: 10.1108/jepp-01-2014-0006.

Barnard, C. and A. Blackham (2015), "The implementation of Directive 2010/41 on the application of the principle of equal treatment between men and women engaged in an activity in a self-employed capacity", European Network of Legal Experts in Gender Equality, http://ec.europa.eu/justice/genderequality/files/your rights/self employed en.pdf.

Bosma, N. (2014), "The Global Entrepreneurship Monitor (GEM) and its impact on entrepreneurship research," Foundations and Trends in Entrepreneurship, Vol. 9, No. 2, pp. 143-248.

European Commission (2017a), "Peer Review in Social Protection and Social Inclusion: Synthesis Report - Reconciling Family Life and Entrepreneurship," DG Employment, Social Affairs and Inclusion, available at: http://ec.europa.eu/social/BlobServlet?docld=18095\&langld=en.

García-Calvente, Y. and M. Ruiz-Garijo (2014), "Una lectura de género de las medidas fiscales en España a favor del emprendimiento ¿Una nueva oportunidad perdida?”, Nueva Fiscalidad, Vol 2, pp. 59-102.

Gatewood, E., P. Greene and P. Thulin (2015), "Sweden and the United States: Differing Entrepreneurial Conditions Require Different Policies", Jubilee Publication of the Swedish Entrepreneurship Forum.

Gong, X., R. Breunig and A. King (2010), "How responsive is female labour supply to child care costs? New Australian estimates", IZA Discussion paper no. 5119.

Kalb, G. (2009), "Children, labour supply and child care: challenges for empirical analysis", Australian Economic Review, Vol. 42, No. 3, pp. 276-299. 
Kossek, E., S. Lewis, and L. Hammer (2010), "Work—life initiatives and organizational change: Overcoming mixed messages to move from the margin to the mainstream", Human Relations, Vol. 63, No. 1, pp. 3-19.

OECD/EU (2019), The Missing Entrepreneurs 2019: Policies for Inclusive Entrepreneurship, OECD Publishing, Paris, https://doi.org/10.1787/3ed84801-en.

Strohmeyer, R., V. Tonoyan and R. Leicht (2006), "Part-time self-employment and the reconciliation of family and work: Do institutions matter? 19-country study (summary)", Frontiers of Entrepreneurship Research, Vol. 26 (11), Article 5. 


\title{
Kenya
}

\author{
By Anne W. Kamau, University of Nairobi
}

Winnie V. Mitullah, University of Nairobi

\section{Background}

In Kenya, the informal economy employs approximately $80 \%$ of the workforce and is a key contributor to job creation (Okungu and Mclntyre, 2019). The sector includes micro and small enterprises (MSEs). Recognising the role that the informal sector plays in Kenya's economic growth since the mid-1960s, the government has introduced policies to support the MSEs' growth and development (KNBS, 2016). Lead policies include:

- Sessional Paper No. 1 of 1986 on Economic Management for Renewed Growth which emphasised the role of the informal sector in job creation and provided policy directions for credit provision, import substitution and promoting local industries, as well as the formation of an inter-ministerial small-scale enterprise unit and taskforce to review informal sector policies (King, 1986);

- Sessional Paper No. 2 of 1992 on Small Enterprises and Jua Kali; and

- Sessional Paper No. 2 of 2005 on Development of Micro and Small Enterprises (SMEs) for Wealth and Employment Creation for Poverty Reduction which emphasised the importance of SMEs in job creation.

These policies have shaped Kenya's economic path with an emphasis on SMEs. This resulted in the enactment of the Micro and Small Enterprises (MSE) Act No. 55 of 2012, the first comprehensive MSE law in Kenya. The Act established the MSE Authority with the mandate of supporting the development of new enterprises, improving access to capital, and strengthening the co-ordination and technological advancement of MSEs. The authority also provides for women's representation in its main governance body, thus promoting gender mainstreaming in all MSE activities and programmes.

\section{Policy issue: Access to social protection}

Kenya has many policies supporting MSEs. However, policies have deficits in addressing social protection. This undermines the performance of all enterprises, however, the lack of social protection disproportionately affects women entrepreneurs who constitute $48 \%$ of MSEs and the largest proportion of vulnerable informal sector workers (Rockfeller, 2013). Whereas Kenya's social protection policy seeks to extend social security to all workers and their dependents (ROK, 2011), most informal sector workers remain outside of social protection coverage (OECD, 2017). The limited social protection provision among these workers is attributed to the voluntary nature of Kenya's social protection programmes for the informal employed workers, inadequate programme funding, high cost of premiums, low awareness about social protection schemes, and non-consolidated payment mechanisms (ILO, 2019). Regulations determining enrolment and eligibility to access benefits, as well as restrictive contribution payment options further limit women's participation in the programmes. The lack of social security coverage affects informal sector workers' ability to invest in business expansion and growth because saved incomes and profits are often used to respond to shocks. Likewise, women are often forced to divert their meagre incomes to the care economy. Their businesses are further undermined when they cannot operate because of undertaking household and caring roles.

The Kenya government has made efforts to promote women's access to business finances. An example is the Women Enterprise Fund which was enacted into law in 2019 as the consolidated Uwezo Fund (RoK, 2019). The Uwezo Fund ${ }^{1}$ enables women, youth and persons with disability to access finance to promote businesses and enterprises, and to take advantage of the $30 \%$ government procurement provision. 
Similarly, private formal agencies, including microfinance institutions, savings and credit co-operatives (SACCOs) and mobile money services provide loans to enhance women's financial inclusion in business (Finaccess, 2019). However, these efforts do not include social protection. Hence, women entrepreneurs cannot take full advantage of the funding sources for investments because they often use the loans to address immediate needs and shocks rather than investing in business growth.

Many women remain in the informal economy due to conflicting financial, time and family demands. They have competing demands that require them to provide for their families, including meeting the health and education needs of their children (Kamau et al., 2018). Hence, they make small inaugural investments in their businesses. Providing social protection coverage to informal sector workers can cushion women from social and economic shocks and poverty (Barrientos, 2010).

\section{Conclusions and recommendations}

Current social protection policies do not adequately cushion a large number of women entrepreneurs from shocks. A significant number of women entrepreneurs operate in the informal sector. Most women rely on informal saving mechanisms to support their social security and welfare needs (Kamau et al., 2018). It is important for the Government of Kenya to address social and economic policies that hinder women's enterprise growth, and to enhance provision of adequate social protection measures.

\section{Recommendations for Kenya}

- Provide support for child care, business skills and capital for business development to improve the low and slow growth of women-owned businesses.

- Ensure social protection for women entrepreneurs to cushion their businesses from economic shocks and stress.

- Address policy and institutional barriers impacting women entrepreneurs' access to existing social protection programmes and benefits.

\section{References}

Barrientos, A. (2010), "Social protection and poverty: Poverty reduction and policy regimes", Thematic Paper, Social Policy and Development, No. 42, United Nations Research Institute for Social Development (NRISD), Geneva.

Finaccess, (2019). Finaccess Household Survey: Access, Usage, Quality, Impact. Central Bank of Kenya, Kenya National Bureau of Statistics and FSD Kenya, Nairobi, https://www.centralbank.go.ke/wp-content/uploads/2019/04/2019-FinAcces-Report.pdf.

ILO (2019), A quantum leap for gender equality: For a better future of work for all. International Labour Organisation, Geneva.

Kamau A, P. Kamau, D. Muia, H. Baiya and J. Ndung'u (2018), "Bridging entrepreneurial gender gap through social protection among women small scale traders in Kenya" in S. Yousafzai, A. Fayolle, A. Lindgreen, C. Henry, S. Saeed and S. Sheikh (eds.), Women's Entrepreneurship and the Myth of Underperformance, Edward Elgar Publishing, Cheltenham.

King, K. (1986), "An evaluation of research and policies on informal sector employment in developing countries", PHREE Background Paper Series, Education and Employment Division Population and Human Resources Department of the World Bank.

KNBS (2016), "Micro, Small and Medium Establishment (MSME) Survey: Basic Report", Kenya National Bureau of Statistics, Nairobi. 
OECD (2017), Social Protection in East Africa: Harnessing the Future, OECD Publishing, Paris, https://doi.org/10.1787/9789264274228-en.

Okungu V., and D. McIntyre (2019), "Does the informal sector in Kenya have financial potential to sustainably prepay for health care? Implications for financing universal health coverage in low-income settings" Health Systems \& Reform, Vol. 5, No. 2, pp. 145-157, doi: 10.1080/23288604.2019.1583492.

Rockfeller Foundation (2013), "Health vulnerabilities of informal workers", Rockfeller Foundation, https://www.rockefellerfoundation.org/report/health-vulnerabilities-of-informal-workers/.

ROK (2019), The Kenya Uwezo Fund Bill, 2019, Kenya Gazette Supplement National Assembly Bills, Government Printer, Nairobi, http://kenyalaw.org/kl/fileadmin/pdfdownloads/bills/2019/KenyaUwezoFundBill2019.PDF.

ROK (2011), Kenya National Social Protection Policy, Republic of Kenya, Ministry of Gender, Children and Social Development, Nairobi.

\section{Note}

${ }^{1}$ About Uwezo fund, http://www.uwezo.go.ke/about-uwezo-fund. 


\section{Pakistan}

By Shumaila Yousafzai, Cardiff University

Shandana Sheikh, Cardiff University

\section{Background}

The participation of women in the labour market of Pakistan is below most similar economies (Population Census, 2017). As of 2019 , the labour force participation rate of women is $22 \%$, compared to $82 \%$ for men (World Bank, 2020). Disparities in labour market participation are attributed to gender inequality, where Pakistan ranks 151 out of 153 countries with respect to gender disparities (Global Gender Gap Report, 2020). Furthermore, only one quarter of women with university degrees work outside the home, reflecting a loss of economic productivity (Asian Development Bank, 2016).

In support of the United Nations Sustainable Development Agenda of 2030, Pakistan has introduced policies to facilitate inclusive economic growth and development, including promoting entrepreneurship and small business ownership as mechanisms to boost women's economic participation (Asian Development Bank, 2018). The Government of Pakistan, for example, has established the Small and Medium Enterprise Development Agency (SMEDA), ${ }^{1}$ Women Chamber of Commerce and Industry $(\mathrm{WCCl})^{2}$ and the Women Development Department (WDD). ${ }^{3}$ Interventions to support women entrepreneurs' access to capital include the First Women's Bank Limited (FWBL) and Pakistan Poverty Alleviation Fund (PPAF).

Article 34 of the 1973 Constitution of Pakistan states that women shall be given full participation in all spheres of life. Beyond national policies and programmes, the Convention on the Elimination of All Forms of Discrimination against Women (CEDAW) represents an international commitment to address gender discrimination and ensure women's social or economic rights. Agreements with international financial institutions and structural adjustments promote investment in human development to facilitate women's economic participation (UNDP, 2015). The Trade Organisations Ordinance of 2006 required all regional chambers to induct women on to the board of directors and to facilitate the creation of women's chambers of commerce (Center for International Private Enterprise, 2011).

Despite such interventions, women's entrepreneurship remains among the lowest in the world. The Global Entrepreneurship Monitor estimates that only $1.7 \%$ of women are involved in starting a business or managing one that is less than 42 months old (i.e. total early-stage entrepreneurial activity rate) relative to about $5.5 \%$ of men. Overall, Pakistan ranks 49 out of 50 countries (Global Entrepreneurship Monitor, 2020). Further, women in Pakistan are $60 \%$ less likely to consider business opportunities compared to male counterparts and only $34 \%$ of women perceive themselves as capable of starting a business (Global Entrepreneurship Monitor, 2012). Low self-perceptions of entrepreneurial capability reflect a weak entrepreneurial ecosystem. The Global Entrepreneurship Index (GEI, 2018: pp. 3), for example, ranks Pakistan 120 among 127 economies with respect to the health of the entrepreneurship ecosystem: "The GEI measures both the quality of entrepreneurship and the extent and depth of the supporting entrepreneurial ecosystem."

\section{Policy issue: Weak regulatory institutions}

Hindering the participation of women in the formal economy is a weak institutional ecosystem. Regulatory barriers include discrimination and limited access to financial capital, lack of small business support policies, stringent start-up processes, and the absence of family and social care policies. The normative environment entails a complex interplay of socio-cultural and religious norms that confine women to the 
home and restrict their participation in commercial activities. Patriarchal norms and values position women as less capable than men.

Gender discrimination begins in early childhood, where girls are often treated as inferior to boys, and deprived of the basic rights to education, nutrition, and access to economic and social activities. Gendered practices discourage women's mobility and limit interactions with men and boys, reflecting independence as a central tenet in women's lives (Roomi and Harrison, 2010). Moreover, norms of Purdah (the veil) and Izzat (honour) guide women's behaviour and choices and define prevailing gender roles in society. Resultantly, women are expected to perform domestic responsibilities, while men are considered to be responsible for providing for the family (Roomi, 2008; Roomi and Parrot, 2010).

Regulatory barriers, norms and cultural traditions are diffused in institutional and constitutional policies, resulting in discriminatory practices that limit women's engagement in the development and growth of society (Goheer, 2003; Leadership for Environment and Development, 2012). It is a dishonour for men to engage in household or family care, which are viewed as the responsibility of women. The perception of a woman being confined to domestic (unpaid) work, for example, influences maternity, paternity and child care policies. Resultantly, women bear the double jeopardy of home/family care and business responsibilities, wherein priority is given to domestic, unpaid work (Roomi, 2008; Roomi et al., 2018).

The majority of working women are engaged in agriculture, including livestock and dairy farming. On average, women spend 3 to 5 hours per day on livestock related activities, such as cleaning animals and sheds, feeding, collecting fodder, milk processing, manuring, etc. When women engage in entrepreneurial activities, most participate in sectors characterised as crowded and low growth, such as petty food production, beauty and health services, and jewellery making. (Hamdani, 2002). When women are entrepreneurial, their efforts are not recognised due to the invisibility of work confined to space in the home.

In addition to assumed gender roles, norms influence women's access to resources. For example, women retain 3\% of the small and medium business loans advanced by the State Bank of Pakistan (Najam, 2020). Compared to $87 \%$ of men, $19 \%$ of women have access to microfinance loans. Differences are, in part, due to discriminatory lending practices, perceptions that women are less credit worthy, and women's limited collateral. Certain banks require guarantor signatures of the woman applicant's husband or father.

\section{Conclusions and recommendations}

Pakistan utilises less than $40 \%$ of its human resources, leading to weak economic growth (World Bank, 2019). An increase in women's labour force and economic participation will increase Pakistan's GDP by $30 \%$ (IMF, 2018). To this end, investment in women's entrepreneurship is critical. This entails actions to strengthen the entrepreneurial ecosystem, including: increasing awareness about women entrepreneurs; disseminating information about start-up support; and alleviating regulatory and normative constraints that challenge women entrepreneurs. Apart from "one-off" initiatives, there is no coherent policy framework to promote women's entrepreneurship in Pakistan. Recommendations to increase women's entrepreneurial activities and to strengthen Pakistan's social and economic growth follow. 


\section{Recommendations for Pakistan}

- Create gender-aware entrepreneurial ecosystems. Design and implement policies and programmes to support women entrepreneurs, including less stringent regulatory practices (e.g. start-up registrations) and non-discriminatory financing practices, provisions for child-care support and entrepreneurship education, training and skill-building to enhance self-perceptions among women about entrepreneurship as a viable career choice.

- Establish a conducive normative environment for women entrepreneurs. There remains a need to change mind sets about gender and occupational roles, through increased awareness of the benefits of women working outside the home.

- Celebrate the success of women entrepreneurs. Private and public organisations should work together to celebrate the achievements of women entrepreneurs including through financial support for conferences and avenues for professional development and forums, campaigns to promote a positive image of women entrepreneurs and their contribution, and promotion of Pakistani women entrepreneurs at international, national and regional level through print and digital media.

- Support national networks of women entrepreneurs. This could facilitate exchanges of ideas and lead to collaboration opportunities and enable women entrepreneurs to expand their networks, showcase their achievements to peers, and facilitate access to customers.

\section{References}

Asian Development Bank (ADB, 2018), "Strategy 2030. Achieving a Prosperous, Inclusive, Resilient, and Sustainable Asia and the Pacific", https://www.adb.org/sites/default/files/institutionaldocument/435391/strategy-2030-main-document.pdf (accessed on 12 June 2020).

Asian Development Bank (ADB) Briefs (2016), "Policy brief on female labour force participation in Pakistan", https://www.adb.org/sites/default/files/publication/209661/female-labor-force-participationpakistan.pdf (accessed on 10 June 2020).

Global Entrepreneurship Index (GEDI) (2018), "2018 Global Entrepreneurship Index", https://thegedi.org/2018-global-entrepreneurship-index (accessed on 10 July 2019).

Global Entrepreneurship Monitor (2020), "Global Entrepreneurship Monitor 2019/2020 Global Report", https://www.gemconsortium.org/report (accessed on 13 July 2020).

Global Entrepreneurship Monitor (2012), "Economy profile: Pakistan", https://www.gemconsortium.org/country-profile/95 (accessed on 12 July 2019).

Pakistan Bureau of Statistics (2017), "Population Census 2017," http://www.pbs.gov.pk/content/population-census (accessed on 9 July 2019).

Roomi, M. A., S. Rehman and C. Henry (2018), “Exploring the normative context for women's entrepreneurship in Pakistan: A critical analysis, International Journal of Gender and Entrepreneurship, Vol. 10, No.2, pp.158-180.

Roomi, M. A. and P. Harrison (2010), "Behind the Veil, Women's Capacity Building and Enterprise Development in Pakistan", International Journal of Gender and Entrepreneurship, Vol. 53, No. 9, pp. 526-572.

Roomi, M.A. and G. Parrott (2008), "Barriers to development and progression of women entrepreneurs in Pakistan”, The Journal of Entrepreneurship, Vol. 17, pp. 59-72.

UNDP (2015), “Work for Human Development, Human Development Report 2015”, New York: UNDP, 
http://hdr.undp.org/sites/default/files/2015 human development report.pdf (accessed on 8 July 2019).

World Bank (2020), "Labour force participation rate",

https://data.worldbank.org/indicator/SL.TLF.CACT.MA.ZS?locations=PK (accessed on 26 July 2020).

World Bank (2019), "Pakistan @ 100: Shaping the Future",

https://www.worldbank.org/en/region/sar/publication/pakistan100-shaping-the-future. Accessed on 1006-2020.

World Economic Forum (2020), "Global Gender Gap Report 2020”, http://www3.weforum.org/docs/WEF GGGR 2020.pdf.

\section{Notes}

1 SMEDA aims to provide an enabling business environment and support services to small and medium enterprises in Pakistan. It undertakes different intervention projects independently as well as with local/ international partners for complementing each other's efforts in reaching out for Women Entrepreneurs in Pakistan.

$2 \mathrm{WCCl}$ is a chamber that works for economic empowerment of women in Pakistan, particularly those involved in business activity.

${ }^{3}$ WDD was established to provide an enabling environment for women in Pakistan and promote their development in business. 


\section{Sri Lanka}

By Nadeera Ranabahu, University of Canterbury

\section{Background}

Sri Lanka's National Policy Framework for Small and Medium-Sized Enterprise (SME) Development (2015) has a limited focus on gender. The policy vision is "to create a significant number of globally competitive, dynamic, innovative, technologically-driven, eco-friendly and sustainable SMEs that contribute greatly to the national economic development" (Ministry of Industry and Commerce: Sri Lanka, 2015). The mission of the National SME Policy is to stimulate growth of SMEs. In 2016, an action plan was developed to implement the National SME Policy by the Ministry of Industry and Commerce in collaboration with other key government institutions (Ministry of Industry and Commerce: Sri Lanka, 2016). These two documents - the National SME Policy and the action plan - stress that women's entrepreneurship is a policy area in need of attention, alongside green growth, sustainability, creating industrial villages, and SME cluster development. Nevertheless, of the six policy intervention areas identified in Sri Lanka's policy documents, ${ }^{1}$ only three include activities to enhance women's entrepreneurship. These three areas are: enabling environment, entrepreneurial culture and skill development, and access to finance. There is, however, evidence of gender-specific challenges in other policy areas such as access to markets and technology, and innovation (Women's Chamber of Commerce and Industry, 2015). Despite this, explicit reference to activities that support women-led SMEs include only: 1) strengthening women's chambers of commerce and rewarding women entrepreneurs, 2) developing special training programmes targeted toward women, and 3 ) providing concessionary bank loans.

From a feminist perspective, the limited policy focus on women raises the question of whether SME policies have missed an opportunity to address the gender gap in the Sri Lankan context. Sri Lanka, for example, has a 0.680 score in the Gender Gap Index, and is ranked $102^{\text {th }}$ out of 153 countries (World Economic Forum, 2020). Sri Lanka's labour force participation rate for men is $77.1 \%$ compared to just $38.2 \%$ for women (World Economic Forum, 2020). Women's self-employment statistics are not that different to the overall employment figures, with only one quarter of ventures in Sri Lanka being owned by women (Department of Census and Statistics: Sri Lanka, 2015). Hence, mitigating long-term economic consequences of the gender gap requires public policies - including policies on entrepreneurship - having gender-sensitive practices, structures and norms, and creating a supportive business environment.

\section{Policy issue: Regulatory environment and access to entrepreneurship support}

Sri Lankan women entrepreneurs have limited business support and face institutional challenges when they start and manage their businesses (Women's Chamber of Commerce and Industry, 2015). For example, women lack knowledge on legal rights and protections. They are unaware of the process of registering their titles to land, lack awareness about legal protection for business owners, and are unsure about the process for obtaining trade licenses (Women's Chamber of Commerce and Industry, 2015; United Nations: Sri Lanka, 2015). Fear of compliance with tax and other statutory liabilities further limit women from registering their businesses (Women's Chamber of Commerce and Industry, 2015).

Women, in certain areas of the country, lack property rights. Although general law provides matrimonial property rights to women, the customary Thesawalamai property law, which is the traditional law of the Tamil inhabitants of the Jaffna peninsula, requires women to get the written consent of their husbands when selling, mortgaging or disposing of acquired property (United Nations: Sri Lanka, 2015). This is particularly challenging in a post-war context where husbands are missing or when there is no written evidence such as a death certificate (United Nations: Sri Lanka, 2015). 
In addition, lack of transportation affects women's economic engagement. Due to the lack of adequate transport options, women entrepreneurs find it difficult to travel to business development training programmes in main cities (Attygalle et al., 2014; UNDP, 2016). Lack of safety in public transport, as women often experience harassment (Solotaroff et al., 2017; United Nations: Sri Lanka, 2015), leaves them with limited options. Women are also less likely to own vehicles such as tractors, three-wheelers, and bicycles and usually spend more time and money in transporting materials or finished goods (UNDP, 2016).

Women, especially in rural areas, have limited access to business information. They are highly dependent on their immediate social network and have limited access to markets or external networks (Women's Chamber of Commerce and Industry, 2015). Similarly, women are less likely to be members of a trade association or business chamber (Women's Chamber of Commerce and Industry, 2015). Thus, women business owners are less aware of new initiatives, such as eco-tourism, that provide opportunities for growth in emerging sectors (Solotaroff et al., 2017). Women's lack of access to information and networks also restricts their ability to recognise and take advantage of market needs, market gaps and the demand for products (Women's Chamber of Commerce and Industry, 2015; United Nations: Sri Lanka, 2015).

Regardless of these realities, Sri Lankan policy interventions and activities assume that women, similar to men, would benefit from the overall development of the entrepreneurial eco-system. Hence, although activities are specified in current SME policy documents (i.e. special training programmes, rewarding the best women entrepreneurs, supporting women's chambers of commerce, and providing concessionary bank loans for women) they are not sufficiently holistic, nor are they sufficiently embedded within institutionalised structures and processes to bring about significant change.

\section{Conclusions and recommendations}

The contextually embedded nature of women's entrepreneurship in Sri Lanka suggests that, in order to promote women's business ownership, current policies need to account for normative, regulative and cultural factors. The complex nature of women's entrepreneurship also highlights the need for crosssectoral support structures. More specifically, at regional levels, the overall business environment and support structures available for women entrepreneurs need to be improved. Hence, the following recommendations are provided.

\section{Recommendations for Sri Lanka}

- Provide access for women to legal clinics, community level legal services, awareness programmes on business rights and protections, and legal consultation services in collaboration with national or regional organisations (e.g., women's chambers of commerce, universities).

- Promote women's access to training programmes and entry into rapid-growth sectors by establishing business incubator or accelerator services associated with regionally-based institutions such as Vidatha Resource Centres.

- Promote access to market information, financial literacy and business mentoring support for women entrepreneurs located in remote areas through regionally based institutions (e.g. women's chambers of commerce, Vidatha Resource Centres, and divisional secretariats) and through the use of technology-based solutions. 


\section{References}

Attygalle, K., D. Hirimuthugodage, S. Madurawala, A. Seneratne, A. Wijesinha and C. Edirisinge (2014), "Female entrepreneurship and the role of business development services in promoting small and medium women entrepreneurs in Sri Lanka", The Institute of Policy Studies of Sri Lanka and Oxfam International Sri Lanka, http://www.ips.lk/wp-content/uploads/2017/08/female entrepreneurship.pdf.

Department of Census and Statistics: Sri Lanka (2015), "Non-agricultural economic activities in Sri Lanka: Economic census 2013/2014 (Listing phase)", Ministry of Policy Planning, Economic Affairs, Child Youth and Cultural Affairs, http://www.statistics.gov.lk/Economic/Non\%20agri.pdf.

Ministry of Industry and Commerce: Sri Lanka (2015), "National policy framework for small \& medium enterprise (SME) development", http://www.industry.gov.lk/web/images/pdf/framew eng.pdf.

Ministry of Industry and Commerce: Sri Lanka (2016), "Action plan: National policy framework small \& medium enterprise (SME) development”, http://www.industry.gov.lk/web/images/pdf/gg.pdf.

Women's Chamber of Commerce and Industry: Sri Lanka (2015), "Fostering women's entrepreneurship in the SME sector in Sri Lanka", Policy Advocacy Working Group, http://www.wcicsl.Ik/publications/WCIC\%20Policy\%20Advoacy\%20Working\%20Paper.pdf.

Solotaroff, J. L., G. Joseph and A.T. Kuriakose (2017), “Overview: Getting to work: unlocking women's potential in Sri Lanka's labour force" Directions in development-Countries and regions, World Bank Publishing, Washington DC, https://openknowledge.worldbank.org/handle/10986/28660.

UNDP (2016), "Trade Winds of Change: Women Entrepreneurs on the Rise in South Asia: Background country study-Sri Lanka", https://www.asia-pacific.undp.org/content/rbap/en/home/library/sustainabledevelopment/trade-winds-of-change.html.

United Nations: Sri Lanka (2015), "Mapping of Socio-Economic Support Services to Female Headed Households in the Northern Province of Sri Lanka", United Nations, Colombo, http://lk.one.un.org/wpcontent/uploads/2016/05/Mapping-of-Socio-Economic-Support-Services-to-Female-HeadedHouseholds-in-the-Northern-Province-of-Sri-Lanka.pdf.

World Economic Forum (2020), "Insight report: The global gender gap report 2020", http://www3.weforum.org/docs/WEF GGGR 2020.pdf.

\section{Note}

1 The six priority areas are: enabling environment, technology and innovation, entrepreneurial culture and skills development, access to finance, market facilitation, and research and development. 


\section{Annex A. About Global WEP}

The Global Women's Entrepreneurship Policy Research Project (Global WEP - www.globalwep.org) is a network of established researchers from over 30 counties. Its goal is to examine, internationally, support policies for women's entrepreneurship, and to identify explicit or implicit gender biases within public policies. Global WEP also seeks to identify evidence-based good policies or practices that are potentially beneficial to other countries in supporting women's entrepreneurial activities. Global WEP scholars exchange policy knowledge and share policy data for collective publications and report dissemination. In so doing, Global WEP adds value to extant policy scholarship and informs policy development.

Launched by Professor Colette Henry at the 2014 Diana International Research Symposium in Stockholm, Global WEP is supported by an Executive Team and an International Advisory Panel. Global WEP members comprise researchers from Africa, Asia, Australasia, Europe, North America and South America. In addition to hosting by-invitation and open-door workshops, Global WEP has published internal reports, conference papers, book chapters and peer-reviewed academic journals. Global WEP members have also presented at the Diana International Research Conferences, Institute for Small Business \& Entrepreneurship Conferences, United Nations Conference on Trade and Development (UNCTAD), the T20 conference and OECD seminars. In 2017, for example, the group published a comparative study of women's entrepreneurship policy in 13 countries in the International Journal of Gender and Entrepreneurship (Henry, Orser, Coleman and Foss, 2017). The research was based on analyses of 38 policy/policy-related documents, across Africa, Asia, Australasia, Europe and North America. This 13-country study was followed by more in-depth studies, such as that of Coleman, Henry, Orser, Foss and Welter (2019) in the Journal of Small Business Management. Drawing on institutional and feminist theories, this study provides a critique of policies and programmes to increase women entrepreneurs' access to capital in five economies: Canada, Germany, Ireland, Norway and the USA.

Collectively, the studies reveal that authorship of women's entrepreneurship policy documents is often anonymous, rarely gender-balanced, and sometimes predominately by men. The analyses suggest that many government policies relegate women entrepreneurs to minority or disadvantaged group status, hence restricting access to resources or overtly privileging traditional men-dominated industry sectors. Few policy documents explicitly state a theoretical foundation or rationale for intervention, or describe evidencebased inputs and outcomes to inform future policy development. Many policies appear to be pilot initiatives or ad hoc. When such policies are considered within their national and institutional contexts, there is often evidence of a mismatch between official policies on the one hand, and practices and funded programmes on the other. Accordingly, many women's enterprise, small business, and entrepreneurship policies have made only modest contributions to the economic welfare and security of women.

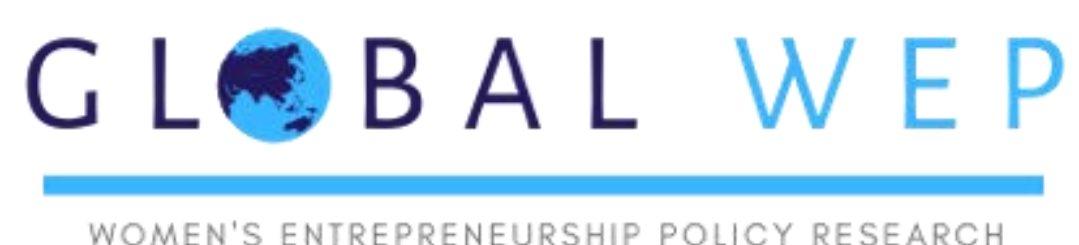

WOMEN'S ENTREPRENEURSHIP POLICY RESEARCH 


\section{OECD Studies on SMEs and Entrepreneurship Entrepreneurship Policies through a Gender Lens}

This publication examines how to strengthen the scope and effectiveness of entrepreneurship policies for women. It examines both dedicated measures for women and ensuring that mainstream policies for all entrepreneurs are appropriate for women. Evidence is offered on the gender gap in entrepreneurship and its causes. At the heart of the report are 27 policy insight notes by leading international experts on the role of public policy in facilitating entrepreneurship by women and how policies can be strengthened. They highlight many long-standing issues related to the scope and effectiveness of women's entrepreneurship policies - many of which have been exacerbated by the COVID-19 pandemic - and point the way to more effective policy. Issues addressed include fostering a gender-sensitive entrepreneurship culture, building entrepreneurship skills for women, improving women's access to financial capital, supporting networks for women entrepreneurs and creating supportive regulatory environments. Issues in the design and delivery of policy support are also addressed. The report was prepared by the OECD in collaboration with members of the Global Women's Entrepreneurship Policy Research Project (Global WEP), a network of established researchers from over 30 counties. 